

Ostaun

lraucary 1913. 





\section{AMERICAN \\ CONSULAR JURISDICTION \\ IN THE ORIENT}

BY

FRANK E. HINCKLEY

Doctor of Philosophy,

Columbia University School of Political Science;

Clerk of the United States Court for China

WASHINGTON, D. C.

W. H. LOWDERMILK AND COMPANY 
COPYRIGHT, 1906, BY FRANK E. HINCKLEY

ALL RIGHTS RESERVED

Published July, 1906

THE MOODY-BARTON PRESS

ELIZABETH, N. J. 


\section{PREFACE}

About ten years ago the conclusion of the treaties for the recognition of the judicial autonomy of Japan brought to public attention the importance and the peculiarities of the system of consular extraterritorial jurisdiction under which Europeans and Americans had been privileged to reside and trade in that country. Still more interest in these privileges and in the protection of foreigners in the Orient, particularly in the interior of Turkey and of China, has since then developed, and with items of news about the political conditions and the commercial exploitation of those regions appearing in the press from day to day, there is a growing desire for better and more fundamental knowledge of the formal relations sustained by the eastern and western governments.

There have been published in England and on the continent a number of excellent works that deal with extraterritoriality and consular jurisdiction. The works to whose authors I am most indebted are: Martens, Das Consularwesen und die Consularjurisdiction im Orient; FéraudGiraud, La juridiction française dans les échelles du Levant et de Barbarie; De Clercq and De Vallat, Guide pratique des consulats; Salem, and others, articles in the Journal du droit international privé et de la jurisprudence comparée and in the Revue de droit internatipnal et de législation comparée; Tarring, British Consular Jurisdiction in the East; Piggott, Exterritoriality; and Hall, The Foreign Powers and Jurisdiction of the British Crown.

There is a valuable chapter on consular jurisdiction in Lawrence's Wheaton. No American author, however, has 
written a special treatise upon foreign jurisdiction except the Hon. E. T. Sheppard, at one time legal adviser to the Japanese government, whose monograph Extraterritoriality, Tokjo, 1871, had the special object of setting forth the reasonableness of the assertion by Japan of the liability of foreigners before their consular courts for infractions of harbor, quarantine and hunting regulations. In 1880 and 1881, Mr. Edward Van Dyck, an American consular clerk at Cairo, Egypt, prepared a report upon the capitulations of the Ottoman Empire since 1150, and the report was published as a senate document. In 188\%, Mr. G. H. Scidmore, an American consular clerk, published at Tokio a small volume of summarized decisions made in cases tried in American consular courts in Japan.

A compilation of treaties, conventions and state papers of the years 1894 to 1904 relating to China and Korea has recently been made under the direction of the Hon. W. W. Rockhill, now minister to China. Mr. E. T. Williams, Chinese secretary to the American legation at Peking, published at Shanghai, in 1904, a volume entitled Recent Chinese Legislation Relating to Commercial, Railway and Mining Enterprises.

Only a few cases decided in the exercise of foreign jurisdiction in the Orient, either British or American, have become available through publication. Some of them are discussed in the English works abore referred to. The development of the jurisdiction in the Levant under various national systems, especially the French, Italian and Greek, and under the international tribunals of Egypt, may be followed in the digests of cases and notes upon them in the Journal du droit international privé, the series of which from 1874 to 1904 is supplied with a general index. Reports of the cases heard in British consular courts in China have for many years been regularly published at Shanghai in the North China Herald and Supreme Court and Consular Gazette. This publication has also contained reports of cases tried in the American and other consular courts; it forms also a very complete and valuable record of public opinion 
upon questions arising in respect to the privileges of extraterritoriality in China. The weekly numbers of the Herald have a semi-annual index. For the use of files of this publication I wish to thank Professor Friedrich Hirth, Dean Lung Professor of Chinese in Columbia University.

But the chief source from which I have obtained material has been the correspondence that has appeared in the annually published Papers Relating to the Foreign Relations of the United States, $18 \% 0$ to 1904 , with the earlier series usually referred to as the Diplomatic Correspondence, 1861 to 1868 , both of which series were provided with a general index in 1899. The general series of congressional documents, from 1789 to date, has also been searched and materials therefrom extensively used. These documents and the diplomatic correspondence and foreign relations papers obviously afford the most detailed and authoritative explanation of what is the nature of the privileges enjoyed by American citizens in oriental countries and what measures of protection experience has shown necessary and effective.

In reading the correspondence contained in these public documents one cannot fail to appreciate the importance and excellence of the services of our diplomatic and consular representatives. To them has been entrusted the elaboration of the American foreign policy and the promotion of American commerce in the Orient, the high character and success of which in the hundred years and more of their existence is generally known. How much our ministers and consuls have individually achieved toward this general result we may know only in the more conspicuous cases, but we may look with pride upon their accumulated contributions to the national honor and welfare.

With two former ministers of the United States, each of them eminently successful in the solution of difficulties pertaining to extraterritorial protection of American citizens and to the administration of justice in the consular courts, it has been my great privilege to consult, the Hon. Oscar S. Straus, minister to Turkey from 1887 to 1889 and again from 1898 to 1900 , and the Hon. George F. Seward, consul 
and consul-general at Shanghai from 1861 to 1876 and minister to China from $18 \% 6$ to 1880 .

I have also received valuable information from merchants and from missionaries, and particularly from the Rev. Henry 0 . Dwight, who for many years resided in Turkey and conducted in behalf of the missionaries what correspondence with the legation at Constantinople the situation required.

In matters pertaining to the rights of citizens under the treaties of extraterritoriality as distinguished from the rights secured to them under the Constitution, I wish gratefully to acknowledge the benefits of conference with Professor J. W. Burgess, Dean of the School of Political Science of Columbia University.

And finally, with exceeding gratitude for his friendly interest and encouragement, with highest admiration of his abilities and attainments, his contributions to legal science and his services in the principal offices in the Department of State, I desire to acknowledge my obligations to Hon. J. B. Moore, Professor of International Law and Diplomacy in Columbia University, whose instruction in previous years, whose continuing counsels and, in the end, whose reading and criticism of the entire manuscript have enabled me to place these results of my research in the present form.

NEw York, June 9, 1906

Note: This edition has been withbeld until the adjournment of the 59th Congress, 1st Session, notable for legislation of great importance, including the Act of April 5, 1906, reorganizing the consular service, and the Act of June 30, 1906, creating a United States court for China. In conformity with these Acts and the Statutes relating to the civil service an Executive Order was issued, June 27, 1906, embodying regulations governing appointments and promotions in the consular service. The leading advocates of this legislation have been Senators Lodge and Spooner and Representatives Robert Adams and Edwin Denby. A number of American citizens familiar with conditions in China, with them Mr. James S. Fearon, Vice-President of the International Banking Corporation, and Mr. Wade Gardner, New York Agent of the Hong Kong and Shanghai Banking Corporation, have 
shown the business necessity, wisdom and timeliness of this legislation.

In all its stages and in its final forms there is evidence of the pre-eminent abilities of the Hon. Secretary of State, Elihu Root, and the guiding mind of His Excellency the President, Theodore Roosevelt.

It has been the author's good fortune to have for reference before closing work on this book an early copy of the government publication of Hon. J. B. Moore's International Law Digest, containing 162 pages on the subject of extraterritorial jurisdiction, being mainly excerpts from and references to manuscript instructions and dispatches on file in the Department of State.

Acknowledgments for recent assistance are gratefully made also to Hon. Robert Bacon, Assistant Secretary of State, to Hon. James B. Scott, Solicitor of the Department of State, to Hon. Wilbur J. Carr, Chief of the Consular Bureau, and to Mr. S. B. Crandall, a law clerk of the Department.

As this book, the work of several years of research, goes to press, an unlooked for and a very happy consummation of the author's long study of the law applicable under American extraterritorial jurisdiction is reached in the receipt of notice that the President has done him the honor to designate him for appointment as clerk of the United States court for China.

The clerk avails himself of this occasion to salute his colleagues, officials of this court, His Honor the Judge, Lebbeus $R$. Wilfley, the Attorney, Adjutant-General Drain, and Mr. Bruce R. Leonard, marshal. 



\section{CONTENTS}

\section{CHAPTER I \\ HISTORIC FORMS OF EXTRATERRITORIALITY}

Spread of the principles of western law in the Orient.... 1

Characteristic features of oriental treaties-a tariff of customs duties and extraterritoriality............. 2

Capitulations of privileges granted to the North Italian cities by Christian rulers in the Levant in the middle

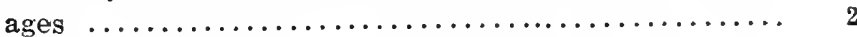

Important additional rights in the capitulations secured from the Saracen and Turkish conquerors of the Levant... 4

Principles of the capitulationis obtained from Turkey by France and other European powers............. 7

Capitulations in favor of France, $1535,1740 \ldots \ldots \ldots \ldots, 10$

Capitulations in favor of England, $1675 \ldots \ldots \ldots \ldots \ldots \ldots, 12$

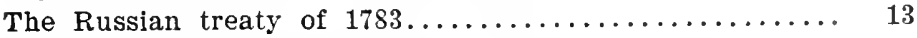

Consular protective powers still exercised in Turkey...... 14

Adaptations of extraterritoriality in China and other countries of the Far East..................... 15

Privileges established by usage and under most-favored. nation clauses of treaties.................... 16

\section{CHAPTER II}

\section{THE UNITED STATES ORIENTAL TREATIES}

Treaties with the Barbary States, Maskat, Zanzibar and Persia .............................. 19

Negotiation of the treaty of 1830 with the Ottoman Porte.. 20 Interpretation of Article IV of the Turkish treaty of 1830.. 23 Resemblance of Article IV to provisions of treaties be

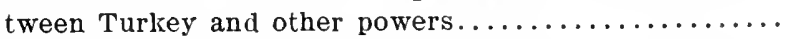

Existing practice of the European powers with respect to

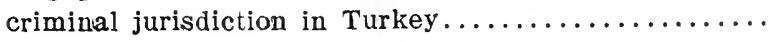


Letters of American consuls describing the practice of approximately the same date as the American treaty.. Later treaties with Turkey................... 29 Treaties with China of $1844,1858,1880$ and $1903 \ldots \ldots \ldots \ldots$ 31

Treaties with Japan of $1854,1857,1858$ and $1894 \ldots \ldots \ldots 35$

Treaties with Siam, Madagascar, Korea, Borneo, Samoa

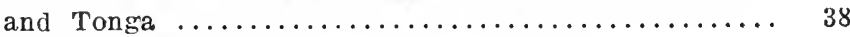

Enumeration of the treaties in force in $1906 \ldots \ldots \ldots \ldots .40$

\section{CHAPTER III}

ACTS OF CONGRESS ESTABLISHING THE SYSTEM OF CONSULAR COURTS

Summary of the present statutes................41-50

Relation of the statutes to the treaties........... 42

Specification of the law to be enforced in the courts... 43

Nature of the regulations to be published by the

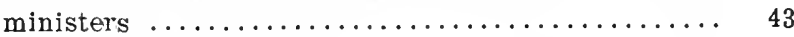

Conferring of judicial authority upon incumbents of certain offices ...................... 45

Settlement of certain cases without resort to litigation.. 46

Jurisdiction of a consul acting alone............. 46

His jurisdiction when assisted by citizen associates on the trial ............................ 47

Jurisdiction of the minister................... 48

Capital offenses and jurisdiction of them.......... 48

Former appeal to the circuit court in California....... 49

Appeals to the United States court for China.......... 50

Authority to execute and manner of executing judg. ments .............................. 50

Official opinions relating to the administration of the system of courts .............................. 50-63

Effect of international law in determining consular judicial authority and extraterritorial privileges.. 50

Significance of the term common law............. 51

Tendency to restrict the contents of regulations to matters of procedure................... 54

Relations of consular judicial officers to theil superiors 56

Consular immunities..................... 59

Relations with officials of the local government...... 59

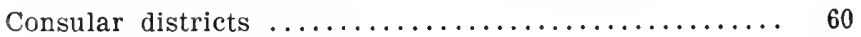

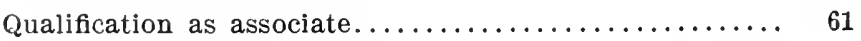

Jurisdiction of the minister................. 62

Cases which have been appealed to the circuit court in California ........................ 63 
PAGE

Constitutionality of the jurisdiction............. 64-9

Forbes v. Scannel, $1859 \ldots \ldots \ldots \ldots \ldots \ldots \ldots \ldots \ldots \ldots$

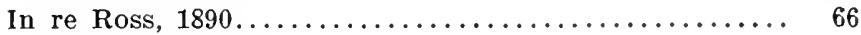

The theory of agency .................... 66

Comparison with jurisdiction in the territories....... 68

Jurisdiction under the power to make treaties......... 68

Principal features of the British and French systems of foreign jurisdiction ..................69-74

The British Foreign Jurisdiction Act of $1890 \ldots \ldots \ldots \ldots .70$

The Orders in Council, their number and scope........ 71

The French system of foreign jurisdiction.......... 72

Origin of municipal organization of foreign settlements and of the office of assessor under French law...... 73

Appellate courts of the British and French systems.... 74

Further development of the American system.......... 74-7

The Davis-O'Connor bill of $1882 \ldots \ldots \ldots \ldots \ldots \ldots$

The Spooner-Denby Act, $1906 \ldots \ldots \ldots \ldots \ldots \ldots \ldots$

\section{CHAPTER IV}

\section{LEGAL RIGHTS UNDER THE JURISDICTION}

\section{I-NATIONALITY}

The scope of the term American nationality.......... 78

Naturalized citizens of Turkish origin............. 79

Restrictions upon Jews in Turkey................. 80

Passports, teskerehs, travel certificates............. 81

Effect of visés of native officials............... 82

Registration ....................... 83

Restriction of the protégé system in the Levant........ 83

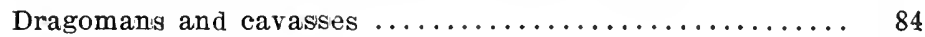

Chinese employees ........................ 85

Native converts ......................... 86

Joint-stock companies.................... 86

Foreigners employed by native governments........... 86

Foreigners employed as seamen on American ships....... 87

Friendly offices toward foreigners are non-jurisdictional.... 88

Results of abusing extraterritorial privileges.......... 89

Effect of prolonged residence abroad............... 90

Expatriation $\ldots \ldots \ldots \ldots \ldots \ldots \ldots \ldots \ldots \ldots \ldots \ldots \ldots \ldots \ldots$

II-THE RULE OF DOMICIL; MARRIAGE; INHERITANCE

Oriental domicil not acquired................. 92

Significance of retaining American domicil........... 92

License to $\operatorname{marry} \ldots \ldots \ldots \ldots \ldots \ldots \ldots \ldots \ldots \ldots \ldots \ldots \ldots$ 
Conisular certification of marriage................ 93

Modes of solemnization....................... 93

Intermarriage with foreigners.................. 94

Divorce .................................. y5

Inheritance of personal property ................ 95

Succession to real property in Turkey and in China....... 96

\section{III-PERSONS ACCUSED OF CRIME}

Petty offenses $\ldots \ldots \ldots \ldots \ldots \ldots \ldots \ldots \ldots \ldots \ldots \ldots \ldots \ldots$

Acts named in the treaties as indictable............. 98

Effect of local police regulations................. 98

Political offenses ......................... 100

Non-neutral acts.......................... 101

Trading in contraband .................... 101

Procedure in the trial of criminal offenders........... 102

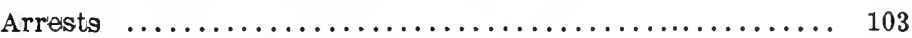

Transfer of offenders in China.................. 104

Consuls have no power to extradite............... 104

Deportation under the British system............... 104

Extradition treaties with Japan and Turkey........... 105

Deportation from Japan..................... 105

Expulsion or exclusion from Turkey............... 106

Place of serving penalty.................... 107

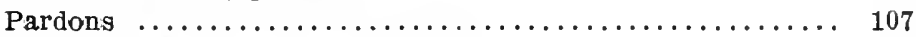

Friendly settlement out of court................ 108

\section{IV-MISSIONARIES}

Importance of rights of missionaries.............. 108

Non-religious policy of the United States............. 110

Religious toleration in Turkey under the treaty of Berlin.. 110

Disallowance of certain Turkish regulations........... 110

Rights of residence in the interior................ 111

Use of dwelling houses as churches and schools......... 111

Domiciliary rights........................ 112

Turkish school regulations.................... 112

Licensing of graduates in medicine............... 113

Turkish regulations upon printing and circulating books.. 114

Protection of native teachers................... 115

Indemnities for mission property destroyed.......... 116

Measures of protection during the Armenian disturbances.. 117

Missions in Persia ....................... 118

Religious toleration under the treaties of 1858 with China.. 118 
The Burlingame treaty of 1868 with China........... 119

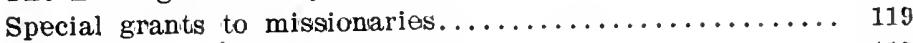

The American treaty of $1903 \ldots \ldots \ldots \ldots \ldots \ldots \ldots \ldots \ldots \ldots$

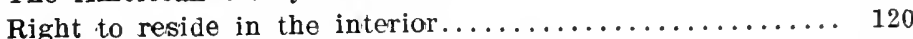

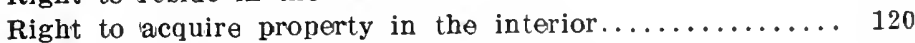

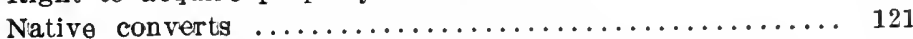

Responisibility of provincial government for protection.... 121

Mr. Rockhill's note........................ 123

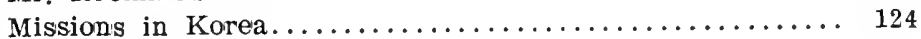

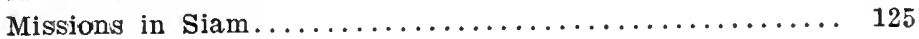

\section{V-REAL PROPERTY}

Land concessions in the open ports of China......... 125

Undesirable methods of acquiring land in the interior.... 126

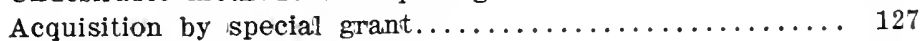

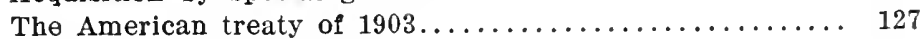

The lex loci applicable...................... 128

Former Turkish claims of jurisdiction of foreigners holding real property ......................... 129

Improvement of Turkish real property law........... 129

Origin of the extension of real property privileges to

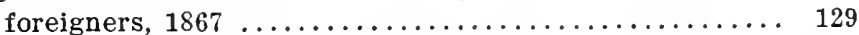

Nature of the real estate rescript of $1867 \ldots \ldots \ldots \ldots \ldots \ldots 130$

The protocol of 1874 between the United States and Turkey I31

Effect of the protocol on jurisdiction............... 132

Rights of expatriated Turks................... 133

Rights of Jews in Palestine................... 133

Right to appeal against unjust action of native courts... 134

Real property privileges in Persia................ 134

\section{VI-TAXATION}

Turkish import and export customs duties............ 134

Prohibition of internal taxes on foreign goods........... 135

Exemption of mission schools from import duties....... 136

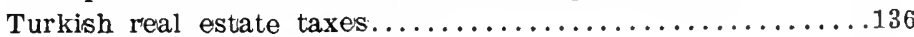

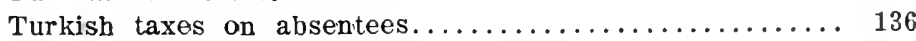

The Chinese Imperial Maritime Customs............ 137

Rules of 1868 for joint investigation of customs disputes.... 137

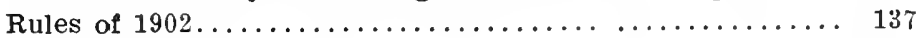

Liabilities under the treaties of 1858 and $1903 \ldots \ldots \ldots \ldots 138$

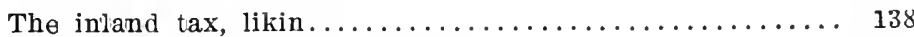

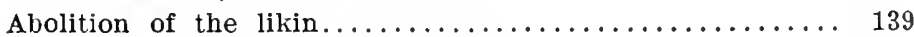

Tax on manufactures by foreigners............... 140 


\section{VII-COMMERCIAL PRIVILEGES}

PAGE

Privileges specified in the treaties................ 140

Chinese legislation in the form of regulations......... 141

Joint-stock companies....................... 142

Rights of manufacturing in China................ 142

Railway and mining concessions................. 143

Non-political American interest in commercial projects.... 144

Effect of the 'open door' policy.................... 144

Monopolies in China......................... 144

Monopolies in Turkey....................... 145

Foreign joint-stock companies in Turkey.......... 145

Postal privileges ........................... 145

Collection of debts......................... 146

Assignment of claims to foreigners ............... 146

Financial conditions......................... 147

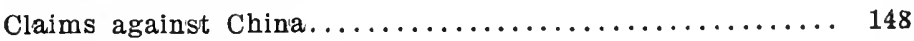

Mr. Hay's telegram of July $3,1900 \ldots \ldots \ldots \ldots \ldots \ldots \ldots \ldots, 149$

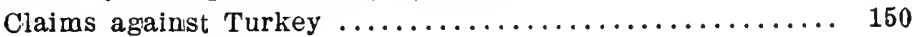

\section{CHAPTER V}

\section{THE INTERNATIONAL TRIBUNALS OF EGYPT; MIXED CASES IN CHINA}

The rule of the defendant's court................ 151

Modifications of the rule in Turkey................ 151

The mixed tribunals of commerce................ 152

The international tribunals of Egypt............. 153-8

History of their establishment................ 154

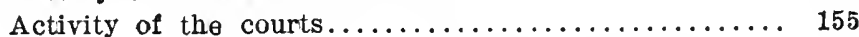

Analysis of the Règlement d'organisation judiciaire.... 156

The crisis of 1880, execution of judgments against Egypt 157

The crisis of 1896, control of the 'caisse de la dette'.. 157

Question of permanence of the courts with other inter. national institutions in Egypt............. 158

Jurisdiction of mixed cases in China...............159-60

The conference of 1879 at Peking................ 159

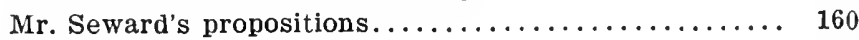

Existing practice in China................. 160

Cases involving foreigners or different nationalities.... 160

Settlement of mixed cases through diplomatic correspond.

ence with the oriental government............. 161

Settlement of a claim against Siam by arbitration....... 162 


\section{CHAPTER VI}

\section{THE FOREIGN MUNICIPALITY OF SHANGHAI}

The organization of foreign communities in China........ 163-7

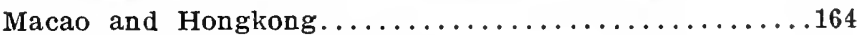

The foreign settlement at Canton.............. 165

A coöperative policy favored by the United States... 165

Separate concessions at Tientsin and Hankow....... 166

The foreign municipality at Shanghai.............167-76

Early impontance of Shanghai............... 167

Municipal organization made permanent in $1854 \ldots \ldots 168$

Description of the municipal organization provided in

the land regulations of $1866 \ldots \ldots \ldots \ldots \ldots \ldots \ldots$. $168-9$

Legal force of the municipal ordinances........ 170

Limitations upon the territorial jurisdiction of China

over the foreign settlement.............. 171

The Chinese or 'mixed' court................ 172

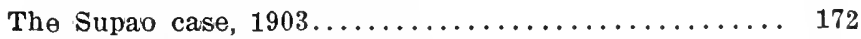

The case of the Japanese spies, $1894 \ldots \ldots \ldots \ldots \ldots \ldots 174$

The desire to preserve the neutrality of Shanghai..... 175

Jurisdiction in the leased areas of North China..........176-7

Retention of the sovereignty of China........... 176

Jurisdiction suspended by the powers, excepting Japan 177

\section{CHAPTER VII}

\section{GROUNDS FOR RELINQUISHING JURISDICTION}

Extension of European sovereignty leading to cessation of

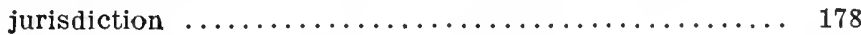

Retention of some native law in European colonies...... 178

Effect of military occupation................... 179

Jurisdiction in European protectorates.............. 180

Jurisdiction in newly independent states............. 182

The establishment of judicial autonomy in Japan. . . . . . . 183-8

The embassy of 1872 to America and Europe........ 184

The period of building the modern national government 18

The conferences of 1886 at Tokio.............. 185

Favarable attitude of the United States............ 185

The negotiations with Great Britain............ 186

Effortis of Turkey toward abrogation............... 188

'La question des capitulations' since $1856 \ldots \ldots \ldots \ldots 188$

The arbitration awarding to Greece the retention of extraterritoriality after the war of 1897 with Turkey 189 
PAGE

Present administration of justice in Turkey......... 191

Recent treaty statements of grounds of relinquishing

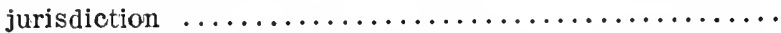

The attitude of the government of China respecting the

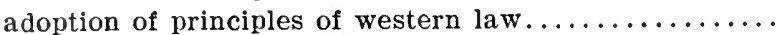

Relinquishment is, as a rule, simultaneous on the part of

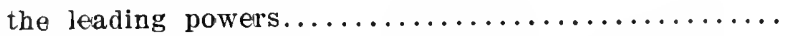

Improved administration of jurisdiction contributes to

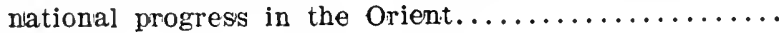

\section{APPENDIX}

I Extraterritorial stipulations of United States treaties..

II United States Revised Statutes, Sections 4083-4130.... 204 III-1-Reorganization of the consular service, Act of

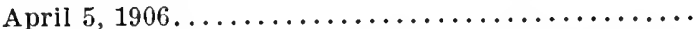

2-United States court for China, Act of June 30, 1906. .

3-Executive Order, June 27, 1906, consular service, regulations governing appointments and promo-

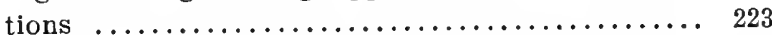

IV-1-Consular court regulations for China, general, 1864. 226

$2-$ Same, summons to absentees, $1881 \ldots \ldots \ldots \ldots \ldots . \ldots \ldots$

3-Same, arrests and renditions, $1897 \ldots \ldots \ldots \ldots \ldots . \ldots \ldots$

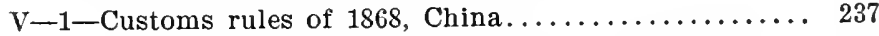

2-Customs Rule I, American-Chinese treaty, 1903.... 240

VI The municipal government of Shanghai.......... 241

VII-1-Rules of procedure for the Court of Consuls, Shang-

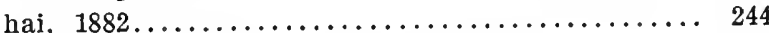

2 -Rules of 1869 , Mixed Court at Shanghai......... 245

3-Same, amendments proposed in $1906 \ldots \ldots \ldots \ldots .247$

4-Rules of 1902, Mixed Courts of the International and French Settlements, Shanghai............ 249

VIII Macdonald $v$. Anderson, Tientsin, 1904........... 250

IX Consular court regulations for Turkey, $1862 \ldots \ldots \ldots 254$

X Portion of Lord Cromer's report on Egypt, 1906..... 267

XI Reference tables:

1 -Consular court regulations................ 270

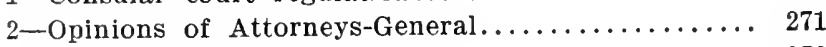

3 -Legations and consulates.................. 272

4 -Open ports of China.................... 273

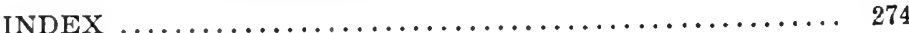


AMERICAN CONSULAR JURISDICTION IN THE ORIENT 

Jnscribed to me wife 

AMERICAN CONSULAR JURISDICTION IN THE ORIENT 



\title{
AMERICAN \\ CONSULAR JURISDICTION \\ IN THE ORIENT
}

\begin{abstract}
I
HISTORIC FORMS OF EXTRATERRITORIALITY
\end{abstract}

The extension of European domination throughout much of the Orient has, in our own day, opened a prospect of wonderful development of eastern peoples in general civilization, in methods of government necessary for protection of life Spread of the principles of western law in the and property, and in conceptions of justice and of the utility and authority of courts of law.

The commercial and political influence of the western powers has spread rapidly; their law can be adopted but slowly. It is in fact the survival of many of the ancient traditions and customs that will make the readjustment to new principles peaceable and permanent. Only one oriental nation, the Japanese, is thus far admitted actually to have assimilated enough of European jurisprudence to entitle its government to exercise full responsibility for the protection of foreigners within its territory. This progress of Japan has no doubt been facilitated by its maritime situation and its more general intercourse with the West. Elsewhere in 
the Orient, and conspicuously in China, national progress has waited upon the opening of the interior waterways and the building of railroads. Until recent years it was uncommon to find foreigners residing or trading anywhere back from the seaboard. In the open ports, as at Shanghai, there were cosmopolitan communities whose mercantile interests it was not difficult to protect. But foreign enterprise and capital now radiate long distances inland. How to regulate the enjoyment of the new franchises and privileges is a serious problem. And what is true of China, with its great rivers open to traffic and its extensive railroad concessions, is in a measure true also of Korea and Siam, Persia, Turkey and Egypt.

Characteristic features of oriental treaties-a tariff of customs duties and extraterritoriality

Capitulations granted to the North Italian and other cities

Heretofore the protection and regulation afforded in the special forms of treaties in the oriental states has sufficed. These treaties have two features distinct from others: first, they stipulate with exceptional detail what shall be the treatment of merchant vessels discharging or loading cargoes, what the customs examinations, and what the customs duties upon the specified imports and exports; secondly-and for this they are distinguished as treaties of extraterritoriality-they stipulate in general that the persons and property of citizens or subjects of the western state, party to the treaty, shall be exempt from the jurisdiction of the courts of the oriental state; that their domicil shall be inviolable; that, except in the act of committing flagrant crime, none of them shall be arrested by native officials; that, if so arrested, they shall be given over to their consul for trial and punishment; and that the consul shall exercise jurisdiction over his nationals, with the right to require the assistance of the local authorities in so doing.

During the two or three centuries before America was discovered, the North Italian cities of Venice, Genoa, Pisa and Florence and other western cities of Marseilles and Barcelona obtained from the Greek Christian rulers at Constantinople and later from their Mohammedan conquerors, numerous charters for the protection of their commerce and for the exemption from the local government of their mer- 
cantile communities residing in the Levant. These charters, being set out in articles or capitula, acquired the name capitulations, a term now generally used to denote treaties with Turkey prior to the nineteenth century.

In 1199 the Emperor Alexius III issued a chrysobulum of privileges conceded to the Venetians. Some of its capitula provided that differences in commercial matters arising between Greeks and Venetians were to be decided in the court of the defendant, but only upon written evidence of contract, and the plaintiff was, moreover, required to give bond to answer a counterclaim. Criminal cases involving persons of both nations, if the offense had caused a popular disturbance or if a Greek official had been implicated, were to be tried before one or another of the chief Greek magistrates, but other offenses, including those committed by Greeks within the quarter of the city set aside for the residence of Venetians, were to be tried and punished under Venetian authority. ${ }^{1}$

A century later, 1304, Emperor Andronicus II granted a privilegium aurea bulla nostra munitum, declaring the Genoa 1304 rights and jurisdiction of the republic of Genoa within his realm. There was to be a separate quarter, a fondicus, or factory for the Genoese in Galata in the northern part of the city of Constantinople. Every individual who was in good faith a Genoese was to be subject only to the jurisdiction of his national authorities, and if it became necessary for the Greek authorities to apprehend a Genoese offender outside of the Genoese quarter, they were at once to render him up to his national authorities in Galata. Likewise Greeks were to be rendered up if taken by the Genoese authorities. The same rules were to apply to a

\footnotetext{
1 Tafel and Thomas, Urkunden zur älteren Handels- und Staatsgeschichte der Republik Venedig, Fontes rerum austriacarum, Zweite Abteilung, Diplomataria et Acta, vol. xii, p. 273, 278. In another place Professor Thomas notes an adaptation of Roman law procedure in civil actions, as provided in the capitulations between Venice and Byzantium of 1199 , and similarly in the treaty between Venice and France of 1207: Gelehrte Anzeigen, Bulletins, München, August 28, 1854, p. $19-28$.
} 
quarter set apart for Genoese in Smyrna, and similarly to all Genoese wherever they might trade on the mainland or among the islands. No injury to a Genoese either in person or property was to remain unpunished, neither was a wrong against a Greek to continue without penalty or satisfaction from the Genoese consular courts. Expeditious execution of judgments was mutually guaranteed. Every Greek or Latin, subject or not to the emperor, and accused of crime toward a Genoese, unless the Greek or Latin should be of a nation or class holding special rights under treaty, was to be tried and summarily punished wherever in the empire he might be taken; and upon its part the government of Genoa was in like manner to deal with offending Genoese. ${ }^{1}$

Privileges in Syria granted by Chrlstian princes during the crusades

Changes introduced under the Saracen caliphates

The trade with eastern nations received a great impulse at the time of the crusades. Religious motives hastened the conflict, but the demand for oriental merchandise then sustained and later confirmed the European states in preventing the various Mohammedan races from closing or dominating their routes of commerce to and from the East. When the maritime cities of the South of Europe engaged to carry the armies of crusaders beyond the sea, they demanded in return large commercial privileges in the conquered territories, the island of Cyprus and the coasts of Syria. The consuls of the city of Marseilles, located at Tyre and Acre, though obliged to take oaths of fidelity to the Christian princes, were granted jurisdiction over their fellow-citizens excepting for felonious crimes. The oath of fidelity of the Venetian consul at Tyre bound him to render justice according to the usages and customs of the port, and if these were indeterminate, then upon principles of natural justice.

Elsewhere beyond the Mediterranean, in Egypt and along the Barbary coasts, whither an earlier crusade of Moslems against Christian Europe had made its way, and where, until the rise of the Turks, lay the very center of Arabian civilization, the pursuit of commerce had also led the cities of Italy

\footnotetext{
${ }^{1}$ Historiae patriae monumenta, Liber iurium reipublicae Genuensis, vol. 1i., p. 440 .
} 
to make their consular establishments. Tolerated only for the sake of a lucrative trade, the European merchants were, as unbelievers, held to be vile enemies. They ventured among a people fired with the most terrible religious hatred and always bent upon making them a prey. They were forbidden, on penalty of confiscation of goods, of slavery and of death, to deal with the Moslems; yet from the twelfth century the city republics, Pisa, Venice, Genoa and Florence, traded extensively at both Tunis and Alexandria.

The capitulations secured by Pisa in 1154 to protect her community at Alexandria contained the rule that no citizen of Pisa should be held by the government of Egypt for the wrong-doing or the debt of another citizen, and that no Pisan ship should be detained in port to exact payment of a debt. Here are new features, not found in the capitulations obtained from the Greek Christian emperors of Constantinople. Both import and export duties are fixed at ten and twelve per cent., to be collected by Egyptian officials, and the officials are to be restrained from extortions. The capitulations are sealed under vows of their great sanctity and permanence, yet they are renewed frequently, almost from year to year and upon the payment of handsome tribute. Later capitulations, particularly those in force at Tunis, introduced the extreme rule of holding the consul responsible for the wrong-doing of his fellow-citizens, and the capitulations of 1445 respecting rights of Florentines and Pisans at Tunis placed all civil and commercial causes arising between Florentines, or between other Europeans and Florentines, under the jurisdiction of the chief Tunisian customs official. ${ }^{1}$

More marked innovations in the principles of the capitulations resulted from the overturning of the Saracen caliphate in Egypt by a less civilized and extremely fanatic race of Mohammedans, namely, the Turks. The Turkish hordes, after spreading destruction in Syria and Egypt, turned

\footnotetext{
1 Amari, I diplomi arabi del archivio florentino, Florence, 1863-7, was the first work to demonstrate the importance of the capitulations secured by the Italian city republles in the Levant.
}

Changes resulting from Turkish onquests 
northward into Asia Minor. They overran several ancient states, despoiled the Byzantine empire, captured Constantinople, and, following up the Danube, thrust a conquering arm far into Europe. With the sword raised against all Christian nations they rushed onward unchecked by any such crushing blows as their fellow-religionists had met with when they invaded Europe by way of Spain and France seven hundred years before. But their advance was restrained both by an appreciation of their greatest prize, the imperial city, and by the serious difficulties of keeping in subjection the ancient Christian nations dwelling in the regions reaching from eastern Armenia across to the city itself, center of the Greek church. Upon every side the Turks were surrounded by a world at enmity with Islam, a dar-el-harbi, as their religious hatred described it; and if there was occasional respite from this enmity, the onslaught was more furious in times of religious fervor. ${ }^{1}$

Hazards of trade in the Levant

The Sultans regarded the capitulations only as temporary truces. Merchants from the wealthy cities of Venice and Genoa, pleading forbearance and favor, sought to preserve some of the great commerce of Byzantium, what was then the world's commerce between the East and the West. But to the Moslem a Christian's property was the property of no one; a European merchant was a villain, a ghiaour or 'dog.' Italian and French ships were everywhere the prey of pirates: their seamen were taken as slaves, the merchants themselves, usually looking after the transportation of their wares in person, were seized upon for ransom, and their goods were liberated only when they made enormous gifts.

The foreign consuls were long regarded as mere hostages responsible for whatever charges might be brought against other Christians. Frequently they were thrown into prison. The ambassadors of western states, 'earnestly imploring' the Sublime Porte, came bearing precious gifts, 'les presens acoutumées, - so read the English capitulations of 1675. In

1 von Hammer, Geschichte des Osmanischen Reiches, books 13-20, Pesth, 1827; Pears, The Destruction of the Greek Empire and the Story of the Capture of Constantinople by the Turks, London, 1903, chap. $x x$. 
fact the earlier capitulations ordinarily opened with adulation of His Majesty the Sultan. The same English capitulations say: "Moy qui suis le puissant Seigneur des Seigneurs du Adulations of the sultans monde, dont le nom est formidable sur Terre, Distributeur de toutes les Couronnes de l'Univers, Sultan Mahomet Han .. cette Haute Porte Imperiale qui est le refuge des Princes du monde, et la retraite des Rois de tout l'Univers." Similarly extravagant language appears in the French capitulations of 1740 ; but the Russian capitulations of 1783 have only the expression 'la sublime Porte,' and the American treaty of 1830 uses the same form.

Contempt like this for the Christian powers was also long fostered among the Barbary rulers by the payment of tributes and ransoms. The United States was the first to put an end to it as well as to the piracies of the western Mediterranean; but clearing the sea of pirates by force of arms was more readily accomplished than causing the Mohammedan rulers to treat western merchants and missionaries with justice when they took up their residence in Mohammedan countries.

In spite of the hostility and contempt displayed by the governing class of the principal Mohammedan state toward Christians from the fifteenth to the end of the eighteenth century, it was in this period that the powers of western Europe secured the series of capitulations recognizing their extraterritorial rights. Although the protection and jurisdiction exercised by European consuls in Turkey in our own times is not fundamentally different from the system developed by the Italian city republics at Byzantium, the principal terms of the modern treaties are derived from the more important of the later capitulations, such as those in favor of France of 1535, 1604, 1673 and 1740; of England of 1583 and 1675 ; of Holland of 1680 ; of Austria of 1718; and of Russia of 1783 .

The first western power to succeed to the commercial prestige of the Italian cities was France. At the epoch of the crusades close relations existed between the French crown and the Christian principalities of Syria. When these had

The principal capitulations to be examIned
Privileges socured by Marsellies in Egypt 
fallen before the forces of the great Saladin, he required of the city of Pisa that the commercial privileges enjoyed by the Pisans in Egypt should in no wise be shared with the merchants of France. But the cities of Marseilles and Barcelona, coöperating in commercial enterprises along the north coast of Africa, made themselves, in the course of the next century, foremost in the trade with Egypt, so that other European nations availed themselves of the protection of the French flag. Here is the origin of the predominating influence of France in the Levant, a predominance at its height from the sixteenth to the nineteenth centuries, indicated in the treaties and usages and in common parlance by the designation of Europeans and Americans of whatever nationality as Franks. The French commerce in the Levant, at first controlled by merchant associations and by the municipal government of Marseilles and other southern cities, did not come fully under royal control until the seventeenth century and the time of Colbert, but long before then it was placed under royal protection.

Capitulations in favor of France,
Under Francis I this commerce led to the adoption of a foreign policy which may be counted the first landmark in the development of the famous 'eastern question.' The Turks had made war upon Austria, they were overrunning Hungary and they coveted the city of Naples. Being jealous of the power of the Emperor Charles V, the French king cast his influence on the side of the Ottoman Porte. In recognition of this friendly assistance the Sultan Suleiman entered into a commercial treaty with Francis I, a treaty drawn as modern treaties are drawn and signed by the plenipotentiaries of the two states. This treaty, which was concluded in 1535, granted to France privileges similar to those guaranteed to the Italian cities in the earlier capitulations. It is, indeed, the earliest of the capitulations obtained by the great powers of Europe from the Ottoman Porte.

The capitulations of 1535 were to remain in force during the lives of the two sovereigns. The subjects of either might travel, trade or reside anywhere within the territory of the other. The French consuls at Constantinople and elsewhere 
in Turkey were to be furnished with evidence of their offi- Privlcial standing, and were to have the same powers and privi- cured to leges that French consuls had exercised at Alexandria. No ${ }_{1535}$ Turkish judge, cadi, soubachi, or other Turkish official was to hear, judge or decide legal actions, either civil or criminal, of whatever nature, between subjects of the King of France, even if they should ask it, and if a Turkish judge should render a decision, his judgment was to be of no effect. If the consul should request assistance in the enforcement of his decisions, it was to be given. Mixed civil cases were to be tried in Turkish courts, but only in the presence of the French consular dragoman and upon written evidence of contract, sealed before a notary public. The subjects of France might not be summoned, molested or tried without the written consent of a French consular officer. Mixed criminal cases were not to be tried by the ordinary officers of the law among the Turks, but were at once to be tried before the principal state official of the Sultan or his substitute, and before him the evidence of the French witnesses was to be heard upon equal terms with the evidence of Turks. Under no circumstances could a difference of religion be made the cause for arrest or trial before a Turkish judge. No one but a party to a contract and his surety could be held responsible for its fulfilment. Subsequent articles contain prohibitions against the taking of slaves and the aiding 'or'abetting of pirates, as well as provisions for the protection of property in shipwreck, the transfer of inherited property through the consul, and freedom from all taxes except customs, unless the period of residence in Turkey should extend beyond ten years. Finally, it was agreed that the Pope, the King of England and the King of Scotland might enter into the same treaty by exchange of ratifications; and the treaty was to be confirmed in due form and published throughout the jurisdictions of the two sovereigns. ${ }^{1}$

${ }^{1}$ De Testa, Recueil des traités de la Porte Ottomane, Parls, 1874, vol. 1 , p. 15. 
France, 1569, 1604 and 1679

Capitulations of 1740

granted

to

France

Many repetitions and a few variations occur in the French capitulations of the next two centuries. Those of 1569 stipulated that in mixed cases the French consul should promptly send his dragoman to the court so that the trial should not be delayed or frustrated. Those of 1604 placed under French jurisdiction the Christian subjects of the Sultan who were solely engaged in foreign trade, and gave the trial and punishment of pirates, even Turks, into the hands of the French, if originally taken by the French. ${ }^{1}$ Those of 1673, complaining that the Turkish courts had not received evidence of Christian witnesses and had given judgment upon contracts not in writing, thus assisting in the extortion of money, stipulated that suits for four thousand aspers or more should be brought before the Sublime Porte. ${ }^{2}$

The next important capitulations in favor of France, those of 1740, were secured after the King of France had rendered assistance to the Sultan of Turkey in another grave crisis in eastern affairs. Territory bordering upon the Black Sea had been acquired by Russia, and, upon pretext that the Russian people inhabiting the valleys of the Don and Dnieper could in no other way be protected from Tartar raids, the Czar evidently intended to acquire more territory by conquest. Russia fcund an ally in Austria, whose safety necessitated crowding back the Turks along the Danube. The war was most fierce. The Austrians were repulsed and their city of Belgrade reduced. Russia, however, succeeded in occupying territory about the Sea of Azof. France intervened. Then, because of the value of this intervention, the Ottoman Porte established still more firmly the commercial prestige of the French in his dominions. A very skilful diplomat, Villeneuve, secured the capitulations of 1740 , the most complete and explicit of all the capitulations, a treaty whose terms are followed in other leading treaties and upon which rests the modern law of France and in some measure the law of

1 De Testa, Traités de la Porte Ottomane, vol. î, p. 141.

3 Noradounghian, Recueil d'actes internationaux de l'Empire Ottoman, Paris, 1897, vol. i, p. 136. 
other governments regulating the administration of consular courts in the Levant.

The capitulations of 1740 consist of eighty-five articles. At least half of them are repetitions word for word of earlier capitulations; several provisions are repeated in various forms as if to leave no mistake that such and such privi- tions of leges were granted; other stipulations are entirely new. The number of dragomans and interpreters of the French ambassador and consuls was to be limited. Turkish subjects appointed to act as French consuls could not thereby exempt themselves from Turkish jurisdiction. If a Frank should of his own will become a convert to Mohammedanism, he would be required to give notice to his consul and by this act he would relinquish his nationality. All Franks were to carry passports. The Christian religious societies established at the holy places were not to be molested and were to have their own independent jurisdiction. Mixed cases between aliens were not to be heard before Turkish courts unless both parties were willing. The expenses of nixed cases involving both Franks and Turks were fixed at two per cent. of the value recovered in the action. Cases once decided were not to be reopened or heard upon appeal unless the consul consented.

The fifteenth article is of the following purport: If a crime had been committed by one French subject upon anCriminal jurisđicother, the trial was to be lield before the French minister or consul, according to their national law, and without the interference of any Turkish official. And the sixty-fifth article provided that if a Frenchman or protégé of France committed a crime to which Turkish law was applicable, the Turkish judges or other officials should not proceed in the matter except in the presence of the French ambassador or consuls or their substitutes. ${ }^{1}$

The earliest of the capitulations secured by England were those of 1580. The French opposed the granting of these privileges and succeeded in making them of no effect, so that

Additional under capitulation

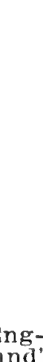

\footnotetext{
${ }^{3}$ Féraud-Giraud, De la juridiction française dans les échelles du Levant et de Barbarie, Paris, 1871, vol. i, p. 113.
} 
the English remained as in the past under French protection. But in the seventeenth century, when, on account of a conflicting policy toward Austria, the French influence with the Porte waned, the English obtained independent privileges; and these capitulations of 1675 , renewed in 1809, remain the basis of British foreign jurisdiction in Turkey to-day.

What the The English secured for themselves and for the Holcapitu-

landers liberty to trade and reside anywhere in the Turkish dominions, including Egypt and the Barbary States. ${ }^{1}$ The earlier capitulations in favor of the Venetians and the French were renewed and made applicable to the English. Freedom from the capitation tax was guaranteed. Consuls might be located wherever the trade demanded and they were in no particular to be subject to Turkish jurisdiction nor were their houses to be placed under seal of court. The number of interpreters to be employed was limited, and no interpreter was to be arrested or tried by Turkish authorities. Disputes of whatever nature in which Englishmen alone were concerned were justiciable solely by the English authorities. No Englishman could be summoned to appear in a civil action in a Turkish court except upon written consent of his consul, and the court could not proceed to trial without the presence of a consular officer. No evidence could be received in such an action contrary to the expressions of a contract under the seal of a cadi or notary. No Englishman could be held for the debt of another except upon written evidence of his being a surety. No judgments, past or future, made contrary to the capitulations were to have force. A crime committed by an Englishman, if it amounted to a felony, was to be tried in a Turkish court, but only in the presence of the consular dragoman. Englishmen who had been wrongfully tried and imprisoned were to be released. Under no pretext were Englishmen to be seized

2 The Netherlanders obtained capitulations for themselves in 1612 , yet remained under either French or English protection until 1741 , when by their own law, they were forbidden to take protection under any other flag than that of the Netherlands; Martens, Das Consularwesen und tie Consularjurisdiction im Orient. Berlin, 1874, p. 229. 
and held in slavery. English ships were not to be molested on the ground of carrying goods of an enemy, a pretext under which piracy had been flagrant. Some of the provisions, particularly those referring to the retention of ancient usages, were repeated many times, and the reasons for the frequent renewal of and additions to the capitulations were inserted. ${ }^{1}$

Taking up the capitulations obtained by Austria and Russia, we find several differences from the French and English instruments. These differences might be expected in view of the contiguity of the countries and the frequent wars by which Turkish territory had been lost either to Russia or to states newly set up in the valley of the Danube. Of all questions none would seem more important than that of determining nationality, yet the Austrian capitulations of 1718 and the Russian of 1783 are silent upon the subject. Notwithstanding Austria's suzerainty over Venice, the Venetians kept their ancient privileges under their own capitulations until 1866, and as of old the chief Venetian officer or consul bore the distinctive title of bailo. The consuls of Austria, unless by special arrangement, were to be stationed only where consuls of other states were located. Turkey was to possess the right of having shabbenders or consuls in Austria, but these consuls were not invested with special judicial functions. Austrians in Turkey were not under any circumstances to be put in prison except by order of their own national authorities.

The difficulties between Turkey and Russia, originating in The Rusthe Tartar disturbances north of the Black Sea, were increased by the fact that Russia had become the protector of the Greek church, whose metropolitan had formerly been established at Constantinople, and whose adherents in and about that city were very numerous. The initiative in the cultivation of closer commercial relations was taken by Rus-

\footnotetext{
1 Dumont, Corps universel diplomatique du droit des gens, Amsterdam, 1781 and later, vol. vii., pt. 1, p. 297, gives a text in French much longer than that in English given in the British and Foreign State Papers, vol. 1, pt. 1, p. 747.
}

Austrian and Veneprivileges sian treaty of $17 \mathrm{S3}$ 
sia. Turkey not only refused to send an ambassador to Moscow, but when first consenting to trade with the Russians, declined to grant them specific privileges. Until late in the eighteenth century the Russians were not allowed to trade along the coasts of the Black Sea, except in Turkish ships. The treaty of peace of Kutschuk Kainardji of 1794 granted to Russia all the privileges of trade enjoyed by the French and English in the Turkish dominions. The capitulations of 1783 are notable for their very clear statement of the customary extraterritorial privileges of Europeans in Turkey. To mention but one distinctive feature: in order that Ottoman subjects in the pursuit of their commerce might not leave Turkey without the knowledge of the Ottoman government, they were not to receive permits from the Russian legation to go to Russia except upon formal request from the Porte; reciprocally, Russian subjects were not to enter the Turkish dominions without the necessary Turkish firmans. Nothing was said of stationing Turkish consuls in Russia, but Russia guaranteed full and equal justice to Ottoman subjects before the courts of law.

Survival sular jurisdiction in

From the beginning of the nineteenth century the term capitulation was less frequently applied to the international agreements to which Turkey was one of the contracting parties and the term treaty took the place of the term capitulation. The treaties of the third decade of that century, among them the treaty with the United States, are not spoken of as capitulations, although they preserre the essential character of the capitulations. Whether the change of terminology indicates a new conception of these arrangements as bilateral rather than unilateral is not of practical significance. The fact is that consular protection and jurisdiction in Turkey is fundamentally the same as it was in the fifteenth century. For all the intercourse of Turks with western Europeans and for all the international relations into which the Turkish gorernment has been admitted there has been no development of judicial institutions, no building up of governmental protective responsibility which other powers have regarded as sufficient to warrant them in with- 
drawing their jurisdiction; and there seems to be no immediate prospect of progress in Turkey that may bring about such a concession of Turkish judicial autonomy. ${ }^{1}$

Turning to extraterritorality in the countries of Eastern Asia, it is first to be observed that the whole history of the jurisdiction is comprised within the last seventy years. Moreover, the religions of the Far East have had no Adapta tions of extraterritoriality in China direct bearing upon the rights of foreigners sojourning in those countries. Corresponding to the nominal suzerainty of the Ottoman Porte over the Barbary States and Egypt, there was once the question of Chinese suzerainty over Korea to the north and Annam to the south; and the question of the control of the Porte over the local governors in Turkey has been paralleled in the apparently ill-defined authority of the provincial taotais in China.

The territorial sovereignty of China was not impaired until the Opium War, which ended in 18t2, and the real significance of the grant of extraterritoriality then made was not felt by China until the treaties of 1858 .

Between the treaties with Turkey and those with China there is this fundamental difference, that the treaties with China contain no reference to privileges resting upon customs and usages. With the exception of restricted privileges enjoyed by the Russian caravans in extreme northwestern China many years before the western European treaties with China were made, these treaties marked the very beginning of extraterritorial jurisdiction in that country. The earlier practice had, in fact, been just the opposite of that stipulated in the treaties. But the customary rights of foreigners in Turkey are so considerable and of so long standing that no attempt to reduce all of them to explicit written statement has been made. And yet, if the jurisdiction in China continues for a long period, a group of customs will ineritably grow up and in time be claimed as rights additional to those stipulated in the treaties."

'Odysseus (pseud.), Turkey in Europe, London, 1900, chap. iii. iv, v.

2 With reference to the growth of usages in the exercise of consular 
Privileges established by usage

Mostfavored. nation treatment

Another fundamental distinction is that in the Mohammedan states foreigners of whatever Christian nation, whether subjects of treaty powers or not, are by immemorial custom permitted to enjoy extraterritorial privileges through the system of consular protection, while in the states of the Far East, especially as these privileges are grounded upon differences more of government than of religion, no such system has become established.

Whether the ancient usages, so frequently mentioned and confirmed in the Turkish capitulations, included essential rights, not described in the texts of earlier documents, cannot be shown. In fact there is much difference in the provisions of the capitulations and even some divergence upon important points. But the perpetuation of ancient usages plainly implies that no sudden and arbitrary act of a native official, overturning a long recognized right of aliens in Turkey, shall be tolerated; neither shall an alien or his consul assume privileges beyond those customary. Consular jurisdiction in the Levant is the result of an evolution persisting through many centuries, and its various adaptations from epoch to epoch have only confirmed the fundamental principles of the general system.

In a sense an effect corresponding to that of the term usages in the Turkish capitulations and treaties is produred by the langruage of the Chinese and other treaties referring to the most-favored-nation. The most-favored-nation clauses have effected an enlargement of the jurisdiction to the fullest extent granted in any of the treaties and hare made the privileges practically uniform for all the treaty powers. Thus a narrower grant of jurisdiction, coupled with a most-

Jurisdiction in Japan, Viscount Aoki, Minister of Foreign Affairs, said in 1900: "The actual stipulations contained in Japan's ancient Treaties are not so directly responsible for that incompatibility [with constitutional government in Japan] as are the privileges and immunities which are destitute of any express warrant for their existence, but which have been claimed upon the supposition-a supposition which the Imperial Government do not sharethat they are essential to the proper and complete enjoyment of guaranteed rights." Parliamentary Papers, vol. xcvi, Japan No. 1 . p. 52 . 
favored-nation clause, has been enlarged thereby to the extent of the grant in a later or even in an earlier treaty with some other power. In this way the treaty of 1869 between Austria-Hungary and Japan, in the negotiation of which the Japanese later believed that Great Britain was especially interested, virtually created an enlargement of the jurisdictional privileges of all the treaty-powers beyond those granted in the treaties of 1858 . In one notable instance the entire foreign jurisdiction rests upon nothing more than a mostfavored-nation clause, namely, British jurisdiction in Persia, which rests upon a clause in the British treaty with Persia of $185 \%$, giving to Great Britain the benefit of other treaties, such as the very full treaty between Russia and Persia of $1828 .^{1}$

In its historical beginnings the grant of extraterritorial jurisdiction was not considered a disparagement to the sovereignty of the state that granted it. The conception of sovereignty as territorial is relatively modern, and extraterritoriality is a surviving form of the earlier prevailing Extratorlality as a disparagement, a modern concepconception that it was the duty of a sovereign to protect those who swore their personal allegiance to him. This principle of personal or national allegiance continued to operate much longer in oriental states than it did in the states of western Europe. It was usually by rendering military service or by the payment of tribute that various divisions of the oriental nation recognized the sovereignty of the central power, and the territorial borders of an oriental state extended as widely as its rulers conld compel the giving of tribute or of military service. In this way the rulers in the Levant thought of the European traders as sufficiently acknowledging their sovereignty when they paid the taxes at the seaport. So also in China and Japan, the Europeans, when they had paid taxes on their trade, were regarded as having given satisfactory recognition of the sovereigns of those countries. In the early years of western intercourse

1 Hertslet, Persian Treaties, London, 1891, p. 19, 128; Piggott, Exterritoriality, London, 1892 , p. 66. 
with countries of the Far East there was less pride on the part of oriental sovereigns in preserving their territorial jurisdiction. China, indeed, appears to have desired to retain territorial jurisdiction, Japan to have yielded for the sake of conrenience and to aroid entanglement with foreign powers. There existed in Turkey before the middle of the nineteenth century, no thought of extraterritoriality as a disparagement to the sovereignty of the Sultans, and in 1875 Turkey made a consular convention with Persia in which extraterritoriality in its fullest form was mutnally granted. ${ }^{1}$

Exception to non-reciprocity

The ordinary non-reciprocity as between western and eastern states in respect to extraterritoriality is also not without exceptions. Spain conceded extraterritorial privileges to Turkish subjeets by a treaty of September 14, 1782 , which was confirmed by a treaty of March 2, 1840; and by a treaty with Tripoli of September 10, 178t, the same privileges were extended to subjects of Tripoli in Spain. ${ }^{2}$ Great Britain, by a treaty with Turkey of January 5, 1809, agreed that Turkish consuls or shabbenders in Halta should have similar privileges and immunities to those granted to English consuls resident in the Ottoman Dominions'; yet whether a Turkish consul in Malta ever exercised extraterritorial jurisdiction there is no eridence.

${ }^{1}$ Hertslet, Persian Treaties, p. 179 ; at p. 184 , the text of a vizierlal letter explanatory of the details of the convention is given. See also notes to cases involving Persians tried in Turkey, Journal du droit international privé et de la jurisprudence comparée, 1900 , p. $401,44 i$, and 1901, p. 591 .

a Cantillo, Tratados, Madrid, 1843, p. 559, 590, 887; Riquelme, Derecho publico internacional, Madrid, 1849, book 1, p. 391 . Riquelme thinks that in practice the subjects of Morocco also had extraterritorial privileges. Spain maintained special courts for jurisdiction of all foreigners.

Brit. and For. State Papers, vol. 1, pt. 1, p. 71, Art. VIII. 


\section{THE UNITED STATES ORIENTAL TREATIES}

Privileges of exemption from native jurisdiction in the East have been a subject of treaty negotiation on the part of the United States, first, with the group of Mohammedan countries mainly situated south and east of the Mediterranean Sea; secondly, and generally at a later period, with China, Siam, Japan, Korea and the native govermments of islands in the South Pacific Ocean. The foreign jurisdiction of the United States has thus been established in one oriental country after another, following the eastward expansion of our commerce. ${ }^{1}$

While the commissioners who had signed the treaty of peace of $1 \% 82$ with Great Britain were still in Paris, they were authorized by Congress to negotiate with the rulers of the Barbary States or to empower substitutes to negotiate. Through a substitute, Thomas Barclay, the earliest of these treaties, that of 1787 with Morocco, was obtained. Other early treaties with North African states were negotiated by consuls under instructions issued to Colonel David Humphreys, minister to Portugal. The second treaty with Tripoli, that of 1805 , was primarily a treaty of peace, and the treaty of 1815 with Algiers resulted immediately from the appearance of Commodore Decatur's fleet before the city. ${ }^{2}$

${ }_{1}^{1}$ Portions of the treaties are printed infra. Appendix I.

2 In the making of these early treaties the feature of extraterritorlality appears not to have been thought exceptionally important. The treaties resemble those of England, France and Holland of the seventeenth century, which were published previous to the Amerlcan negotiations in Dumont, Corps universel diplomatique du drolt des gens, Amsterdam, 1766 and later, and Wenck, Corfx juris gentium, Leipsic, 1781 and later. 
Of these extraterritorial treaties there are still in force only the Morocco treaty of 1836 and the Tripoli treaty of 1805. The Tunis treaty of 1797 was nominally in force until March 15, 190t, when the United States, by special treaty, recognized the protectorate over Tunis which France had established in 1881. ${ }^{1}$ In 1830 jurisdiction in Algiers ceased with the military occupation of that country by France which subsequently dereloped into annexation. ${ }^{2}$ The protégé system in Morocco was regulated by a convention signed by several powers at Madrid in $1880 .^{3}$ In $190 t$ Great Britain recognized the predominating influence of France in Morocco. Similarly, Italian influence tends to predominate in Tripoli.

Maskat and Zanzlbar

A treaty with Maskat, another Mohammedan state, was negotiated in 1833 by Edmund Roberts, a sea captain, commissioned by President Jackson. Maskat then extended from the Persian Gulf southward along the coasts of Africa, but to-day it comprises only a small area at the mouth of that Gulf. Having gained independence from Maskat, the rulers of the island of Zanzibar and the adjacent mainland made a treaty of extraterritoriality with the United States in 1886. Since then, excepting a few mainland ports leased to Italy, Zanzibar has become a British protectorate, and by convention of February 5, 1905, with Great Britain extraterritoriality therein has been relinquished by the United States. ${ }^{4}$

Persia The treaty with Persia of 1856 was negotiated at Constantinople by the American minister to Turkey, Carroll Spence. It is one of the few treaties with Persia that directly grant extraterritorial privileges. The British privileges of extraterritoriality, for instance, rest solely upon a most-favored-nation clause. ${ }^{5}$

The treaty of 1830 with the Ottoman Porte was nego-

${ }^{1}$ Compilation of Treaties in Force, Sen. Doc. 318, p. 949 (vol. 37) 58th Cong., 2 d Sess.

${ }^{2}$ Cf. Mahoney $\because$. U. S., 10 Wall. (U. S.) 62.

- Brit. and For. State Papers, vol. 71, p. 639-44.

- Archives diplomatiques, 1905 , pt. iji, p. 262-4.

${ }^{5}$ Supra. p. 17. 
tiated under most adverse circumstances and the particulars of its negotiation possess special interest on account of their bearing upon the long disputed question of interpreting the fourth article of the treaty. Civil strife was distracting the country and Constantinople was already the center of the conflicting policies that eventually brought about the Crimean War. American trade had been protecting itself by paying a heavy 'consulate duty' to the English Levant Company and the exclusive commercial privileges of England, France and the Italian States, enjoyed by them for fully three centuries preceding, were being threatened with infringements through the opening of the Black Sea, which Russia and other powers had secured in 1827 and later. Russia was friendly to the United States throughout the negotiation of the treaty, but the American agents deemed it best to approach the Porte without the good offices of any European power. The first commissioner of the United States, Luther Bradish of New York, when asked at an official interview in 1820 under the protection of what European power he had placed himself, replied, "That of the Sublime Porte." This exhibition of confidence gratified the Turkish officials exceedingly, yet they withheld themselves from negotiating.

The agents sent by this government in 1820, 1823 and 1825 obtained copies of treaties between Turkey and England, France and Venice, and they also secured advantages in trade at Smyrna. In 1828 President Adams, having received an invitation from the Turkish authorities to resume negotiations, issued a joint commission to Captain W. M. Crane, commander of the American squadron in the Mediterranean, and David Offley, who had been consul at Smyrna for several years. Yet even under these auspices no treaty was negotiated.

Finally, in 1829, President Jackson, believing the time opportune, appointed Captain James Biddle, David Offley and Charles Rhind commissioners with full power jointly and severally to negotiate with the Porte. They were furnished with copies of the capitulations in favor of France of 1740 and of the treaty of $182 \%$ between Turkey and Spain. They

The commission sent by President Jackson 
were instructed, with special emphasis, to obtain absolute protection for Ameriean citizens and the largest privileges for their trade, including those recently granted to the leading European powers, namely, narigation of the Black Sea and a tariff of customs duties of not more than three per cent.; and they were enjoined to use particular care to obtain aceurate translations of documents, so that misunderstandings might not arise from obscure language in the treaty, a source, it was believed, from which difficulties between Turkey and other states had previously arisen. Mr. Rhind was to proceed alone to Constantinople, and when the success of the negotiations was beyond doubt, he was to be joined by his fellow-commissioners. ${ }^{1}$

With peculiar preeautions of secrecy Mr. Rhind embarked at Philadelphia at night and sailed to the island of Minorea, where he joined Captain Biddle in the frigate Jaz'a. On December 26, 1829, when the frigate dropped anchor below the citadel of Smyrna, Mr. Offley came on board and stated that the nature of their mission was already perfectly well known in that city. Nevertheless, Mr. Rhind cautiously made his way to Constantinople.

Gradually he prepared to meet the Turkish officials under favorable circumstances. With the assistance of the dragoman Navoni, he put his proposed address into the French and Turkish languages. When he came before two of the chief dignitaries, he gave them, upon request, a transcript of the address in Turkish. Four days later it was learned that the Sultan, upon reading it, had directed the Reis Effendi to close with the Americans to their satisfaction. The Reis Effendi now formally received the commissioner, sending horses to the landing place and giving publicity to the affair as for the audience of an ambassador of a friendly power. After the usual ceremnny of pipes and coffee, the Reis Effendi inquired whether the commissioner wished to modify his proposals, and being assured in the negative, he said

${ }^{1}$ Ho. Ex. Doc. 250 (including the two documents under this number, the first designated as "Treas. Dept.," p. 1-95, the second as "Executive," p. 1-27), (vol. 6) $22 d$ Cong., 1st Sess.; see also Sen. Ex. Doc. 200, p. 1-215, (rol. 3), 25th Cong.. 3d Sess. 
that the Sublime Porte, desirous of giving a proof of friendly feeling toward the United Statcs, had ordered a treaty to be drawn up in strict conformity with the one Mr. Rhind had submitted and that he then had the honor of presenting it. In a subsequent conference, Mr. Rhind's report continues, the Reis Effendi "signed and sealed the treaty in Turkish, and I did the same with the French translation; and we exchanged them."

The original treaty in Turkish, signed by the Reis Effendi, Docuwas transmitted to Washington together with a copy of the before treaty in French, as signed by the American commissioners, senate and with other French and English translations. The 'Turkish original and French and English translations were sent to the Senate. The document actually voted upon and approved by the Senate was one of the English translations, and with the Turkish text it forms part of President Jackson's ratification. ${ }^{1}$

Before the ratifications were exchanged at Constantinople, the American chargé d'affaires, Commodore David Ratifications Porter, received complaints that the French translation returned by him was not in perfect accord with the Turkish original, a circumstance purely the result of mistranslation. To obviate the difficulty he signed a paper which purported to accept the Turkish instrument without reserve of any word. This signed paper was itself in the Turkish language. A translation of it, sent to Washington, did not call forth disapproval. ${ }^{2}$

It was nearly forty years after its negotiation that correspondence arose between the two governments regarding the interpretation of Article IV of the treaty. In 1868 two Americans, alleged to have been concerned in an affray in Syria, were arrested and imprisoned by the local authorities. The American minister, E. Joy Morris, demanded their re-

1 Notes written by J. H. Haswell supplementary to the notes of J. C. B. Davis, Treaty Volume of 1889, p. 1369.

2 Jour. Ex. Proceedings of Senate, vol. 4, p. 126;8 Debates in Congress, 2186-98. The expenses incurred for gifts at the time of exchanging the ratifications were very large; Ho. Ex. Doc. 303 (vol. 6), 22d Cong., 1st Sess. 
lease upon the strength of that part of the English text of Article IV, as published in the United States statutes, which reads:

Citizens of the United States of America, quietly pursuing their commerce, and not being charged or convicted of any crime or offence, shall not be molested; and even when they may have committed some offence they shall not be arrested and put in prison, by the local authorities, but they shall be tried by their Minister or Consul, and punished according to their offence, fol. lowing, in this respect, the usage observed towards other Franks. ${ }^{1}$

In reply, the Turkish Minister of Foreign Affairs pronounced the English text of Article IV a defective translation of the Turkish original, which he claimed to be the standard, and declared that the words of the translation pertaining to exemption of American offenders from arrest and trial by the local authorities were not to be found in the Turkish text of the articie.

The American government, while admitting itself to be bound by the Turkish text, declined to concede the correctness of the construction put upon it by the Ottoman authorities, and took steps to obtain an exact translation.

Trans-

No translation was found to contain the word 'arrested' or the word 'tried,' yet every translation contained phrases stipulating that American citizens should not be imprisoned in a Turkish prison, but should be punished through the instrumentality of their minister or consul. Thus it appeared that if the Turkish authorities should assume to arrest, the treaty forbade them to imprison, and if they should undertake to try the offender, the treaty denied them the right to execute the penalty. Such an alternation of procedure was regarded confused and impracticable. ${ }^{2}$

The Ottoman Porte did not, however, admit the accuracy of any of the translations obtained by the United States, and when invited to present a translation of its own, postponed doing so for many years. It was not until 1888 that,

18 Stat. at Large, 409.

Correspondence of $1880-1$, quoted in For. Rel. 1885, p. 892. 
under authority of his government, Mavroyeni Bey, Turkish minister at Washington, presented the following translation:

Les citoyens Américains vaquant paisiblement aux affaires de leur commerce ne seront point molestés sans motif tant qu'ils n'auront pas commis quelque délit ou quelque faute; même en cas de culpabilité, ils ne seront pas emprisonnés par les juges et les agents de la sûrété, mais ils seront punis par les soins de leur ministre et consul à l'instar de ce qui se pratique à l'êgard des autres Francs. ${ }^{2}$

Upon the basis of this official translation the Secretary of State, Mr. Blaine, claimed that the inhibition upon Turkey not to imprison and the provision that offenders should be punished under the direction of their minister or consul necessarily involved the right to try; but as a concession to a friendly power, he offered, while retaining the right to punish, to yield the right of trial and to accept the procedure followed in the case of certain European powers under which alien offenders have been tried in courts of the local government, the dragoman of the legation being present. ${ }^{2}$ Yet, with surprising indifference to the reasonableness and value of these concessions, Mavroyeni Bey at once proceeded to contest the right to punish, though his own translation admitted this right in the clearest terms; and he argued that the final clause, in referring to the usages observed toward other Franks, formed a restriction upon all the foregoing provisions, and that when the treaty was made, these usages did not include the right to punish, any exceptions to the contrary existing only 'abusively.'

But, answered the American authorities, the final clause,

\footnotetext{
${ }^{1}$ For. Rel. 1900, p. 917. The translation of this French version given by the Department of State is as follows: "American citizens peaceably attending to matters of commerce shall not be molested without cause so long as they shall not have committed any offense or fault. Even in case of culpability they shall not be imprisoned by the Judges and police agents, but they shall be punished through the agency of their ministers and consuls, according to the practice observed in regard to other Franks."
}

'For. Rel. 1900, p. 915-9.

Proposal to accept the treatment accorded to the European powers 
being general in its terms, was simply explanatory and could in no wise restrict the specific grant of the right to punish. Whatever the usages observed toward other Franks when the treaty was negotiated or at any other time, the Turkish government had definitely conceded the exemption of American offenders from imprisonment by Turkish officials and had expressly given to their ministers and consuls the exclusive right to execute criminal sentences.

Resemblance of Article IV to provi. eions of treaties between Turkey and other powers

Existing practice

There are three treaties of later date than the American treaty that contain expressions equivalent to those of Article IV : the treaty with Belgium, August 3, 1838; ${ }^{\mathbf{1}}$ with the Hanse Cities, May 18, 1839 $;^{2}$ and with Portugal, March 20, 1843. ${ }^{3}$ The Turkish goverument has not contested the accuracy of these texts. If the French texts are the originals, or if they are eorrect translations of Turkish originals, they establish the fact that the Turkish government has at least in terms granted the more extensive jurisdiction and that there was a tendency to make the jurisdiction of the various powers in Turkey entirely uniform. The Russian treaty of September 2-11, 1829,4 provided in its serenth article that subjects of Russia residing in Turkey should be under the exclusive jurisdiction and police control of their minister and consuls; and the code of criminal law of Russia, Article 175, provided that crimes committed by Russians, whether against their fellow-subjects or against other foreigners or Turks, should be under the jurisdiction of the Russian minister and consuls; but in actual practice this jurisdiction has not been regularly exercised. ${ }^{5}$

The existing practice of the various European governments with regard to criminal cases involring their subjects in Turkey had become fully known to the American authorities through correspondence with those gorernments. It

${ }^{1}$ Brit. and For. State Papers, vol. 26, p. 1224.

Ibid., vol. 28, p. 450.

3 Martens, Nouveau receuil générai de traités (Murhara), vol. 5, p. 160.

- Martens, Nouveau receuil, 2d ed., vol. 8, p. 147.

- Martens, Das Consularwesen, p. 470; Hail, Foreign Jurisdiction, p. 13\%, footnote 2, and p. 153, footnote 2. 
was found that ordinarily such cases were left to Turkish jurisdiction, but with the safeguards of immediate notice of arrest, presence of the dragoman at the trial, and, if desired, execution of the penalty under supervision of the national authorities of the accused. With such a system in use, no case of any importance failed to be virtually or actually determined by the minister or consul, and the main benefit of extraterritoriality was thus kept. ${ }^{1}$

The very impossibility of specifying in the treaties the many details of the usages and customs pertaining to extraterritoriality, and the infrequency with which some of them are claimed, have made it difficult at times to establish a right to them. Moreover, the privileges of extraterritoriality in Egypt have been considerably greater than elsewhere in the empire, and occasionally there has been a claim of the right to enjoy in other parts of Turkey the privileges which usage and local law have made peculiar to Egypt. ${ }^{2}$

1 Pradier-Fodére, Droit international public, Paris, 1888, vol. 4, p. 753, after citing the capitulations, says: "On voit par ces textes que la jurldiction n'est expressément et dans la règle accordée aux consuls qu'autant que les actes passibles de répression ont été commis par les nationaux de ces consuls à l'égard d'autres nationaux ou de protégés de l'êtat dont ces consuls dépendent; cependant l'usage général a étendu cette compétence aux cas ou des étrangers s'y trouveraient intéressés, et il est généralement constaté, en ce qui concerne notamment la France, que toutes les fois que les consuls de ce pays ont reclame la faveur de s'emparer de la poursuite dirigée contre un de leurs nationaux ou protégés français prévenu de crime a légard d'un sujet de la Porte, cette faveur leur a été accordée. On peut donc résumer de la maniére suivante la pratique observée sur ce point dans le Levant et les Etats barbaresques d'après les capitulatlons et surtout d'après les usages. S'il s'agit de crimes ou de délits commis par un etranger contre un autre etranger relevant du même consul, c'est ce consul qui est compétent, dans tous les cas; le droit de poursuite et la répression lui appartiennent. Si les crimes ou délits ont été commis par un étranger au préjudice d'un sujet ottoman ou barbaresque, dans la régle l'autorité locale devrait rester chargée de la répression en présence du consul ou de son délégué, mais, en fait, et conformément à l'usage, ces crimes et délits sont le plus généralement soumis à la juridiction étrangère. Que si, enfin, les crimes ou délits ont été commis par un indigène contre un européen ou un américain, en général ils sont jugés par les tribunaux du pays."

2 Gatteschi, Manuale di diritto pubblico e privato ottomano, Alexandria, 1865; appendix relating to Egypt. 
Letters of American consuls describing the practice of approximately the same date as the treaty

Certain earlier correspondence of two American consuls in Turkey explicitly stating the practice in criminal cases as they knew it and as it had no doubt been when the treaty was made, appears not to have been brought to the attention of the American authorities at any time during the long controversy. This is the correspondence of Francis Dainese, consul at Constantinople in 1852, and of John P. Brown, whose career as consul and as dragoman to the legation extended as far back as 1833 .

Mr. Dainese, in describing generally the operation of the treaty, being manifestly without argumentative purpose and unaware that any difference of interpretation might arise, wrote as follows:

In criminal cases between Turks and foreigners, which are tried before the council of police, if the award be adverse to the latter, they are not subject to its execution in Turkey, but are sent, together with the documents relative to the case, to their respective governments for disposal. ${ }^{2}$

Mr. Brown, who was at the time consul-general at Constantinople, having observed that Attorney-General Cushing, in his opinion under date of September 19, 1855, ${ }^{2}$ had assumed that Article IV gave Americans, if charged with criminal offenses, the right to be tried by their consul, wrote a letter with the distinct purpose of showing this belief to be erroneous. $^{3}$ Mr. Brown, speaking of the practice then existing, says that it is true of all foreigners, including Americans, that they are

tried for the commission of crime, whenever their plaintiffs are Ottoman subjects, by the Ottoman courts only, 'in the presence of the American dragoman.' For this purpose the Sublime Porte has established a police court under the minister of police or his assistant, and there are no foreigners among its members.

\footnotetext{
1 Ho. Ex. Doc. 82, p. 192 (vol. 10), 34th Cong., 3d Sess.

27 Opin. Atty-Gen. 502. An opinion had been given by Attorney-General Toucey, January 31, 1849, that the Act of 1848 extended to Turkey in respect to criminal jurisdiction only; 5 Opin. Atty-Gen. 67.

Ho. Ex. Doc. 68, p. 65 (vol. 7), 35th Cong., 2d Sess.
} 
Its decisions are executed by itself in ordinary cases, yet in capital ones, or even when the criminal is condemned to a long imprisonment, it makes him over if so required, to his own legation to be sent to his country for punishment. . . . In the Turkish original the word 'tried' by their minister or consul certainly does not exist, and the language used refers to the carry. ing into execution of the punishment deemed necessary for the American criminal.

The importance of this correspondence is unquestionable. It shows that the actual practice in the earlier years of treaty relations between the United States and Turkey exactly corresponded with what the American government, after reexamination of the text of the treaty and patient investigation regarding the usages in extraterritorial jurisdiction in Turkey, declared that it was willing to accept. This final position of the United States was declared in the instructions given by Secretary of State Blaine, December 22, 1890, in the case of Gurdjian, charged with a political offense against Turkey. These instructions have since been included in the general instructions to American representatives in Turkey. ${ }^{1}$ The United States was willing to yield on the question of trial and to permit the rest of the article to stand without interpretation until occasion should arise. When Turkey declined, the long controversy ended.

The later American treaties with Turkey do not enlarge the scope of consular jurisdiction beyond that contemplated by the treaty of 1830 . The commercial treaty of 1862 conLater treatles with Turkey tained a most-favored-nation clause in the ordinary form, and before it became obsolete in $\mathbf{1 8 8 6}$ the Ottoman Porte had admitted that in the future the United States should continue to enjoy, in respect to the matters covered by this treaty, equal treatment with other powers.

1 For. Rel. 1900, p. 915. Correspondence relating to the trial of Vartanian in the summer of 1905 for murder is not published at this writing.

2 President Cleveland's annual message, December 8, 1885, For. Rel. 1885, p. xiv. 
Real estate protocol, 1874

There is a convention between the United States and Turkey of August 11, 18\%4, for the extradition of criminal offenders. ${ }^{1}$

In view of the mutual advantages that would be derived from a convention regarding naturalization it appears strange that the various attempts made in that direction have as yet been unsuccessful.

By the protocol of August 11, 1874, ${ }^{2}$ relating to the right to hold real estate in Turkey, it is provided that in places distant nine hours or more from the residence of a consular officer, the agents of the public force, on request of the local authority and in the presence of three members of the council of elders of the commune, ${ }^{3}$ may enter into the residence of a foreigner without the usual formality of the presence of a consular officer, but only in case of urgency and for the search and proof of certain heinous crimes. The protocol also provides that in similar distant localities in which the law of the judicial organization of the vilayet shall be in force. foreigners shall be tried, without consular assistance, by the council of elders acting as justices of the peace and by the tribunal of the canton, both in actions not exceeding one thousand piastres in value and for offenses entailing a fine of not more than five hundred piastres; and in any locality whatever, foreigners may submit to the jurisdiction of the previously mentioned Turkish courts without consular assistance and after giving consent in writing; yet in all instances where Turkish courts exercise this jurisdiction, a right of appeal to the tribunal of the arrondissement, with the usual assistance of the consul, is reserved.

In the opinion of the ambassador of France at Constantinople, M. Bourée-with whose assistance the real estate protocol submitted to the powers and, it is believed, the real estate law of 1867 as well, were framed by the Ottoman

1 Infra, p. 105.

2 The English version of the protocol appears in 18 Stat. at Large, 850 . The original of the corresponding French protocol of June 9, 1868, is given in De Clercq, Recueil des traités de la France, vol, 10, p. 76.

s As to administration of justice in the vilayets see Aristarchi, Legislation Ottomane, Constantinople, 1873-81, vol. 2, p. 273. 
Porte-although the law and protocol specify "slight derogations to the capitulations, ... the ancient guaranties are therein none the less formally maintained." 1

Although the United States entered into treaty relations with most of the Mohammedan governments at an earlier period than it did with China and Japan, yet the commerce between America and the Far East had long been of far greater value than American commerce in the Levant. The goods sold to the Chinese were, for the most part, skins and furs taken in the South Seas and from the Oregon territory, besides South American and tropical products obtained in exchange for American domestic products in Peru, Chile, East India and the Malay archipelago. ${ }^{2}$

The system of trading at Canton was controlled by The specially authorized mercantile corporations called 'cohongs' or 'hongs,' that is, 'warehouse' or wholesale merchants. These hong merchants provided every facility of trade, including excellent methods of banking, exchange and credit, and it was due to their ability and justice in the administration of affairs that commerce with China prospered so regularly before the treaties were made. The abolition of the hong system of the treaties was due, it is believed, to the desire of foreign merchants to break its monopoly and thus to enjoy the advantages of a more general competition among the Chinese merchants. ${ }^{3}$

The British treaty of Angust 29, 1842, though it imposed upon China a traffic in opium which China had opBritish treaties, posed in a most bitterly fought and expensive war, benefitted the world by the opening of the historic 'five ports' to the residence and trade of foreigners from the West. This treaty and a supplementary one of 1843 embraced general regulations providing for extraterritorial jurisdiction

\footnotetext{
${ }^{1}$ Archives diplomatiques, 1868, pt. 4, p. 1704. A translation of M. Bourée's letter is given and commented upon in Van Dyck, Capitulations of the Ottoman Empire since 1150, Sen. Ex. Doc. 3, p. 80, Spec. Sess. of 1881.
}

${ }^{2}$ Ho. Ex. Doc. 248 (vol. 7), 26th Cong., 1st Sess.

${ }^{3}$ Ho. Ex. Doc. 119 (vol. 3), 26th Cong., 1st Sess.

Treatles with China of 1844 and later hong system 
and were the first concessions of this kind made by China in the modern series of treaties. ${ }^{1}$

Destre or The treaty with China next in order of time to the can mer- British was the American. For several years before the chants outbreak of the Opium War American merchants had been treaty petitioning their government to negotiate with China. The disorder and violence caused by the opium traffic, a traffic with which Americans had nothing to do, prompted a number of commercial houses in Canton to send a memorial to Congress praying for the immediate negotiation of a treaty. One of the desired stipulations was: "That until the Chinese laws are distinctly made known and recognized, the punishment for wrongs committed by foreigners upon Chinese, or others, shall not be greater than is applicable to the like offence by the laws of the United States or England; nor shall any punishment be inflicted by the Chinese authorities upon any foreigner until the guilt of the party shall have been fairly and clearly proved."2 In 1843 Congress appropriated $\$ 40,000$ to enable the President to send a commissioner to negotiate with the governments of China and the Sandwich Islands. Caleb Cushing, of Massachusetts, was appointed to this office. Upon reaching Macao Mr. Cushing communicated with the imperial government through its provincial representative, announcing his intention to go to Peking by way of the Peiho River and Tientsin. But the Emperor sent his commissioner, Prince Tsi-Yeng, to Macao instead, and the treaty was negotiated there without incident, in the brief period of fifteen days, and was signed at the village of Wang-Hiya, July 3, 1844.

Mr.

Cush-

ing's

negotiations

The dispatches sent by Mr. Cushing to his government review at some length the history and principles of consular jurisdiction in the Orient. ${ }^{3}$ They state that China had always assumed jurisdiction of crimes committed within

1 Brit. and For. State Papers, vol. 30, p. 389, 401; vol. 31, p. $132,155$.

Ho. Ex. Doc. 40 (vol. 2), 26 th Cong., 1st Sess. A similar memorial was sent by merchants of Salem, Mass.; Ho. Ex. Doc. 170 (vol. 4), 26th Cong., 1st Sess.

- Sen. Ex. Doc. 58 and 67 (vol. 2), 28 th Cong., 2d Sess. 
its dominions by all foreigners excepting the Portuguese, who had special privileges at Macao. ${ }^{1}$ But, in fact, for a long period after they were granted the privileges, the Portuguese did not enjoy exemption from Chinese jurisdiction. On the other hand, by the treaties of $1689^{2}$ and $1727,{ }^{3}$ between China and Russia, the leading men of the two Russian caravans permitted to come annually to Peking were to have full jurisdiction over their respective caravans, and criminal offenders, taken in one country or the other, were to be conducted to the frontier for trial and punishment under the jurisdiction of their own gorernment. In the south of China the native anthorities very strictly enforced the rule of territorial jurisdiction, and rather than have all trade stopped, as the authorities threatened to do if offenders were not given up, the captains of merchant ships were accustomed to hand over seamen offenders to Chinese jurisdiction.* The single instance of surrender of an American protected person, so far as $\mathrm{Mr}$. Cushing knew, was that of a seaman, named Terranuova, in 1821. His surrender had been regarded by other Americans in China as a recognition of Chinese territorial jurisdiction.

Two eases of violence implicating Americans had occurred while Mr. Cushing remained at Macao. The first was the shooting and killing of a Chinaman by an American in selfEarly difficulties known to Mr. Cushdefense during the attack of a Chinese mob upon American merchants in Canton; the Chinese demanded his surrender, but it was not granted. The second was the killing of an American by Chinese soldiers. There was considerable correspondence over this case; the offenders were tried in a Chinese court. These circumstances may explain what caused Mr. Cushing to discuss extraterritoriality at such length and with such detail, both in his dispatches as commissioner to China and subsequently in his opinions as attorney-general.

${ }^{1}$ Infra, p. 164.

2 Archives diplomatiques, 1861, pt. 1, p. 271.

s Ibid., p. 276.

- Sen. Ex. Doc. 58 and 67 (vol. 2), 28 th Cong., 2 d Sess. 
It had been stipulated in the American treaty of 1844 , as in the British and French treaties of approximately that date, that at the expiration of twelve years the United States and China, in case of need of modification of parts of the treaty relating to commerce and navigation, would enter into negotiations for this purpose. The end of this period found China not only struggling to overcome the Taiping rebellion but also suffering humiliation in a war in which Great Britain and France were avenging certain acts of violence upon their subjects in the provinces. The United States had been invited to participate in the British and French hostilities upon China, but had declined to do so, declaring the American policy toward China to be simply "to furnish protection to the persons and property of our citizens, and to extend and increase the facilities for commercial operations by arrangements with the government, and by securing their faithful observance, leaving to individual enterprise to make the most of the advantages thus gained." 1 Before the war had really ended Great Britain and France had undertaken negotiations for new commercial treaties. To negotiate a new American treaty President Buchanan sent William B. Reed to China with instructions that while he was to communicate with the plenipotentiaries of Great Britain, France and Russia on subjects of mutual concern, he was constantly to bear in mind the pacific and friendly attitude of the United States toward China. The instructions made special mention of the probable advantage of coöperating with the Russian plenipotentiary because of the peaceable relations which then existed between Russia and China. ${ }^{2}$

The Chinese were very reluctant to make a new treaty and even claimed that the first treaties had been intended

1 Sen. Ex. Doc. 47, p. 7 (vol. 12), 35th Cong., 1st Sess.; see also Sen. Ex. Doc. 22 (vols. 8 and 9), 35th Cong., 2d Sess.; and Sen. Ex. Doc. 30, p. 351, 382, 429 (vol. 10), 36th Cong., 1st Sess. At p. 361 of Doc. 30, supra, Mr. Reed said that without the missionaries as interpreters, referring especially to Dr. W. A. P. Martin, the public business could not have been transacted.

2 Sen. Ex. Doc. 47, p. 2 (vol, 12), 35th Cong., 1st Sess. 
to be permanent. The Russian treaty was the first to be signed and the American next. The principal privileges newly secured were that the foreign ministers were to have the right of residence at Peking, that the number of open ports was increased to eleven and that there was to be a commutation of internal transit taxes by the payment of a single tax at the port of entry or, if the goods were to be exported, at the first tax barrier. It was also stipulated that a system of passports for travel in the interior should be inaugurated. The acquisition of land at or near the ports was to be facilitated; the Chinese government was committed to a tolerant policy toward Christianity and toward native converts and, lastly, the stipulations concerning extraterritorial jurisdiction were stated more clearly and fully. ${ }^{1}$

The American treaty of November 1\%, 1880, also bears directly upon consular jurisdiction in China by giving its Treaty of 1880 sanction to a usage that had been developing since 1858, that is, the attendance and participation of an official of the plaintiff's nationality at the trial of mixed cases before a judge of the defendant's nationality. ${ }^{2}$

The treaty of October 8, 1903, contains no provision relating to extraterritorial jurisdiction, but it makes much Treaty of 1903 fuller stipulations regarding certain commercial privileges and grants additional privileges. ${ }^{3}$

The first acquaintance of American navigators with the coasts of Japan came about during their extensive whaling cruises in the North Pacific Ocean. The masters of whaling Treatles with Japan of 1854 and ships desired to refit and supply them in Japanese harbors. In 1831 a Japanese junk was blown out to sea and, crossing the ocean, found refuge on the shores of the Oregon territory near the mouth of the Columbia River. An American ship when taking the survivors back to Japan and entering

${ }^{1}$ Mr. Reed's dispatches spoke most earnestly of the need of improving American consular jurisdiction in China and showed how, for the lack of proper prisons, criminals were often discharged without suffering their penalties; Sen. Ex. Doc. 30 (vol. 10), 36th Cong., 1st Sess., p. 355.

- For. Rel., 1881, p. 199.

Infra. p. 119, 127, 139, 140, 192. 
the bay of Yedo was fired upon from the land batteries and not permitted to put the castaway seamen ashore. Two American ships were wrecked on the coasts of Japan in 1846, and their crews would not have been permitted to leave the islands but for the friendly entreaties of the Dutch superintendent of trade at Nagasaki. In fact such was the extreme rigor of the Japanese at that time in enforcing the governmental policy of absolute exclusion which had been occasioned by the abuse of privileges accorded to foreigners at an earlier period, that Japanese who had been abroad and were found to have returned to Japan were punished with death. For the crew of an American whaling ship stranded on the shores of Japan there was little or no possibility of getting friendly assistance. Not long before the negotiation of the treaty with the United States, the Japanese had gratified their curiosity respecting foreigners by carrying about shipwrecked American seamen for exhibition in wooden cages!

Another circumstance that made a treaty with Japan desirable was that upon the acquisition of California by the United States a new interest in the commerce of the Far East arose, and it was hoped that the Japanese would consent to supply trans-Pacific steamships with coal, for without this coöperation steam navigation across the Pacific was thought to be impracticable.

Commodore Pertiations, 1854

These details not only explain the occasion for the treaty concluded by Commodore Perry on May 31, 1854, but also indicate its real objects. Its first importance was, of course, that it brought Japan into treaty relations with a friendly western power, whereas Japan had, up to that time, made no treaty with any western state. It granted the United States the right to appoint consuls or agents to reside in the city of Simoda. Simoda and Hakodade were to be open for a limited trade and for the refitting and supplying of ships. Within seven and five Japanese miles of these ports respectively Americans were to be free to travel at their pleasure; and this was a notable concession, for the Chinese and Dutch traders at Nagasaki had been actually secluded 
within stockades. But it is chiefly worthy of note that the Perry treaty of 1854 contained no provision whatever as to extraterritorial privileges or consular jurisdiction. There was, however, a provision among the twelve regulations made in amplification of the treaty that Americans who were found "transgressing Japanese laws" might be apprehended "by the police and taken on board their ships." 1 The suggestion of including this regulation appears to have arisen from the commission of a crime by an American seaman at the Lew Chew Islands, then assumed not to be under Japanese sovereignty, while Commodore Perry's squadron was stationed near those islands during an interval in the negotiations with Japan. A separate treaty, including a provision that American offenders should be reported to the captain of the ship to which they belonged, was concluded by Commodore Perry with the government of Lew Chew, July 11, 1854.2

The first American representative in Japan was Townsend Harris, a merchant of New York City, who had been making extensive trading voyages in the Far East for several years previous to his appointment in 1855. Mr. Harris was first end Harappointed as consul-general in Japan with commissions to negotiate new treaties with both Japan and Siam. He was eminently successful in both negotiations. His career in Japan was distinguished for ability, justice and honor. In negotiating the Japanese treaties of June 1\%, 185\%, and July $29,1858,{ }^{3}$ Mr. Harris, truly representing the disposition of his government toward Japan, displayed so fair and generous a spirit, that these treaties, the first of a series of commercial treaties with western powers, were regarded with the

${ }^{1}$ Sen. Ex. Doc. 34, p. 161 (vol. 6), 33 d Cong., $2 \mathrm{~d}$ Sess.

2 The British treaty of October 14, 1854, provided that British subjects in Japan should be subject to the laws of Japan and that British offenders should be punished under British jurisdiction; Brit. and For. State Papers, vol. 44, p. 62 .

$s$ The treaty of 1857 provided for jurisdiction of crimes only, that of 1858 for jurisdiction of both civil and criminal cases. The British treaty of August 26, 1858, was more in detail, and the Austro-Hungarian treaty of October 8,1869 , was the most elaborate of all treaties made with Japan. In his later years Mr. 
greatest satisfaction by the Japanese authorities, and, being models for the European treaties, they actually served to protect Japanese interests to such an extent that Mr. Harris was thought of as a national benefactor of Japan. As the Harris treaties were the first commercial treaties with Japan, they were also the first to introduce extraterritoriality. Neither Mr. Harris nor the Japanese authorities at the time regarded these extraterritorial privileges as a marked disparagement to Japanese sovereignty, although Mr. Harris in his diary expressed surprise that the privileges were so readily granted. ${ }^{1}$ What was the immediate cause for introducing them does not appear. The correspondence relating to the negotiations has not been published. The privilege of having the treaty revived in $18 \% 2$ or later was reserved, but, notwithstanding the desire of Japan, this treaty and the treaties with other powers of approximately the same date remained in force as to their extraterritorial provisions until July 16, 1899.

Siam,

1833, 1856

Mr. Harris's negotiations with the Siamese government while he was en route to Japan resulted in the treaty of May, 29,1856 , which amplified and modified to a large degree the privileges secured by the treaty negotiated by Captain Roberts in 1833 . The treaty of 1833 had not made a direct grant of extraterritoriality; the treaty of 1856 made a grant of it in its fullest form, and this treaty of 1856 is the basis of American foreign jurisdiction in Siam to-day.

Madagascar,

The native government of Madagascar entered into a treaty with the United States on February 14, 186\%, and made a new treaty on May 13, 1881, which defined consular judicial prerogatives with extraordinary detail. Since 1896 Madagascar has been a colony of France. ${ }^{2}$

Korea, 1882

After several attempts to enter into treaty relations with Korea the treaty of May 22, 1882, was negotiated. The special envoy of the United States was Commodore Shufeldt,

Harris said that the extraterritoriality of Americans in Japan was against his conscience; Griffis, Townsend Harris, Boston, 1896, p. 332.

1 Griffis, Townsend Harris, p. 124.

Infra, p. 179. 
and the negotiations were facilitated by the support and influence of Li Hung Chang. This was the first treaty between Korea and a western power, the British and German treaties being of a date eighteen months later. The fourth article of the American treaty contains a provision which is thought not to have been inserted in any earlier treaty with any oriental state, namely, that extraterritoriality shall be relinquished when, in the judgment of the United States, the reform of the laws and of the administration of justice in Korea justify relinquishment; a similar provision is made in the protocols appended to the British and French treaties.

A treaty was made with the Sultan of Borneo, June 23, 1850 , and it is still in force, although the island is now entirely included within British and Dutch protectorates. The Borneo treaty is peculiar in that it gives the American consul jurisdiction over disputes arising between American citizens and subjects of the Sultan irrespective of the nationality of the defendant and absolutely prohibits interference in any litigation before the consul whatever the nature of the case.

On Jamnary 17, 1878, a treaty was made with Samoa. This treaty was negotiated at Washington and signed by the Secretary of State himself. The Samoan Islands, were divided, however, by a treaty hetween the United States, Great Britain and Germany, December 2,1899 , under which the rights and claims of Great Britain were renounced as to the entire group of islands and the rights and claims of the United States and Germany restricted to separate groups of the islands.

On October 2, 1886, a treaty with the Tonga Islands was concluded. These islands became a protectorate of Great Samoa, 1878 Britain in 1899, and in 1904 the native authorities transferred the legal and financial administration to the British government.

None of the treaties between the United States and the Hawaiian Islands contained provisions for extraterritorial jurisdiction. In the treaty of October 21, 1862, with Liberia the United States engages, if desired, to give assistance with 
a military force in bringing aboriginal inhabitants, aggressors upon the peace of Liberia, to justice. The exercise of jurisdiction in the Congo Free State appears not to be well determined; it was much discussed in 1896 in the trial of Major Lothaire. ${ }^{1}$ The rapid partition of Africa and the groups of islands of the South Pacific Ocean among European powers has narrowed the application of the provision of the Revised Statutes that jurisdiction may be exercised in barbarous or uninhabited countries not governed by any recognized authority.

Enumeration of the treaties in force
The many changes in the international relations of the oriental states with which the United States has, during the course of the past century, negotiated treaties of extraterritoriality, have greatly reduced the number of those treaties and caused some of them, though remaining in force, to be modified in operation. The extrateritorial jurisdiction has been formally relinquished in Algiers and Tunis, Servia, Madagascar and Japan and a portion of Samoa, and impliedly relinquished in Roumania; it is suspended as to certain civil cases in Egypt, and fully suspended within the areas of North China leased to European powers; it is subject in greater or less degree to modification or suspension in the protectorates of Zanzibar, ${ }^{2}$ Borneo and Tonga, and in the special spheres of influence of France and Italy extending over Morocco and Tripoli; it is still exercised in Persia, Maskat, Siam, Korea, China and Turkey; and in Turkey and China it is frequently exercised and of great importance.

1 Archives diplomatiques, 1896, pt. 3, p. 166.

supra, p. 20, and infra, p. 181. 


\section{ACTS OF CONGRESS \\ ESTABLISHING THE SYSTEM OF CONSULAR COURTS}

The earliest Act of Congress relating to consular juris- Act of diction in the Orient was that of August 11, 1848. ${ }^{1}$ In reporting the bill the Senate Judiciary Committee stated that the measure was considered necessary to the execution of the treaty with China of 1844 and that the course of action in the British Parliament had been examined.'

The next legislation was that of June 22, $1860 .^{3}$ It was occasioned by the newly made treaties with China, Japan and Siam. Like its predecessor it was enacted without debate. It extensively amplified and improved the earlier legislation, and, together with the Act of July 1, 18\%0, ${ }^{4}$ relating to appeals in certain cases, formed the basis of the law as embodied in the Revised Statutes, Sections 4083-4130.5

These statutes have been importantly modified by the Act of June 30, 1906, creating a United States court for China. ${ }^{6}$

It is repeatedly declared in these statutes that they are intended to carry into effect the treaties which have granted extraterritorial jurisdiction. ${ }^{7}$ The jurisdiction as

19 Stat. at Large, 276.

Congressional Globe, 30th Cong., 1st Sess., p. 648-9, 665, 822, 1008.

12 Stat. at Large, 72. The bill that became the Act of 1860 was prepared in the Department of State; for the action of Congress upon it, see Congressional Record, 36th Cong., 1st Sess., p. 2167, 3218. A general reorganization of the consular system had taken place under the Act of August 18, 1856; 11 Stat. at Large, 52.

- 16 stat. at Large, 183.

- Rev. Stat. Sec. $40 \$ 3-4130$ are printed Infra, Appendix II. The Act of April 5, 1906, reorganizing the consular system, will, in connection with the Act of June 30, 1906, and the Executive Order of June 27, 1906, effect much improvement of the exercise of judicial functions by consuls in the Orient; the Act is printed infra, Appendix III-1.

B The Act is printed infra, Appendix III-2.

' Sec. 4083, 4085, 4086, 4100, 4108, 4117, 4125, 4127, 4129. 
Relation of the statutes to the treaties

provided for in China, Japan, Siam, Egypt and Madagascar is described with some fullness, and the differences in jurisdiction in other countries are described separately. ${ }^{1}$ The provisions of the Act extend to Turkey, under the treaty of 1830 , so far as they relate to the punishment of crimes, and also in relation to civil controversies wherein civil jurisdiction is permitted under usages existing in Turkey or under the laws of Turkey. ${ }^{2}$ The provisions extend to Persia in respect to all suits and disputes between American citizens in Persia; but mixed cases involving Persians as plaintiffs or defendants in civil or criminal actions are to be tried in Persian tribunals, the consular officer being obliged to attend in person for the purpose of seeing that justice is administered; and mixed cases involving citizens of the United States and subjects of other foreign powers are to be tried under regulations mutually agreed upon between the ministers of the United States and other powers in Persia, respectively, which regulations shall be submitted to the Secretary of State. ${ }^{3}$ Again, the provisions of the statutes extend to Tripoli, Tunis, Morocco, Maskat and the Samoan Islands so far as they conform to existing treaties and to the established nsages in those countries in respect to intercourse with foreigners; and whenever the United States shall negotiate a treaty of extraterritoriality with any foreign government the provisions of the statutes, so far as applicable, shall extend to that country. ${ }^{4}$ The consuls and commercial agents of the United States at islands or in countries not inhabited by any civilized people or recognized by any treaty with the United States are also authorized to exercise extraterritorial jurisdiction in criminal cases and in civil cases, except where the debt or damages exceed $\$ 1,000 .^{\circ}$

${ }^{1}$ Sec. 4083-7, 4125-7.

${ }^{2}$ Sec. 4125. It was necessary to state the law in this way, because the treaty with Turkey had made no specific grant of jurisdiction in civil cases.

${ }^{3}$ Sec. 4126 . It is in respect only to Turkey and to Persia that the language of the statutes suggests the language of the treaties.

+ Sec. 4127.

- Sec. 4083. The grade of commercial agent is abolished; Act of April 5, 1906, Sec. 3; infra, Appendix III-1. 
The second leading feature of these statutes is that they set forth what law is to be applied in consular courts. ${ }^{1}$ The law enjurisdiction in both criminal and civil matters is to be exercised and enforced in conformity with the laws of the United States, which are, by these statutes, and so far as necessary and suitable under the treaties, extended over all citizens of the United States in those countries and over all others who may have the right of American protection. ${ }^{2}$ If the laws of the United States, the statutes continue, are not adapted to the object of the treaties, or are deficient in the provisions necessary to furnish suitable remedies, the common law ${ }^{3}$ and the law of equity and admiralty shall extend in like manner over citizens and other protected persons in those countries; and if neither the common law, nor the law of equity or admiralty, nor the statutes of the United States furnish appropriate and sufficient remedies, the American ministers in those countries, respectively, shall issue regulations which shall supply such defects and deficiencies and shall have the force of law.

The Act of June 30, 1906, in prescribing the jurisdiction of the United States court for China, impliedly removes all jurisdiction and the power of making regulations from the minister to China; it confers this jurisdiction and power upon the judge of the United States court for China. ${ }^{4}$

With some detail the statutes specify that certain matters of procedure, ${ }^{5}$ which, in the United States, are provided for in the law of the several commonwealths, are to be prescribed in the regulations issued by the ministers; and further regulations are to be made from time to time, under Nature of the regulations to be pubilished by the ministers the provisions of the statutes, as the exigency may demand. ${ }^{\circ}$

1 Sec. 4086, 4117-20, 4126.

2 This provision shows that the systems of civil and criminal law which operate in the several states of the American federal union, have no operation whatever under the extraterritorial jurisdiction except so far as is permitted by the federal statutes.

${ }^{3}$ When the bill that became the Act of 1845 was before the Senate, the question was asked: How could the United states be said to have a 'common law'? infra, p. 50-2.

Sec. 1, 2, 3, 4, 5; see Appendix III-2.

- Sec. 4117; see also 4084, 4087, 4059.

- Sec. 4117 . 
In making the regulations the ministers are to request and consider the opinions of the consuls or of so many of them as can be conveniently assembled or can be consulted without prejudicial delay or inconvenience; and the assent or dissent of the consul shall be signified in writing. After thus advising with the consuls the minister may publish the regulation with his signature thereto and the opinions of his advisers inscribed thereon, and such publication shall make the regulation binding and obligatory from the date of its publication or from any subsequent date named in it, and thus it shall have the force of law until annulled or modified by Congress. ${ }^{1}$ Every such regulation, as speedily as may be after its publication, is to be transmitted by the minister

The regulations submitted with the opinions of his advisers, as drawn by him, to the Secretary of State to be laid before Congress for revision. ${ }^{2}$ The minister may issue all manner of writs to prevent citizens of the United States from enlisting in the military or naval service of the country to make war upon any foreign power with whom the United States are at peace, or in the service of one portion of the people against any other portion of the same people; and he may carry out this power by a resort to such force belonging to the United States as may at the time be within his reach. ${ }^{3}$ The minister shall prepare a form of submission for civil cases, which, by mutual agree-

\footnotetext{
${ }^{1}$ Sec. 4117 , 4118. The principal regulations for Turkey and China were drawn up by the consuls-general in Constantinople and Shanghal. The public documents show that the earlier regulations for China were made with the formality prescribed by law respecting the expression of assent thereto or dissent therefrom on the part of the consuls. No regulations, it is belleved, have been annulled or modified by Congress, not even certain regulations for Japan, which the Secretary of State disapproved; infra, p. 54. Similarly Congress did not annul or modify the regulations of March 8, 1856, for China, relating to the exercise of judical functions by vlceconsuls; they had, however, been disapproved by Attorney-General Cushing. In 1858 a resolution was adopted in the Senate to confirm the regulations for China of March 4, 1857; Congressional Globe, 35 th Cong., 1st Sess., pt. 2, p. 1203, 1555. In all other instances the action of Congress has been confined to reference to a committee and order to be printed.

A table of the regulations is printed infra, Appendix XI-1.

2 Sec. 4119.

Sec. 4090.
} 
ment of the parties to the controversy, are to be settled by decision of referees. ${ }^{1}$ He shall also establish a tariff of fees for judicial services and shall direct by whom and to whom they shall be paid, and the proceeds of these shall, as far as is necessary, be applied to defray the expenses incurred under these statutes, and regular accounts shall be transmitted annually to the Secretary of State. ${ }^{2}$ The minister to Persia is specifically empowered to agree upon regulations with ministers of other powers to Persia for the adjudication of mixed cases arising between foreigners of different nationalities in that country. ${ }^{3}$

The third essential feature of the statutes is that they invest with certain judicial authority ${ }^{4}$ the ministers and consuls duly appointed to reside in the countries where extraterritoriality exists. ${ }^{5}$ If there is no minister so appointed to reside in a particular country, his judicial authority and the obligation to discharge the duties connected with it, devolve

Conferring of judicial authority upon Incumbents of certain offices upon the Secretary of State. ${ }^{6}$ The word 'minister' here used is declared to mean the person invested with and exercising the principal diplomatic functions; and the word 'consul,' any person invested by the United States with, and exercising, the functions of consul-general, vice consulgeneral, consul or vice-consul. ${ }^{7}$ These officers are declared to be responsible to the United States and to the laws thereof in the performance of their judicial duties. ${ }^{8}$ The ministers have authority to exercise jurisdiction wherever they may be in the countries in which they are appointed to reside. ${ }^{9}$ The consuls have such authority at the ports where

${ }^{1}$ Sec. 4098.

'Sec. 4120.

${ }^{3}$ Sec. 4126.

'The title of the Act of 1860 read 'giving certain judicial powers.'

'Sec. 4083, 4084, 4085. See list of legations, court, and consulates, Appendix XI-3.

S Sec. 4128.

'Sec. 4130 ; see also Sec. 1674. By Sec. 4088 commercial agents resident in clvilized countries are also included among officers having judicial authority.

${ }^{8}$ Sec. 4110.

- Sec. 4108. 
their consulates are situated. ${ }^{1}$ The jurisdiction of the ministers is appellate only, except that in capital cases for murder or insurrection against the government of the country, in case of offenses amounting to felony under the laws of the United States, and in cases where a consular officer is interested, either as party or witness, the minister is to have original jurisdiction. ${ }^{2}$

Settlement of certain cases without resort to

IItI-

gation
Jurisdiction of a consul acting alone
In the fourth place the statutes declare it to be the duty of ministers and consuls to encourage the settlement of controversies of a civil character by mutual agreement or by submitting them to the decision of referees agreed upon by the parties; the manner in which referees shall hear and decide such cases and consuls shall signify their acceptance of the decisions and cause them to be executed, is specified in detail; but at any time before the award of the referees is returned to the consul, it is permitted the parties to settle the difficulty themselves. ${ }^{3}$ In criminal cases which are not of a heinous character, it is lawful for the parties aggrieved or concerned therein, with the assent of the minister or consul, to adjust and settle the same among themselves upon pecuniary or other consideration. ${ }^{4}$

Fifthly, it is provided that the consul sitting alone as judge for the trial of offenses or misdemeanors shall decide finally all cases where the fine imposed does not exceed $\$ 100$ or the term of imprisonment sixty days, ${ }^{5}$ and it is lawful for him sitting alone to decide all cases in which the fine imposed does not exceed $\$ 500$ or the term of imprisonment ninety days; but if the fine exceed $\$ 100$ or the term of imprisonment sixty days, the case may be taken by appeal before the minister, if allowed jurisdiction. ${ }^{\circ}$ All civil cases

${ }^{1}$ Sec. 4085, 4087; under the Act of June 30, 1906, the judicial powers of the minister in China are transferred to the judge of the United States court for China, and certain powers of the consuls are likewise transferred to this court.

2 Sec. 4109.

Sec. 4098.

Sec. 4099.

Sec. 4105.

Sec. 4089. 
wherein the damages do not exceed $\$ 500$ may be decided by the consul without aid and finally. ${ }^{1}$

The United States court for China has exclusive jurisdiction in all cases except that consuls continue to have jurisdiction as formerly in civil cases of not more than $\$ 500$ value and in criminal cases punishable by $\$ 100$ fine or sixty days' improsinment or both; and consuls have power to arrest, examine, and discharge accused persons or commit them to the said court. From all final judgments of the consular court either party may appeal to the Uniter States court for China.

Sixthly, the statutes provide that the consul may be assisted upon the trial, either civil or criminal, by citizens of the United States who shall be of good repute and competent for the duty and who shall be chosen by lot from a list previously approved by the minister, with the additional His jurisdiction when asgisted oy citizen asso-
clates on the trial requirement in civil cases that these citizens be resident at the port. The number of associates in criminal cases is to be one or more, in capital cases not less than four, and in civil cases not less than two nor more than three. The consul is to summon associates to sit with him on the trial whenever, by reason of legal questions involved in the case, he is of opinion that assistance will be useful, or whenever, in criminal cases, certain severe punishments will be required or whenever in civil cases the damages demanded exceed $\$ 500$. The associates are to enter upon' the record their several opinions and their assent to or dissent from the judgment, but the consul alone is to give judgment in the case. If the consul and his associates concur in the opinion, the decision in all civil and criminal cases, except in cases of Associates asdissent from the capital offenses, shall be final. If, in a criminal case, any of the associates differ in opinion from the consul, the case, without further proceedings and together with the evidence and opinions, shall be referred to the minister for his adjudication, and he may either enter up judgment therein or remit the case to the consul with instructions how to proceed therewith. If, in a civil case, any of the associates differ in

\footnotetext{
1 Sec. 4107.
} 
Jurise diction of the minister

Capital offenses and jurIsdiction of them

opinion from the consul, either party to the case may appeal to the minister; but if no appeal is lawfully claimed under the regulations for appeal, the decision of the consul shall be final. ${ }^{1}$

These provisions allowing consuls to summon associates have no application to the United States court for China. ${ }^{2}$

Seventhly, the statutes empower the minister to decide finally any case brought before him by appeal, either upon the evidence which comes up with it or upon hearing the parties further, if he thinks justice will be promoted thereby; and he may also prescribe the rules upon which new trials may be granted either by the consuls or by himself if asked for upon sufficient grounds. ${ }^{3}$

The Act of June 30,1906, impliedly transfers the judicial authority of the minister to China to the judge of the United State court for China, and gives the judge of this court power to modify and supplement the rules of procedure prevailing in the consular courts of China under the statutes. ${ }^{4}$

Eighthly, it is provided that the trial for insurrection or rebellion against the government of the country, with intent to subvert the same, and the trial for murder may be originally held either in the court of the minister or in the court of a consul sitting with associates; no person may be convicted of either of those crimes unless the consul and his associates concur in opinion and the minister also approves the conviction; and it is lawful, if one is put upon trial for either of these crimes, to convict him of a less offense of similar character. ${ }^{5}$ Whenerer any persons is convicted of either of the crimes punishable with death, it becomes the duty of the minister to issue his warrant for the execution of the convict, appointing the time, place and manner; but if the minister is satisfied that the ends of public justice demand it, he may from time to time postpone such execution; and if he finds mitigating circumstances which

1 Sec. 4106, 4107.

${ }^{2}$ Sec. 5 .

Sec. 4091.

- Sec. 1, 2, 5.

s Sec. 4102. 
authorize it, he may submit the case to the President for pardon. ${ }^{1}$ 'The punishment of all other crimes is by fine or imprisonment. ${ }^{2}$

Ninthly, the statutes made provision (no longer in force) that on any final judgment in a consular court of China where the matter in dispute exceeded $\$ 500$, and did not exceed $\$ 2,500$, exclusive of costs, appeal shonld be allowed to the minister ${ }^{3}$ and where the matter in dispute, exclusive of

Former appellate jurisdiction of the clrcuit court in Cali-

fornia costs, exceeded $\$ 2,500$, an appeal from a final judgment either in a consular court or in the court of a minister, in China, if he gave judgment in the exercise of original jurisdiction, should be allowed to the circuit court for the district of California. Upon such appeal a transcript of all the proceedings in the cause was to be transmitted to the circuit court, and no new evidence was to be recerved on the hearing of the appeal; the appeal should be subject to the rules, regulations and restrictions prescribed in law for writs of error from district courts to circuit courts. ${ }^{4}$ When any final judgment of the minister to China was given in the exercise of original or of appellate criminal jurisdiction, the person charged with the crime or offense, if he considered the judgment erroneous in point of law, might appeal therefrom to the circuit court for the district of California; but such appeal was not to operate to stay proceedings unless the minister certified that there was probable cause to grant the same, when the stay was to be such as the interests of justice might require. ${ }^{5}$ Power to exercise this appellate jurisdiction was conferred upon the circuit court in California and its decisions in the exercise thereof were declared to be final. ${ }^{6}$

\footnotetext{
${ }^{1}$ Sec. 4103. This is the only reference in Statutes $4083-4130$ to the subject of pardoning criminal offenses committed under the extraterritorial jurisdiction. Authority to pardon is therefore conferred solely upon the President and restricted to capital offenses.

2 Sec. 4101.

${ }^{3}$ Sec. 4092.

4 Sec. 4093, 4094. The statutes include Japan, but their operation with respect to Japan ceased on July 17,1899 , by virtue of treaty; infra,p. 188.

s Sec. 4005.

6 Sec. 4096. By Act of March 3, 1891 (26 Stat. at L. 826, Sec. 4), creating the "circuit courts of appeal," appellate jurisdiction was taken from "circuit courts" and no new provision was made for appeals from consular courts in China; Michigan Law Review, March, 1900, p. 345;
} 
AuthorIty to execute and manner of executing Judgments

Effect of Internatlonal law

From all final judgments of consular courts in China and Korea either party has the right of appeal to the United States court for China; and from all final judgments or decrees of this court appeals lie to the United States circuit court of appeals of the ninth judicial circuit and thence to the Supreme Court of the United States. ${ }^{1}$

Tenthly, the ministers and consuls are authorized to issue all processes suitable and necessary to carry their judicial powers into execution, ${ }^{2}$ and for executing such processes marshals are appointed under authority conferred by these statutes upon the President, and the duties of these marshals and their liability for the performance of their duties are prescribed. ${ }^{3}$ The President is authorized to allow, in the adjustment of the accounts of certain consuls, the actual expenses of renting prisons for American convicts, and the wages of prison keepers and constables. ${ }^{4}$ The ministers and consuls are fully authorized to call upon the local government to sustain and support them in the execution of the powers confided to them by treaty, and on their part to do and perform whatever is necessary to carry the provisions of the treaties into effect, so far as they are to be executed in these countries respectively. ${ }^{5}$

The office of marshal in China existing under Section 4111 of the Revised Statutes is abolished. The Act of June 30, 1906, creates the office of marshal of the United States court for China. ${ }^{6}$

The language of the statutes, 'to carry into full effect the provisions of the treaties,' is a recognition of the fact that the specification of certain powers and duties of ministers and consuls is not intended to exclude them from the enjoyment of other powers and the performance of other duties

Nee Chang Mow $*$. George, Shanghai, 1903, cited infra, p. 62; report of the Third Assistant Secretary of State, Mr. H. H. D. Peirce, October 29,1904, p. 9 ; supra, p. 63 and note 2 . The question has not been before a court in the United States and it appears not to have been considered in any official opinion of a law-officer of the government.

${ }^{1}$ Sec. 2, 3. 2 Sec. 4084, 4091. ${ }^{3}$ Sec. 4111-6. 4Sec. 4121-4.

${ }^{5}$ Sec. $4100 . \quad$ 'Sec. 6, 8. 
which belong to them under particular treaties ${ }^{1}$ or by virtue of their offices as defined under international law. ${ }^{2}$ It is also a well-known principle that treaties which are complete in themselves need no supplemental legislation. It was so held by the Supreme Court in Daniese $v$. Hale in 1875 , a case in which the exercise of judicial functions in civil cases in Egypt was sustained. ${ }^{3}$ And in the Ross case in 1890 the same court held that although consular courts are courts of limited jurisdiction, the treaties and statutes pertaining to their jurisdiction are not, by construing their meaning too narrowly, to be so restricted as to defeat their purpose. ${ }^{4}$

'The question of what law is applicable in such and such cases in American consular courts becomes at times very difficult on account of the insufficiency of the provisions of the present statutes. It is one of the objects of these statutes to extend over citizens in certain oriental countries a system of law as nearly as possible like the system to which they are accustomed in their own country. But in this country the ordinary affairs and relations of life are subject to the law of the commonwealth or state in which a citizen resides, and it would be impossible for consular courts to administer justice according to the diverse systems of law in force in the various states. To obviate this difficulty the statutes provide definitely upon certain points, but, upon the great body of legal rights, they provide only that the common law and the law of equity and admiralty shall be in force.

What does the term common law used in this relation signify? The supreme court of California in Forbes $v$. Scannel ${ }^{5}$ held that it had the same significance in respect to

${ }^{1}$ See also Rev. Stat., Sec. 1714, 1752. This is supported by the opinion of Mr. Justice Story in regard to the authority of consuls in nonjudicial matters in construing the Act of April 14, 1792 (1 Stat. at Large, 254) in Potter v. Insurance Co., 3 Summer 44.

"Upon international law as part of United States law, see the opinion of Mr. Justice Gray, in the case of the Paquete Habana, $17 \overline{5}$ U. S. 677,700 .

${ }^{3} 91$ U. S. $13,16.4140$ U. S. $453,480$.

$\checkmark 13$ California 242. The question under discussion was what law governed a certain assignment made at Canton, China, in 1856. 
AttorneyGeneral Cushing's opinion

the jurisdiction of consular courts that it had been held by Chief Justice Marshall in the trial of Aaron Burr to have in respect to the jurisdiction of federal courts, that is, it referred to "those general principles and those general usages which are to be found, not in the legislative acts of any particular state, but in that generally recognized and long established law, which forms the substratum of the laws of every state"; ${ }^{1}$ and the California court further cited an opinion of Attorney-General Cushing in which he discussed the provisions of the Act of August 11, 1848, and said of the term common law that in using it "the statute furnishes a code of laws for the great mass of civil or municipal duties, rights, and relations of men, such as, within the United States, are of the resort of the courts of the several states." But Mr. Cushing admitted that the statement just quoted did not specifically explain the term, for he went on to say "it was not enongh to enact that the common law should intervene to supply, in China, deficiencies in the law of the United States. For the question would be sure to arise: What common law? The common law of England at the time when the British colonies were transmuted into independent republican States? Or the common law of Massachusetts? or that of New York, or Pennsylvania, or Virginia? For all these are distinct, and in many important

1 The question before the court was whether bail was demandable from a person actually in custody against whom an indictment for a misdemeanor had been found by a grand jury; and, as conducing directly to a decision on that point, a second question was discussed, whether a summons or a capias would be the proper process to bring the accused in to answer the indictment, if, in point of fact, he was not before the court.

It had been contended that since Section 34 of the Act of September 24,1789 , as to the judiciary, required the adoption by the federal courts of the ruies of decision existing in the laws of the severai states In triais at common law in cases where they apply, the established practice of Virginia, where the court was sitting, should be foilowed and a summons issued in the first instance.

But the court said: "It might certainiy be weil doubted, whether this section, if it should be construed to extend to ail the proceedings In a case where a reference can be made to the state laws for a rule of decision at the trial, can comprehend a case where, at the triai in chief, no such reference can be made. Now in criminai cases the laws of the United States constitute the sole rule of decision, and no man 
respects diverse, 'common law.' To dispose of this difficulty, the statute went one step further, and enacted that . . . 'decrees and regulations' may be made from time to time by the commissioner, which shall have the force of law, and 'Common law' to be supplemented by regulasupply any defects or deficiencies in the common law and the law of the United States. This power of supplementary decree or regulation serves to provide for many cases of criminality, which neither federal statutes nor the common law would cover. . . In certain respects, therefore, the commissioner legislates [italics quoted] for citizens of the United States in China"; it being required that the regulations shall be transmitted "to the President to be laid before Congress for its revision." 1

The Act of June 30, 1906, relating to the United States court for China, declares that when the laws of the United States are deficient in provisions necessary to give jurisdiction or to furnish suitable remedies, the common law

can be condemned or prosecuted in the federal courts on a state law. The laws of the several states, therefore, cannot be regarded as rules of decision in trials for offences against the United States. It would seem to me too, that the technical term 'trials at common law,' used in this section, is not correctly applicable to prosecutions for crimes. I have always conceived them to be, in this section, applied to civil suits as contra-distinguished from criminal prosecutions, as well as to suits at common law as contra-distinguished from those which come before the court sitting as a court of equity or admiralty.

"The provision of this section would seem to be inapplicable to original process for another reason. The case is otherwise provided for by an act of Congress. The 14 th section of the judicial act empowers the courts of the United States, to issue all writs not specially provided for by statute, which may be necessary for the excercise of their respective jurisdictions, and agreeable to the principles and usages of law.'

"This section seems to me to give this court power to devise the process for bringing any person before it, who has committed an offence of which it has cognizance and not to refer it to the state law for that process. The limitation on this power is, that the process shall be agreeable to the principles and usages of law. By which I understand those general principles and those general usages which are to be found, not in legislative acts of any particular state, but in that generally recognized and long established law, which forms the substratum of the laws of every state."

From these premises the court reasoned that the proper form of process to issue would be a capias; Doc. 230 , p. 184, 10th Cong., 1st Sess., which is contained in President Jefferson's message of November 23, 1807, communicating a report of the trial of Aaron Burr.

17 Goln. Atty-Gen. 503. 
Nature of the regulations which ministers have pub-

lished

and the law as established by the decisions of the courts of the United States shall be applied by said court in its decisions, subject to the terms of the treaties between the United States and China. ${ }^{1}$

The regulations published by the ministers are intended to supplement the provisions of the statutes by making certain rules of procedure and by supplying appropriate and sufficient remedies not provided in the statutes or in the common law or the law of equity or admiralty, thus from time to time including such matters, under the statutes, as the exigency may demand. The public documents contain regulations for China, Turkey, Japan and Korea. ${ }^{2}$ The regulations of 1871 for Japan and of 1892 for Korea were modelled upon the codes of California under the direction of the Ministers C. E. De Long and Augustine Heard respectively; ${ }^{3}$ the regulations for Turkey were prepared by ConsulGeneral Goddard and published in 1863; and, together with an amendatory regulation of 1881 for Japan, these are the only regulations for the three countries named. There have been sixteen sets of regulations for China, the main set of which, corresponding to those for Turkey, Japan and Korea, was drafted by Consul-General Seward and published in 1863; there were supplementary regulations in 1882 and 1889 in matters relating to summons of witnesses and judgments by confession. Several of the earlier regulations for China have nothing to do with procedure; one of them relates to the control of seamen on shore-leave, another to neutral conduct during the Taiping rebellion, another gives authority to hold court on board ship at the five ports ${ }^{4}$

\footnotetext{
1 Sec. 4.

2 A table of the regulations for consular courts is printed infra, Appendix XI-1. The regulations for China and Turkey are printed infra, Appendix IV, IX. The regulations for Korea were very carefully drawn. They follow sections (passim) of the clvil and penai codes of California. It is regretted that their comparatively great length forbids reprinting in the Appendix infra.

s In Meiklejohn $v$. Gring, decided at Kanagawa in 1886, it was held that the rules of practice of the U. S. Circuit Court in California were not of force in consular courts in Japan; Scidmore, Ministerial and Consular Courts of the United States in Japan, Toklo, 1887, p. 234.

- For several weeks court was held by Mr. Parker at Macao; his suc-
} 
through the war of 1856-60, and another prohibits the navigation of the Straw-shoe Canal along the Yangtse River.

The procedure of the United States court for China is to be in accordance, so far as practicable, with the cxisting procedure prescribed for the consular court in China. The judge of this court has authority to modify and supplement said rules of procedure. ${ }^{1}$

Whether the statutes confer upon ministers authority to issue regulations dealing with any other matter than procedure in the courts has been questioned. The regulations for Japan transmitted in $18 \% 0$ to the Secretary of State, Mr. Fish, were found to contain a requirement that citizens should register at the consulates. Mr. Fish was of opinion that the statutes gave no authority for such a regulation and Are the regulations to contain only rules of procedure? Important work of consulsno power to enforce it judicially, and that the making of such a rule would be an assumption of the legislative prerogative. But Congress did not disapprove of these regulations. There is no doubt, however, that the opinion expressed by Mr. Fish has tended to restrain the ministers from exercising their power to make regulations; and this may partly explain how it is that the American system of foreign jurisdiction is lacking in many details essential to its efficiency, details which have been supplied in the British system as well by decrees of the ministers as by frequently issued Orders in Council. ${ }^{2}$

In the actual administration of the foreign jurisdiction the larger burden is carried by the consuls-general and consuls at a few leading ports. A considerable portion of the time of the consuls-general at Constantinople and Shanghai

cessor Mr. Reed regarded the proceedings as taken without the furisdiction and consequently a nullity, Ho. Ex. Doc. 29. p. 7 (vol. 8), 40th Cong.. 3d Sess.

1 Sec. 5.

2 Sen. Ex. Doc. 25, 3d Sess., 41st Cong.; Ho. Ex. Doc. 1, p. 570, pt. 1, 43d Cong., 1st Sess.; For. Rel. 1873, pt. 1, p. 570; MSS. Inst. Japan, 1870, printed in Wharton, Internat. Law Digest, vol. 1, p. 805.

It was the opinion of Mr. Bayard that Rule XV of the Regulations of 1864 for China, which related to limitations of actions, was to be regarded 'as a rule of court,' and 'not as a statutory mandate'; it could therefore be varied by the court as justice might require; MSS. Inst. China, April 27, 1887; quoted in Wharton, Internat. Law Digest, 
Relations of consular judiclal officers to thelr superiors

has heretofore been taken up with correspondence from other parts of Turkey and China relating to jurisdiction. ${ }^{1}$

The statutes restrict the exercise of judicial authority to the ministers, consuls-general, vice consuls-general, ${ }^{2}$ consuls and vice-consuls. Whether a foreigner holding one of these offices, as that of vice-consul, may exercise judicial authority, the statutes do not declare. The treaty of 1830 with Turkey states in its second article that the United States may appoint citizens to be consuls or vice-consuls in that country. ${ }^{3}$ Presumably the vice consuls-general and vice-consuls are to exercise judicial functions only in the absence or inability of their superior officers, or when specially instructed so to do." The term 'minister' in the Act of 1848, which the present statutes resemble, was thought by Attorney-General Cushing to include the secretary of legation and the chargé d'affaires ad interim when such official was invested with and exercising the principal diplomatic functions. ${ }^{5}$

Appendix, p. 882 ; see also. ibid., p. 972 , which discusses the principle of statutes of limitation as related to principles of international law.

In U. S. $v$. Fullert, decided in 1886 , in the consular court at Kanagawa, Japan, it was held that the regulations had created no new rights unknown to the laws and that they were intended merely to aid the administration and execution of existing laws; Scldmore, $U$. $\mathbf{S}$. Courts in Japan, p. 238.

In U. S. v. Maid, decided in 1902, in the U. S. District Court, S. D., Callfornia, it was held that a criminal offense against the United States could not be predicated of the violation of a requirement imposed only by rules or regulations of one of the executive departments of the government, 116 Fed. Rep. 650; this was upheld in U. S. $v$. Blasingame, 116 Fed. Rep. 654

1 There has been nothing in the American system, however, like that which existed in the German system in China in 1868, when the German consul-general at Shanghai virtually decided cases upon evidence taken by deposition before a German consul at a distant port; Dipl. Corr. 1868, pt. 1, p. 559.

2 The words 'vice consul-general' were inadvertently omitted from Sec. 4130 in the first edition of the Revised Statutes; Wharton, Internat. Law Digest, vol. 1, p. 809.

3 Martens says it was formerly customary, for France at least, to appoint subjects of the Porte as consular officers in Turkey; Das Consularwesen, p. 212.

The Chinese objected to having merchants act as consuls because merchants were regarded in China as beneath officlal rank and, indeed, as very low in social standing; Dipl. Corr. 1863, pt. 2, p. 843.

- Rev. Stat., Sec. 1674.

s Opin. Atty-Gen. 511. It was not until 1857, when the foreign lega- 
In the absence of the consul at Amoy, China, in 1894, the care of the interests of the consulate was transferred, with approval of the legation, to the acting consul for Germany at that port; and while thus in charge of the consulate, the Actlng consuls have no judiclai authority acting consul tried an American citizen for forgery, found him guilty and sentenced him to fine and imprisonment. The minister at Peking instructed the acting consul to suspend proceedings until it should be decided by the Department of State whether, as acting consul, he had been clothed with judicial authority. The Department gave instructions that no such office was known to our law as that of acting consul and that no persons were invested by the law with judicial authority except those who held the offices named in the Revised Statutes, Section 4130, as ministers or consuls. ${ }^{1}$

The friendly and unofficial interchange of assistance between consulates of one and another nationality, as between American and British consuls in the interior of Turkey, can in no wise involve a transfer of judicial authority. ${ }^{2}$

tions were first established at Peking, that the diplomatic representative of the United States bore the titie of 'envoy extraordinary and minister plenipotentiary'; from 1844 to 1857 he had the title of 'commissioner plenipotentiary', and only transcated business through the agency of the several viceroys in the provinces; 7 Opin. Atty-Gen. 228.

1 For. Rel. 1894, p. 139. It was the opinion of Attorney-General Miller that the government was in duty bound to protect the public, as far as it might reasonably be expected to do so, against the exercise of even merely voluntary consular functions by persons not regularly appointed consuls, and that no person not clothed with authority by the appointing power of the United States could lawfully executo the duties of a public officer.

In U. S. v. Mosby, 133 U. S. 273 , a distinction between the official and unofficial services of John S. Mosby, American consul at Hongkong from 1879 to 1885 , was shown.

Instances of friendly action on the part of British consuls in Turkey, but involving no question of judiciai authority, are given in For. Rei. 1882, p. 495, 498, 501, 503, 515: and in Bulgaria, For. Rel. 1893, p. 656.

${ }^{3}$ Before the extension of cables and telegraph lines to the East the suspension or removal from office of consular officers by the minister or consul-general was not unknown; as to China, see Dipl. Corr. 1864-5, pt. 3, p. 420, and Sen. Ex. Doc. 22, p. 1373 (vol. 9), 35th Cong., 2d Sess.; as to Egypt, see Dipl. Corr. 1864-5, pt. 4, p. 405 . In 1877 the minister to China relieved the consul-general from performing the functions of his office at Shanghai and, upon charges preferred by the minister, the consul-general was suspended by the President; Ho. Misc. Doc. 10, p. 1-43 (vol. 1), 45th Cong., 2d Sess. 
Relation between consuls acting as judges and other execu-

tive

officers
Relations of consuls to the Department of State in their judicial functions

Although consular officers are primarily officers of the executive branch of the government and are as such not only subject to instructions from their superiors but may even be suspended or removed from office by them, it should be observed that the statutes very definitely prescribe what cases are to be heard and decided by the consul sitting alone, for what cases the consul may summon associates to sit with him on the trial, and what cases may be appealed, thus fixing very precisely the distinction that in the exercise of their judicial authority consuls are not to attempt to obtain virtual decisions of cases by reference of them to their superior officers for instructions. A minister will refrain from giving an opinion on the merits of a case which might subsequently come before him upon appeal, and the Department of State does not control a consul acting judicially. But the reference of points of difficulty to their superiors for the expression of opinion has come to be one of the distinctive features of the American system of consular jurisdiction and is the more necessary on account of the lack of full and precise statutory provisions. ${ }^{1}$

The Secretary of State has no judicial authority except when there is no minister in the oriental country, yet this restriction has not been regarded as precluding the Secretary from giving instructions in explanation of the meaning of the treaties and the nature of usages existing in a particular country, or from obtaining legal opinions either in his own Department or in the Department of Justice ${ }^{2}$ regarding the law pertaining to the administration of the system of consular jurisdiction; and that such executive instructions may be cited in a court of justice, as showing both the rules of international law and the local usages at any particular consulate, has been the opinion pronounced by the federal courts, including the Supreme Court. ${ }^{3}$ Thus it happens that while these instructions in nowise relieve

\footnotetext{
${ }^{3}$ For. Rel. 1874 , p. $660,668$.

${ }^{2}$ A reference table of opinions rendered by the Attorneys-General relative to the foreign jurisdiction is printed infra, Appendix XI-2.

s Daniese v. Haie, 91 U. S. 13, 20.
} 
the consul of his responsibility as judge in particular cases, the voluminous oriental correspondence in the Department of State has become the principal record of opinions upon difficult points in the jurisdiction, and the annually printed volumes of the Foreign Relations series are the most available source of information as to these opinions. ${ }^{1}$

In keeping with the greater responsibilities of consuls in oriental countries are their greater immunities from the

Consular $1 \mathrm{~m}$. munities local jurisdiction. ${ }^{2}$ These are not diplomatic immunities, however. They are simply special privileges named in the treaties or arising from usage. By issuing an exequatur to him when he enters upon the execution of his official duties the oriental government recognizes that the consul possesses the international law prerogatives of his office as well as the particular prerogatives vouchsafed to him in the treaties. The consul is in no manner amenable to the native government; he cannot be taxed except upon property that does not pertain to his consular establishment; he cannot be arrested; his person and his domicil are inviolable; and these immunities are shared by the members of his family and by those who regularly assist him in the business of the consulate.

The relations of the consular officials with the native authorities were for many years a subject of negotiation at Peking. They were fully discussed in the conferences of the ministers to China in 18\%9. A similar question, that of the right of audience of the foreign ministers before the Emperor of China, was at the same time prominent. The result was that the predilection of the Chinese for certain forms and ceremonies was gratified, so far as consistent with recognition of the equality of the western governments with the government of China and so far as the con-

\footnotetext{
1 There is no special collection of decisions of consular courts, and the few written opinions of consular judges are not consulted by their successors to much extent. The newspapers at the leading ports print many of the decisions. The North China Herald and Supreme Court and Consular Gazette of Shanghai has for many years published the British, the American and other consular court decisions.

${ }^{2}$ As to the limited immunities of dragomans, cavasses and consular assistants and guards in general, see infra, p. 84-5.
}

Relations with offlcials of the local government 
venient dispatch of business permitted. The proper observance of these forms and ceremonies has often determined the success of an undertaking. It is believed, however, that the insistence upon punctilious observance of such formalities is decreasing. ${ }^{1}$

Con-

aular districts

Respecting the relations of consuls one to another in the exercise of their judicial functions it may be first remarked that the extent of country embraced within any consulate is defined under authority given to the President by Section 1695 of the Rerised Statutes. ${ }^{2}$ The treaties grant exemption from native jurisdiction throughout the territory

1 The rules of $18 \$ 0$ for correspondence between the consuls and the
provincial authorities are given in For. Rel. 1881, p. 205, 219; see also
For. Rel. 1880 , p. 185,272 . The suggestion that much of the correspond-
ence might be done in the English language was approved by the
minister, Ir. Seward, in For. Rel. 18 80 , p. 288 .
There was long a need of competent interpreters; For. Rel. 1879, p. 203, 234; 1880, p. 144; see also Dipl. Corr. $1866-7$, pt. 1, p. 479.

In earlier years the foreign ministers dealt directly with the taotais or governors of the provinces. One of the ministers, Mr. Parker, appears to have visited the consulates at regular intervals; Sen. Ex. Doc. 22 (vol. \$, 9), 35th Cong., 2d Sess.

A full documentary history of the audience question is given by $\mathbf{M r}$. Denby in For. Rel. 1891, p. 355, 367, 455. It is said that in former times Russian ambassadors were granted audience, and that the ambassador of Peter the Great, Count Isnailof, was received on November 29,1720 . The foreign ministers were not in residence at Peking until 1857. Their first audience did no occur unil 1873 and it was en masse. Shortly afterwards four European ministers were received separately. From that time until 1831 no audience was accorded, and in that year the Chinese government proposed an audience en masse. This led to a conference and the consequent acceptance of separate audiences. See also For. Rel, 1873, p. 194-201, and Wharton Internat. Law Digest, Appendix, p. $\$ 81$. A memorandum of the ceremonial to be followed upon occasion of audiences is printed in For. Rel. 1901, Appendix, p. 338 .

The Dutch superintendents of trade at Nagasaki, Japan, had been periodically brought to Yedo, rather to pay homage than obtain audience. The first accredited foreign representative to be received at the residence of the Shogun or Tycoon was the American minister, Townsend Harris. This occurred in 1857 and was marked by the greatest care as to ceremonies in honor of the minister and of his government. The foreign ministers were first received in a body on the Japanese New Year's Day, February 10, 1872; For. Rel. 1872, p. 321; 1879 , p. 620 .

A copy of the regulations for the diplomatic and consular service of China is glven in For. Rel. 1877, p. 85.

2 The Consular Regulations of 1\$96, Par. 30, give the general rule that the limits of a consulate embrace the territory nearer to the official residence of the consul than to the residence of any other consul 
belonging to the oriental state and it would seem reasonable to infer that the foreign jurisdiction would be conterminous with those boundaries including the coast waters. In the Ross case the court held that the harbor of Yokohama was within the district over which the jurisdiction of the consul extended.

It was held in Winn $v$. Hill, whether in the court of the minister or not does not appear, that no power to change the venue of a cause was given to consular courts in Japan either by statute or by regulation, that no cause could be remanded by one consul to the jurisdiction of another, and that the consul-general had no power to authorize or compel another consular officer to leave his consulate and come to Yokohama to act judicially. ${ }^{1}$

Passing to the remaining leading features of the statutes it may be noted that no questions concerning the utility of or frequency of resort to referees for the settlement of controversies appcar in the public documents. The same is true of cases heard and decided by consuls sitting without associates on the trial, yet a large number of cases are tried in this manner, many of them being minor criminal offenses such as are tried before justices of the peace in the United States. Concerning associates with the consular judge, it was held in Wertheimer $v$. Hoeflich, at Yokohama, in 18:0, that if a person whose name does not appear in the consular lists of associates approved by the minister, acts as associate, the circumstance is sufficient to vacate the trial and set aside the judgment in the case. ${ }^{2}$ It was also decided at Yokohama in U. S. v.Ross in 1880 and in U. S. v. Fullert in $1886^{3}$ that associates are in duty bound to decide both as

within the same alleglance, and state that this rule is to be followed when specific instructions have not been given.

At Ningpo, China, In 1856, Charles Jackson, an American seaman shot another American seaman. He was put in irons on the ship Levant of the same nationality and brought to Shanghai, where. with approval of the commissioner, he was tried and sentenced, notwithstanding there was a consulate at Ningpo at the time; Sen. Doc. 22, p. 888, 896, 912, 1013, (vol. 9), 35th Cong., 2d Sess.

1 Scidmore, U. S. Courts in Japan, p. 245.

Ibid., p. 204.

s Ibid., p. 205.

Qual1fication as associate

Associates to decide as to fact and as to law 
Attor- to questions of fact and as to questions of law. Attorneys neys

Jurisdiction of the minister

Cases implicating consular

employees not citizens of the United States were admitted to appear before the consular judge by courtesy, but only as agents on behalf of the litigants. ${ }^{1}$

That the Act of 1848, the language of which in this respect is repeated in the Revised Statutes, contemplated that the jurisdiction of the ministers, except in capital cases, should be solely appellate, was pointed out by AttorneyGeneral Cushing, in an opinion rendered in $1855 .{ }^{2}$ In 1874 the minister to Japan, Mr. Bingham, declined to give an opinion upon a case which from its nature might subsequently be appealed to the court in which he should sit as judge. $^{3}$ In 1882 the American minister to Japan held in E.r parte O'Neil that in refusing an application for a writ of habeas corpus for a prisoner confined under sentence of a consular court, a judgment had not been rendered in the exercise of either original or appellate jurisdiction and that in consequence no appeal from this ruling would lie to the circuit court in California. ${ }^{4}$ In Winn $v$. Hill, decided at Kanagawa in 1882, it was held that the statutes had not given power to the Department of State to revise a judgment pronounced in a consular court. ${ }^{5}$

The provision that where a consular officer is interested either as party or witness the minister is to have original jurisdiction was held by the Department of State not to pertain to a marshal or jailor. ${ }^{6}$ Section 4130 of the Revised Statutes includes under the term consul, 'consul-general, vice consul-general, consul or vice-consul'; this section, however, appears to refer only to officers upon whom judicial authority is conferred. Other persons connected with the consulates are therefore justiciable in the consular courts.

\footnotetext{
Meiklejohn $\%$ Gring, decided at Yokohama in 1886, Scidmore, U. S. Courts in Japan, p. 206.

27 Opin. Atty-Gen. 507. By act of June 30, 1906, the jurisdiction of the minister to China is impliedly transferred to the United States court for China; Sec. 1, 2.

- For. Rel. 1874, p. 660, 668.

- Scidmore, U. S. Courts in Japan, p. 201.

- Ibld., p. $203 . \quad$ For. Rel. 1892, p. 113, 123.

' Section 1674 includes under the term 'consular officer' none others
} 
It was also held by the Department that the necessity of summoning an acting consular agent as witness did not so involve a consular officer in the case either as party or witness as to require under the statute that the minister exercise original and exclusive jurisdiction. ${ }^{1}$

There appear to have been only six cases appealed from consular courts in China and Japan to the district court in California. $^{2}$ Of these only three were reported cases and two of these three, the case of the Steamer Spark $v$. Lee Choi Chum, in $1872,^{3}$ and the case of Tazaymon $v$. Twombly, in $1878,{ }^{4}$ were found to have been irregularly appealed and were dismissed. The third case, that of The Ping-On $v$. Blethen, in 1882: ${ }^{5}$ resulted in the statement of an opinion that the provisions of Section 4107 of the Revised Statutes, which make the judgment of the consul final when concurred in by his associates and allow an appeal to the minister when there is a difference of opinion, refer only to cases in which the matter in dispute does not exceed $\$ 2,500$, the provisions in regard to appeal to the minister being necessarily subordinated to the provisions for a system of appeal to the circuit court in California. Similarly it was held in Nee Chang Mow and Co. v. George and George, decided at Shanghai in 1903, that an appeal in a suit involving more than $\$ 2,500$, United States gold, would not lie to the minister. ${ }^{\circ}$

than consuls-general, consuls, commercial agents, deputy consuls, rice-consuls, vice-commercial agents and consular agents.

1 For. Rel. 1879, p. 987, 1010, 1012.

$2 \mathrm{Mr}$. Southard Hoffman, clerk of the circuit court for the northern district of California, states that the records show three unreported cases, appeals from the consular courts in Japar, namely: No. 1269, Yenomoto Rukubie v. Pacific Mail Steamship Co., appeal ordered dismissed in 1874, no opinion; No. 1342, Finance Department of the Imperial Government of Japan v. Pacific Mail Steamship Co., record on appeal filed in 1875, appeal ordered dismissed in 1878 for want of prosecution; No. 2614, Mitsu Bishi Mail Steamship Co. v. Pacific Mail Steamship Co., motion to dismiss appeal denied and appeal of consular court affirmed in 1882, no opinion.

31 Sawyer 713. The opinion of Mr. Justice Sawyer sets forth the requisites of an appeal.

4 Sawyer 79.

511 Fed. Rep. 607.

- North China Herald, vol. 1xx, p. 137, January 21, 1903. 
Constitutionality of the jurisdiction

It was to be expected that an anomalous system of jurisdiction which, although administered under circumstances that made any fully satisfactory methods of justice very difficult, denied to American citizens or failed to provide for them the forms of justice to which they were accustomed at home, would be challenged as unconstitutional. The point of constitutionality has been argued impromptu in the Senate $^{1}$ and has been a subject of decision in the state and federal courts in the United States and in the consular courts in China ${ }^{2}$ and Japan as well.

In debate on the annual consular and diplomatic appropriation bill, January 7, 1S81, Senator Matt. Carpenter of Wisconsin, moving to strike out the paragraphs relating to rent of a prison for American convicts in China and for wages of keepers, care of offenders, and expenses, declared the whole American system of foreign jurisdiction in the Orient boldiy unconstitutional, and said: "I deny that the Government of the United States can exercise any authority derived from anybody or anything except the Constitution of the United States. I deny that the monarchy of Great Britain can clothe us with powers denied by the Constitution; I deny that the Emperor of China can do any such thing; and although it be to exercise power upon our citizens, I deny that our Government as a Government can do it. . . When you get into a State Legislature there anything within the general province of legislation may be done if it is not forbidden by the State or Federal Constitution; but when you come to consider any power of Congress it is not enough to show that it is not forbidden in the Constitution. You must be able to point out the clause that confers the power." "When you come to our power to do what China is willing we should do, you must point to some provision in the Constitution which gives us that right."

Senator Hoar of Massachusetts briefly showed the inexpediency of doing away with the usual appropriations for the exercise of our foreign jurisdiction. "I understand," said he, "that the jurisdiction of our consular offlcers or ministers in foreign countries, especially in Asiatic countries, for the trial of offenders for grave offenses is not under any authority conferred by the Constitution of the United States, but it is under the authority conferred by the governments where they reside." And Senator Hill of Georgia said: "In my judgment this whole question of the protection of our citizens in foreign countries is vested in the Government of the United States under the treaty-making power, not under the judicial power or any of those other powers relating to the government of citizens in this country; and I think that in all our relations with foreign governments the United States Government is just as much a nation as England or France." Congressional Record, vol. 11, pt. 1, p. 409-16, 46th Cong., 3d Sess.

2Shanghai, 1864, case of J. Buckley, on trial for murder, T. B. Eames, attorney for defendant; Dipl. Corr. 1864-5, pt. 3, p. 400, 440, 474, 478; see a statement of the facts in this case in In re Stupp. 11 Blatchford, 148 . 
It was contended in Forbes $v$. Scannel, ${ }^{1}$ in the supreme Forbes $v$. court of California in 1859 , that Congress, in legislating Scannel, directly upon the persons and property of American citizens under anthority derived from China, had exceeded its powers under the constitution; that the authority conferred upon ministers to make regulations was a delegation of legislative power, and therefore unconstitutional; that under the constitution no person could be held to answer for capital or infamous erimes without the presentment or indictment of a grand jury, whereas in the consular courts, the consul, an executive officer, ordinarily brought the indictment and acted alone as prosecuting attorney, judge and jury.

The opinion of the court delivered by Mr. Justice Baldwin contains the following passage:2

It would require an extremely clear case of repugnancy to the Constitution of the United States to justify us in holding uncon. stitutional such a power of protection to American citizens-a power alike essential to the maintenance of friendly relations with a state like China and to secure the rights of our people there, and one, moreover, so long recognized as well by our own government in other instances, as by other Christian powers in their intercourse with such nations.

The general authority given to Congress to regulate commerce with foreign nations could, probably, find no more useful or appropriate means of exercise than in treaties and laws withdrawing our citizens domiciled in unchristian nations from the jurisdiction of such governments, and confiding their rights of property and persons to judicial officers of their own country, administering, under responsibilities to a common government. laws with the general spirit and principles of which those citizens are familiar. That government would be weak indeed which could not, in this peaceful and un. objectionable mode, with the assent of the foreign power, exercise this wholesome protection and restraint over its citizens abroad.

\footnotetext{
${ }^{1} 13$ California 242, 250, 263.
}

213 California 242, 281. 
In the case of Ross, before the Supreme Court in 1890, counsel argued that the legislation which was intended to carry the treaties into effect should have provided the same protection and guarantees in Japan against undue accusation and unfair trial which are secured by the constitution to citizens within the United States. Upon this argument, after stating the general grounds of extraterritoriality in oriental countries, the court held as follows, Mr. Justice Field delivering the opinion $:^{1}$

By the Constitution a government is ordained and established "for the United States of America", and not for countries outside of their limits. The guarantees it affords against accusation of capital or infamous crimes, except by indictment or presentment by a grand jury, and for an impartial trial by a jury when thus accused, apply only to citizens and others within the United States, or who are brought there for trial for alleged oifences committed elsewhere, and not to residents or temporary sojourners abroad. . . . The framers of the Constitution, who were fully aware of the necessity of having judicial authority exercised by our consuls in non-Christian countries, if commercial intercourse was to be had with their people, never could have supposed that all the guarantees in the administration of the law upon criminals at home were to be transferred to such consular establishments, and applied before an American who had committed a felony there could be accused and tried. They must have known that such a requirement would defeat the main purpose of investing the consul with judicial authority. While, therefore, in one aspect the American accused of crime committed in those countries is deprived of the guarantees of the Constitution against unjust accusation and a partial trial, yet in another aspect he is the gainer, in being withdrawn from the procedure of their tribunals, often arbitrary and oppressive, and sometimes accompanied with extreme cruelty and torture.

With regard to this case an eminent authority on conagency stitutional law has observed that the principle involved is "simply that of an immunity granted by the territorial sovereign of Japan to the citizens of the United States while sojourning in Japan. It is probably true that this practice

1140 U. S. 453,464 . As to Ross's nationality see infra, p. 87 and ibid. note 3 . 
of consular jurisdiction in foreign lands is a relic of the Professor mediaeval idea that law is personal-that is, racial or na- opinion tional-and follows the individual wherever he may go. But the modern principle is that law is territorial, and that all departures from this principle are the exceptions which make the rule manifest. We must, therefore, reconcile the existence of these exceptional immunities with the principle of territorial sovereignty; and this can be done only by regarding all authority exercised within the sphere of the immunity as proceeding from, and administered for, the territorial sovereign, but administered by the countrymen of the party or parties concerned, and administered according to such methods as they or their home government may devise." 1

This theory is, in a word, that of agency: a consul in Turkey or China exercises jurisdiction as an agent of Turkey or China; the source of his authority as a judge is not the United States, but the oriental power, which has, through treaty stipulation or long standing usage, made the grant of jurisdiction; the laws and regulations provided by the American government for controlling the exercise of consular jurisdiction are virtually provided in behalf of the oriental government. From the theory of agency it follows that the federal government is not restrained by the Constitution of the United States from providing for the trial of citizens sojourning in China or Turkey in consular courts, which cannot, under existing law, extend to such citizens the same immunities as they enjoy in their own country. "All that the court said, in the Ross case, was that "the Constitution can have no operation in another country,' and that the government was not established for countries outside of the United States."

It may further be observed that Congress in providing for the government of the territories of the United States has found it impracticable to establish systems of justice in

\footnotetext{
1 Burgess, Government of Distant Territory, Political Science Quarterly, vol. 14 (1899), p. 9.
} 
courts in the territories

Other constitutional grounds

Jurisdiction under the power to make treaties which all of the essential rights vouchsafed by the constitution to citizens residing in the states could be preserved. The territorial courts are maintained under the third section of Article IV of the Constitution, which confers power upon Congress to make all needful rules and regulations respecting the territory and other property of the United States. Upon this basis much legislation has been enacted, the necessity for which the framers of the Constitution could not possibly have foreseen and which, though it has qualified, adapted and restricted the exercise of certain civil rights in those territories, the Supreme Court has upheld as constitutional. ' Similarly, the legislation for carrying into full effect the treaties of extraterritoriality could not possibly have provided for citizens in the Orient the same rights they enjoy at home, and the analogy is the more apparent when it is recalled that neither the courts in the territories nor the consular courts are federal courts under the third article of Constitution, that they cannot be said to exercise the 'judicial power of the United States,' and hence that they cannot be regarded as subject to the constitutional limitations of the courts of the United States.

Again there are constitutional grounds for these forms of foreign jurisdiction in the eighth section of Article I which gives Congress power to regulate commerce with foreign nations, and in subsequent clauses of the same section which give Congress power to enact laws to define and punish offenses against the law of nations and to carry into execution all powers vested by the Constitution in the government of the United States or in any department or officer thereof.

Another and a very strong basis of constitutionality for the statutory system of foreign jurisdiction is contained in Article II, Section 2, which declares that the President shall have power, by and with the advice and consent of the Senate, to make treaties and that he shall nominate and by

${ }^{1}$ Canter's case, 26 U. S. 546; Hawaii ¿. Mankichi, 190 U. S. 217; U. S. ¿. Dorr, 195 U. S. 148; Rasmussen $i^{2}$.'. S., 197 T. S. 516. 
and with the consent of the Senate shall appoint ambassadors, other public ministers an consuls, and in Article VI, which declares the Constitution, and the laws made in pursuance thereof, and all treaties nade or which shall be made under the authority of the Unitul States, to be the supreme law of the land.

Among the several earlier and later Acts of Parliament relating to foreign jurisdiction, that of 1843 is notable as being the first in which fundamental propositions of law British foreign juriswere set forth looking to the control of such jurisdiction in its entirety. ${ }^{1}$ There were already in existence certain acts applicable to jurisdiction in particular countries; ${ }^{2}$ jurisdiction in Japan had at least been granted to the East India Company; and jurisdiction had prevailed in Turkey under the charter of the Levant Company until its dissolution in $1825 .^{3}$ In 1826 the legality of the jurisdiction of consuls in Turkey was doubted by the law officers of the Crown, and eventually in the Act of 1843 Parliament declared the leading principles of law in conformity with which the entire foreign jurisdiction should be regulated.

This and subsequent enactments were consolidated in the Foreign Jurisdiction Act of 1890 , whicll is still in force." The Act declares that "whereas by treaty, capitulation, grant, usage, suffrance, and other lawful means," the Crown "has jurisdiction within divers foreign countries," "it is an!l shall be lawful for" it "to hold, exercise and enjoy any jurisdiction" which it "now has or may at any time hereafter have within a foreign country in the same and as ample a

1 The leading authorities on British foreign jurisdiction are: Hall, Forelgn Powers and Jurisdiction of the British Crown, London, 1894; Piggott, Exterritoriality-The Law Relating to Consular Jurisdiction and to Residence in Oriental Countries, London, 1892; Tarring, British Consular Jurisdiction in the East, London, 1887. Hertsiet's Commercial Treaties, vol. xvi, p. 232-42, gives an excellent index of treaties, acts and orders relating to foreign jurisdiction.

2 Hildreth, R., Japan as It Was and Is, Boston, 1855, p. 170.

a Certain such acts are named in the act of June 10, 1825, by which the Levant Company's charter was rescinded and the powers exercised under it were taken over by the general government; Brit. and For. State Papers, vol. 12, p. 531.

453 and 54 Vict., c. 37. 
Provisions of the Foreign $\mathrm{Ju}-$ risdiction Act of 1890

manner" as if it had acquired that jurisdietion "by the eession or conquest of territory." In this language, while recognizing the prerogative of the Crown in the making of treaties and in respect to foreign relations in general, Parliament gives or confirms certain legislative powers exercised or to be exercised by the Crown in Council in regulation of the foreign jurisdiction. ${ }^{1}$ The Act further declares that "an Order in Couneil made in pursuance of this Act shall not be, or be deemed to have been, void on the ground of repugnancy to the law of England unless it is repugnant to the provisions" of an Act of Parliament or of regulations made under it, which extend to British subjects in the particular country affected by that Order in Couneil. And "every Order in Council made in pursuance of this Act shall be laid before both Houses of Parliament forthwith after it is made" and "shall have effect as if it were enacted in this Act." "Where a foreign country is not subject to any government," from which this jurisdiction might be obtained, the Crown "shall by virtue of this Act have jurisdiction" over British "subjects for the time being resident in or resorting to that country," and that jurisdiction shall be within the provisions of this Act. "If in any proceeding, civil or criminal, in a court" in British dominions or held under British authority "any question arises as to the existence or extent" of British jurisdiction "in a foreign country, a Secretary of State shall, on the application of the court," send his decision on the question and "his decision shall for the purposes of the proceeding be final." "Every act and thing done in pursuance of" the jurisdiction "in a foreign country shall be as valid as if it had been done according to the local law then in force in that country." At some length it is declared under what forms of law the Crown in Council may authorize the transfer of criminal offenders from foreign countries to British possessions and may provide for their trial within those possessions. The Act also declares in what measure consuls or others may be

\footnotetext{
1 Hall, Forelgn Jurisdiction, p. 9; Piggott, Exterritoriality, p. 26.
} 
held liable for neglect or default in exercising the jurisdiction. It declares the power of the Crown in Council to make any law that may seem meet for the government of British subjects being in any vessel at a distance of not more than one hundred miles from the coast of China or of Japan; and it includes among British protected subjects all the subjects of the several princes and states in India. To a certain extent it repeals other acts mentioned in an appended schedule, and authorizes the Crown in Council to amend, or revoke, certain other acts, if it sees fit.

The foregoing sketch of the principal Act of Parliament respecting foreign jurisdiction is enough to indicate how little direct legislation has been included in it and to suggest that in confirming the Orders in Council made or that The Or. ders in Council their number should be made in pursuance of the act and in conformity with it, Parliament designed to leave practically the entire provision for and regulation of the foreign jurisdiction to the Crown in Council. As a rule, each of these Orders in Council applies to one country alone. The number of the Orders has been large, both because of the many countries where the jurisdiction has been exercised and because of frequent revisions. The more recent Orders are muck longer and in greater detail than the earlier. They contain in elaborate form the adaptations of English law which experience has shown to be necessary for the protection and control of the long-established and wide spread interests of British subjects residing or trading in the Orient. In general their field is no less extensive than that occupied by the other and somewhat similar Orders in Council for the government of the crown colonies. They have much wider scope and greater detail than the statutes upon which the American system rests. For example, they limit less narrowly the power of the ministers to make regulations for the observance of the treaties in certain exigencies and for the peace, order and good government of British subjects in the oriental country; they grant to the minister a right of 
pardon which he may extend in certain instances to criminal offenders; and they make compulsory the registration of British subjects at the consulates. ${ }^{1}$ Another marked feature of the British system of foreign jurisdiction in comparison with the American consists of its highly perfected system of appellate jurisdiction. In some countries an appeal lies to the court of the minister, but in others, as in China and Turkey, it lies to a supreme consular court, as at Shanghai or Constantinople. Certain appeals are allowed to courts of superior standing in British colonial possessions as to Hongkong, Bombay, the Straits Settlements, Malta or Gibraltar, and from such courts to the Privy Council. The supreme court of the colony of Hongkong has been intimately connected with the administration of justice in consular courts in China and Japan. ${ }^{2}$

The French system of forelgn furisdiction

Another system of foreign jurisdiction more highly perfected than the present American system, is the French. The principal legislative acts for the control of this jurisdiction are those of 1681, 1798 and 1836. There have been many supplementary and amendatory acts, but the royal edict of $17 \% 8$ still remains the fundamental law in respect to civil jurisdiction as the law of 1836 remains the fundamental law in respect to criminal jurisdiction, while both rest upon the provisions of the royal edict of 1681. That the French system was developed so much earlier than the English was due to the priority and early predominance of French interests in the Levant. ${ }^{3}$

\footnotetext{
${ }^{1}$ Piggott, Exterritoriality, p. $11 \%$.

2 Norton-Kyshe (appointed registrar of the supreme court at Hongkong In 1896), History of the Laws and Courts of Hongkong, 2 vols., London and Hongkong, 1898.

${ }^{3}$ Two of the leading authorities on French consular jurisdiction are Féraud-Giraud, De la juridiction française dans les échelles du Levant et de Barbarie, $2 d$ ed., 2 vols., Paris, 1871, and De Clercq and De Vallat, Guide pratique des consulats, 5th ed., 2 vols., Paris, 1898. Féraud-Giraud contains annotations upon the principal legislation and upon decided cases. De Clercq and De Vallat give the text of legislation and many other documents pertaining to the jurlsdiction.

As to the law in force see Féraud-Giraud, vol. 2, p. 227-439, and De Clereq and De Vallat, vol. 1, p. 526-606.
} 
From the sixteenth far into the nineteenth century there origin existed many distinct communities of French merchants in the Turkish dominions, the political organization of which eign municipaliwas provided in and controlled by royal edicts and other laws. Each of these communities or groups of French in one of the échelles du Lerant ${ }^{1}$ was called a nation. Each nation was to be assembled by the consul at least annually for deliberation and action upon matters pertaining to its welfare. In December of each year-so it was provided in a royal ordinance of 1781 - the nation was to elect deputies whose function it was to assist the consul in general administration of the affairs of the community. Thus the nation of former times, with its deputies, bears much resemblance to the present foreign municipalities in China and indeed seems to have formed a prototype for them. ${ }^{2}$

A second institution which originated in the French system of foreign jurisdiction is that of having the consular judge aided by assessors. By the ordinance of 1681 the consular tribunal for all cases of whatever nature or importance was to consist of two deputies and four notables or leading merchants, making, with the constl, a court of seven judges. The difficulty of finding as many such assessors as the law required led to the reduction of the number by edict of 172 from six to two, and either deputies or notables might be summoned by the consul. But if notables were summoned they were to be the two that had been appointed by the French Minister of Foreign Affairs from a list submitted by the consul to hold the office of assessor for one year. The function of the assessors in the French system is to assist the consul in deciding both as to fact and as to law. ${ }^{3}$ From the French system the plan of having assessors has been adopted into the British and Ameriean systems.

\footnotetext{
1 The term ćchelles or ladder refers to the wharves or landing places of ships in the Levant.

2 Féraud-Giraud, Juridiction française, vol. 2, p. 67; De Clercq and De Vallat, Guide pratique, vol. 1, p. 328.

- Féraud-Giraud, Juridiction française, vol. 2, p. 270, 390; De Clercq and De Vallat, Gulde pratlque, vol. 1, p. 528, 563.
}

Development of the assessor system 
Appellate courts

Further development of the Ameri. can system
Like the British system, the French has special courts of appeal. From judgments in consular courts in the Levant, including the Barbary States, appeal lies to the court at Aix, near Marseilles; from China, Siam and Korea, to the court at Saigon, in Cochin-China. In fact the provisions for appeal to courts within the national territory are much more complete in the foreign jurisdictional systems of all the European states than they are in the American system. This is due in part, no doubt, to the proximity of these countries to the Levant; but in general the European consular systems, especially the German, have been subject to more frequent legislation in recent years than the American.

Consular jurisdiction, as administered by Great Britain and France, at least, is a system to which much legislative and executive attention has been given. If it is possible by prescribing minutely what the law is, by selecting trained men to apply it and by setting up superior courts of appeal with an ultimate review in difficult cases by the highest courts at home-if it is possible to make foreign jurisdiction adequate to the situation, then the many legislative acts, decrees, orders and opinions found in the public documents of France and England attest that all is being done by these two powers that can be done to make their systems of extraterritorial jurisdiction satisfactory and sufficient.

That the administration of justice in American consular courts has twice, once in 1848 and again in 1860, been, as a system, subject to action by Congress, and then without debate, is not to be taken as proof of the sufficiency of our existing legislation. In 1881 President Arthur stated in his annual message that changes in the system were desirable, and he transmitted an opinion of Secretary of State Blaine in regard to the direction which these changes might profitably take. ${ }^{1}$ Mr. Blaine's leading points were: that the existing statutes lacked clearness, precision and comprehensiveness and did not provide for the settlement of conflicts of

2 Sen. Ex. Doc. 21 (vol. 1), 47th Cong., 1st Sess. 
jurisdiction; that certain amendments could be introduced to remove unnecessary inconsistencies with the Constitution; and that men of legal training should be chosen for certain judicial offices independent of the consular system and not concerned with commercial affairs; and he recommended the establishment of a separate system of courts, at least in China, with an appellate court at Shanghai. After pointing out the increasing difficulties under the existing law, Mr. Blaine continued: "If, on the whole, the administration of consular justice abroad, in favor of American citizens, has worked with considerable regularity, utility and success, this result has been due rather to the right of extraterritoriality itself, and to the average common sense of business officers to whom the exercise of that right has been so broadly committed, than to the constitutionality or precision of the statutes. And it may be doubted whether the naked fact that an arbitrary and practically unlimited delegation of judicial powers has been followed in the main by a discreet use thereof, is a sufficient argument for the conferment of those powers, or their unmodified continuance for all time."

The year following, Mr. Frelinghuysen, Secretary of State, wrote to Mr. Windom, Chairman of the Foreign Relations Committee of the Senate, that an examination of the existing legislation and comparison of it with the legislation of Great Britain and France upon the same subject would "probably be sufficient to satisfy the committee low far the American in these foreign colonies fails to receive from his government the protection which is accorded to other foreigners." 1

${ }^{1}$ Sen. Misc. Doc. 89, p. 3 (vol. 1), 47th Cong., 1st Sess.

A long memorial sent to Congress in 1881 by American residents in Japan, praying for legislation modifying certain antiquated rules of common law in force under the foreign jurisdiction but already modifled by legisiative action in the several states of the union, read in part as follows: "For us there is no statute of frauds. There is no insolvency legislation. . . . Imprisonment for debt has not been abolished. The disabilities of women at the common law have remained unaltered. We have no statutes of limitations, and none providing for conditional bills of sale or chattel mortgages. In many other respects investigation will show how unfavorable is the legal status of a citizen of the United States residing here." Sen. Misc. Doc. 70 (vol. 1), 47 th Cong., 1st Sess.

Mr. Blaine's opinion of the American system 
Accompanying Mrr. Frelinghuysen's letter there was the Davis- O'Connor draft of a bill drawn by Messrs. Bancroft Davis and O'Conbill of nor for the Department of State. The bill contemplated creating three district courts for China, one at Shanghai, another at Tientsin and a third at Canton, a fourth district court for Japan and a supreme court at Shanghai, with appeals from consular courts to these courts instead of to the court of the minister or the United States district court in California. There was to be one district judge for China and another for Japan, each to have a clerk of court and an interpreter and to be occupied solely with judicial as distinct from consular commercial functions. The two judges and the consul-general sitting together in Shanghai or Yokohama were to constitute the supreme court for China or Japan as the case might be. The judges were together to make rules of court for the conduct of all causes in the consular and superior courts. The existing method of sitting with associates in the trial of certain cases was to be modified to the extent of requiring trial by jury of five citizens, or if five were unobtainable, then by three. But crimes punishable with death were to be tried and punished as under the present law. This plan of trial by jury included cases arising in Turkey also, and appeals in civil cases of more than one thousand dollars in value could be made to the consul-general at Constantinople. Many details insufficiently or not at all prescribed in the existing law, as of bankruptey, marriage, rights under international municipalities, rights in mixed cases, evidence, fraudulent transactions, inheritance, partnership, jury duty and many other points of difficulty which had arisen in the course of administering justice in the consular courts, were provided for in the proposed law. Finally, the Secretary of State and the AttorneyGeneral were authorized to prepare a code of practice to supply defects and deficiences in the existing remedies and to draw up regulations for carrying the act into effect; and the code and regulations when approved by the President were to have the force of law. ${ }^{1}$

${ }^{1}$ Sen. Misc. Doc. 89, p. 210 (vol. 1), 47th Cong., Ist Sess.; Ho. Rep. 2250 , p. $1-8,48$ th Cong., 2 d Sess. 
The bill was much modified by the Senate. Another bill was introduced in the House in 1884, but no action beyond receiving the report was taken. ${ }^{1}$

The consular service reorganization bills introduced in recent years by Senators Lodge and Morgan and Mr. Adams contained provisions requiring legal training of consuls in whom judicial authority would be vested.

The Act of April 5, 1906, reorganizing the consular service, only indirectly affects the exercise of extraterritorial jurisdiction. ${ }^{2}$

Early in the first session of the Fifty-ninth Congress a bill to create a United States court for China was introduced in the Senate. Late in March, 1906, Mr. Edwin Denby, of Michigan, introduced a bill in the House. Mr. Denby's Act of June 30 , 1906 , creating a U. S. court for large knowledge of American relations with China enabled him to persuade his colleagues of the necessity and advantage of creating the United States court for China.

The bill was reported in the Senate with much amendment. The great advantage of being advocated by Senator Spooner, with whom, as with Mr. Denby, officials of the State Department, the Solicitor, Dr. J. B. Scott, and others, were in frequent consultation, brought this legislation into the form it took in the Act of June 30, 1906. ${ }^{3}$ An appropriation for the salaries of officials of the new court and for other expenses was made in a separate Act of the same date. ${ }^{4}$

In the Executive Order of June 27, 1906, President Roosevelt embodied the requirement of legal training for consuls exercising judicial functions, thus facilitating the improvement of the service as planned by Mr. Secretary Root. ${ }^{5}$

\footnotetext{
${ }^{1}$ In 1904 Mr. H. H. D. Peirce, of the State Department, upon returning from a tour of inspection of Amerlcan consulates in Asia, prepared the draft of a brief bill to create a United States circuit court for China and Korea. It proposed that the laws of the District of Columbia be extended over citizens in those countries. Appeals were to lie to the supreme court of the Phillppines or to the clrcuit court of appeals at San Francisco. Report of October 29, 1904; without document number. Mr. Peirce's later report, December 15, 1904, confidential, was eventually printed in Ho. Doc. 665, 59th Cong., 1st Sess., p. 1-444

2 Printed infra, Appendix III-1. ${ }^{3}$ Printed infra, Appendix III-2.

4 The General Deficiency Act.

${ }^{5}$ The Order Is printed infra, Appendix III-3.
} 


\section{IV}

\section{LEGAL RIGHTS UNDER THE JURISDICTION}

The treaties of the various western powers with any oriental state bear a close resemblance one to another in their provisions regarding extraterritoriality, and the usages in a particular country have an almost entire uniformity under whatever national jurisdiction benefit of them is claimed; but in application of either or both treaties and usages to particular cases the divergent characteristics of each national jurisdiction appear.

The United States is one of the few powers the large extent of whose intercourse with the Orient has resulted in developing a fairly complete body of precedents and decisions, executive and judicial, relating to legal rights of individuals under foreign jurisdiction.

\section{I - NATIONALITY}

Seope of the term Amert-

So far as extraterritorial privileges are involved, American nationality includes all persons, whatever their civil status, who owe allegiance to the United States either as citizens by birth or by naturalization or as native inhabitants of the insular possessions, or as seamen on American ships, or as assistants or guards in legations and consulates, or, to a limited extent, as employees of American citizens in oriental countries.

It is held that citizenship acquired by naturalization gives 
an equal right to American protection abroad with citizenship acquired by birth, but there has been some difficulty in maintaining this doctrine in favor of naturalized citizens

Naturalized cit!zens of Turklsh origin. who have returned to the country of their former allegiance. The Turkish government has declared that Turkish subjects who have expatriated themselves without permission sinee 1869 , when a law of nationality was decreed, ${ }^{1}$ are not to be recognized as having the right to consular protection in Turkey or even of entering the country or remaining in it. ${ }^{2}$ It is believed, however, that the Turkish government has in no instance pressed an assertion of this elaim upon the sole ground of unauthorized expatriation. ${ }^{3}$ The practice of several European governments is not to naturalize an alien unless he proves that his change of allegiance has been permitted. ${ }^{4}$ The British Naturalization Act of $18 \% 0$ declares that the naturalization of an alien shall be withont force and effect when he returns to the country of his original allegiance unless by the laws thereof or by treaty between that country and Great Britain his change of status is recognized $5^{5}$ and an indorsement to this effect is made upon all British passports issued to aliens. ${ }^{6}$

The Turkish government has upon several oceasions permitted the wires and minor children of naturalized citizens to emigrate to the United States, and when, under the laws of the United States, the naturalization of the husband or father has effected also the naturalization of the wife and children, the permission to emigrate has been demanded as of right. ${ }^{7}$

1 Brit. and For. State Papers, vol. 67, p. 1251.

2 For. Rel. 1900, p. 938; see also For. Rel. 1871, 1886, 1892-1897 passim.

${ }^{3}$ For. Rel. 1895 , pt. 2, p. 1471.

- Hall, International Law, London, 1895, p. 247.

${ }^{5} 33$ and 34 Vict., c. 14.

- For. Rel. 1894, p. 762.

7 For. Rel. 1893, p. 591, 598, 603, 649, 666; 1894, p. 765; 1895, pt. 2, p. 1471; 1896, p. 924.

The effect of marriage upon the nationality of a woman in Turkey Is fully discussed by Salem, Jour. du drolt internat. prive, 1901, p. 936, and 1902, p. 79.

Marriage of a Chinese woman to a German was declared In an agreement in 1888 between the governments of the two countries to 
Restric-

tlons

upon

Jews in

Turkey

Incomplete naturalization ${ }^{2}$ and naturalization irregularly effected give no right to protection. Neither can intention to become a citizen be legally declared under the foreign jurisdiction nor can residence under that jurisdiction be counted as residence in the United States within the requirements of the naturalization statutes. ${ }^{2}$

It has been the policy of the Ottoman government to prevent the immigration into Palestine of Jews en masse who wish to establish themselves there as permanent colonists. The sojourn of Jewish travellers in Palestine has been limited to one month, extended in 1888 and later to three months. Another restriction has becn that of requiring Jewish purchasers of real estate in Palestine to subscribe to certain exceptional agrecments. Nany Jews from Europe and some from the United States have entered Palestine for travel or settlement under these conditions. The protest of the British government against these regulations took the ground that inasmuch as within its own territory it was protecting persons of every class and creed and thus in no wise causing an immigration of Jews into Turkey, it had additional reason for not admitting that Turkey possessed any right to exclude or restrict British Jews in the enjoyment of privileges guaranteed under the capitulations and treaties. ${ }^{3}$ The American protest, taking similar ground, declared that no conditions or distinctions could, at the instance of Turkey, be introduced into the passports issued to American citizens. ${ }^{4}$ Protection would, however, be with-

make the Chinese woman subject to German jurisdiction. Notwithstanding the statutory inhibition against the naturalization of Chinese, it was stated by Secretary of State Bayard that the agreement between Germany and China would probably "assist in determining the status, in China, of the Chinese wife of an American cltizen, assuming the marriage to be consensual and monagamous"; For. Rel. 18\$s, pt. 1, p. 349; see also p. 319, 347, 6\$3; and infra, p. 94.

' Cases in China, For. Rel. 1887, p. 190, 210; 1896, p. 91 . Cases in Turkey, For. Rel. 1885, p. $849,855$.

2 Application of Mr. Garglulio, dragoman of the American legation at Constantinople; For. Rel. 1893, p. 692, 701.

' For. Rel. 1888, pt. 2, p. 1590.

- Ibid., p. 1617, 1627. 
drawn from Jews permanently settling in Palestine, ${ }^{1}$ and restrictions upon the purchase of real estate applicable alike to native and to foreign Jews were not made a subject of protest. $^{2}$ The American representatives in Turkey have been instructed to remonstrate against any detention of baggage or other method of enforced guaranty against overstaying the three months' sojourn of American Jews in Turkey. ${ }^{3}$ The enforcement of rules against the Semitic colonization of Palestine was understood not to restrict the rights of bona fide travellers. ${ }^{4}$ The Anierican minister, Mr. Straus, stated that in justice and fairness to the Turkish government, its disposition to be liberal toward foreign Jews when no political complications had been involved must be admitted. ${ }^{5}$

The usual evidence of right to American protection is the possession of a passport, but the lack of one does not prejudice a claim to protection pending investigation. The issuance of passports to American citizens is by law left to the discretion of the Secretary of State. In foreign countries diplomatic officers have authority to issue passports under prescribed rules, and consular officers may also be specially authorized to issue them. ${ }^{6}$ The issuance of passports is, however, within certain limits, discretionary.

It is customary for persons who intend to travel in the interior of Turkey to obtain through a consulate special cerTurkish teskerebs tificates or permits, called teskcrchs, issued by the Turkish government. In 1898, at a time of apprehended revolutionary disturbances, there was some delay in granting these travel permits, but the right to refuse them was not claimed and under the stipulation of freedom of travel contained in the capitulations ${ }^{8}$ the right to refuse them, unless as a

${ }^{1}$ For. Rel. 1894, p. 752-64.

2 For. Rel. 1898, p. 1107.

s For. Rel. 1894, p. 752.

- For. Rel. 1898, p. 1092.

- Ibid., p. 1093.

- Rev. Stat., Sec. 4075.

7 For. Rel. 1898, p. 1095

- Capitulations of 1740 , Art. 20. 
necessary means of protection to the state, would not appear to exist.

Chinese travel certificates

Vise of passports by native offlials

For citizens intending to travel in the interior of China a special form of travel certificate has been authorized. Under the rules of May 1, 1890, travel certificates could be issued by consuls to citizens who had already attained passports or who had applied for them. For citizens with passports the travel certificates were made good for one year, for others, good only for the particular journey and not longer than one year. ${ }^{1}$ The earlier practice had been to issue all travel certificates only for particular journeys. The rule of the British treaty with China of 1858 that 'passports must be produced for examination in the localities passed through' is construed to mean that on proper demand by a proper official, as the magistrate of a chou or hien, passports must be exhibited, but that the traveller need not voluntarily show his passport nor go out of his way to hunt up an official for the purpose of showing it. ${ }^{2}$

If native officials visé a passport the effect is only to give convenient certification to other native officials. The Turkish regulations of February 9, 1884, required that passports of foreigners entering Turkey should bear the visé of an Ottoman minister or consul, and that within six months of arrival in Turkey the passports should be presented to the Ottoman anthorities and permits of sojourn be obtained; the foreign ministers at Constantinople informed the Ottoman Porte that their governments declined to acquiesce in the enforcement of these regulations to the prejudice of their citizens and subjects. ${ }^{3}$ When naturalized citizens of Turkish origin were found possessed of passports issued by Turkish officials, the taking out of those passports was held to have dissolved the obligation of the United States to protect the holders of them. ${ }^{4}$

1 For. Rel. 1890, p. 182.

2 For. Rel. 1894, p. 152; 1897, p. 98, 102.

3 For. Rel. 1888, pt. 2, p. 1563.

- For. Rel. 1894, p. 757, 761; 1900, p. 934. 
Besides the method of certifying to nationality by means Reglsof a passport, there is also the method of registration at a consulate. In the British system registration is required by law under liability to be fined or to lose the right to protection, although failure to register does not exempt a subject from prosecution in a British consular court. ${ }^{1}$ In the American system registration is not made compulsory by statute and possibly cannot be made so by a regulation issued by a minister. ${ }^{2}$ A passport is considered in itself sufficient, and no atditional evidence of citizenship, either by way of registration or by way of certificate in the native language obtained at the consulate or through it, can be held to restrict the effect of a passport. ${ }^{3}$ But where registration is only a local police requirement, a consul may encourage his fellowcountrymen to register, although he cannot oblige them to do so. ${ }^{4}$ Under Article $\mathrm{V}$ of the treaty of March 1\%, 1894, between the United States and China, the United States agrees to furnish annually to China a register or report of American citizens in China and such registers are prepared by the consuls under instructions from the Department of State. 5

The formerly extensive and much abused protégé system in the Levant, under which foreigners of various nationalities and considerable numbers of native subjects could, upon the slight formality of enrolling their names at a consulate, receive its protection, was gradually restricted by consent of the foreign powers until in $1862^{6}$ the Ottoman Porte decreed a regulation strictly limiting the number of protégés to four dragomans and four yassakdjis, cavasses or guards for each consul-general and each consul in the larger cities and to a lesser number for other consular officers.

1 Hall, Foreign Jurisdiction, p. 129.

For. Rel. 1873 , pt. 1, p. 570; supra, p. 55.

For. Rel. 1884, p. 539, 546, 556.

- For. Rel. 1878, p. 864.

5 For. Rel. 1896, p. 90.

- Archives diplomatiques, 1863, pt. II, p. 155; De Testa, Traltés, vol. 1, p 228; Aristarchi, Legislation Ottomane, vol. IV, p. 15 . A full history of the protege system and an explanation of the present restrictions

Restriction of the protége system in the Levant 
Dragomans and cavasses

Some question has arisen as to the extent of the privileges to be accorded to these dragomans and yassakdjis or cavasses. A dragoman named Costa, of the consular agency at Salonica, was sued in 1897 as indorser of a due and unpaid promissory note, and although his official relations had been recognized by issuing the summons to him through the consular agency, the tidjaret or court refused to permit the presence of the two assessors and a second dragoman, allowed by law to American protected persons in such cases, and proceeded to trial and gave judgment in their absence and in the absence of the defendant. The Turkish government affirmed the regularity of this proceeding and stated that according to the ninth article of the regulations of 1863 for foreign consulates, Mr. Costa, being of Ottoman origin, was, in respect to his private affairs, subject to Ottoman jurisdiction exclusicely. The American minister, Mr. J. B. Angell, then called attention to the language of the ninth article which provided, not that Ottoman subjects in the serrice of foreign gorernments, but those in the service of foreign subjects, should be under Ottoman jurisdiction exclusirely. It was proper enough, said the minister, that an Ottoman subject, the clerk of a foreigner, should be treated like any other Ottoman subject in respect to his private affairs, but the dragoman of a consul could not be interrupted in his official duties by vexatious suits in which he might not inroke the presence of a consular representative to see that the interests of the consulate were properly protected. This opinion and the action of the minister were approved by the Department of State. ${ }^{1}$ A different opinion was given in the case of the ejection from possession of a house of the family of a consular carass at Jerusalem in 1888. Although the manner of eviction doubtless warranted

upon it is given in Rey, La protection diplomatique et consulaire dans les échelles du Levant et de Barbarie, Paris, 1899, p. 244-305.

1 For. Rel. 1898, p. 1109. See also the case of Dragoman Avedikian of the consulate at Smyrna, whose business in the interior was interfered with by local authorities and the interference disapproved of by the Porte; For. Rel. 1900, p. 920; one of the features of this case was that an American consular cavass was arrested. 
some redress, it was concluded by the Department of State that real estate held by Ottoman subjects was not taken out of Turkish jurisdiction when such subjects became cavasses in the consulates. ${ }^{1}$ Originally the Turkish subjects engaged to render services in the foreign legations and consulates were exempted from military service by virtue of Article V of the Règlement consulaire, but in 1889, upon expiration of the period named in that article, the Porte announced that these subjects would be liable to military duty, the Mussulmans to actual service and the Christians to the exonerating tax; but the American and British ministers, represeniing the inconvenience the enforcement of this measure would entail, requested that the exemption be continued. ${ }^{2}$ It is the policy of the United States to limit to as few as may be absolutely necessary the persons exempt from the local jurisdiction through their being attached to legations and consulates as assistants, guards or servants and to maintain with firmress the protection of those who are thus engaged; ${ }^{3}$ and acceptance of employment at a consulate with the intention of evading responsibilities under the local law, such as taxation or military service, gives ground for redress only when the action of the local authorities is abrupt.

The Chinese employee of a citizen or subject of a treaty power on the Anglo-American settlement at Shanghai may not be arrested except upon warrant signed by the senior consul, and, if arrested, he may not be tried before a native

1 For. Rel. 1888, pt. 2, p. 1563, 1568, 1602.

2 For. Rel. 1889, p. 724, 728. In 1888 two men, a guard of the Greek consulate at Jerusalem and a British Moslem subject at Jerusalem, were impressed into the Turkish army; For Rel. 1888, pt. 2, p. 1571.

${ }^{3}$ For. Rel. 1871, p. 890,900 . See also MSS. Inst. Turkey and other documents in Wharton, Internat. Law Digest, vol. 1, p. 676-7.

An extreme view of the immunity of legation on the part of a British minister to Japan is stated in For. Rel. 1874, p. 697 .

In the capitulations the consular guards are named janissaries. Protection of the legations at Peking has been afforded not by native employees, but by foreign military and naval forces. There was no provision in the treaties of 1858 for such a guard; its introduction in 1895 was made, however, with the consent of China; For. Rel. 1895, pt. 1, p. 198.

The protocol between the Powers and China of September 7, 1901, Article VII, permits a permanent guard for each legation in the enclosure set apart for the legations; For. Rel. 1901, Append1x, p. 316. 
court outside of the settlement until there has been a preliminary examination in the Chinese or mixed court on the settlement with the result of showing reasonable ground for the accusation; furthermore, unless the crime with which he is charged is of the class punishable with death or banishment, the trial is to take place in the Chinese court on the settlement. ${ }^{1}$ It is believed that a corresponding immunity extends to Chinese employees of foreigners in other ports, ${ }^{2}$ and in some measure to the business associates or compradores of foreign merchants. ${ }^{3}$

Native converts

Jointstock companies

Forelgners employed by native governments
But foreign protection does not in the slightest degree extend to native converts to Christianity as such, and whatever missionaries may do in their behalf can be only in the nature of friendly assistance with permission of the local government. Both the Chinese and the Turkish governments are under treaty obligation not to discriminate against native converts. ${ }^{4}$

The determination, for purposes of jurisdiction, of the nationality of a corporation doing business in an oriental country appears to depend principally upon evidence found in its charter or in the franchise under which it operates in a particular country; ${ }^{5}$ and the nationality of a commercial firm without a charter or a franchise has been held to be the same as the nationality of its principal officer. ${ }^{\circ}$

Foreigners engaged in the imperial customs service of China are privileged from being compelled to give evidence in consular courts; but if a foreigner, while performing his official duties, wounds or kills any one, he is required by the customs regulations to resign his place at once and report to his consul; if convicted, his resignation is considered per-

\footnotetext{
'Sen. Ex. Doc. 36, p. 31 (vol. 1), $53 \mathrm{~d}$ Cong., $3 \mathrm{~d}$ Sess.; infra, D. 171-6.

2 For. Rel. 1900, p. 394.

For. Rel. 1883, p. 156.

Infra, p. 110, 115, 119, 121.

- See Mr. Salem's note to a case tried in the French consular court at Constantinople in 1899. Jour. du drolt internat. prive, 1900, p. 663.

- Scidmore, U. S. Courts in Japan, p. 227.
} 
manent; if acquitted, he may resume his place with full pay from the time of his resignation. ${ }^{1}$

A regulation is reported to have been issued in Turkey in 1899, under which foreigners entering the service of the Turkish government are obliged to furnish a certificate from their consuls that consular jurisdiction shall not extend to cases arising in the exercise of their official services to the government. $^{2}$

It is a rule, believed now to be generally accepted, that for purposes of protection a seaman, duly enrolled as a member of the crew of a merchant ship of a nationality different from his own, is to be regarded of the same nationality as the ship on which he serves. In 1881 in the diplomatic correspondence between the United States and Great Britain concerning the right to exercise jurisdiction over John Ross, a British subject but a seaman on an American ship, for a crime committed on the ship in the harbor of Yokohama, the American authorities took the position that the proper control of the crew of a merchant ship in the waters of a country where extraterritoriality prevals requires that the members of the crew, foreigners as well as native born, be subject to the same national jurisdiction as the ship. It does not appear that the British government declined to acquiesce in this proposition. When the Ross case came before the Supreme Court in 1890, the view expressed in the correspondence with Great Britain was held by the court to determine the status of the prisoner. Therefore the rule in its full breadth, as applicable in American consular courts where extraterritoriality exists, is that all persons duly enrolled as members of the crew of an American ship are subject to American jurisdiction alone. ${ }^{3}$

For. Rel. 1881, p. 257.

2 Jour. du droit internat. prive, 1899, p. 223; Moniteur oriental, November 28, 1898.

${ }^{3}$ Consular Regulations, Par. 629. Previously, the full jurisdiction extended only to seamen on naval vessels; McCondrill's case, For. Rel. 1885 , p. 556, and instruction of November 2, 1875, quoted in Wharton, Internat. Law Digest, vol. 1, p. 808. Hall, Foreign Jurisdiction, p. 142,

Foreigners employed as seamen on AmerIcan
shlps 
Friendly offices toward forelgners are non-

juris-

dictlonal

American consuls have at times been instructed to exercise friendly offices in behalf of persons of other nationality than their own. This was the case during the war of 1894-5 between China and Japan, when American consuls in both countries exercised friendly offices toward Chinese and Japanese, but without assuming any jurisdiction over them. ${ }^{1}$ Instances of friendly offices in time of peace frequently occur in the Levant. The British and American consuls in the interior of Turkey have thus coöperated in the protection of missionaries. ${ }^{2}$ At the request of Switzerland and with the consent of their own governments, consuls of different nationalities have even exercised civil and

holds that protective, but not punitive, jurisdiction can be exercised by British consuls over foreign seamen on British ships. The ground taken by Hall resembles that which had been previously elaborated in the able brief of Professor G. W. Kirchwey, counsel for petitioner in In re Ross, 140 U. S. 453.

Three Filipinos, seamen on board the American transport Liscum, were tried in 1902 in the consular court at Shanghai for the murder of a Chinaman; North China Herald, vol. lxix, p. 1248, 1304, December $10,17,1902$.

The minor offenses of naval seamen on shore-leave are under concurrent jurisdiction of the consular and naval authorities: For. Rel. 1888, pt. 2, p. 1665.

A foreigner, the master of an American owned unregistered merchant vessel, sailing under an American flag, and whose name was borne upon the ship's articles, was held to be under the jurisdiction of the American consular court at Kanagawa in 1886 for a crime committed in Japan; U. S. $\vartheta$. Fullert; Scidmore, U. S. Courts in Japan, p. 229.

Chinamen employed as seamen on American ships have the status of American seamen, even in Chinese waters; For. Rel. 1892, p. 343. A Japanese seaman on an American naval vessel was held subject to American consular jurisdiction in 1882 for a crime committed in Japan; In re Ikada Tomekichi, Scidmore, U. S. Courts in Japan, p. 229.

The jurisdiction does not extend to the families of seamen; For. Rel. 1888, pt. 2, p. $1075,1079$.

Conviction in a consular court of having committed a felony operates at once to withdraw American privileges from an alien member of an American crew; For. Rel. 1888, pt. 2, p. 1665. Desertion has the same effect; For. Rel. 1885, p. 656.

It was held by Mr. Bingham that an Austrian, a seaman deserting from the American naval service In Japan, was not entitled to consular relief; For. Rel. 1885, p. 556. But in 1856 a British subject, a deserter not then legally discharged from service on an American shlp, was tried in the American consular court at Canton; Sen. Ex. Doc. 22, p. 820 (vol. 9), 35th Cong., 2d Sess.

1 Infra, p. 174-5.

'For. Rel. 1882, 495, 501 
criminal jurisdiction over citizens of Switzerland in Turkey, Egypt and the Barbary States. ${ }^{1}$

But such an extension of extraterritorial jurisdiction has not been consented to by China. The subjects of non-treaty powers in China are not privileged to have any other jurisdiction than that of the Chinese courts. The American government disapproved the action of a consul at Canton in 1872 when he assumed to try a citizen of New Granada, notwithstanding the accused had assented to be tried. ${ }^{2}$ In 1902 upon request of the Republic of Cuba and with the consent of various foreign governments, including China, the United States government instructed its consuls to exercise good offices in behalf of citizens of Cuba; this is announced as a temporary arrangement intended to continue until Cuban consuls shall have been appointed. ${ }^{3}$ The scope of the authority conferred is briefly defined as not empowering the consuls "to act as agents of Cuba . . . but to use good offices, as intermediaries," reporting only to the Department of State. ${ }^{4}$ Nothing whatever is said respecting extraterritoriality; upon principle, however, this privilege would inhere in Cuban citizens in Turkey, though not in China, and there appears to be nothing to prohibit the issuance of instructions in special cases for the exercise of jurisdiction over a Cuban eitizen by an American consul in Turkey.

The privileges of extraterritoriality may be so abused as to justify the expulsion of the offender from the country. ${ }^{5}$ This measure of expulsion or deportation was provided for in the treaty of July 29, 1858, between the United States

Results of abus. ing extraterritorial privileges

\footnotetext{
${ }^{1}$ In 1892 the French consul at Constantinople exercised jurisdiction in the contest of the will of a Swiss citizen, applying the principles of Swiss law to the case; Jour. du droit internat. privé, 1896, p. 671. The German consul at Constantinople tried a Swiss citizen for robbery, and the expense of the trial was charged to the canton of Lucerne; Jour, du droit internat. privé, 1898 , p. 223.

${ }^{2}$ For. Rel. 1873, pt. 2, p. 139.

3 For. Rel. 1902, p. 6, 234. The matter does not appear from the public documents yet to have been taken up by the government of Turkey; For. Rel. 1902, p. 1041.

'For. Rel. 1902, p. 329.

- Infra, p. 105-7. As to restrictions upon Mormons, see For. Rel. 1898, p. 1112 .
} 
and Japan. There have been cases of exclusion from Turkey, and the right of Egypt to expel has been admitted. ${ }^{1}$

Effect of prolonged residence abroad

Prolonged residence under extraterritorial jurisdiction does not, as it would in a European country, imply renunciation of citizenship except for naturalized citizens who have returned to the country of their origin. ${ }^{2}$ There are many such naturalized citizens now residing in Turkey, and the status at least of those who have not retained membership in an American community in Turkey, that is, of those who have completely merged themselves in the native population, is doubtful. How long a period it is that causes the right to American citizenship to become extinct is not clear; the usual test is want of intention again to take up residence in the United States. But citizens by birth, provided they retain their allegiance, do not forfeit their citizenship by prolonged residence under extraterritorial jurisdiction. ${ }^{3}$ On this ground passports have been issued to missionaries in China without requiring them to prove retention of domicil in the United States or intention to return to the United States. ${ }^{4}$ The status of the first generation of children of citizens born in Turkey or China is, upon a generally accepted principle, the same as that of the father, no matter what may have been the original nationality of the mother; but Section 1993 of the Revised Statutes provides that "the rights of citizenship shall not descend to children whose fathers never resided in the United States," and this provision would operate in many cases to deny the rights of citizenship to children of the second generation under extraterritorial jurisdiction if exception were not made in favor of those who remain niembers of distinctive American communities. This exception was declared available to such persons by Secretary of State Bayard in an instruction to

'Dipl. Corr. 1866, pt. 2, p. 269; infra, p. 106-7.

${ }^{2}$ Case of Hajie Seyyah, Persia; For. Rel. 1893, p. 487, 496, 505, 506, 508,

s Case of Hatchdoorian; For. Rel. 1887, p. 1126, 1131.

That legitimacy of occupation is not a criterion was held in the cases of two women llving at Port Arthur; For. Rel. 1899, p. 185.

- For. Rel. 1892, p. 124; 1900, p. 390. 
the consul at Smyrna, replying to a memorial prepared by Messrs. Blackler, Langdon and Offley, who resided in Smyrna and desired to have their children registered at the consulate as American citizens. ${ }^{1}$ Undoubtedly the same exception would extend to children of the second and succeeding generations in China and other countries where extraterritorality prevails; and it is probable that membership in a community of citizens would be regarded as meaning simply continued association with other Americans, either by residing in a foreign settlement as at Shanghai or, if living in the interior, by being identified with distinctive American interests as at a missionary station or a business agency.

It is impossible for an American citizen to exempt himself from his national jurisdiction in Turkey or China exExpatriation cept by renouncing his nationality." The only partial exceptions are in respect to real estate in Turkey and to residence at a distance of nine or more hours travel from a consulate in Turkey. A citizen is at liberty to expatriate himself and only in that way can he forego the protection and jurisdiction of the United States.

\section{II-THE RULE OF DOMICIL; MARRIAGE; INHERITANCE}

What law is applicable in particular cases in consular the rule courts often depends upon the domicil of the parties. For example, questions pertaining to the validity of a marriage or the settlement of an estate may not be disposed of without first determining the domicil of the parties to the marriage at the time they entered into that relation or the domicil of the deceased at the time of his death. In general all matters dependent upon personal status involve the determination of domicil.

1 For. Rel, 1887, p. 1120.

- Case of Dr. Dondjian; For. Rel. 1891, p. 751 . Inquiry by the Japanesø Government; For. Rel. 1877, p. 354 ; also 1874, p. 643, 645. 
Oriental domicll not ac. quilred

Domicil of orlgin retained

The essential features of domicil are, first, residence in a particular place, and, secondly, intention to remain permanently in that place. Many American citizens residing in oriental countries have no intention of returning to the United States, and it might naturally be asked whether they had acquired an oriental domicil. But the law of domicil is inapplicable to the case. It is of the very essence of treaties of extraterritoriality, and of the laws to give them effect, to extend to the alien the benefits and to subject hin to the obligations of the law of his own country. ${ }^{1}$ An American citizen may, for instance, reside in shanghai all his life and yet be free from the operation of the law of China. In short, though residing permanently in Shanghai, he retains not only his American nationality but also his American domicil, which is conceived to continue in the state or territory in which he had his home. Thus the distribution of property of a citizen of California dying intestate in China would presumably be controlled by the law of California in all respects in which the statutes and regulations had not otherwise provided, although the question does not appear to have been adjudicated by the courts in the United States.

Under British foreign jurisdiction a rule was at one time in force that a person in the service of the British East India Company acquired an 'Anglo-Indian' domicil, which for testamentary purposes was equivalent to English domicil. But the inconvenience of admitting such a theory caused it in time to be disregarded, and it has been held in recent years in a series of cases that a British subject cannot acquire a domicil in Turkey or in China, and that he retains his British domicil. ${ }^{2}$

${ }^{1}$ Dicey, Conflict of Laws, p. 29, 723-5.

2 Maltass $\because$. Maltass, 1 Rob. Eccl. Rep. 67; Re Bethell, L. R. 38 C. D. 220; Re Tootal's Trusts, L. R. 23 C. D. 532; Abd-ul-Messih $\%$ Farra, L. R. 13 A. C. 431. See also Piggott, Exterritoriality, p. 139-55; Hall, Foreign Jurisdiction, p. 180-6. 
The Revised Statutes, Section 4082, provide that:

Marriages in presence of any consular officer of the United States in a foreign country, between persons who would be authorized to marry if residing in the District of Columbia, shall be valid to all intents and purposes, and shall have the same effect as if solemnized within the United States. And such consular officers shall, in all cases, give to the parties married before them a certificate of such marriage, and shall send an. other certificate thereof to the Department of State, there to be kept; such certificates shall specify the names of the parties, their ages, places of birth and residence.

It is thus declared that the capacity of parties to enter into the contract of marriage is to be determined according License to to the law prevailing in the District of Columbia. But it is not permitted to diplonatic or consular officers, without special authority from the Department of State, to issue any instrument in the nature of a license to marry or a certificate of freedom from matrimonial disabilities, or to make any official statement as to the law of the United States or any part thereof relating to the solemnization of marriage. ${ }^{1}$

The effect of the presence of a consular officer at a marriage ceremony is merely to enable and oblige him to certify to the marriage as an official witness. His presence in nowise gives 'legality' to the marriage, and his duties are confined to the certification of it.

The statutes confer no authority upon diplomatic officers either officially to witness or to certify to marriages. As there has been no American consulate at Peking, requests have occasionally been made to the minister to attend marriage ceremonies for the purpose of giving them 'legality'; one of the earlier ministers is said to have complied with such requests, but in 1890 the Secretary of State approved the action of a minister in declining to do so."

Marriages solemnized without the presence of a consular officer are not invalidated by the statute quoted above, al-

' For. Rel. 1890, p. 197, 209. 
though as a measure of precaution the observance of the statutory method is considered desirable. The general rule that the mode of solemnization is to be that prescribed by the law of the place of solemnization is, of course, not applicable in countries where, as in Turkey and China, Americans are exempt from the local law in their personal relations. In 1878, when the United States had a treaty of extraterritoriality with Persia but was unrepresented by either a diplomatic or a consular officer in that country, an opinion was requested of the American minister at Constantinople, Horace Maynard, how a narriage between Americans in Persia might be solemnized so as to make it legally valid. It was Mr. Maynard's opinion that in view of the circumstances, a ceremony in which the parties declared their mutual consent and to which a clergyman or local magistrate gave certification, which should be recorded in the consulate at Constantinople, would be held to be valid..

Intermarriage with foreignern

The proposed intermarriage of a British subject with an American woman, both the parties residing in China, was the occasion of a correspondence in 1888-9 as to the validity and certification of mixed marriages in that country. A plan was devised to have two ceremonies, the first according to American law and the second according to British law; and the American minister, Mr. Charles Denby, agreed to communicate to his British colleague his 'recognition' of the validity of the marriage before the American consular officer. The Secretary of State, Mr. Bayard, expressed the opinion that, if Mr. Denby "should recognize as valid consensual marriages in China, such marriages being exclusive sexual unions for life," he would be "acting in conformity with the great body of judicial authority in the United States." Mr. Bayard separated the question of the form of the ceremony from that of the capacity to marry, stating that the prevailing view in regard to the latter question was that the law of domicil controlled and that every precaution shonld be taken by an American to prevent impeachment of

${ }^{1}$ For. Rel. 1879, p. 977-8; also supra, p. 79, note 7 . 
the marriage before the courts of the country in which the other party to the marriage would be held to have domicil.

In a divorce case before the American consular court at Divorco Shanghai in 1902, it was argued by counsel, and the argument appears to have been accepted by the court, that the law under which the rights of the parties should be determined, their marriage having taken place at Maracaibo, Venezuela, was the law of the District of Columbia. ${ }^{1}$ The question of domicil in some state or territory of the United States seems not to have been brought up.

One of the particulars in which the Secretary of State, in 1870 , thought that the regulations for consular courts in Japan should be amended, related to divorce; but his objections were not sustained by Congress, which tacitly approved the regulations in their entirety. ${ }^{2}$ The principal difference between the regulations for Japan and the regulations for Turkey and China, in respect to jurisdiction of divorce, was that the regulations for Japan declared the grounds upon which divorce might be granted, while the other regulations were confined to matters of procedure. ${ }^{3}$

The treaties of the United States with Turkey and China do not contain express stipulations regarding the care of property of deceased American citizens, but the principle of extraterritoriality, applicable in both countries, that in matters concerning the personal relations and the personal property of foreigners of the same nationality, jurisdiction belongs exclusively to their national authorities, covers the larger number of cases. When the heirs or successors are of different nationalities, not including natives, jurisdiction of such matters is, by another principle of extraterritorality, left to be determined under whatever arrangement the respective foreign governments have made. If there are native claimants of the personal property of a deceased

\footnotetext{
1 North China Herald, vol. 1xlx, p. 1138, 1194, November 26, December 3, 1902.

${ }^{2}$ Mr. Fish to Mr. DeLong, December 29, 1870, Wharton, Internat. Law Digest, vol. 1, p. 807.

Sen. Misc. Doc. 89 , p. 72, 106, 169 (vol. 1), 47th Cong., 1st Sess.
} 
Succession to real property in Turkey

American, the jurisdiction of Turkcy or China, as the case may be, is still excluded, although, under the provisions of the treaties that Turkey retains jurisdiction of cases involving Turkish subjects, the Turkish gorernment contends that the claims of Turkish creditors against the estate of a foreigner in 'Turkey are to be brought before Turkish conles. ${ }^{1}$

As to the inheritance of real property in Turkey the opinion has been expressed by an eminent authority that under the law of 1867 , granting to foreigners the right to acquire such property and declaring that in the enjoyment of this right they are assimilated to Ottoman subjects and are justiciable before Ottoman tribunals, the Ottoman tribunals have exclusive jurisdiction of the subject. ${ }^{2}$ It is said that in practice the Ottoman authorities require a consular certificate showing what persons are lawful heirs of the deceased, but this formality is not understood to prevent the Ottoman authorities from disposing of the property according to Ottoman law. The fourth article of the law of $186 \%$ is susceptible of being interpreted so as to limit the Ottoman jurisdiction to intestate succession, but the more explicit language of the second article would no doubt preclude such a limitation.

The first article of the law of 1867 provides that the privileges granted therein are not to be extended to "subjects of Ottoman birth who have changed their nationality," and that such subjects "shall be governed in this matter by a special law." The Turkish government has held that the special law here referred to is not a law subsequently to be enacted but is the law provided in Article III of the real estate code of 1858, which declares that land once owned by a Turkish subject who has abandoned his nationality does not descend to his children. ${ }^{3}$ This provision is in accord-

1 Salem, Du droit des étrangers de transmettre par succession en Turquie, Jour. du droit internat. prive, 1898, p. 665, 671, in which reference is made to correspondence between Turkey and the Netherlands on this point in 1879; also ibid., p. 1030 .

Salem, De la succession Immobilière des étrangers en Turquie, Jour. du droit internat. prive, 1899 , p. 470, 472; also Ibid., p. 47.

- For. Rel. 1897, p. 588; see also 1883 , p. $809,815,821,833$. 
ance with the Mohammedan sacred law, which prohibits inheritance in Turkey by a person of a different nationality, that is of different religion, from that of the deceased. ${ }^{2}$ It is believed, however, that the Turkish government does not insist upon the enforcement of the law of 1858 in this particular.

The acquisition of real property in China does not place a foreigner under Chinese jurisdiction with respect to such property. It is therefore impossible for China to exereise jurisdiction with respect to succession to the real property left by a deceased foreigner. It was held in Macdonald $v$. Anderson in the British consular court at Tientsin, in 1904, that the principle of lex loci is to prevail in respect to real property rights of foreigners in China. ${ }^{2}$

It is not unlikely that under the American foreign jurisdiction the same prinicple would be followed, and only to this extent would the rights of heirs and successors be affected by the law of China.

The United States court for China exercises supervisory control over consuls in the care of estates of decedents in China. Within sixty days alter the death of a citizen in China, the consul is to file with the clerk of the court a sworn inventory of the effects and a schedule under oath of the debts. A consul is to pay no claims or make sale of any asset withont written approval of the judge. The judge may require from a consul at any time reports of what the consul has or is doing with respect to the estate. He may also require a special bond, and for failure as to the bond or in care of the estate, the court may appoint some other person to take charge under bond. The clerk is to keep a record of all proceedings with respect to the estate under this statute. ${ }^{3}$

\footnotetext{
'Salem, Du droit des étrangers de recueillir par succession en Turquie, Jour. du droit internat. prive, 1899, p. 961, 964.

' North China Herald, February 5, 1904, p. 247. A portion of the judgment pronounced by Mr. Justice F. S. A. Bourne in this case is printed infra, Appendix VIII.

See also, to same effect, Secretary of State for Foreign Affairs $z$. Charlesworth Pilling Company and others, appealed from a Britlsh court in Zanzibar. L. T. R., vol. 84, N. S., p. 212.

${ }^{3}$ Act of June 30, 1906, Sec. 2; see Appendix III-2.
}

Successlon to real property in China 


\section{III-PERSONS ACCUSED OF CRIME}

Petty ofrenues

Acts named In the treaties as indict2 ble

Effect of local police regulations.
By far the greater number of offenses dealt with in the consular courts are such lesser disturbances of the peace as fall within the jurisdiction of municipal police courts in the western countries. The consular courts located at the principal centers of trade have marshals and prisons for the custody of criminal offenders, ${ }^{1}$ and in other places the services of native police and the use of local prisons may be engaged as occasion requires. The procedure in criminal cases, while intended sufficiently to protect the rights of the accused, is nevertheless simple and summary. ${ }^{2}$

In general no act is indictable as a crime under the foreign jurisdiction which would not be indictable in the United States. But there is an obvious exception to this rule in that the treaties with China, Korea and Siam stipulate with some particularity what customs, shipping, and import and export trade regulations shall be observed and provide that infractions of these regulations may be penalized by the oriental government itself to the extent of confiscating the prohibited goods or the offending ship and its cargo. ${ }^{3}$ The same class of rights is a subject of stipulation in the treaty between Turkey and Germany of August 26, 1890, under which, by virtue of most-favored-nation clauses, the trade with other countries is also regulated.

It has been the policy of the United States to require of its citizens to observe the regulations prescribed by the oriental governments for the security, good order, health and general welfare of local communities, and it is believed

1 The annual Diplomatic and Consular Service Appropriation Act of June 16, 1906, appropriated for interpreters and guards in Turkey and Zanzibar, $\$ 12,000$; for marshals of consular courts in China, Korea and Turkey, $\$ 11,000$; for the keeplng and feeding of prisoners in China, Korea, Slam and Turkey, $\$ 9,000$; and for other similar specified purposes, $\$ 4,150$; total, $\$ 36,150$. Public-No. 236 .

"The Earl of Aberdeen, in transmitting copies of the Forelgn Jurisdiction Act of 1843 to Sir Stratford Canning at Constantinople, Inclosed an excellent memorandum for the use of consuls, explaining the summary nature of their criminal jurisdiction; Brit. and For. State Papers, vol. 32 , p. 856 .

${ }^{3}$ As to the effects of the customs regulations of Japan see For. Rel. 1898 , p. 432 . 
that such regulations have been enforced in consular courts just as if they were regulations published by the American ministers to those countries. Other foreign governments have taken the ground that their nationals were amenable only to the laws of their own countries, and in 1879 some of these governments were indisposed to enforce quarantine regulations prescribed by Japan for preventing the bringing in of cholera from other countries in the Far East. But the United States coöperated with Japan by securing strict observance of the quarantine on the part of American ships. ${ }^{1}$

A form of offense that occasionally occurred in Japan was that of trespassing beyond the limits of treaty-ports. When the offender had been conducted back to the port and complaint had been made to the consul, the matter ordinarily ended without trial. ${ }^{2}$ Although there still exist some treaty restrictions upon travel in the interior of China and Korea, special permits for such travel are often issued.

Other offenses named in the treaties with China and Korea are: concealment of native offenders, aiding in or procuring the forcible emigration of Chinese coolies, insulting, troubling or wounding the person or injuring the property of the Chinese or Koreans, or committing any other improper act in China or Korea, or making improper use of the American flag.

1 For. Rel. 1879 , p. 604, 608, 647, 657, 665, 670; 1880, p. 679. Sheppard, Extraterritoriality, Tokio, 1879, a treatise which had special reference to the obligations of foreigners under the municipal law of Japan, contains, at p. 48, the following language: Japan "maintains that the judicial authority conferred upon consuls by virtue of the extraterritorial provisions of existing treaties, in no way denies to her the exercise of her original inherent sovereign power to prohlbit by general law the commission of any crime by any and all persons whomsoever, within her territorial limits, not inconsistent with the treaty right of trial and punishment. As to penalties and punishments prescribed by Japanese laws, the consular courts may justly hold that they are not applicable to thelr own nationals; but as to the prohibitions therein contained, they are obligatory upon all.

The treaty provisions relate exclusively to the mode of trial and measure of punishment: to the remedy."

The United States had affirmed the same principle in regard to the Japanese hunting regulations; For. ReI. 1871, p. 586; 1874, p. 637, 645, 653; 1875 , pt. 2 , p. $773,779,819 ; 1876$, p. 350,366 .

${ }^{2}$ For. Rel. 1874 , p. $660,662,668 ; 1875$, pt. 2, p. 821 ; see also, as to China, Dipl. Corr. 1868, pt. 1, p. 547. 
Political orfenses

The Statutes themselves, it has been shown, ${ }^{1}$ specify the exceptional procedure that shall take place in a trial for either of the two crimes punishable with death, namely, insurrection or rebellion against the local government, and murder; but they do not indicate what degree of political offense shall be held to constitute insurrection or rebellion. It has been suggested that a definition of this crime and of what is necessary for conviction of it, may be inferred from the definition of treason, and from the provision regarding trials for treason, contained in Article IV, Section 3, of the Constitution of the United States, yet it cannot be said that the rights of an accused person under this section must of necessity be observed in an extraterritorial court any more than the right of trial by jury must be observed by such a court.

In each of the few instances when charges of having committed a political offense have been brought against American citizens, the matter has not even reached the stage of a formal trial. The government of China engaged the services of a certain General Burgevine, an American, to assist in suppressing the Taiping rebellion; Burgevine shifted his allegiance from one party to another until, upon complaint of the Chinese government, the American authorities informed him that he would no longer be regarded as having a right to American protection in China. ${ }^{2}$ Since 1890 a number of naturalized citizens of Armenian birth, resuming their residence in Turkey, have been accused of being agents of revolutionary societies, but no open act against the Turkish government has been proved, and the United States has contented itself with declaring that it would regard their continned residence in Turkey as equiralent to a renunciation of their naturalization. ${ }^{3}$ The right of Turkey, upon notice to the consul and with his coöperation, to refuse to admit into its territory or to expel from it former Turkish

'Supra, p. 47-8.

'Dipl. Corr. $1 \$ 63$. pt. 2, p. $\$ 64 ; 1865$, pt. 2, p. 452 ; 1866, pt. 1, p. 462.

- For. Rel. 1ऽ94, D. $753 ; 1895$, pt. 2, p. 1295, 1300, 1304. 
subjects reasonably suspected of hostile intent toward the goverument, cannot be doubted.

During the war between France and China in 1885, China Noncomplained that Americans were being employed as pilots neutral on French naval vessels. The answer of the United States was that its statutes had not forbidden citizens to make private contracts with foreign belligerents at their own risk and that such contracts were not cognizable in consular courts. ${ }^{1}$ Yet it is specified in Section 4090 of the Revised Statutes that "every such minister" [that is, minister to a country where extraterritoriality prevails] "may issue all manner of writs, to prevent the citizens of the United States from enlisting in the military or naval service of either of the said countries [that is, where extraterritoriality prevails], to make war upon any foreign power with whom the United States are at peace, or in the service of one portion of the people against any other portion of the same people; and he may carry out this power by a resort to such force belonging to the United States as may at the time be within his reach." Such writs were issued by a minister to China, R. M. Mc Lane, December 5, 1854, and were no doubt regarded as of equal standing with the ordinary regulations enforceable in consular courts. ${ }^{2}$ It may be noted that the statute does not provide that military service for a foreign power at war with a country where extraterritoriality prevails may be prevented, but only provides for preventing such service in behalf of such an oriental country against a power friendly to the United States or serving in a civil war in an oriental country. ${ }^{3}$

In the same war of 1885 between France and China in- Trading structions were issued covering the hypothetical question in conwhether vessels of American registry could be lawfully sold in China to the Chinese and declaring that, where the ulti-

1 For. Rel. 1885, p. 156, 160.

${ }^{2}$ Ho. Ex. Doc. 32, 34th Cong., 1st Sess. Twenty years later this was held to be still in effect; For. Rel. 1874, p. 256, 300.

${ }^{3}$ Consuls may not publish anything in the nature of regulations to prevent non-neutral acts; For. Rel. 1874, p. 332. 
mate object of the transaction was hostile and consular authorization was necessary to validate the transfer, the consul would not be justified in taking any part in it; but that he would not, on the other hand, be justified in taking positive preventive measures; and that the transfer, if made, would be at the owner's risk and peril. ${ }^{1}$ The American minister at Peking gave instructions also that to enter or clear a ship known to have a cargo of contraband would be a questionable proceeding. ${ }^{2}$

Pro-

cedure in the trial nal offenders

The Buckley case, Shangha1, 1864

While no trial under the foreign jurisdiction for the crime of insurrection or rebellion against an oriental governnent has occurred, there have been trials for murder in China, Japan and Egypt, and the rights of the accused in such trials have been well determined. In the trial of John Buckley at Shanghai in $1864,{ }^{3}$ objections were made by the prisoner's counsel that there had been no indictment presented by a grand jury, that the accused had not been tried by a jury, and that the four associates sitting with the consular judge had been allowed to separate and to go about their ordinary business after the commencement of the trial; and it was further represented that since the decision of the consular court in a capital case must be referred to the minister at Peking for his sanction, it would seem to follow that the minister would have power to set aside a judgment manifestly erroneous; and the petitioner prayed that if the minister declined to reverse the decision of the consular court in the case, then the execution be stayed and the case be submitted to the President. The minister at Peking approved the decision of the consular court, and a strong effort was made, but unsuccessfully, to bring the matter before the President. The objection to the separation of the associates on the trial was held by Consul-General Seward not to be well grounded, because associates, he said, were merely advisers and not judges, and the Statutes contained no pro-

1 For. Rel. 1885 , p. 170.

- For. Rel. 1885, p. 168.

- Dipl. Corr. 1864-5, pt. 3, p. 400, 440, 474, 478. A statement of the case is also given in the case of In re Stupp, 11 Blatchford, 124, 148. 
hibition against the separation of associates. The principal objection, that proceeding without a jury on the trial was unconstitutional, was much more fully discussed and the objection overruled in the case of In re Ross before the Supreme Court in $1890 .^{1}$

When S. P. Mirzan was tried for murder at Alexandria, The Egypt, ${ }^{2}$ the question arose whether the list of names of citizens, who might be summoned as associates on the trial, could be supplemented immediately before the selection of Mirzan case, Alex1879 associates for a particular case was to be made; the minister at Constantinople held that the list could be so supplemented, and that the circumstance that the list was made three years earlier and contained only nine names, justified its being done. The Mirzan trial took place before Vice Consul-General Comanos in the absence of the consul-general. Mr. Comanos desired full instructions as to the procedure proper to be followed, and in the instructions sent to him by the Secretary of State, W. M. Evarts, he was directed to allow Mirzan to have counsel for his defense and, if necessary, compulsory process to secure the attendance of witnesses; in case of conviction, a copy of the record of the proceedings, including the evidence, additional to the copy required to be sent to the minister, was to be sent to the Department of State, and execution was to be stayed until the record had been examined in the Department and instructions thereupon received.

The arrest of a foreigner, a criminal offender in an ori- Arrests ental country, is made either by the consular marshal or by officers of the local government, but, if by the latter, the prisoner may not be detained in a prison under charge of the local government and must immediately be handed over to his consul. Upon request of the consul, officers of the local government are required to render assistance at any stage of the proceedings of the court or in the execution of the judgment. Asylum cannot be given to a native offender in the dwelling of an American, in his place of business, in an

${ }^{1}$ Supra, p. 66.

2 For. Rel. 1879, p. 987, 1010, 1012. 
Transfer of offenders in China

Consuls have no power to extradite

Amerlcan extradition treaties

with Ja.

pan and

Turkey
American ship or in an American consulate; but with exception, in Turkey, of buildings occupied by Americans and situated at a distance of nine or more hours from a consulate, none of these places may be entered by officers of the local government for search or apprehension of criminal offenders without the assent of the consul and in the presence, if he deems necessary, of a consular officer; ${ }^{1}$ and no doubt natives are subject, in practice, to similar restrictions against giving refuge to American offenders.

In 1897 a question arose in China whether an American charged with the commission of crime in one consular district and fleeing to another might be arrested in the second district and returned for trial in the consular court from whose jurisdiction he had fled. To remove any doubt in the matter a regulation declaring the legality and prescribing the method for such a transfer was published. ${ }^{2}$

It is well established that American ministers and consuls have no anthority under extradition treaties to deliver up fugitives from justice. ${ }^{3}$ Where such a treaty refers to the commission of a crime within the 'jurisdiction' of either contracting party, the word jurisdiction is held not to include the extraterritorial jurisdiction, but only the territorial. ${ }^{4}$ Consequently, a British subject charged with committing embezzlement in Japan and fleeing to California was not extradited from this country, because the treaty with Great Britain was regarded as covering only offenses committed in the territory of either the United States or Great Britain. ${ }^{5}$

The United States has no treaty of extradition with China. Its extradition treaty with Japan was made in 1886, and with Turkey in 18\%4. In making these treaties the policy of the United States diverged from that of Great

1 Infra, p. 131-3.

${ }^{2}$ Sen. Ex. Doc. 32, p. 1-3, 55th Cong., 2d Sess.; see also For. Rel. 1897, p. S0. This regulation is printed infra, Appendix IV-3. Cf, a Chinese proclamation on rendition, For. Rel. 1888, pt. 1, p. 258.

a For. Rel. 1892, p. 69, 74; For. Rel. 1897, p. 80; 20 Opin. Atty-Gen. 391; Moore on Extradition, Sec. 464, China; Sec. 515, Turkey.

- Moore on Extradition, Sec. 89, 109.

- For. Rel. 1875, pt. 2, p. $817,821$. 
Britain, as we shall see, and admitted no right on its own part in virtue of its extraterritorial jurisdiction to apprehend fugitive offenders in Japan or Turkey and remove them to its own territory for trial. It is said that the Turkish government denies that the extradition treaty of $18 \% 4$ is in force. ${ }^{1}$

The arrangements for extradition between Great Britain for its colony of Hongkong, and China, with respect especially to the region of Canton, are rery explicit. Great Britain has extradition treaties with other oriental states, but not with Turkey; for purposes of extradition from Turkish dominions portions of the Fugitive Offenders Act of 1881 are adapted to those dominions as if they were British possessions. $^{2}$

Besides the penalties of fine, imprisonment, and death, which, according to the statutes, may be imposed upon Americans convicted of crime in consular courts, there is what may be regarded as a form of penalty, namely, deportation or exclusion from the oriental country, but no person has been or can be sentenced to deportation or exclusion in an American consular court, and these forms of punishment appear to have been inflicted in only two countries, in Japan, under the express provisions of the treaty of 1858, and in Turkey, by the native authorities with the acquiescence of the American government.

The treaty of 1858 with Japan provided that Americans convicted of felony or twice convicted of misdemeanor should lose their right of permanent residence in Japan and that the Japanese authorities might require them to leave the country and not to return. The deportation of such an offender devolved exclusively upon the Japanese authorities. No consular court could sentence him to deportation or take forcible measures to expel him, although, so long as he remained in Japanese territory, he continued to be subject to the jurisdiction of the United States consular courts. The only right he forfeited was that of staying within or re-

1 Moore on Extradition, vol. 1, p. 102, footnote 1, and p. 815.

${ }^{2}$ Hertslet, Commercial Treaties, vol, xv, p. 432. 
ëntering Japanese territory. Any act of violence he might commit while the Japanese authorities were enforcing his deportation would be under the sole jurisdiction of his consul. Of course no person could be deported whose sentence in a consular court had not been served. ${ }^{1}$

Expulsion or excluslon

from Turkey

There is obviously much difference between the right of deportation as it was exercised by Japan under the treaty of 1858 and the right of exclusion or expulsion exercised by Turkey and admitted by the United States with certain important restrictions. The government of Turkey has claimed the right to exclude or expel undesirable or dangerous classes of aliens and has regarded as undesirable or dangerous certain naturalized United States citizens formerly Turkish subjects. In fact Turkey has claimed the right to refuse the privileges of residence to all of its former subjects naturalized abroad without permission since 1869 . This general claim is apparently in direct opposition to the privileges of residence, trade and travel conceded in the capitulations and treaties to foreigners of various nationalities without distinction as to their former allegiance to Turkey. In practice, however, the European governments either have declined to naturalize Turkish subjects except when they have shown permits to be so naturalized or have refused to protect such naturalized subjects returning to Turkey. The United States, while affirming the inherent right of individuals to expatriate themselves, admitted that there was some foundation for the complaint of Turkey that Armenians had been found obtaining American citizenship in bad faith with the intention of returning to Turkey to cause sedition, and therefore, when the Turkish government announced its policy of expelling such persons naturalized abroad since 1869, the United States, having no naturalization treaty with Turkey and recognizing the justice of this policy, instructed its minister at Constantinople to secure only their protection from unnecessary harshness of treat-

${ }^{1}$ For. Rel. $187 \varepsilon$, p. $518 ; 1879$, p. 697; 1894, p. 376. 
ment. ${ }^{1}$ But the United States aid not eoncede that such persons might be arrested or detained for any other purpose than that of immediate exclusion or expulsion. ${ }^{2}$

On the other hand native eitizens of the United States and naturalized eitizens not of Turkish origin may not be expelled by the Turkish government for the purpose of prechuding the United States from exercising its treaty rights of jurisdiction over erimes which they may be charged with committing on Turkish soil. ${ }^{3}$

Under British foreign jurisdiction there are large powers of deportation of British subjects from oriental countries to British possessions and deportation is admissible either for administrative reasons, that is, because the presence of the individual is injurious to the peace and welfare of the community, or with a view to his trial or his punishment. No such powers exist in the American system.

The penalties imposed by a consular court may be executed and the term of imprisonment served anywhere within the territory of the country in which the crime and the conviction for it oceurred, according to the discretion of the minister.* Thus a criminal oifender convicted in any consular district of China could be made to serve his penalty anywhere else in China, and a prisoner conld be sent from Egypt to Smyrua for punishment. Under the British system of foreign jurisdiction deportation for the purpose of punishment is freely allowed.

The only provision for the exercise of pardon toward persons convicted in Ameriean eonsular courts appears to be that the minister may postpone execution of a death penalty and submit the case to the President for pardon. ${ }^{5}$ In the cases of Dinkelle, Mirzan and Ross, the penalty of death was commuted to imprisonment for life, the condition of the

Deporunder the British system

Place of serving penalty

\footnotetext{
${ }^{1}$ President Cleveland's annual message, December 4, 1893; For. Rel. 1893, p. $\mathbf{x}$.

2 For. Rel. 1894, p. 755.

- For. Rel. 1894, p. 713.

420 Opin. Atty-Gen. 391; see also 14 Opin. Atty-Gen. 522 and 19 Opin. Atty-Gen. 377.

- Rev. Stat., Sec. 4103.
} 
pardon being that the convicts should be confined in prison in the United States, which was done.

Friend. if settlement out of court

The offenders in minor crimes may make pecuniary or other settlement with the persons they have injured, and, if made with the approval of the minister or consul, such a settlement is binding. ${ }^{1}$

\section{IV-MISSIONARIES}

Impore tance of rights of missionaries
American policy. non-religious
Upon no other subject is the printed diplomatic correspondence of the United States so voluminous as upon that of the protection of missionaries in oriental countries. This results only in small part from native antagonism to a new religion. The main reasons are that, except in the principal seaports, the American missionaries have far outnumbered all other classes of Americans combined; that nearly all the missionaries have resided and travelled in the interior and penetrated into parts of the country where foreigners have very seldom or never been seen; that the relations of the missionaries with the native inhabitants have been much closer and more general than those of the mercantile classes; that special privileges not stipulated in the treaties have been allowed to missionaries above those granted to foreigners in other occupations; that local officials have often been less generously disposed toward the missionaries than the central authorities have been; and that, whereas some missionaries have been too little guided and restrained by the church organization to which they belonged, others have, under highly organized ecclesiastical control, assumed powers in some instances which interfered with the prerogatives of the local government.

It has been the uniform policy of the United States to secure equal privileges and protection for all its citizens abroad, irrespective of class or creed; nevertheless, in dis-

1 Rev. Stat., Sec. 4099. 
cussing the situation of missionaries, as in Turkey and China, it is well to remember that many of the privileges which they enjoy, under treaty and usage, are the emanation of the special relations that have existed between some of the European governments and certain ecclesiastical organizations. France is the chief protector of Roman Catholics in both Turkey and China. Russia protects Greek Catholics. Even Great Britain and Germany are traditionally obligated to defend the great faiths which are so closely connected with their national history. All these European states protect their own subjects or citizens in the Orient, whatever may be their religious belief; but, when the oriental governments have granted special privileges to foreigners engaged in propagating religion, as both Turkey and China have often done, it has been necessary to take into account the intimacy and coöperation between the ecclesiastical and political agencies of some of the European governments. In the treaties themselves no sectarian preferences are named, but in Turkey the entire law of persons is built upon the adhesion of individuals to one or another religious belief, and in China, upon one or two occasions at least, privileges have been extended first to one religious organization and only later or not at all, to others. China is a secular state, liberally tolerant of all religions. Turkey is a state founded on Mohammedanism, with the Sultan as the successor of the Prophet and head of the Mohammedan world; yet Turkey has for several centuries been tolerant of other religions and was conspicuously so at the period when the struggles for religious liberty in western Europe were most bitter and bloody. In the nineteenth century the jealousies of various religious sects in Turkey, their interference in purely political affairs, and the weakened financial condition of the country obscured the actually extensive religious freedom granted by the Ottoman government. Under these circumstances, the United States, having no obligation to secure privileges and protection for one form of religion above another, and treating with the oriental states in this regard 
with only the plain object of securing religious freedom, may be said to have had a really distinctive policy: that of protecting American missionaries to the same degree as other American citizens. ${ }^{1}$

Religlous toleration in Turkey under the treaty of Berlin, Aiticle I.XXI1
Regulations disallowed
The broad basis upon which rest the principal religious rights enjoyed in T'urkey at the present day is the treaty of Berlin, July 13, 18\%8. Article LXXII reads as follows:

The Sublime Porte having expressed the intention to maintain the principle of religious liberty and give it the widest scope, the contracting parties take notice of this spontaneous declaration.

In no part of the Ottoman Empire shall difference of religion be alleged against any person as a ground for exclusion or incapacity as regards the discharge of civil and political rights, admission to the public employments, functions and honors, or the exercise of the various professions and industries.

All persons shall be admitted, without distinction of religion, to give evidence before the tribunals.

The freedom and outward exercise of all forms of worship are assured to all, and no hindrance shall be offered either to the hierarchical organizations of the various communions or to their relations with their spiritual chiefs.

Ecclesiastics, pilgrims, and monks of all nationalities traveling in Turkey in Europe, or in Turkey in Asia, shall enjoy the same rights, advantages, and privileges.

The right of official protection by the diplomatic and consular agents of the powers in Turkey is recognized both as regards the above-mentioned persons and their religions, charitable and other establishments in the holy places and elsewhere. ${ }^{2}$

The more specific statements of the rights which missionaries have invoked are contained in the laws of the Turkish

${ }^{1}$ A general discussion of the rights of American missionaries in Turkey was made by Mr. Bayard, For. Rel. 1887, p. 1094; by Mr. Blaine, For. Rel. 1891, p. 765; by Mr. Foster, For. Rel. 1892, p. 609; by Mr. Olney, For. Rel. 1895, pt. 2, p. 1256, 1461.

For early instances of toleration see Mr. Oscar Straus's Roger Williams, The Pioneer of Religious Liberty, New York, 1894, p. 132-3, 201-2.

An excellent statement of the rights of missionaries in China was made by Rev. Henry Boldget, for many years a missionary there; For. Rel. 1885, p. 153 . A general discussion of the question was made by Mr. F. F. Low, For. Rel. 1871, p. 97; by Mr. J. C. B. Davis, For. Rel. 1871, p. 153; by Mr. G. F. Seward, For. Rel. 1876, p. 46; by Mr. Chester Holcombe, For. Rel. 1882, p. 137; by Mr. Charles Denby, For. Rel. 1888, pt. 1, p. 270; 1895 , pt. 1, p. 196.

'Translation from the original French given in For. Rel. 1892, p. 610. 
Empire. Any such law not consonant with the privileges established by treaty and by usage, it has been the uniform practice of the foreign governments through their ministers at Constantinople to disallow so far as affecting the privileges of their own subjects or citizens. The difficulties that have arisen have been mostly due to a misunderstanding of the precise requirements of the law or irregularity in the administration of it in localities distant from the capital.

Many missionary stations are situated far from Constantinople. The right to reside anywhere in the empire ${ }^{1}$ and freely to travel from place to place ${ }^{2}$ is undeniable, and the exercise of these rights is in practice limited only by the prudence of keeping within localities where security and protection are readily obtainable.

In 1891 the Turkish government complained that the dwelling houses of missionaries were being used for public worship and for instruction, but the language of the complaint was very general and no criterion was suggested by which the public and the private use of such buildings could be distinguished. The United States, while declining to acquiesce in any proposition under which Turkish authorities might infringe upon the domiciliary rights of American citizens, expressed the desire that missionaries should keep strictly within the rights of alien domicil by refraining from inviting the attendance at their houses of natives in greater numbers and more frequently than the commonly understood bounds of private hospitality permitted. ${ }^{3}$

In a case where a missionary, who owned a piece of real property, desired the Turkish authorities to issue a building permit for the erection of a dwelling house, and the permit was temporarily refused on the ground that the missionary would not bind himself not to use the house for school purposes, the Department of State held that the requirement that the special uses of a building other than an or-

\footnotetext{
${ }^{1}$ For. Rel. 1887, p. 1094; 1892, p. 609; see also For. Rel. 1883, p. 871.

For. Rel. 1898 , p. 1095.

Bor. Rel. 1891, p. 755, 757, 765; 1892, p. 527, 530, 531.
}

Rights of residence in interior

Use of dwelling houses as churches and schoois 
dinary habitation should be defined with reasonable precision, could not be allowed to restrain foreigners from the enjoyment of all immunities of domicil. ${ }^{1}$

The acquisition by missionaries of certain real property through a native agent and in his name, with the object of avoiding a higher purchase price, elicited the suggestion of the American authorities in 1894 that the rights of citizens could probably be better asserted and more practically defended if the land were recorded in the name of the American owners. The difficulties in this case arose only when building permits were applied for. ${ }^{2}$

Domlclllary right:

Turklsh school regulations
During the absence of a missionary from his household and school premises at Tarsus in 1895 the premises were entered by a group of armed men, not soldiers, who severely attacked the servants left in charge. Arrests were promptly made, but, after a farcical trial, the local judge released the prisoners. To support the remonstrances of the American representatives a naval vessel, the Marblchead, was sent to Mersine, a neighboring port. The Turkish government then dismissed the judge at Tarsus and convicted eight of the accused persons. ${ }^{3}$ When the central Ottoman authorities were apprised of the entrance of police officers into the house of an American missionary at Marash in 1895 under the direction of the acting governor and without notification to a consul or for any of the causes named in the real estate protocol of 1874 , a prompt reprimand was given to the officials responsible for the outrage. This invasion of domicilary rights had been the more serious because the government officials had themselves participated in it."

The American missionaries and the natives under their supervision conduct an extensive system of schools. The flrst school was opened at Beirut, Syria, in 1824. Of schools of all grades there were in 1904 more than 5\%0, with an at-

1 For. Rel. 1891, p. 755; see also 1892 , p. 547,550, 553, 556.

- For. Rel. 1894, p. 693, 698; see also For. Rel. 1893, p. 625, 632.

- For. Rel. 1895, pt. 2, p. 1258.

- For. Rel. 1895, pt. 2, p. 1252; see also For. Rel. 1892, p. 601. 
tendance of more than $2 \%, 800$ students and pupils. There are several colleges, among them the well known Robert College at Constantinople.

For many years the Turkish government regarded the schools merely as auxiliary to religious establishments which, by ancient right, were exempt from local jurisdiction. But in 1869 a special school law was decreed. Under this law schools, other than those established by the government, can be opened only upon permit received from the ministry of public instruction certifying government approval of the course of study, text-books and teachers. ${ }^{1}$ Since the question of issuing permits for schools has in practice been left chiefly to the local authorities, there has been much variation in the administration of the school laws, and in some cases schools have been summarily closed even when it was believed that the law had been complied with. In 1887 it was learned that new and severely stringent regulations for schools were about to be decreed. The American minister, Mr. Straus, so informed his colleagues and, with their support, convinced the Grand Vizier of the inadvisability of issuing regulations that would seriously and materially infringe upon the rights of foreigners under the treaties and the fundamental laws of Turkey. In the same year Mr. Straus made a journey through Syria, incidentally reëstab. lishing amicable relations between the school authorities and the native officials in that quarter, and bringing about so general a reopening of schools that his government expressed to him its special gratification. ${ }^{2}$

According to the regulations of 1863 for the practice of medicine, which are believed still to be in force, a certified diploma of graduation from a medical school must be presented to the Imperial Medical College at Constantinople Licensing of graduates in medicine and a colloquium before the faculty of this college must be

${ }^{1}$ Aristarchi, Légisiation Ottomane, vol. 3, p. 299, Art. 129, 130.

${ }^{2}$ For. Rel. 1888, pt. 2, p. 1590, and passim; a memorandum by Rev. H. O. Dwight, who for many years was the principai agent of the missionaries in Turkey in their correspondence with the legation, Is printed in For. Rei. 1887, p. 1085; see also For. Rel. 1885, 1888, pt. 2, 1889, 1890, 1891, 1892, 1893, 1894, 1895, 1897 passim. 
Turkish regulations upon printing and circulating books

passed before the practice can be entered upon. These regulations apply equally to graduates of foreign schools and to graduates of the American Medical College at Beirut. ${ }^{1}$

Since 1834 American religious societies have been continuously importing or printing books and circulating them in Turkey. Although no restriction upon this form of business is to be found in the capitulations or treaties, the Turkish government has subjected it to an almost prohibitory inspection and regulation. Books published in Turkey are censored by the ministry of public instruction and may appear only under its authorization printed on the titlepage; imported publications also are required to bear an inspector's stamp. Compliance with these requirements is assumed to permit the free circulation of the book throughout the empire, but as a matter of fact officials in the provinces, paying little heed to the authorization given at Constantinople, have detained shipments of books and mutilated or destroyed them. Although particular abuses have been rectified, the Porte, vexed by the rivalries of various religious sects, old and new, and fearful of opening the way to propagandists of political revolution, has countenanced a very severe and sometimes irregular enforcement of the publication laws. On January 10, 1888, the government promulgated a new law, intended to take the place of the law of January 21, 1858; but, as it seriously conflicted with the rights of foreigners, the representatives of the powers at Constantinople, after due consideration, declined to admit its application to persons under their jurisdiction. An objectionable feature of the new law was its fifth article, which provided that a foreigner should not be permitted to set up a printing office, except upon furnishing a declaration legalized by the embassy or legation of his country, whereby he should, in his profession as a printer, relinquish his extraterritorial privileges and immunities and accept the proceedings which are prescribed for Ottoman

\footnotetext{
${ }^{1}$ For. Rel. 1898, p. 1101 ; also 1872 , p. $672 ; 1884$, p. 553,$561 ; 1889$, p. 707, 712; 1893, p. $637,650,702$.
} 
subjects. The Secretary of State, Mr. Bayard, in approving the protest sent by Mr. Strans and his colleagues to the inperial ministry, referred to certain legislation of SpanishAmerican countries which had sought to establish that a foreigner, while continuing in his allegiance to his own country, might waive his right to its protection, and stated the position of the United States to be that it was not competent for a citizen to divest himself of any part of his inherent right to protection, though he might conclude his rights in that regard by ceasing to be a citizen. The proposal was even more objectionable in that it sought to make the American government, through its diplomatic representative, a consenting party to the renunciation. ${ }^{1}$

In 1894 certain native teachers in American schools at Aintab and Marash were arrested upon suspicion of sedition. This gave rise to an apprehension lest other arrests of such Protection of native teachers teachers might be made to the serious injury of the missionary schools throughout the empire. In consequence of representations made by the American minister, Mr. A. W. Terrell, the Ottoman Porte permitted a representative of the legation to be present at the investigation of the charges against the teachers, a concession which was regarded by the Department of State as affording ample opportunity for the examination of complaints of capricious arrests or of the vexatious hindrance of the legitimate operations of the schools. In the case at Aintab the search for papers in the school building was not made until American representatives were present. ${ }^{2}$

It has been held that claims of indemnity for destroyed property of native teachers, if such property be not personal belongings, but only the actual and necessary adjunets of work in the American schools, may be properly presied. ${ }^{3}$

\footnotetext{
1 For. Rel. 1888, pt. 2, p. 1594. In For. Rel. 1890, p. 754 the conditions of the missionary book trade in general are described by Rev. H. $O$. Dwight. See also For. Rel. 1883, 1885, 1888, pt. 2, 1890, 1891, 1892, 1893 passim.
}

2For. Rel. 1894, p. 740; see also 1892, p. 568, 576; 1895, pt. 2, p. 1281.

- For. Rel. 1896, p. 882. 
Indemnities for mission property destroyed

In 1893, when there was apprehension of revolutionary disturbances, and in 1895, when the Turkish government was using severe measures to repress an incipient Armenian revolution, certain school buildings at Marsovan, Harpoot and Marash, used by American missionaries, were destroyed by fire. It was proved that the burning of Marsovan College was done at the instigation of a local Turkish official, and that his subordinates started the conflagration.

The burning and phundering of the missionary buildings at Harpoot in February, 1895 furnished a still clearer case of responsibility on the part of the Turkish government. ${ }^{1}$ The fires were started by Kurds in the presence of Turkish soldiers, who refused assistance until eight buildings and the personal property of eleven missionaries and of a larger number of native helpers had been destroyed or carried off. The total loss was $\$ 13,700$ in buildings and $\$ 29,734$ in the personal property of the missionaries.

In Norember, 1895, missionary school buildings at Marash were destroyed by fire under circumstances similar to those at Harpoot and with the additional circumstance that the missionaries had formally requested the local government for a special guard two weeks before the burning and plundering of the buildings occurred. ${ }^{2}$ The value of property destroyed at Marash was $\$ 10,560$.

The Turkish government denied its responsibility for the losses at Harpoot and Marash on the ground that they were occasioned by political disturbances and that the local authorities had exerted every effort to stop the conflagrations. $^{3}$ The United States declined to admit this contention since there was abundant proof of the participation or connivance of the Turkish authorities. "No room is discernible," said Secretary of State Olney, "for the application of the limited and jealously qualified rule of international law relative to the responsibility of a government for the

1 For. Rel. 1896, p. 895.

- For. Rel. 1895, pt. 2, p. 1369, 1416.

- For. Rel. 1896, p. 886, 894. 
acts of uncontrollable insurgents. The negligence of the authorities and the acts of their own agents are here in question, not the deeds of the Kurds, nor still less of the supposed Armenian rebels on whom the Porte seems to seek to throw the responsibility of these burnings and pillagings." 1

When the Armenian troubles of 1895-6 were first breaking out, the American minister at Constantinople, Mr. A. W. Terrell, took the precaution to ask the Ottoman Porte for special guards for a number of American missionary stations, and he also gave notice that the United States would continue to expect and require full security for its citizens in Turkey. The Turkish government, though guilty of some neglect and delay, on the whole exerted itself to an extraordinary degree. The American missionaries, through their government, testified their appreciation of its action and particularly of the courageous conduct of certain Turkish officials and Turkish troops in defending them in various cities in Syria and eastern Turkey. During the disturbances there was also special coöperation between the British, German and American consuls in places distant from the principal cities. The American naval vessels, Marblehead, Minneapolis and San Francisco were sent to Turkish waters and their officers placed in direct communication with the localities where trouble had been threatening or had occurred. The missionaries were advised to use their own judgment as to abandoning certain stations for a time, and the Turkish government agreed to furnish military escorts when desired; but the missionaries, feeling personally responsible for the care of the property at their interior stations, and finding their charities to be so much needed by those afflicted communities, were universally of the opinion that it was their duty to remain at their posts. At no time during the seventy years and more that American missionaries had been residing in Turkey had they been

For. Rel. 1896, p. 893, 897. A different opinion was taken by Secretary of State Bayard; For. Rel. 1885, p. 858.

Measures of protection dur. ing Armenian dis. tur-

bances 
in greater danger, and never was the purely charitable nature of their work, nor their rectitude and prudence, more clearly shown.

Missions In Persia
Religious toleration under the treaties of 1858 with China
American missionary enterprises in Persia appear at all times to have been liberally treated by the government of the Shah. The missionaries maintain hospitals in the principal cities ${ }^{1}$ and conduct schools in many parts of the country. The restrictions upon publishing and circulating books are only nominal. ${ }^{2}$ Occasional difficulties, caused by the ignorance or animosity of local authorities, have been promptly rectified by the central government. ${ }^{3}$ At the same time the government has declined to permit the opening of schools in localities where serious opposition was apprehended.* When the missionaries have given assistance to Jews who were being persecuted by native religious sects, the Persian government has coöperated with them $;^{5}$ and when missionaries from eastern Turkey, as well as many native Turks, sought refuge across the Persian border in 1896, the Persian government took special measures for their protection. The customary domiciliary rights in Persia are alleged to be even more considerable than in Turkey, but the United States has not on that account permitted its citizens or its diplomatic representatives to extend asylum. ${ }^{7}$ Real property in Persia may be owned by missionary societies in their own names. ${ }^{8}$

The treaties made with China soon after the British war of 1839-42 did not mention religious toleration. The treaties of 1858, however, devoted an article to the subject. Article XXIX of the American treaty, after reciting that the Christian religion, as professed by the Protestant and Roman Catholic churches, taught men to do good and

For. Rel. 1887, p. $914 ; 1889$, p. 648.

- For. Rel. 1897, p. 427.

- For. Rel. 1884, p. 402; 1887, p. 916; 1893, p. 480.

- For. Rel. 1894, p. 486, 488, 491.

- For. Rel. 1894, p. 492.

- For. Rel. 1896, p. 466; see also 1888, pt. 2, p. 1362.

'For. Rel. 1894, p. 492, 497, 503, 606.

- For. Rel. 1892, p. 355. 
to do to others as they would have others do to them, stipulated that persons professing and teaching those doctrines should not be persecuted on account of their faith, and that no person, whether an American citizen or a Chinese convert, peaceably teaching and practising Christianity, should be interfered with or molested. By Article IV of the Burlingame treaty of July 28,1868 , the scope of this toleration was enlarged by the declaration that persons of "every religious persuasion" should enjoy "entire liberty of conscience," and should be "exempt from all disability or persecution on account of their religious faith or worship in either country."

These provisions for many years formed the basis of missionary rights in China. From time to time the government of China, recognizing the unselfish and beneficent work of the missionaries, made special concessions in their favor and issued imperial edicts for their special protection. ${ }^{1}$ In $1895^{2}$ and $1899^{3}$ the French government, which has charge of protecting Roman Catholic interests in China, obtained the confirmation of certain missionary privileges in the interior, which, until then, had rested mainly upon usage and upon special instructions to provincial governors. The British treaty of September 5, 1902 simply states that Great Britain agrees to join in a commission for the investigation of the missionary question, should such a commission be formed by China and the treaty powers.

The American treaty of October 8, 1903, embodies the provisions of Article XXIX of the treaty of 1858 and adds the following:

No restrictions shall be placed on Chinese joining Christian churches. Converts and non-converts, being Chinese subjects,

I In 1896, through the action of the French minister to China, $M$. Gerard, the Tsung-li Yamên was persuaded to order the expunging from the Chinese code of all clauses restricting the propagation of Christianity; For. Rel. 1896, p. 87.

${ }^{2}$ Decree of August 9, 1895, Brit. and For. State Papers, vol. 87, p. 1214.

${ }^{3}$ Decree of March 15, 1899, Jour. du droit internat. prive, 1902, p. 190-2; also infra, p. 127. 
shall alike conform to the laws of China; and shall pay due respect to those in authority, living together in peace and amity; and the fact of being converts shall not protect them from the consequences of any offence they may have committed before or may commit after their admission into the church, or exempt. them from paying legal taxes levied on Chinese subjects generally, except taxes levied and contributions for the support of religious customs and practices contrary to their faith. Missionaries shall not interfere with the exercise by the native authorities of their jurisdiction over Chinese subjects; nor shall the native authorities make any distinction between converts and nonconverts, but shall administer the laws without partiality so that both classes can live together in peace.

Missionary societies of the United States shall be permitted to rent and to lease in perpetuity, as the property of such societies, buildings or lands in all parts of the Empire for missionary purposes and, after the title deeds have been found in order and duly stamped by the local authorities, to erect such suitable buildings as may be required for carrying on their good work.

These new stipulations cover the principal missionary difficulties that have arisen since 1858, namely, the right to acquire real property in the interior of China and the rights of Chinese converts. The treaty is therefore of great importance.

Rlght to reside in the interior

Right to acquire properin the interior

It will be observed that the right of missionarics to reside in the interior is not included in this treaty. The omission may be ascribed to the fact that the privilege has long existed, the only restrictions upon it being made by the authorities in remote communities where friendliness may not yet have been manifested. When missionaries have taken up their residence in a community without opposition on the part of the people, the local authorities, though personally indisposed toward them, have been instructed from Peking to afford protection and assistance. ${ }^{1}$

The stipulation that missionary societies of the United States shall be permitted to rent and lease in perpetuity buildings or lands in all parts of the Empire for missionary purposes put an end to the often recurring discussion of

${ }^{1}$ For. Rel. 188s, pt. 1, p. 270; see also 1882 , p. 137 ; 1885 , p. 147; 1895, pt. 1, p. 196. 
how far the United States would sustain the claims of missionaries to the enjoyment of real property privileges obtained by special grant and usage. ${ }^{1}$ In extending the priviIege to missionary societies and not to individuals the government of China obviates the difficulties which have heretofore arisen concerning acquisitions of real property by very diverse and sometimes undesirable methods, as, for instance, in the name of a Chinese subject who bound himself to his foreign principals by a covenant of trust. And in stipulating that the use of the property shall be for missionary purposes alone, the Chinese government, at least impliedly, requires that missionary property shall not be used for any agricultural or industrial pursuits, unless these pursuits are merely adjuncts of religious and charitable work, as for the support of students in mission schools. ${ }^{2}$

There has been comparatively little difficulty in China connected with the maintenance of missionary hospitals, orphan asylums, elementary schools and similar institutions, and this beneficent work has been very extensive. The government of China and its provincial representatives have, with very inconsiderable exceptions, uniformly and generously approved it. Their approval has also been given to the several colleges established by missionaries.

A matter of very great difficulty in China has been the position of native Christian converts relative to other Native Chinese, to the local government and to the missionaries. "For a Chinaman to accept Christianity," wrote an American minister to China in 1885 , "involves so complete a surrender of all that belongs to his education, his theory of government and society, his views of nature, his ancestral worship, his domestic relations, and his modes of life, that it is a wonder that a convert is made."3 Yet the number of these converts has increased and is increasing very rapidly; in 1904 the estimated number of Protestants was 112,000 and of Roman Catholics at least 500,000. Most of these are

For. Rel. 1888, pt. 1, p. 270.

' For. Rel. 1897, p. 105.

sor. Rel. 1885, p. 149. 
from the humbler classes. Their abstention from participating in certain village festivals, which they regard as involving heathen ceremonies, results in largely diminishing the funds gathered by officials as a form of tax for the

Mr. Angell's action support of such festivals. As long ago as 1862 the French minister persuaded the imperial authorities to issue an edict exempting the Roman Catholics from such taxation, and though the authorities were thought to be willing to give the same exemption to other Christian converts, they were not moved to do so formally until 1881, when the American minister, Mr. J. B. Angell, availed himself of a favorable opportunity to make the request. ${ }^{1}$ From time to time the local anthorities have refused to Chinese converts the privilege of entering the Chinese government examinations, but such refusal does not appear to have been approved by the central government and it is clearly a violation of the treaties. ${ }^{2}$ The molestation of native converts has sometimes taken the form of intimidation by means of placards as well as the form of refusing to protect them against personal violence and the destruction of their property. The central government has in such cases directed the local officials to afford protection and redress. ${ }^{3}$ In a number of cases complaint has been made that disreputable characters have become converts with the object of obtaining missionary assistance in criminal prosecutions to which they were liable. American missionaries lave very seldom, if ever, exposed themselves to the charge of interfering to protect such Chinese from the ordinary course of justice, whatever they may have done to assist them in securing an impartial trial. ${ }^{4}$ The relations between the missionaries and their converts are, however, so close that difficulties involving rights of the converts have often resulted in infringements upon the rights of the missionaries and experience has shown it to be necessary to make very specific treaty stipulations on these points.

2 For. Rel. 1881, p. 272.

${ }^{2}$ For. Rel. 1897 . p. 82 ; see also For. Rel. 1871, p. 153; 1881, p. 308.

For. Rel. 1s96, p. \&4.

- The imperial Chinese regulations for official intercourse between 
The educated and official classes of China, being Responnaturally conservative in regard to the introduction of new religions, have often been supposed to be actively antagonistic to them, but their attitude appears on the whole to have been one of indifference. The central government has repeatedly affirmed its purpose to maintain the full toleration granted by the treaties, but its local representatives have not, until recent years, been made to feel their responsibility for the preservation of order in communities in the interior where foreign missionaries have been permitted to reside. An erroneous idea has, to a considerable extent, prevailed among the officials and the people that payments of money afforded complete satisfaction for all injuries, so that the punishment of those who have participated in anti-foreign riots has seldom been so prompt and severe as it should have been. In 1895 two very bloody outrages were suffered by American and other missionaries, and a commission sent by the United States to investigate them, reported that certain provincial authorities, mentioned by name, had grossly and culpably neglected to use their influence and the means at their disposal to prevent the outbreak of violence. At the suggestion of the Acting Secretary of State, Mr. W. W. Rockhill, the minister to
China, prepared a note to the Tsung-li Yamên, proposing certain measures considered desirable for preventing the recurrence of anti-foreign riots. ${ }^{1}$ The third and fourth propositions were as follows:

3. The determination of and formal declaration by China by Imperial decree to hold responsible and promptly punish not only all individuals or minor officials directly or remotely involved upon the occurrence of any riot whereby peaceable American citizens have been affected in person or property or injured in their established rights, but also the viceroy or governor of the province in which it has occurred, who is directly responsible

local authorities and Roman Catholic missionaries are printed in Rockhill, Treaties Relating to China and Korea, p. 424.

${ }^{1}$ For. Rel, 1896 , p. $57,63-4$. 
to the Throne for the acts and omissions of every one of his subordinates, although his only fault may be ignorance.

4. That the punishment of officials found guilty of negligence in case of a riot, or of connivance with rioters, shall not be simply degradation from or deprivation of office, but that they shall be, in addition, rendered forever incapable of holding office, and shall also be punished by death, impriscnment, confiscation of property, banishment, or in some other manner under the laws of China in proportion to the enormity of their offense.

Attitude of the

Chinese government

Missions In Korea
In reply the Tsung-li Yamên conceded that the local authorities should be punished for failing to take precautionary measures to prevent riots, but declined to hold the viceroys and governors responsible. Mr. Denby then very urgently warned the Tsung-li Yamên of the imminent loss of character and respect, not to speak of financial embarrassment, which China would suffer if the viceroys and governors, who had undoubted power to prevent the riots, were not made responsible. ${ }^{x}$ In the light of the events of 1900 the timeliness of this warning is apparent, and it is believed that the advisability of adopting the proposition can no longer be doubted.

The hesitancy of the Chinese government to take definite action until forced to do so is well illustrated by the imperial decree of January 15, 1898, ${ }^{2}$ which summarizes the missionary situation as follows:

Since the removal of the prohibition of Western religion Christian places of worship are found in almost all parts of the Empire, foreign missionaries proselytize in sight of each other, and the number of Chinese converts increases from day to day and month to month. One false step by local officials in dealing with them gives rise to embarrassments at home and abroad. Beyond doubt this question has an important bearing on the peace of the State, and caution is absolutely necessary.

While the efforts of missionaries to establish schools and hospitals in the open ports of $\mathrm{Korea}^{3}$ appear to have met

${ }^{1}$ For. Rel. 1897, p. 67.

- Brit. and For. State Papers, vol. 90, p. 341.

- For. Rel. 1884, p. 127; 1886, p. 222. 
with no disapproval on the part of the Korean government, a positive disinclination has been manifested toward religions proselytism, particularly in the interior. ${ }^{1}$ 'The American treaty with Korea of May 22, 1882, does not grant the privilege of residence in the interior, but the privilege has been enjoyed with the acquiescence of the Korean government except in the remote interior. It has been asserted that the treaty of June 4, 1886, between France and Korea permits freedom of travel in the interior on passports, since it omits the restrictions of such travel to purposes of 'pleasure' and 'trade' contained in the treaty of $\mathrm{No}_{0}$ vember 26, 1883, between Great Britain and Korea. ${ }^{2}$ In the very few instances in which missionaries and their native helpers have been molested the Korean government has caused immediate reparation and the dismissal from office and punishment of the local officials responsible for the failure to give protection. ${ }^{3}$

Missionaries to Siam have no privilege under treaty to establish themselves in the interior of the country. A formal request made in 1884 that such a privilege be granted for a particular mission station was not directly granted by the central government but was referred to the local viceroy. ${ }^{4}$

In 1889 the Siamese govermment liberally donated property in Ratburi for the establishment of a mission hospital. ${ }^{5}$

\section{V-REAL PROPERTY}

The American treaties with China of 1844 and 1858, re- Land sembling the British and other treaties of approximately the same dates, provide that American citizens shall enjoy all proper accommodations in renting and occupying land within

Missions in Siam

\footnotetext{
1 For. Rel. 1888, pt. 1, p. 444, 446, 447.

2 For. Rel. 1901, p. 396.

s For. Rel. 1901, p. 387; 1903, p. 626.

- For. Rel. 1884, p. 453, 454, 461.

- For. Rel. 1889, p. 657.
} 
definite boundaries at the open ports. Insistence upon the acquisition of any particular site is forbidden. Under these provisions certain small areas, each of them less than a mile square and situated apart from the crowded districts of the Chinese cities, were selected by the mutual agreement of the consuls and the local representatives of the imperial government, and within these areas leases of property in perpetuity were made to American citizens nnder the registration and seal of the Chinese authorities and the American consuls.

To prevent unreasonable restrictions upon the renting of land for suburban residences-there had been much demand for such residences near Canton, Shanghai and Tientsin-the treaty of 1858 between Great Britain and China was made to contain the words 'at other places' after the words 'treaty ports.' The right to rent land 'at other places' has occasionally been claimed by foreigners to include the right to rent land anywhere in the interior, but no government has given countenance to such a strained interpretation of the expression. ${ }^{1}$

Undesirable methods of acquiring land in the interior
The desire to acquire land in the interior has, however, been so insistent that some individuals have remained in the interior under the protection of travel certificates for longer periods than those certificates were legally good and have then claimed the right by sufferance to rent land in perpetuity, notwithstanding they were supposed to be occupying it only temporarily. Other persons have used the name of a Chinese in acquiring land, securing themselves by a covenant of trust; but such a trust, being an undertaking to circumvent the treaty, had, of course, no legality. This latter undertaking is to be distinguished from that of financially or otherwise assisting a Chinese commercial agent or missionary helper to aequire land in his sole and unrestricted right while continuing his services in furthering the enterprises of his principals. ${ }^{2}$

For some time after the ratification of the treaty of

1 For. Rel. 1881, p. 282, 316.

- For. Rel. 1881, p. 308. 
October 25, 1860, between France and China, the opinion prevailed that under its sixth article, as given in the Chinese text, missionaries were permitted to reside in the interior and rent property there. This misapprehension was due to the interpolation into the Chinese text of the words: "It is in addition permitted to French missionaries to rent and purchase land in all the provinces and to erect buildings thereon at pleasure." No such words appeared in the French text of the treaty, and the French text was declared to be the original. ${ }^{1}$

On the other hand the Chinese government has more and more frequently given special authority to its officials in various localities to permit missonaries to acquire land; and if, unfortunately, the missionaries have subsequently been molested in the enjoyment of their special privileges and their property has been destroyed, the American government has demanded for them protection and indemnity. ${ }^{2}$

The privileges of renting land in the interior are said to have been granted to missionaries under the protection of France by a secret convention of 1865 , between France and China, known as the Berthemy convention. This is inferred from published French correspondence relating to the withdrawal of a regulation requiring a Chinese owner to obtain the consent of the local authorities before negotiating the lease. ${ }^{3}$

But whatever the significance of this French convention of 1865 , China has more recently granted the privilege in specific terms in the treaty of October 8, 1903 with the The American treaty of United States, a portion of the fourteenth article of which reads:

Missionary societies of the United States shall be permitted to rent and to lease in perpetuity, as the property of such societies, buildings or lands in all parts of the Empire for missionary purposes and, after the title deeds have been found in order and duly

${ }_{1}^{1}$ For. Rel. 1875, pt. 1, p. 334; 1886, p. 96.

2 For. Rel. 1882, p. 132; 1888, pt. 1, p. 270; see also For. Rel. 1880, p. 298; 1893, p. $230,233$.

${ }^{3}$ De Clercq. Traités de la France, vol. 20, p. 233; see also supra, p. 119. 
stamped by the local authorities, to erect such suitable buildings as may be required for carrying on their good work.

No general privilege of this kind has been extended to commercial companies or to individuals, but if in the future it is so extended to the subjects or citizens of any other power, it will be equally extended to American citizens by virtue of most-favored-nation clauses in the American treaties.

As to the legal principles and forms under which foreigners acquire and hold land in China, it may be observed that it has been held in an English case ${ }^{2}$ that the principle that the title to realty is governed by the lex loci is not affected by the rights of extraterritoriality. A British consular court before which real property rights are being litigated is to be governed in this respect by the Chinese law and usage.

It would seem inevitable, however, that legal difficulties in litigation over real property held by foreigners in China should continue to multiply until, with the reorganization of the Chinese system of jurisprudence, the jurisdiction of real property is left to Chinese courts. ${ }^{3}$

No privileges of owning or renting real estate in Japan were granted to foreigners by treaty, except the privilege of renting in the foreign concessions at certain open ports. By the laws of Japan no Japanese could sell land to a foreigner or give title-deeds as security. ${ }^{*}$

1 The British treaty of September 5, 1902, had granted no new privileges in respect to acquiring real property; For. Rel. 1903, p. 551.

2 Macdonald $\because$ Anderson, British Consular Court at Tientsin, January 16, 1904, North China Herald, vol. lxii, February 5, 1901, p. 247-50. The opinion in this case contains an excellent discussion of the principle by Mr. Justice F. S. A. Bourne; a portion of the opinion is printed infra, Appendix VIII. A similar judgment was given in Secretary of State v. Charlesworth Pilling and Co., in 1901; Law Times Reports, vol. 84, N. S. p. 212.

'In 1856 an American assigned his real property in Canton to a BritIsh banking corporation for the benefit of the creditors of Nye Brothers and Co., and foreclosure proceedings took place under direction of the British authorities, the American authorities consenting. This was apparently contrary to the rule of suing the defendant in the court of his consul. Sen. Ex. Doc. 22, p. 989 (vol. 9), 35 th Cong., 2d Sess.

- For. Rel. 1873, pt. 1, p. 665. 
In contrast with the rule existing in China that jurisdiction of real property rights is to be given to the court of the defendant's nationality, there is the rule existing in 'Turkey that in respect to the real property a foreigner acquires in that country he is subject to Turkish jurisdiction.

It appears that it was the Turkish claim of exceptional jurisdiction over foreigners who held real property, and not an actual denial of the privilege of acquiring it, that caused Turkish claims of jurisdiction them generally to abstain from such acquisition. The authorities upon Turkish law declared that a foreigner holding land in Turkey was obliged to pay not only a land tax, but also a personal tax, and thus to accept approximately the same standing before the law as a zimmi or non-Moslem subject of the Sultan. Against the imposition of such taxes the foreign merchants permanently established in the Turkish ports had been protected only with difficulty, as the frequently repeated inhibitions of the capitulations testify; and the same difficulty led to the inscrtion of a provision in the French ordinance of 1781 that subjects of France were forbidden to acquire real property in Turkey either in their own names or under any form of partnership, except such lands and houses in the seaports as were necessary for offices, warehouses and residences.

Among the propositions of change in legislation made by the Ottoman Porte in 1856 one concerned real property. The vast areas of land held under vacouf titles, that is, lands owned by the Moslem religious organizations and leased to individuals under such complicated conditions as to make that form of tenure very undesirable and especially so for non-Moslems, were, to a large extent, to be placed under a more simple and definite system. More lands were to be made available under fee simple or mulk titles by opening to acquisition by individuals large tracts owned by the Sultan, and acquisition under mulk titles was to be otherwise systematically encouraged.

But in exchange for introducing these improvements and admitting foreigners to the enjoyment of them the Ottoman Porte demanded of the powers a denunciation of the capitu-

Improvenent of Turkish real

property law
Origin of the real property privi- 
lations. This was a manifestly impossible condition. Soon after the admission of Turkey to the European concert in 1856 that government had so cruelly dealt with a threatened uprising in Syria as to cause horror throughout the civilized world; and the dread of permitting Turkey to increase its authority over foreigners and their property appeared to remove all possibility of coming to an agreement. However, the financial difficulties of the Turkish government, which, in the early sixties, were so great as to require one-third of the annual revenue to pay interest and amortisation, and the willingness of the government of France to take some measure to get better security for the very large loans its subjects had made to Turkey, brought France and Turkey to a compromise. In 1867 the government of Turkey extended the right of foreigners to hold real estate in Turkey upon condition that their governments would make a partial restriction of their extraterritorial rights. France accepted the conditions by signing a protocol with Turkey, June 9, 1868 , and Great Britain accepted them in the same manner July $28,1868 .^{1}$

Nature of the real estate rescript of 1867

The imperial rescript of January 18, 186\%, ${ }^{2}$ provides that foreigners, ${ }^{3}$ proprietors of all real property in Turkey are, in consequence of the enjoyment of that privilege, placed upon terms of equality with Ottoman subjects in all matters relating to their real property. The legal effect of this equality is to oblige foreigners, owners of land in Turkey, to conform to the local law in the enjoyment, transmission, alienation and hypothecation of landed property, to oblige them to pay all charges and taxes upon it, and to

1 The French text may be found in the Brit. and For. State Papers, vol. 58, p. 22.

2Padel (a dragoman of the German embassy in Constantinople), Das Grundeigentum in der Türkef nach der neueren Gesetzgebung, Jahrbuch der internat. Vereinigung für vergieichende Rechtswissenschaft und Volkswirtschaftlehre, vol. vi and vil, p. 435, 1667.

${ }^{3}$ Former Turkish subjects naturalized abroad are declared not to be included, and it is stated that a special law is to be enacted applicable to them; but they have in practice been granted this privilege and the law referred to has not been enacted; For. Rel. 1897, p. 589. It has been alleged that the law referred to was that of April 21, 1858; supra, p. 96. 
render them amenable directly and solely to the Ottoman civil tribunals in all real property actions, reserving only the immunities attached to their persons and their movable goods according to the treaties. If a foreigner, an owner of real estate, goes into bankruptcy, his assignees may apply to the Ottoman civil tribunals to obtain the sale of such part of his real estate as the law permits to be sold for the satisfaction of debts, and similarly the execution of a judgment obtained by one foreigner against another in a foreign tribunal may be effected through Ottoman authorities and tribunals to the extent allowed by Ottoman law. The privilege of making dispositions of real property by gift or by testament is restricted to such real property as the Ottoman law permits. Intestate succession to real property and succession to such real property as the law does not permit foreigners to dispose of by gift or testament, is to be governed in accordance with Ottoman law.

By the protocol of Angust 11, 1874, ${ }^{1}$ the United States accepted the conditions upon which the real estate priviThe protocol of 1874 leges were offered by Turkey. This protocol is identical with the protocols between Turkey and other powers, but it was signed later than most of them. It stipulates at the beginning that it does not interfere with the immunities specified by the treaties, which continue to protect the person and the movable property of foreigners who may become owners of real estate. It repeats the rule that the domicil of a foreigner is inviolable, but states that this immunity of domicil is to extend only to the dwelling house, the buildings appurtenant to it and the enclosures immediately about it. In localities distant nine hours or more ${ }^{2}$ from the consulate, when the necessity of so doing is urgent and for the search and proof of murder, arson, robbery and other specified crimes, the agents of the public force, with the assistance of the 'elders of the commune' and without notifying the consul, may enter the residence of a foreigner, whether or

1 The original text is in French; supra, p. 30 , footnote 2.

2 Distance is said to be commonly measured in Turkey by the rate of a walking horse. 
not he is regarded as chargeable with one of the aforementioned crimes; but, if he be arrested, his personal immunities are to be respected according to treaty and usage, and a report in detail of the domiciliary visit is to be written and immediately sent to the superior Turkish authorities and to the consul. In localities similarly distant, and with respect to controversies and offenses of a specified lesser importance, foreigners may be tried by the council of elders without the assistance of a consular delegate, but the right of appeal to the tribunal of the 'arrondissement' with consular assistance is reserved, and while such an appeal always suspends execution of the sentence of the lower court, in no case can there be a forcible execution of judgment without the coöperation of the consul. A foreigner, in whatever locality he may be, may voluntarily consent in writing to be tried before the Turkish courts without consular assistanee, but the protocol reserves his right of appeal to the tribunal of the 'arrondissement' where the trial shall proceed in the usual way.

Effect of the protocol on Jurisdiction

It was the opinion of the French ambassador at Constantinople, M. Bourée, who had a leading part in the persuading the Ottoman Porte to issue the rescript of 1867 and in giving form to the protocol proposed by the Porte to the foreign powers, that both the rescript and the protocol were applicable to owners of real estate only. ${ }^{1}$ But there is difficulty in supporting this view, for where the protocol stipulates that in certain cases foreigners may be tried in Turkish courts, with a reservation of the right to appeal, it continues: "It is well understood that all these restrietions do not concern cases which have for their object questions of real estate." The conclusion is that they do apply to other cases. But the United States has declined to admit that the protocol of 1874 forms any derogation from the rights of its citizens under the capitulations except in con-

I Van Dyck, Capitulations, p. 81; Padel, cited supra, p. 130, footnote 2 at p. 1698-701, shows what questions related to those of real estate are regarded by the Turkish Government as within its jurisdiction. 
nection with the real estate they may have acquired. ${ }^{1}$ As a matter of fact the number of consulates in the interior has been largely increased in recent years with the obvious purpose of securing better protection to foreigners. The influx of foreign capital into the interior appears to have fallen far beneath the expectations of the Turkish government. The agreement of 1904 between Germany, Great Britain and France, under which the proposed railroad from Smyrna to the Persian Gulf is to be capitalized, makes the building of the railroad in the near future probable, and this will no doubt bring much private capital into central and eastern Turkey. Under the Ottoman law persons born Ottoman subjects, Rights of who, without permission, may have become naturalized subjects of a foregn state subsequently to the law of nationality triated Turks of 1869 and then return to Turkey, do not have the right to acquire real property in Turkey. In one case the Turkish government went so far as to intimate that real property which had been nominally owned by a naturalized American citizen could not be conveyed to his sons by testament, but would at his death become the property of the state. The American minister declined to acquiesce in this proposition. ${ }^{2}$

There have been restrictions upon the acquisition by Jews, both native and foreign, of realty situated in Palestine; the object of these restrictions appears to have been to prevent acquisition by non-residents for speculative purposes or for colonization. It was the opinion of the Secretary of State that under Article XI of the Ottoman law of 1867 "a specific disability imposed upon Ottoman subjects for any cause as regards their tenure of real estate would in like manner be deemed to apply to aliens, provided no diseriminations among the several classes of foreigners were thereby made."3

${ }^{1}$ For. Rel. 1892, p. $545,554$.

${ }^{2}$ For. Rel. 1883, p. 809, 815, 821, 833 .

- For. Rel. 1898 , p. 1103,1108 ; see also 1893 , p. 638, 651, 669; 1897, p. 588. 
Right to In 1859 an American missionary purchased real property appeal in the name of an Ottoman subject, the sale having been made by order of the Turkish authorities in satisfaction of a debt, and in 1868 the deed was put into the name of the American as real owner. His title to the land was tested and found good in a Turkish court, and, upon appeal to the highest court for real property cases, was still found good; but another court ordered dispossession. Only after bringing the case to the attention of the imperial authorities at Constantinople was the title of the American owner finally confirmed. ${ }^{1}$ It would seem that an apparent miscarriage of justice in matters of real estate, even though Turkish jurisdiction be reserved, would make recourse to diplomatic action justifiable.

Privileges in Persia

In 1891 it was reported by the American minister to Persia, Mr. Truxtun Beale, that whereas the law of Persia had not allowed foreigners to hold real estate in Persia, with the result that certain American missionaries who had acquired real property in the name of a native helper had been left in the lurch by his claiming the property as his own, it had been found to be feasible to obtain the real estate privileges for Americans and secure them in the enjoyment thereof by securing the seal of the Grand Vizier upon every deed of property purchased. ${ }^{2}$

\section{VI - TAXATION}

Import and export custom duties
For the protection of commerce from extreme measures of taxation, it is usual to provide in the treaties with countries where extraterritorality prevails that the tariff of import and export duties shall not exceed a fixed maximum rate and that customs schedules and regulations shall be agreed upon.

A common stipulation in the Turkish capitulations was

${ }^{1}$ For. Rel. 1855, p. $815,843,845$; see aiso 1892 , p. 558 ; 1894 , p. 710.

' For. Rel. 1892, p. 355. 
that a certain per cent. ad valorem on imported goods was to be collected, and that, in case of dispute as to the value of the goods, the importer might pay in kind. The regulations appended to the commercial treaty of 1861 between the United States and Turkey permitted payment in kind in all instances where, the valuation of the goods not being given in the enumerated lists, a dispute as to their value arose. There is no special arrangement in Turkey, as there is in China, as to the jurisdiction of controversies arising in the adminstration of the customs laws, and questions concerning the application of the customs laws are determined in Turkish courts in the presence of the consular dragoman of the foreigner, whether he be plaintiff or defendant. There was, indeed, no suggestion in the commercial treaties of 1861-2 of derogations from the territorial sovereignty of the Porte. They were in fact the first important treaties made by Turkey which contained no stipulation as to extraterritorial privileges. The commercial treaty of 1890 with Germany is likewise of the same general tenor as ordinary commercial treaties between western powers.

The prevailing Turkish tariff on imports is eight per cent. Prohland on exports, one per cent.; and it is provided that no additional taxes shall be placed upon goods in transit to or from the interior. By the treaty of August 16, 1838 with bition of internal taxes on foreign
goods Great Britain all such taxes imposed by local governors under the form of granting teskerehs or permits for the transfer of goods through their provinces were abolished.

In 1882, when Turkey placed an internal revenue tax on imported alcohol with the object of making the tax on the foreign product equal to the tax on the native product, the American government regarded the proceeding as clearly contrary to the engagements of the treaties. ${ }^{1}$ At the same time the government of Turkey, having granted a warehouse monopoly which controlled the storage of petroleum and made excessive charges therefor, the United

For. Rel. 1883, p. 819, 832; see also 1882, p. 491, 497, 499, 504, 507. 
States denicd the right of Turkey to set up this warehouse monopoly and declared that Turkey was liable to refund the dues collected under it. ${ }^{1}$

Exemptions of mission schools erom import dutles

Turkish real estate taxes

Turkish $\operatorname{tax}$ on absentee

Under the exemptions from customs dues granted in the capitulations to foreign religious societies in Turkey, the American missionary schools, hospitals and other benevolent institutions have been very largely free from payment of duties upon materials imported for their use. For some years previous to 1888 there were increasing restrictions placed upon this privilege, and in that year at the suggestion of the American minister, Mr. Straus, the foreign embassies at Constantinople called the attention of the Porte to the desirability of continuing the franchise upon a certain amount for each institution annually. ${ }^{2}$

In 1878 foreigners holding real estate in Turkey were required to pay two years' taxes in advance, with the distinct understanding that account should be kept of the sums so paid and that they should be credited on the taxlists of those years. This agreement on the part of the government was not kept and the taxes had to be paid over again. A second requirement of this kind was made in 1881. 'The American minister having requested special instructions, the Department of State authorized him to join with the representatives of other powers in a protest against the measure. ${ }^{3}$

Complaints were made in 1885 that taxes upon schools were imposed by both the imperial and the local governments, but the United States took the riew that, if such taxes were uniform, they could not be regarded as unfair."

A naturalized citizen of Armenian origin, residing in Boston, complained that in his absence from Turkey his relatives were being compelled to pay the personal taxes which would have been imposed upon himself had he re-

${ }^{1}$ For. Rel. 1883 , p. 880 ; see also 1882, p. 509, 520; 1883, p. 822, 829, $834,842,849,874,877,878,887$.

For. Rel. 1888, pt. 2, p. 1562, 1568.

For. Rel. 1881, p. 1176, 1183.

- For. Rel. 1885, p. 872, 878. 
mained in Turkey. Representation was made by the United States against the exaction, and the Turkish government relieved him from further taxation. ${ }^{1}$

In 1853, when the walled city of Shanghai, south of the foreign settlements, was captured by the Taiping rebels, the Chinese imperial authorities requested the consuls of Great The Chinese Imperial Maritime Britain, France and the United States to superintend the collection of customs at that port. The plan proved so satisfactory that under the treaties of 1858 it was extended to all of the open ports. The office of Inspector-General of Maritime Customs was then created, and since 1862 it has been administered with great ability by Sir Robert Hart. ${ }^{2}$ A large number of men in the service are foreigners. There has always been a separate native customs administration under sole Chinese control for the collection of duties payable upon goods carried in native junks. ${ }^{3}$

By the rules agreed upon between Great Britain and China on May $31,1868,{ }^{4}$ and adhered to by other governments, controversies arising in the collection of customs dues on foreign goods were to be investigated by an official of the customs service and the consul of the nationality of the importer of the goods. If these two officials conld not agree upon a decision, they were to refer it to their higher authorities in Peking.

The rules of 1868 appear to have bcen in part modified by those agreed upon on September 6, 1902, by the representatives of China and the treaty powers. ${ }^{5}$ Under the rules of 1902, disputes arising as to the valuation or classification of goods, which may not have been sold when the

1 For. Rel. 1885, p 848, 854, 855, 860 .

2 A report by the American minister upon the administration of the imperial maritime customs service and mentloning the honors bestowed upon Sir Robert Hart by the British and Chinese governments Is glven in For. Rel. 1893, p. 235.

3 The British and American treaties of 1902-3 provide that members of the imperial maritime customs staff shall be appointed to have general supervision of the native custons in each province.

4 Mayers, Chinese Treaties, Shanghai, 1897, p. 230; see also Dipl. Corr. 1868 , pt. 1, p. 521, 571; and infra, Appendix $V-1$.

${ }^{5}$ For. Rel. 1903, p. 117; see also Appendlx V-2. 
application to pay duties is made, are to be referred to a board of arbitration composed of three members, namely, an official of the customs, a merchant selected by the consul of the importer and a merchant of different nationality from that of the importer selected by the senior consul. Questions regarding procedure are to be decided by a majority of the board. If the undervaluation is less than seven and a half per cent., the expenses of the arbitration are to be paid by the customs authorities; if more, by the importer; and if the undervaluation exceeds by twenty per cent. or upwards the amount asserted by the importer to be due, an additional duty of four times the amount sought to be evaded may be exacted.

Liabilities under the treaties of 1858 and 1903

The Inland $\operatorname{tax}$, likin

When the infraction of customs regulations is punishable by fine, the imposition of the fine is within the sole authority of the consular court of the accused, but more serious offenses, such as trading in prohibited articles or smuggling, are punishable by the Chinese gorernment to the extent of confiscating the goods, or the ship, or both. ${ }^{1}$

On the other hand, if illegal action on the part of the native customs service is complained of by a citizen of the United States, it is to be investigated by an officer of the Chinese government of sufficiently high rank, in conjunction with an American officer and an officer of the Imperial Maritime Customs, each of sufficient standing; and if the complaint is well founded and loss has been incurred, due compensation is to be paid. The high provincial officials are held responsible for the punishment and removal of the officer guilty of the illegal action. If the complaint is shown to be frivolous or malicious, the complainant is to be held responsible for the expenses of the investigation. ${ }^{2}$

For many years the most burdensome tax upon native and foreign trade in China was an internal tax called likin, which was collected along the trade routes in the interior. It was nominally a specific tax, but, being farmed out in the

${ }^{1}$ Articles XIV, XXI, Treaty of June 18, 1858; Mayers, Chinese Treaties, ed. 1897, p. $\delta 8,90$.

2 Article IV, Treaty of October 8, 1903; For. Rel. 1903, p. 91-4. 
various provinces, it became so irregular and excessive as to be almost prohibitory of trade. For instance, in 1885, imported kerosene oil, paying a duty of five cents a case, was taxed forty-two and a half cents likin dues in the city of Canton alone, and when taken into the interior, was taxed likin at every successive barrier. Upon the normal annual importation of 500,000 cases the likin collector at Canton alone received approximately $\$ 212,000$, though he remitted to the central government only $\$ 31,000$ in payment for the privilege of farming the tax. The provincial authorities were very averse to any reduction or improved regulation of likin. The central government had granted for foreign goods, whether imports or exports, exemption from inland taxation upon the payment of a transit duty not to exceed fifty per cent. of the export or import duty, and goods upon which the transit duty had been paid were to be protected by what was known as a transit pass. But in practice the transit pass did not protect goods from the inland taxes, and the Chinese government, for its part, justly complained that unscrupulous foreigners allowed the Chinese to use their transit pass privileges to evade the taxes. The difficulties over the likin were a never-ending subject of diplomatic negotiation at Peking.

In the British, Japanese and American treaties of 1902-3 with China it is provided that the levying of likin and all other transit dues shall be abandoned, and that in place of all such imposts foreign imported goods shall pay a surtax in addition to the customs duties amounting to one and onehalf times those duties, and that native produce consigned for export shall pay a surtax which, together with the export duty, shall not amount to more than seven and one-half per cent. ad salorcm. When these stipnlations shall have been accepted by the powers having treaties with China, a date is to be agreed upon when they are to take effect and an imperial edict is to be issued setting forth the abolition of likin taxation, transit dues and all other internal taxation on foreign goods, establishing the surtax system, and enjoining upon all provincial officials the strict observance of

Abolltion of the llkin 
these provisions of the treaties at the peril of severe punishment and removal from office.

Tax on manufactures by for-

nigners

It was provided by the treaty of April 17, 1895, between China and Japan, that Japanese subjects should be permitted to engage freely in manufactures in the open ports of China and that the products of such manufactures should be upon the same footing and enjoy the same privileges and exemptions as merchandise imported into China. Although Japan, by the treaty of July 21, 1896, surrendered the privilege of its subjects of exemption from taxation on articles manufactured in China, the foreign owners of cotton mills at Shanghai claimed a similar exemption under the most-favored-nation clause, holding that their mills had been established before the annulment of the concession to Japan. But the American government declined to support this claim. ${ }^{1}$ The treaty of 1903 between the United States and China provides, in its sixth article, that all products of a foreign type manufactured by foreigners in China with the use of machinery shall be taxed equally with the same class of manufactured products similarly made by Chinese, but that there shall be certain rebates of duties paid on imported materials used in the manufactured articles, and freedom from export duty, coast-trade duty and export surtax.

\section{VII - COMMERCIAL PRIVILEGES}

Privi-

The later treaties with oriental countries, when compared with the earlier, are found to contain much ampler provisions than the latter as to the rights and obligations of foreigners in the exercise of purely commercial privileges. For example, the recent treaties with China, in addition to their long and explicit provisions relating to the maritime rustoms, stipulate that measures shall be taken to protect trade-marks, patents and copyrights, to improve the national 
system of coinage, to revise the mining regulations, to remove obstructions to shipping from the harbor of Canton and to facilitate navigation of the Yangtse River and other inland waters. While no single treaty with Turkey discloses the extent to which Turkish law relating to commerce has been revised under the urgent influence of foreign powers, it is well known that one of the principal results of the war of 1854-6 was the codification of Turkish law, including the making of a code of commerce after the model of the French code; and while no facts of European history of the past fifty years are more conspicuous than the continuous insistence of the powers upon political reforms in Turkey, the diplomatic correspondence shows an almost equal insistence upon administrative reforms protective of foreign commercial interests in that country. In commercial legislation China is still only at the beginning; but in view of the readiness of European and American capitalists to engage in the development of the natural resources, the manufactures and the internal trade of China, so far as they may be assured of adequate protection in their operations, the necessity and advantage of expanding and improving Chinese commercial law is evident. ${ }^{1}$

Until very recently the only action which appears to have been taken by the government of China, in addition to the stipulations of the treaties, for the control of commercial and industrial enterprises in which foreigners were perChinese legislation in the form of regumitted to participate, was in the regulation of the maritime customs, of pilotage, of the navigation of the Yangtse River, and of the inland freight traffic. In 1898, the rules of 1862 as to the navigation of the Yangtse River were revised, rules

${ }^{1}$ An exceedingy valuable report upon "Commercial China," descrlbing the methods and conditions of commerce in China, was prepared in the Bureau of Statistics, Department of Commerce and Labor, and published in the Monthly Summary of Commerce and Finance of the United States, January, 1904, Ho. Doc. 15, pt. 7, 58th Cong., 2d Sess.

Excellent brief reports upon commercial conditions in Turkey are found in Commercial Relations of the United States, 1895-6, vol. II, p. 501 ; 1901, vol. II, p. 758 ; 1902 , vol. II, p. 752 . For a map of the proposed railroad from Central Asia Minor to the Persian Gulf, see Consular Reports, 1899 , No. 235. 
for the navigation of other inland waters were established, and regulations were also promulgated under which foreign capital might be used with Chinese in railway and mining enterprises. In 1899 the Chinese legation in Washington communicated to the Department of State a translation of a dispatch from the Tsung-li Yamên at Peking, prescribing the course necessary to be taken by foreign capitalists in loaning money to subjects of China for the prosecution of commercial enterprises. These later regulations have a eloser resemblance to acts of legislation than the earlier, but the meagerness of their prorisions as compared with the legislation of western states upon similar matters indicates the present insufficiency of commercial law in China.

Jointstock companles

The treaty of September 5, 1902, between Great Britain and China, Article IV, referring to the fact that, although questions have arisen concerning the right of Chinese subjects to invest money in non-Chinese enterprises and companies, large sums of Chinese capital have been so invested, stipulates that China shall recognize the legality of all such investments, past, present and future; that Chinese subjects, who have or may become shareholders in any British jointstock company, shall be held to have accepted the charter of incorporation, or memorandum and articles of association, as well as the regulations framed thereunder as interpreted by British courts, and that the Chinese courts shall enforce compliance therewith if a suit to that effect be entered, provided always that the liability of the Chinese shall not be other or greater than that of British shareholders in the same company. The provisions of this article are made reciprocal. They are not to apply to cases which have already been before the courts and have been dismissed.

Rights of For some twenty years before the treaty of 1895 , between manuing in ing in China and Japan, the question of the right of foreigners to engage in manufactures in China was much discussed. The Chinese government contended that the treaties had granted only the right to employ Chinese workmen at small pieces of work and without machinery. ${ }^{1}$ But the treaty with

${ }^{1}$ For Rel. 1882, p. 117, 134. 
Japan, as we have already seen, freely granted the right to import machinery and use it in manufactures at the treatyports. In connection with these new privileges the Japanese treaty and the treaties of $190 \%-3$ do not stipulate any additional rules of jurisdiction, yet, inasmuch as the new privileges are inducing foreigners to undertake enterprises of all kinds and extensively increasing their business relations with the Chinese and with other forcigners, it is beyond doubt that the activity of the consular courts and the Chinese courts will be largely increased.

In the several railway and mining concessions which the Chinese government has granted, as well as in the contracts into which it has entered in recent years, the methods of financing these enterprises, of acquiring rights of way, acquiring lands and materials of construction, and of organizing the management, are expressly defined. China undertakes to protect the foreign as well as the native capital invested, and at the same time reserves control of the enterprises. The position of the Chinese government in these concessions and contracts is so important that any controversy as to the main points wonld no doubt be reserved for diplomatic negotiation, whereas the settlement of minor difficulties would, with equal reason, be left to the methods established by the existing treaties. The Chinese government exercises authority in the construction and operation of the railways and mines through a bureau of control established by imperial edict. ${ }^{1}$ The foreigners engaged in the railway service may be assumed to have a standing analagous to that of foreigners in the Imperial Maritime Customs, that is, to be subject to the orders of a directorgeneral of railways, being dismissed from the service in case of criminal offense, and being subject to indictment in the courts of their respective eonsuls. ${ }^{2}$

There appears to have been no specific definition of the attitude of the United States toward these large financial

\footnotetext{
${ }^{1}$ Rockhill, Treaties Relating to China and Korea, p. 249.

${ }^{2}$ Supra, p. 86.
} 
Non-political interest of the

United

States in

commer-

clal pro-

jects
Effect of the "open door' policy
Monopolles in China

undertakings of its citizens in which they have become parties to contracts with the government of China. The Chinese government desired that its railway concessions should be taken by companies of different nationalities, and the already existing 'spheres of influence' of the various European powers determined to a large extent how the cuncessions should be apportioned. In granting to an American company the concession for the Hankow-Canton railway, which is the main line through central China, the imperial authorities no doubt took into consideration the long-standing policy of the United States, under which it has desired for its own citizens no general commercial privileges of an exclusive character. American citizens desirous of obtaining concessions have received the support of their ministers and consuls, but not to such an extent as to invest their enterprises with a political significance. ${ }^{1}$

The 'open door' commercial policy has a profound effect upon extraterritorial rights in China, in that it maintains a general uniformity of commercial rights of foreigners throughout the empire, whereas the adverse policy of demanding special commercial privileges would greatly increase the difficulties of administering justice in consular courts.

Consistently with this policy, the United States has opposed the granting of any monopoly to a foriegn country or corporation that would exclude American citizens from entering the same form of enterprise on equal terms and with fair competition. In 1881, when an agreement was drafted by which the Chinese government was to concede to the Danish Great Northern Telegraph Company the exclusive right to construct overland telegraph lines from the Siberian frontier and throughout China as well as to lay submarine cables touching the coasts of China, the United States protested against the proposed concession as being inharmonions with the equal commercial rights of its citizens

1 For. Rel. $189 \%$, p. 56. This concession reverted to the Chinese government by sale in 1905 . 
under the treaties, and the concession was radically modified and limited. ${ }^{1}$

The granting of private monopolies of warehouses for the compulsory storage of petroleum in Turkey, in 1882 and Monopolies in Turkey 1889, was regarded by the governments of the United States and of Russia as a virtual doubling of the import duty agreed upon in the treaties of $1861-2$, and upon this protest the warehouse concession was revoked. ${ }^{2}$

In 1887 the Turkish government issued a regulation forbidding agencies of foreign joint-stock companies to do business in the Ottoman dominions without having previously obtained a Turkish permit. The foreign ministers at Constantinople, holding that this regulation constituted an encroachment on the liberty of commerce guaranteed by the treaties, informed the Porte that they could not assist in the enforcement of it. ${ }^{3}$ The Turkish government, however, does not appear to have modified the regulation. In 1901, the New York Life Insurance Company, even though it had fully complied with the regulations, was placed with other foreign life insurance companies under such additional restrictions as almost to prohibit it from doing business in Turkey. The principal restrictions were that its agents were prevented from travelling in the interior and its communications through the Turkish mails interfered with. It appears that there were special difficulties caused by the efforts of the central government to prevent native agents of the companies from using their business connections for spreading revolutionary ideas. ${ }^{4}$

There have been numerous instances of governmental interference with the mails addressed to foreigners in TurPostal privikey. In 1893 Turkish officials claimed the right to open letters and examine them at any time when there was disturbance in the locality to which or from which they were sent. The Department of State expressed earnest solicitude

1 For. Rel. 1881, p. 317; 1882, p. 115.

For. Rel. 1889 , p. 710 ; see also 1883 , p. 880 ; 1884, p. 557, 562.

${ }^{3}$ For. Rel. 1888, pt. 2, p. 1592.

- For. Rel. 1902, p. 1026. 
that the personal rights of American citizens in regard to their private correspondence should be respected. ${ }^{\mathbf{1}}$ There is an extensive international postal service in Turkey, independent of the native service.

Several treaty powers maintain their own postal service in the open ports of China. The United States has not done so, because it has regarded the postal service maintained by China under direction of the Imperial Maritime Customs as satisfactory and has desired to encourage the extension of this system. ${ }^{2}$

Collectlon of debts

In connection with the collection of debts through actions at law in consular or native courts, it is usually stipulated that neither government shall be held responsible for the debts or the fraudulent acts of its citizens or subjects. ${ }^{3}$ The United States statutes make no special provision for actions for the recovery of debts, but the consular court regulations for Turkey and for China contain provisions under which process of attachment of an American defendant's property or of arrest of his person may be issued, as well as other provisions for obtaining redress against debtors. ${ }^{*}$ The American consul-general at Constantinople, Mr. C. M. Dickinson, reported in 1898 that there was very little difficulty in collecting debts in Turkey; "nearly all the merchants in Turkey," said he, "are Greeks, Italians, English, Germans, Austrians, and French," and "a resort to the Turkish courts is scarcely ever necessary." " The law of bankruptcy under American foreign jurisdiction is wholly undeveloped, and it appears also to have been but little developed under the British system. ${ }^{6}$

In 1893 the government of Persia complained that foreigners had accepted claims due from one Persian subject

${ }^{1}$ For. Rel. 1893, p. 597, 623.

For. Rel. 1902, p. 222, 225.

${ }^{3}$ United States and China, July 3, 1844, Article XVI; June 18, 1858, Article XXIV; Capitulations of 1740, Articles 22, 23, 53, 66, 69.

'Sen. Misc. Doc. 89, p. 70, 103, (vol. 1) 47th Cong., 1st Sess.

- Commercial Relations of the United States, 1898, vol. II, p. 605.

- Piggott, Exterritoriality, p. 125-32; Hall, Foreign Jurisdiction, p. $186-8$. 
to another in payment of debts due to themselves, and were seeking the aid of their legations to collect such claims. The practice does not appear to have been resorted to by AmeriAssign. ment of claims to Poreigncans, but when the Persian Foreign Office sent a circular note to the forcign powers stating that such transfers of claims would be considered void, unless made under the seal of Persia and legalized in the legation, the American minister was instructed that the United States "will never recognize an assignment of a claim against a foreign country made by a citizen or subject of that country to a citizen of this for the purpose of involing diplonatic aid in the recurery thereof. Still less will it undertake to aid in the recovery of claims against subjects of foreign countries which originally accrued in favor of their fellow-subjects and have been assigned by the latter to American citizens." ${ }^{1}$

The heavy indebtedness of both Turkey and China in proportion to their taxable resources has been very largely inFinancurred through the difficulties those governments have experienced in maintaining order within their boundaries, in protecting foreigners and foreign commerce, and in developing a generally efficient internal administration. The fact that these enormous debts have come intu existence gives very tangible evidence of the original necessity of establishing extraterritorial privileges in those comntries, and it is probable that so long as they remain burdened with extraordinary debts they will continue to be regarded as unprepared for the relinquishment of extraterritoriality. The condition of government finances of course indicates the strength or weakness of the general administration, and in China and Turkey it indicates the greater or less degree to which other powers have been and are obliged to secure special protection for their citizens or subjects and their commerce in those countries.

Nearly all of the claims which have been preferred by claims American citizens against oriental governments have arisen oriental out of injuries caused to person or property through failure 
to give the protection guaranteed by the treaties. ${ }^{1}$ It would be obviously impossible under conditions which still exist in those countries to obtain redress through ordinary legal actions in the native courts. ${ }^{2}$ Minor difficulties, it is true, have been occasionally settled by the local authorities, ${ }^{3}$ but the claims arising from serious outbreaks of violence have necessarily been taken up by the diplomatic representatives of the United States and the oriental governments concerned. ${ }^{4}$ The validity of the claims has then been usually determined in the executive departments of the two governments.

Clalms agalnst China

A number of claims against China, including some that arose out of the war between China and Great Britain, which began in 1856, were made the subject of an indemnity convention, November 8, 1858. The United States appointed a special commission to decide upon the merits of the claims, and about two-thirds of the total amount of the indemnity was awarded to claimants. In 1885 the remainder, amounting with interest to $\$ 453,400.90$, was turned over to the Chinese minister at Washington. ${ }^{5}$

The claims against China, growing out of the anti-foreign uprisings of 1900 , embraced the losses suffered by the several foreign governments by reason of the attack on the legations in Peking, as well as the expenses of the expeditions sent out for the relief of the legations and the protection of

${ }^{1}$ The claim of Dr. M. A. Cheek against the King of Siam was contractual; it was settled by arbitration; infra, p. 162 . Another contractual claim was that of the "Ward estate" against China; it was arbitrated, but the award appears not to have been paid; For. Rel. 1888, pt. 1, p. 199-218.

2 Although the United States has not admitted that redress for injuries br mob violence within its borders might be obtained in any other way than through the courts, it has, out of clemency, paid indemnities for such injuries in certain cases in which it would have been practically impossible to obtain justice in the courts on account of local prejudice; For. Rel. 1887, p. 169; see also For. Rel. 1886, p. 101-56.

For. Rel. 18i1, p. 75; see also For. Rel. 1890, p. 147; 1891, p. 354.

- The American diplomatic representatives are directed, except in certain extraordinary cases, to seek instructions from the Department of state before presenting any claim for collection; For. Rel. 1896 , p. 46.

For. Rel. 1885, p. $182 ; 1886$, p. 140. 
foreigners. The claims of individuals for personal injuries and losses of property were not itemized in the negotiations, but were left to be settled by the varions foreign governments out of their respective shares of the lump sum of $\$ 333,000,000$, which China agreed to pay. The United States considered this enormons sum to be far in excess of what was justly due, but agreed to it, rather than prolong the occupation of Chinese territory by the expeditionary forces and thus cause the claims to increase indefinitely.

The attitude of the United States in entering upon concurrent action with the other powers had been defined in the circular telegram of the Secretary of State, John Hay, July The "opendoor" policy 3,1900 , which read in part as follows:

We adhere to the policy initiated by us in 1857 of peace with the Chinese nation, of furtherance of lawful commerce, and of protection of lives and property of our citizens by all means guaranteed under extraterritorial treaty rights and by the law of nations. . . . The policy of the Government of the United States is to seek a solution which may bring about permanent safety and peace to China, preserve Chinese territorial and administrative entity, protect all rights guaranteed to friendly powers by treaty and international law, and safeguard for the world the principle of equal and impartial trade with all parts of the Chinese Empire. 1

The successful carrying out of this policy by the American commissioner and plenipotentiary, Mr. W. W. Rockhill, in the long and difficult negotiations at Peking, has proved that it commended itself to the other powers interested and, while adequately securing reparation for wrongs done to American citizens and guaranties for their future protection, has confirmed the long-standing friendship of the United States and China. ${ }^{2}$

1 For. Rel. 1901, Appendix, p. 12.

2 The correspondence fllustrates in much continuity of detail the successlve steps by which the negotiations were consummated; For. Rel. 1901, Appendix. 
At the time of the Armenian disturbances in Turkey in 1895, much $\Lambda$ merican property was destroyed. The claims for indeninity were at first resisted by the Porte on the ground that a government could not be heid liable for losses occasioned by insurrections and that the local authorities had taken all the measures within their power for the protection of the lives and property of Americans. The United States produced evidence to show the negligence and connivance of Turkish officials, and renewed its claims. ${ }^{1}$ There were also claims arising out of the same disturbances preferred by France, Italy and Great Britain, and these claims, like the American, were held by the Turkish government not to be well grounded. No suggestion of joint action among the powers in pressing these claims appears to have been made. In 1898 the American minister, Mr. Straus, drew up a memorandum of the circumstances under which the United States itself had granted indemnities and by oral presentation of the subject to the Turkish Minister of Foreign Affairs, obtained his recommendation to the Council of Ministers that the claims be paid. During an audience with the Sultan, December 9, 1898, Mr. Straus was informed by His Imperial Majesty that he had directed the settlement of the claims. The principle of the American demand was thus admitted by the promise to pay which the Sultan then made and subsequently repeated at various times. The delay in actual payment is assumed to have been caused only by the deplorable state of the finances of the empire. ${ }^{2}$

Only a few years before, the Turkish government had paid indemnities for the destruction of American property under circumstances not unlike those of 1895 . The earlier claims were far less in amount, but the principles of liability were apparently the same. ${ }^{3}$

1 For. Rel. 1896, p. 892, 897; also supra, p. 116-7.

2 For. Rel. 1899, p. 765, 768.

- For. Rel. 1892, p. 583, 593, 594; 1893, p. 631. 
THE INTERNATIONAL TRIBUNALS OF EGYPT; MIXED CASES IN CHINA
\end{abstract}

When the parties to an action in a consular court are of different nationalities it is usual to sue in the court of the defendant's consul, but, unless the case be simple, this method may prove unsatisfactory. There long existed in Turkey a usage sanctioned, it is be- Modificalieved, by an exchange of notes by the foreign ministers in 1820 , which permitted that, in cases involving only foreign- in tey ers, a mixed commission should be set up for each case as it arose, and should consist of two judges chosen by the legation of the defendant's nationality and one by that of the plaintiff; but in 1864 the French court of appeal at Aix declared a commission so organized to have no lawful jurisdiction over Frenchmen. ${ }^{1}$ Since then the old rule of actor sequitur formm rci has prevailed, and sanction was impliedly given to it in a British Order in Council of December 12, $18 \% 3 .^{2}$

Over controversies in which a Turkish subject appears either as plaintiff or as defendant, the Turkish government

' Sirey 65, 2, 291, Pigeon v. Issaverdens et Cie., November 28, 1864.

An Order in Council of January 23, 1863, Art. 218-37, not printed in the State Papers, is said to have sanctioned this form of jurisdiction in cases brought against British subjects; see Féraud-Giraud, Juridiction française, vol. 2, p. 255; see also Brit. and For. State Papers, vol. 50, p. 676, Art. LXIII-V; see also Salem, Les étrangers devant les tribunaux consulaires et nationaux en Turquie; Jour. du droit internat. privé, 1891, p. 414.

2 Brit. and For. State Papers, vol. 63, p. 78. Sec. 81-5.

The United States Consular Regulations of 1896, Par. 620, state that a usage is believed to exist under which 'foreign Christians' are tried before 'mixed tribunals.' This statement appears to refer to

The rule of defendant's court the ruie tried before 'mixed tribunals.' This statement. 
Jurisdiction of Turkish subjects reserved

The mixed tribunal of commerce

reserves jurisdiction. Its jurisdiction is not, however, unrestricted: the judge cannot hear the complaint unless the contract be in writing and sealed by a notary public; and neither can the trial proceed nor judgment be pronounced unless the consular dragoman be present. The provision of the capitulations corresponding to the provision in the American treaty of 1830 , that mixed cases of a value of five hundred piastres or more involving Turkish subjects should be submitted to the Sublime Porte, has fallen into desuetude, although, if occasion demanded, it could probably be used to support a claim of right to bring a case out of the jurisdiction of a lower or provincial court into one within the immediate control of the Porte. It has often occurred that a Turkish plaintiff, knowing that the execution of a judgment belongs solely to the consul of the alien defendant, has taken his claim without trial directly to the consul, thus practically following the rule of suing in the defendant's court and unconsciously tending to revive the long forgotten assumption that consuls could be held responsible for the acts of their nationals. ${ }^{1}$

The Turkish government, in its desire to abridge in every possible way the jurisdiction of consuls, has done much to assimilate principles of commercial law from the law existing in western Europe, and, under the rights of jurisdiction reserved to itself in the capitulations, it provided in a decree issued in 1849 and modified by a second decree in 1860, a special court, the tidjaret, ${ }^{2}$ usually spoken of as "the mixed

the usage above mentioned as prevailing from 1820 to 1864 . According to Mr. Salem, who has long practiced law at Salonica, the principle of suing in the court of the defendant's consul has been in force since 1864; Les étrangers devant les tribunaux consulaires et nationaux en Turquie, Jour. du drolt, internat. privé, 1891, p. 413-25.

For a summary of the provisions made by the various powers for the trial of mixed cases in Turkey, see Salem, Tribunaux consulaires et nationaux en Turquie, Jour. du droit internat. privé, 1891, p. 393, 413-25.

See also a memoire of the Sublime Porte published July 7, 1869, addressed to the foreign legations and to the provincial authorities; Aristarchi, Législation Ottomane, vol. 2, p. 421.

1 Salem, Les étrangers devant les tribunaux consulaires et nationaux en Turquie, Jour. du droit internat. privé, 1891, p. 801-9.

${ }^{2}$ The full name of the court is Mehkemet Tidjaret Muhtelit Medjlissi. 
tribunal of commerce,' for the trial of civil and commercial cases. In this court the foreigner is entitled to the attendance of two assessors or juges temporaires of his own nationality to sit upon the bench with three Turkish judges or juges perpetucls, one of whom presides. ${ }^{1}$ This organization of the court does not preclude the foreigner from his right to the presence of his consular dragoman. The competence of the court extends to cases of a value exceeding one thousand piastres. Cases of a lower value are heard in civil tribunals composed of a presiding judge, chosen by the government, and two assessors. In localities nine or more hours distant from a consulate cases of a value less than one thousand piastres are heard by the civil tribunals without the presence of the consular dragoman, but with the reservation of the right of appeal to the court of the arrondissement, where the assistance of the dragoman is required. From the civil tribunals and the mixed tribunals of commerce in cases the value of which exceeds five thousand piastres, appeal lies to the first chamber of the mixed tribunal of commerce at Constantinople or, if a maritime case, to the maritime chamber of this tribunal, and the decisions of these courts are final.

The law administered in these Turkish courts is that of the code of commerce of 1850 with its appendix of 1860 , the code of commercial procedure of 1862 , the maritime code of 1864, and the civil code of 1869 . The code of civil procedure of 1879 has not, it is believed, been accepted by the foreign legations at Constantinople as applicable to the trial of mixed cases. ${ }^{2}$

It was in Egypt, about the time of completing the Suez The Canal, that the difficulties of jurisdiction in mixed cases first evorts

\footnotetext{
${ }^{1}$ Gatteschi, Diritto pubblico e privato ottomano, p. 341. Salem, Les étrangers devant les tribunaux consulaires et nationaux en Turquie, Jour. du droit internat. privé, 1891, p. 795. 797. Young, G., Second secretary of the British Embassy at Constantinople, Corps de Droit Ottoman, London, 1905, 7 vols.

2 There appear's to have been no continuous publication of reports of cases tried in the consular courts of any nationality in Turkey. Many notes upon important cases are given in the Journal du droit international prive, and references are there made to Turkish publications.
}

Appeals

to courts in Connople

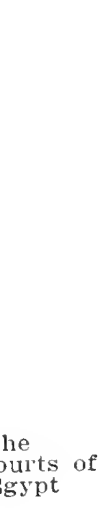


became so serious as to require the special consideration of the western powers. The cities of Alexandria and Cairo were extremely cosmopolitan. Traders and travelers from all nations came to this gateway between the continents, and Egypt was thought of as more European than Turkish. In 1875 the number of consular courts in Egypt, each privileged to exercise jurisdiction according to its own national law, was no less than seventeen, yet only three or four of the powers most interested had made adequate prorision for the administration of this jurisdiction, and the mixed cases, including those to which the government of Egypt was a party, besides being exceedingly complex, long unadjudicated and very expensive, had sometimes resulted in conspicuous failures of justice.

History of establishing the inter national tribunals

The Sultan of Turkey had recognized in certain firmans of 1841 and 1866 that his relation to the Khedive of Egypt was only that of a suzerain to whom annual tribute was due and in whom there rested no authority to regulate the internal affairs of Egypt. To these arrangements the principal governments of Europe had given their sanction, and they had raised the office of their chief representatives in Egypt to the special grade of diplomatic agent and consul-general. ${ }^{1}$

But the hopeless indebtedness of the Khedive's government was fast rendering the actual intervention of the powers in one form or another unavoidable. Most of the debt was held in France, and French capital was invested throughout the country. An able Egyptian official, Nubar Pasha, had moved the French government to consider the advantages of reforming the judicial system and of bringing about closer coöperation between the consular courts; but the Franco-Prussian war of $18 \% 0-1$ had put an end to this movement.

In 1873 , at the instance of Germany, an international commission assembled in Constantinople and prepared a project for establishing mixed courts in Egypt. At the same time the Sultan admitted the power of his viceroy, the

\footnotetext{
${ }^{1}$ Edward Dicey, Story of the Khedivate, London, 1902.
} 
Khedive, to conclude treaties of commerce and treaties relating to the internal administration of the country. The governments of the foreign nations more closely related to Egypt-that is the French, Italian and Greek, whose combined interests represented, if we except the British traffic through the canal, much the larger part of the invested foreign capital and of the foreign population as well-were reluctant to enter upon an agreement which would give other European powers a foothold for future interference in the affairs of Egypt. Yet the influence of the other powers preponderated, and with special reservations as to bankruptcy cases insisted upon by France in the interests of French creditors, the modified project of Nubar Pasha was adopted. ${ }^{1}$

The European governments declared their acceptance of the plan by signing special conventions with Egypt; ${ }^{2}$ the United States, by a proclamation of the President authorized by Act of Congress. ${ }^{3}$

The actual opening of the tribunals occurred on February 15, 1876. From $18 \% 6$ to 1890 alone, the courts were occuActivity of the
sourts pied with the hearing of 47,428 causes and they rendered 34,086 decisions. ${ }^{4}$ The excellence of their administration has been deservedly praised. It has at no time been justly charged that they were acting either as mere functionaries of the Egyptian government or that they were submitting to the foreign influence predominating in Egyptian affairs. The nine foreign judges, who, with the four native judges, composed the court of appeal at Alexandria in 1896, were chosen as follows: One judge each by the governments of Great Britain, the United States of America, Germany, Austria-Hungary, Greece, Italy and Russia, and two judges by the government of France.

\footnotetext{
${ }^{3}$ Féraud-Giraud, Les institutions judiciaires en Egypte; Rev. de droit internat., 1890, p. 70; a bibliography is appended.

Brit. and For. State Papers, vol. 66, p. 106.

- Act of March 23, 1874, 18 Stat. at Large, 23. The proclamation was dated May 27, 1876, 19 Stat. at Large, Proclamations, p. iv; it is also found in For. Rel. 1876, p. 1.

- Féraud-Giraud, loc. cit., p. 73.
} 
Analysis of the Règlement d'organi sation judiclaire

The jurisdiction of the international tribunals extends in general to civil and commercial cases between aliens and natives, including officials of the Egyptian government, and between aliens of different nationalities; questions of personal status, matrimonial causes and inheritance belong as formerly to the consular courts, yet jurisdiction in these matters has tended to widen because the excellent administration of the tribunals has led to the submission to them of whatever could be claimed to be within their power. In 1900 France withdrew her reservation as to bankruptcy cases. The courts have a limited criminal jurisdiction, intended in the first place solely for their own protection, but extended in 1889 by decree of the Khedive so as to apply to all general police regulations for the public security not including offenses of a serious nature. ${ }^{1}$ The law administered in these tribunals is that of the Egyptian codes, which are modelled upon the French. The official languages are Arabic, Italian and French. There are three courts of first instance, each originally composed of seven judges, four aliens and three natives, and a court of appeals at Alexandria, similarly composed. The number of judges has since been increased. The judges are nominated each by a foreign government represented in the tribunals, and upon such nomination the Khedive makes the appointment. They hold office five years and, though answerable upon charges before the court of appeals with liability to loss of salary, hold office during the quinquennial period. They may not receive any emolument beyond their stipulated salaries or accept any office or honor from the Egyptian or any other government. The execution of sentences is accomplished throngh officers of the courts with the aid of the Egyptian authorities, if necessary; yet the consul of the foreigner interested in the judgment must be notified and may be present, if he desires, when the execution is effected.'

${ }^{1}$ Brit. and For. State Papers, vol. 81, p. 578.

2 The text of the Reglement is to be found in Brit. and For. State Papers, vol. 66, p. 583. 
Soon after the courts were established decisions were rendered against the Egyptian government and against the Khedive himself, involving large sums of money, but Egypt and the Khedive had long been financially embarrassed and the judgments remained unexecuted. The creditors loudly protested, and in 1878 the court of appeals went so far as to suggest that the powers intervene to compel payment. After a further delay of two years the Khedive's government responded by decreeing that it would pay fifty-five per cent. of the amount of the judgment in coin and the balance in paper. This proposition was obvionsly a violation of the original agreement of Egypt to execute the judgments of the tribunals. Would the powers now intervene? The initiative was again being taken by Germany, when, by the joint action of France and Great Britain, a change in the financial régime of Egypt was nnexpectedly brought about and the debts were refunded. ${ }^{1}$

A second erisis arose in 1896. The Khedive's government, upon the advice of the British diplomatic agent, had deflected the revenues so as to contribute $£ 500,000$ toward the expenses of a military expedition into the Soudan. The Crisis of 1896: control of the calsse de la dette' creditors of Egypt at once brought suit and obtained judgment in the international tribunals to compel the government to preserve its funds intact under the provisions of the international conventions. These conventions, establishing a 'caisse de la dette,' controlled by an international commission, were held to be contracts, which were justiciable under Article XI of the Rieglement, and which, by an administrative act, the Egyptian government had broken. As to the defense that the commission had decided, by a vote of four to two, that this extraordinary expenditure would in the end benefit the creditors, the court held that the minority of the commission could bring suit to prevent this appropriation of moneys since the commissioners were individually responsible to the creditors. How a military expedition, undertaken at extreme risk, could, before it was

Argument of M. Manoury before the National Assembly of France, November 23, 1882; De Clercq, Traités de la France, vol. 14, p. 90. 
initiated, be reyarded as a benefit to the creditors, it was difficult to understand. ${ }^{1}$

Ques.

tion of permanece of the trib. unals

The affair caused irritation in England, and Lord Salisbury expressed an opinion that the time had arrived when the constitution and powers of the mixed courts ought to be reconsidered. Nevertheless in 1899 England, with the other powers, again renewed for a period of five years the convention upon which the authority of the courts rests. The continental governments, jealous of the increase of English influence in Egypt, have looked upon the various international institutions of that country, the tribunals, the commission for liquidation of the debt, the sanitary commission, and the municipality of Alexandria, ${ }^{2}$ as agencies whose success would prevent any one power from gaining domination. Great Britain has professed to be occupying Egypt and to some extent controlling its administration only temporarily and has refrained from assuming a protectorate. In reality, however, the power of Great Britain in Egypt is far greater than that which a protector usually exercises. But since the Anglo-French agreement of 1904, which leaves France a prevailing influence in Morocco and recognizes British predominance in Egypt, it seems probable that at least by 1912, when the conventions expire that give authority to the debt commission, the international tribunals will be reorganized or possibly transformed so as to become an integral part of the Egyptian national system of courts. ${ }^{3}$

\footnotetext{
${ }^{1}$ McIlwraith, The Egyptian Government and the Caisse de la Dette, Jour. Soc. Compar. Legislation, vol. 1, (old series), p. 386; the footnotes contain reports of the cases.

2 The municipality of Alexandria is not justiciable before the international tribunals; amendment to Article IX of the Reglement judiciare, Brit. and For. State Papers, vol. 92, p. 882.

${ }^{3}$ The reports of 1905 and 1906 of Lord Cromer, British Agent and Consul-General in Egypt, propose a Legislative Council for Egypt under international agreement and substitution of Egyptian courts under reservations in place of the present international tribunals; infra, Appendix $\mathrm{x}$.

By decree of the Egyptian government, February 10, 1905, the international tribunals are to be continued for five years from that date.

A system of international tribunals similar to those in Egypt was proposed for Japan in 1886 in place of the outright relinquishment of consular jurisdiction by that government; but the Japanese declined to accept it; infra, p. 185. Rev. Stat., Sec. 4126 refers to jurisdiction of mixed cases In Persia; supra, p. 45.
} 
At the conference of the ministers to China in 1879 the Mixed subject of judicial proceedings in mixed cases was very thor- cases in oughly and ably presented by the American minister, Mr. George F. Seward. From the special reports of consuls, it conference of 1879 was found that in actual practice the settlement of a claim against a Chinese debtor by resorting to a Chinese court was next to impossible. The Chinese law was deficient in remedies; even the presence of foreigners in Chinese courts, whether as parties to the action, witnesses or attorneys, was ordinarily disallowed. In consequence, when a friendly settlement out of court could not be brought about, the consul was almost unavoidably obliged to undertake to prescribe to the Chinese magistrate what judgment to pronounce. Thus, although the treaties required that the decision be made by the judge of the defendant's nationality, a form of mixed court was being developed by usage. In fact there was a tendency on the part of some of the foreign ministers themselves to favor the adoption of a system of mixed courts. The success of the international tribunals in Egypt was held forth as an example of what might be done in China. But the American minister and his British colleague were disinclined toward this proposition for the reason that conditions in China differed so essentially from those in Egypt as to offer no guarantee of success. Egypt was comparatively a small country, foreign interests were well centralized and the nature and methods of European jurisprudence were better known to the officials of the Egyptian government. In China the distances between the open ports were very great, the foreign residents were more widely segregated from the native population; and the governing classes in China had not yet acquainted themselves with western law and judicial practice. A system of mixed courts at that time and for China as a whole was therefore deemed impracticable.

Moreover, Mr. Seward, having in mind the coöperative or, as more recently called, the 'open door' policy initiated by his predecessor, Mr. Burlingame, was persuaded of the Mr. Sew ard's propositions advisability of favoring the development of a national 
system of jurisprudence for China upon western principles of law; and with that ultimate end in view, while proposing that the rule of the treaties requiring trial and judgment by the court of the defendant should be strictly adhered to, he recommended that the conference express a desire to the Tsungli-Yamen to have the following improvements introduced: First, that the Chinese courts be designated in which complaints of foreigners could be heard and determined; second, that the right of the foreigner to appear in these courts in person and with witnesses be secured, and that compulsory process to compel the attendance of native witnesses be allowed; third, that the consul of the complainant be entitled to be present in court to assist in placing the evidence before it; fourth, that records of all the proceedings, evidence, opinions and judgment be kept. An additional memorandum upon the Chinese or so-called mixed court at Shanghai was submitted to the conference. Mr. Seward's entire report was unanimously adopted and a joint note of the ministers communicating their views was sent to the Tsungli-Yamên. In reply the Chinese authorities expressed themselves conserratively, and declined to take immediate steps for the betterment of the Chinese courts.

Existing practice in China Yet in the course of years the lines of improvement suggested in the conference of 1879 have been followed, and the unanimous agreement of the ministers to uphold strictly the rule of the treaties, requiring that in mixed cases a Chinese defendant be tried by a Chinese judge, the foreign consul being restricted to assisting in bringing evidence before the magistrate and having no right to interfere as to his decision in the case, undoubtedly contributed much to the preservation and development of the jurisdiction of China in respect to the claims of foreigners. ${ }^{1}$

Cases be$t$ ween for eigners of differ. ent nationalities cation. The British courts require of an alien plaintiff
As between foreigners of different nationalities in China, the rule of suing in the defendant's court has general applisuing a British defendant that he show the written consent

${ }^{1}$ For. Rel. 1880, p. 140, 143, 145-67, 189, 225-35, 242-8, 249-56, 273; Brit. and For. State Papers, vol. 72, p. 1015-31. 
of his consul, besides giving security for the payment of fees and for performance of the decision of the court. The requirement is obviously fair in that it obliges the foreign plaintiff only to submit himself to the process of the court and nothing more, yet it is of much value to have the defect of lack of jurisdiction over the alien plaintiff thus partially removed. ${ }^{1}$ When a counterclaim against the Japanese government in an action against the Peninsular and Oriental Steamship Company came by appeal before the Privy Council in 1895 it was not entertained. ${ }^{2}$ In the American courts a set-off is allowed to be pleaded against an alien plaintiff in so far as it is a defense. ${ }^{3}$

It has been noted as a distinguishing feature of jurisdiction in mixed cases in China that when one of the parties is a native, contrary to the practice in the Levant, the rule of suing the defendant in the court of his nationality prevails. Turkey claims jurisdiction over all cases involving Turkish subjects; by treaty China has conceded to the foreign consular courts the trial of cases brought by Chinese plaintiffs against defendants who are foreigners. The presence of a Chinese official in such a trial in a consular court is not required by law, although for the sake of better securing execution of the judgment his presence is usually solicited. If a Chinaman is defendant, the case is heard before a Chinese magistrate, but never without the presence of a consular officer of the alien's nationality sitting with the Chinese judge. ${ }^{4}$ Moreover, it frequently happens that an amicable settlement of a dispute between Chinese and foreign merchants is effected without recourse to a formal trial.

It remains to call attention to the fact that occasionally mixed cases, especially criminal cases resulting from antiforeign riots, involve such perplexities or beeome of such importanee to the public policy that they are made the subject of diplomatic correspondence to the extent of demand-

Differences of Jurisdiction in mixed cases in China and in Turkey 
ing special reparation and indemnity from the oriental gorernment. What is thus demanded is much more than the enforcement of the claims of foreign complainants before native tribunals: it is required that the oriental government directly avow its responsibility for the particular outrage. The United States apparently recognized the reciprocal operation of such a rule in granting indemnities to subjects of China for loss of life and property in the anti-Chinese riot at Rock Springs, Wyoming, in 1885; but, in other cases in which similar indemnities have been paid by the United States for injuries inflicted on Chinese, the redress has been expressly declared to be an act of benevolence. ${ }^{1}$ When similar unfortunate outbreaks of violence have occurred in China and Japan, those governments have not delayed in the payment of indemnities. The peculiar necessity of insisting upon payment of indemnities by Turkey for the losses by American citizens during the disturbances of 1894-6 arises from the fact that the Turkish government though forewarned of impending disturbances did not take measures requisite for their prevention.

An exceptional settlement by arbitration

Finally, there has been at least one case involring an oriental government and a foreign claimant which has been subnitted to arbitration. It was the claim of the estate of Dr. M. A. Cheek, an American citizen, against the government of Siam, arbitrated in 1898 . The summary proceedings which had been resorted to by Siam, namely, the confiscation of certain lots of teakwood timber and other property, was claimed to be in violation both of the treaty of 1856 and of Siamese law as well; and it was contended for Dr. Cheek that the consular court of the United States was the proper forum in which to have brought action against him. It was, however, agreed between the parties, the American government being cognizant of the proceedings, to submit the controversy to arbitration. The arbitrator was Sir Nicholas Hannen, Chief Justice of Her Majesty's Supreme Court for China and Japan. ${ }^{2}$

1 Supra, p. 148, footnote 2.

Moore, International Arbitrations, vol. 2, p. 1899-1908; vol. 5, p. 5068. 


\section{VI}

\section{THE FOREIGN MUNICIPALITY AT SHANGHAI}

From 1842 to 1860 the treaties with China restricted the trade and residence of foreigners to the five ports of Canton, Amoy, Foochow, Ningpo and Shanghai. It was not until the treaties of 1858 , which were first actually put into operation Organtzation of foreign communities in at the close of the war of Great Britain and France against China in 1860, that the great river, the Iangtse, and the important seaports north of that river were open to western commerce. Under the treaties of 1858 the privilege of residence at the open ports consisted of a right to rent and build upon land adjacent to the Chinese cities in a district set apart by the local representative of the imperial government in conference with the consul. At the larger commercial centers the number of foreigners increased sufficiently to make some form of municipal organization advisable, though perhaps as great a reason for such municipal organization was that the native Chinese, being permitted to live within the concessions, became so numerous as to make necessary some common regulation and control for the security, order, and cleanliness of the mixed community. The foreign population of China has always been comparatively very small, never exceeding thirty thousand, and though under the American, British and Japanese treaties of 1902-3 more than thirty ports are now open and many foreigners, mostly missionaries, are residing in the interior, the only considerable foreign communities are at the three ports of Canton, Shanghai and Tientsin. ${ }^{1}$

1 The Directory and Chronicle for China, etc., published annually by the Hongkong Daily Press, is a most complete and valuable book 
The Por- The earliest of the foreign settlements in China was that tuguese colony of of Macao. In $155 \%$ the Portuguese were allowed to careen Macao their ships and store their goods in a small harbor at the outer end of a rocky island sonth of the entrance of the river leading to Canton. Sixteen years later, to keep the Portugnese secluded, the Chinese anthorities built a high wall across the island. Within the town itself the Portuguese were subjected to Chinese law, even in criminal matters. This Chinese régime did not end until 1849, ${ }^{1}$ and the Portuguese tenure of Macao was not definitely established until China ceded the territory, four square miles in extent, in 188\%. The population of the colony is reported now to be ninety-five per cent. Chinese, the commerce of the port is nearly all in the hands of natives, and the Chinese are largely left to their own administration of affairs.

The Brit- Directly across the narrow bay or river northward from ish colony of Hongkong Macao is the British colony of Hongkong. The island and a small portion of the peninsula near it were ceded by China in 1842. By the cession of Kowloon in 1850 and chiefly by the ninety-nine year lease of 1898 the area of Hongkong has been increased from less than twenty-nine to more than four hundred and five square miles. The excellent harbors and bays of Hongkong are the principal rendezvous of the British navy in Asiatic waters, and the foreign shipping of the port nearly equals that of New York, London or Hamburg. In government Hongkong is a crown colony, and though there has been some desire upon the part of the

of reference; it contains full information regarding trade and residence at the open ports and has excellent maps of these ports; Dennys and Mayers, Treaty Ports of China and Japan, London, 1867, also contains a very full history and description of the open ports and has excellent maps; Smith, D. W., European Settlements in the Far East, London, 1900 .

"According to a return of the Imperial Customs authorities the total number of foreigners resident in the open ports of China was 27,227 at the end of 1904. Among them were 5,981 British, 9,139 Japanese, 3,220 Americans, 1,871 Germans, 3,387 Portuguese, 1,374 French, 278 Spaniards, 366 Italians, 308 Russians, 286 Belgians, other nationalities being represented by very few members. About one-half of the total number of foreigners resided at Shanghai." Statesman's Year-book, 1906, p. $762-3$.

Dennys and Mayers, Treaty Ports, p. 209. 
foreign residents to organize a municipality for the city of Victoria, the fact that ninety-seven per cent. of the population of the colony is Chinese, has deterred the British authorities from venturing to remove the control of affairs from the Colonial Office. The various Chinese communities are permitted to regulate and administer their own affairs under some supervision. The proximity of this colony to the great city of Canton and to Macao has necessitated the making of very full and explicit conventions and Orders in Council for the extradition of criminals. ${ }^{1}$

Previous to 1842 foreign ships trading at Canton were not allowed to approach the city nearer than a point in the river several miles below. There they transferred their cargoes in mid-stream to and from native junks. After the treaty, the British obtained the setting apart of land at the junction of two rivers outside of the eity for rental to foreigners. This land was later separated from the surroundings by a broad canal and a wall, and it came to be known as the Shamien (Chinese for Sand Flats). There was also an American concession; in fact the regulations for governing it were approved by Mr. Cushing before he left China in $1844 .^{2}$

In general the United States has not favored the granting of separate or exclusive concessions of land at the various ports to the several treaty powers. It has preferred a policy of coöperation. The announcement of this policy by the American minister, Anson Burlingame, in 1863 was occasioned by the apprehensions then prevalent that such setting apart of land might be the first step in the development of a permanent lease or outright cession of territory. ${ }^{3}$ The British authorities disclaimed any such intention. Moreover, they declared that foreigners of all nationalities were permitted to rent land on the British concession at Shanghai without in any way impairing their extraterritorial rights under the treaties.

\footnotetext{
1 Indexes of the Britlsh and Foreign State Papers and of Hertslet's Commerclal Treatles.

2 Sen. Doc. 67, p. 87 (vol. 2), 28th Cong., 2d Sess.

s Dipl. Corr. 1863, pt. 2, p. 859.
}

The foreign settlement at Canton

The coöperative policy respecting the foreign settlements 
Claim of French furisdiction

German concessions at Tlentsin and Hankow

The French authorities appear to have claimed full territorial jurisdiction within their concessions, but the claim has never been admitted by Great Britain or the United States. This question of jurisdiction arose in $\mathbf{1 8 9 8}$ when it was proposed to extend the boundaries of the three concessions. ${ }^{2}$ Within the proposed French extension considerable land held by Americans was included. In order to avoid any possible claim of jurisdiction, it was decided to survey the boundaries of the extension so as to exclude the American property. ${ }^{2}$

Following an exchange of notes between Germany and China, and under arrangements made between the local Chinese authorities and the consuls in 1895, the German government has obtained concessions of land at Tientsin and Hankow. ${ }^{3}$ Germany claimed that separate concessions were necessary, because of the impossibility of securing satisfactory sites for business buildings in the existing concessions and because at Hankow the crowding of the wharves in the British concession and the preference given to British shipping had resulted in a practical exclusion of German ships from such privileges. It is said to be the policy of Germany to require that any foreigner who may be permitted to rent land in the German concession shall submit himself in respect to such property to the regulations for the administration of the concession and to the jurisdiction of Germany so far as these regulations are concerned ; ${ }^{4}$ but neither the treaty nor the agreements between the Chinese officials and

\footnotetext{
${ }_{1}^{1}$ The American concession lies north of the British and the French south of it and next to the Chinese city. The British and American concesslons have been united under a common municipal administration since 1854 .

${ }^{2}$ For. Rel. 1899, p. 143.

${ }^{3}$ Staatsarchiv, vol. 61, p. 229, 233.

For the land regulations of the British concession at Hankow, approved May 5, 1893, see Brit. and For. State Papers, vol. 85, p. 763: slight amendments were approved March 17, 1896, ibid., vol. 88, p. 203. For the land regulations of the British municipal extension at Tientsin, approved March 31, 1898, see Brit. and For. State Papers, vol. 90, p. 1004. For the land regulations of the British concession at Chinkiang, approved September 11, 1894, see Brit. and For. State Papers, vol. 86, p. 153.

- Staatsarchiv, vol. 61 , p. 227 .
} 
the German consuls of October 5, 1895, for Hankow, and of October 30, 1895, for Tientsin, announce such a requirement, and it is a well settled principle of extraterritoriality that no citizen or subject of a treaty power can, except by expatriation, divest himself of the rights guaranteed by treaty. ${ }^{1}$

The Japanese government stipulated in the protocol of November 10, 1896, that a settlement for the exclusive use of Japanese should be set apart withont delay at Shanghai, Tientsin, Amoy and Hankow upon its own demand. ${ }^{2}$ A small concession for Japanese residents at Amoy was made in $1899 .^{3}$

The number of separate land concessions in China and in Korea has largely increased since $1894 .{ }^{*}$

Immediately after the making of the treaties of 1843-5 the prosperity of Shanghai began developing, and before the treaties of 1858 were negotiated, the city had taken the place of leading importance formerly held by Canton.

The fortunate situation of Shanghai near the mouth of the Yangtse River, upon which and the great system of

${ }^{1}$ Supra, p. 91. The land regulations for the British municipal extension at Tientsin, see footnote 2, supra, contain a similar provision in the preamble, but modify it with the expression that it is understood that this obligation of foreigners is derived from their individual assent, approved by their national authorities.

Mayers, Chinese Treaties, ed. 1897, p. 191.

In pronouncing the judgment in Macdonald $i$. Anderson. British Consular Court at Tientsin, January 16, 1904, Mr. Justice F. S. A. Bourne said: "The Tientsin Britssh Municipal Extension is, as I understand, an area handed over by the Chinese Government to be municipally controlled by the British Local Authorities. There was no demise of the land, as there was by the Chinese to the British government in the case of the Tientsin British Concession. The native proprietors may hold their land thereon, or sell to foreigners of any nationality as they please. In fact the conditions are much the same as those under which the Shanghai Settlement is held. The Sovereignty undoubtedly remains in the Emperor of China." North China Herald, vol. 1xil, p. 248, February 5, 1904.

${ }^{3}$ For. Rel. 1899, p. 150 . For the land regulations and by-laws of January 10, 1902, of the settlement at Kulanger, Amoy, see MS. Dept. State, U. S. Consul at Amoy, No. 8, February 4, 1902.

* For land regulations Chenampo and Mokpo, Korea, of October 16, 1897, see For. Rel. 1898, p. 478, and Brit. and For. State Papers, vol, 91, p. 1177. For those at Kunsan, Masampo, Songchin, Korea, of June 2, 1899, see Brit. and For. State Papers, vol. 91, p. 1190. 
canals radiating from it, the trade of all central China is borne, has made the city one of the leading mercantile centers of the world.

Orlgin of the foreign munlcipality

Organization made perma nent in 1854

In 1846 and 1848 the British consuls and the Chinese intendants of the circuit agreed upon the boundaries within which the rental in perpetuity of parcels of land by foreigners was to be facilitated, and about the same time similar arrangements were effected by the French and American consuls. These arrangements were called land regulations, and, while they prescribed the methods of acquiring and holding land, they also provided certain rules as to payment of taxes for the maintenance of highways and wharves.

The validity of these early land regulations for the British and American concessions, so far as concerned individuals of other nationalities, was much questioned. When the Taiping rebels approached the city, the imperial authorities abandoned it, and the consuls, assisted by their national naval forces, organized the residents for the defense of the settlement. One of the most serious phases of the situation was that a very large number of Chinese had taken refuge within the concessions and there was much disorder among them. The foreign residents had previously been providing for the security, order and cleanliness of the concessions by authorizing committees to act for them and to collect moneys for public improvements. Such a committee was that of roads and jetties, which had a very important part in the development of the settlement. But the desire for a permanent municipal organization had become so general in 1854 that, with the approval of the ministers, the consuls and the Chinese intendant of the circuit, a set of land regulations providing for a full municipal government of the three concessions, British, American and French, was adopted in a public meeting of the land-holders. ${ }^{1}$ The land regulations were revised and largely amplified in 1866 and with sundry lesser modifications still remain in force. ${ }^{2} \mathrm{Be}$ -

2 Sen. Ex. Doc. 22, p. 125, 158 (vol. 8), 35th Cong., 2d Sess.

2 The American consul-general, Mr. G. F. Seward, took a leading part in the framing of the revised regulations. They are printed in 
fore the regulations of 1866 were adopted, the French authorities had organized and they have since maintained a separate municipality upon their own concession.

The land regulations of 1866 consist of a preamble and $\begin{gathered}\text { Regula- } \\ \text { tions of }\end{gathered}$ twenty-nine articles with appended by-laws. The phrase in 1866 the preamble, which recites that the regulations are for the 'peace, order and good government' of all persons residing on the land concessions, is the common form in which authority has been given to British ministers to provide regulations in countries where extraterritoriality prevails; the language that follows declares that the original regulations, those of 1854 , with the revision of 1866 , rest upon the authority of the ministers, the consuls and the local representative of the Chinese government-the authority of the consuls and the Chinese representative in respect to setting aside land for the residence of foreigners being stipulated in the British, American and French treaties of 1843, 184t and 1845 respectively. The regulations have effect and are binding upon all persons residing or being within the limits of the land concessions.

The first article of the regulations defines the boundaries of the land set apart for rental to foreigners, the next articles pertain to the methods of acquiring land, registering titles, and paying the ground rent to the Chinese government, and the following articles to the apportionment and collection of municipal taxes. It is provided that there shall be a municipal council of nine members elected annually by the taxpayers and charged with the general administration of public affairs; the council has power to appoint officials, control funds, make additional by-laws and cause legal action to be taken before their respective consuls or the Chinese authorities against persons who may be charged with breach of the regulations. It is provided that no member of the council or official acting under authority of the regulations shall be personally liable for anything done for

Dipl. Corr. 1867 pt. 1, p. 499-48, in Sen. Misc. Doc. 89, p. 179 (vol, 1), 47th Cong., 1st Sess. See also Appendix VI. 
the purpose of executing the regulations; but the council may be sued as a body, and notice to the chairman is to be regarded the same as the service of a process. The court before which the council is sued is no longer the judicial officer or consul of the defendant at Shanghai, but a court consisting of three consuls, ehosen annually by the consular body in that city. ${ }^{1}$ It is also provided that upon the requisition of ten of the electors of the municipal council, the consuls, collectively or singly, may summon a public meeting for the consideration of anything connected with the interests of the municipality, and that under certain limitations, resolutions may be adopted, which shall have the force of a municipal regulation. Finally, the senior consul is to request the taotai to direct the headmen of the several communities, guilds and the like, to elect annually three Chinese delegates, with whom the municipal council shall consult concerning the affairs of the native communities. The bylaws resemble municipal ordinances such as are common in the cities of England and the United States. ${ }^{2}$

The legality of the municipal ordinances in their bearing cipal council against a Mr. Reid to compel payment of taxes. The defendant denied that the plaintiffs were a legally constituted body, possessing powers of taxation over himself and his property, and he claimed that he was amenable only to the laws enacted by the United States Congress. The plaintiffs relied for the legality of their action upon the land regulations of the settlement submitted to the foreign ministers at Peking and approved by them in 1869 . But the defendant disputed the authority of the American minister to make him in any way liable to the demands of the municipal council of Shanghai or any other such body. The consul-general, sitting as judge, gave his opinion that

${ }_{2}$ The Court of Consuls Rules of 1882 are printed infra, Appendix VII-1.

2 The municipal council publishes an annual report. In 1902 the area of the concesslons was said to be eight and two-thirds square miles, and the mileage of roads, 76 . 
the approval of the land regulations and the municipal ordinances by the minister and indirectly by the Department of State had placed them under the sanction of the treaties and of the Acts of Congress pertaining to foreign jurisdiction, and that Mr. Reid, in choosing to reside within the foreign settlement and to enjoy the advantages of a well administered municipality, had made himself liable to pay his equitable proportion of the municipal taxes. ${ }^{1}$ Upon the same grounds, it may be added, the legality of the municipal police regulations was upheld in 1887 in instructions by Secretary of State Bayard. ${ }^{2}$

One of the most important questions in regard to the settlement is the precise definition of the jurisdiction of China over it. In conformity with the treaties China retains territorial jurisdiction over all the land concessions at the various ports. The treaties under which foreigners were permitted to rent land from the native owners stipulated neither that there should be definite areas assigned to each of the treaty powers nor that the right of renting land in any way involved special rights of jurisdiction. The British treaty of 1843 , the terms of which were repeated in the American treaty of $184 t$ and the French of 1845, with no essential modifications introduced into the treaties of 1858 , provided as follows: "Ground and houses, the rent or price of which is to be fairly and equitably arranged for . . . shall be set apart by the local officers, in communication with the Consul; and the number of honses built, or rented, will be reported annually to the said local officers by the Consul, for the information of their respective Viceroys and Governors; but the number cannot be limited, seeing that it will be greater or less, according to the resort of merchants." ${ }^{3} \mathrm{Al}-$ though the arrangements made between the consuls and the local officers made concessions of definite areas within which this right of renting land was to be enjoyed, they did not and could not, since they were not of the nature of treaties, ex-

1 For. Rel. 1882, p. 123-32.

${ }^{2}$ Wharton, Internat. Law Digest, Appendix, p. 852.

${ }^{3}$ Brit. and For. State Papers, vol. 31, p. 133. 
tend, amplify or in any way concern extraterritorial jurisdiction.

Yet in the course of time the foreign interests at Shanghai have become so large and their protection mutually so desirable, that China has not uniformly insisted upon exercising the prerogatives of sovereignty. ${ }^{1}$ The foreign municipality has thus come to be, in all essentials, free to govern the inhabitants upon the concessions, subject to the approval of the various consuls and ministers, and reserving to these consuls and to Chinese officials the hearing of cases and execution of judgments against their nationals. In time of war, as in the Tonquin war of $185 t-5$, the war with Japan in 189-1-5, and the war of 1901-5 between Japan and Russia, every effort to keep the port of Shanghai neutral has been successful. ${ }^{2}$

The

Chinese or 'mixed' court

The fact that China retains territorial jurisdiction over the foreign concessions at Shanghai is present to the minds of residents there in the operations of the courts in which Chinese defendants are tried. There is a Chinese court in the Anglo-American settlement and another in the French. Each of these courts is locally known as a 'mixed' court for the reason that while a Chinese judge presides and Chinese law is presumed to be the law of the court, whenever a foreigner is a party to the cause, some consular officer, not necessarily of the same nationality as the foreigner concerned, sits with the Chinese judge and has the virtual decision of the case through his assenting to or dissenting from the opinion of the judge. The 'mixed' court is the busiest of all courts at Shanghai and its difficulties are greatest. Though repeated efforts have been made to induce the Chinese government to introduce improvements, it has not yet provided either a satisfactory code of law or a satisfactory system of judicial administration, and the con-

${ }^{1}$ For instance, in 1900 , the military escort of $\mathrm{Li}$ Hung Chang did not pass through the foreign settlement, because the municipal athorities protested that the Chinese government might thus establish a precedent for sending its troops into the city.

${ }^{2}$ For. Rel. 1894, Appendix I, p. 5s; see also For. Rel. 1874, p. 339; 1875, pt. 2 , p. 776 . 
suls, on their part, usually appoint as an assessor a junior consular officer, selected rather for his knowledge of the Chinese language than for his knowledge of law. ${ }^{1}$

In 1903 the governor of the province in which Shanghai is situated undertook to suppress a revolutionary society whose The Supao journal, the Supao, was published in the vernacular within the bounds of the Anglo-American municipality. The consular body, before allowing warrants for the arrest of the six Supao journalists to issue, had received the proposal of the taotai that the accused should be tried within the bounds of the settlement, and, if sentenced, should serve their penalties in the same locality; but when the taotai learned that the viceroy at Nanking would not consent to this proposal, he endeavored to repudiate his agreement and demanded that the Chinese be delivered up at once to be tried whenever and wherever it might please the government of China. About a year earlier than this event the foreign ministers at Peking had made a rule that no accused person arrested within the settlement should be given up to Preliminaty trial in Shangnai rethe Chinese authorities without a preliminary trial before the 'mixed' court, a process resembling the preliminary inquiries in extradition proceedings. During the delays the imprisoned journalists again wrote seditious articles and succeeded in publishing them, whereupon the 'mixed' court granted an injunction, countersigned by the senior-consul, sealing the Supao office and presses. The municipal police were so slow to enforce the order that the Chinese government was convinced of the unwillingness of the municipal

1 See also supra, p. 85-6. Rules for the 'mixed' court at Shanghal, April 20, 1869, Mayers, Chinese Treaties, ed. 1897, p. 236; the rules are printed infra, Appendix VII-2.

An amendment to these rules was publlshed June 13, 1901, by the British, Amerlcan and German consuls-general, providing that a foreign assessor should sit in the 'mixed' court in all cases, including those to which natives alone were parties. This amendment appears to be contrary to the treaties. Amendments proposed in 1906 are printed infra, Appendix VII-3.

On June 10, 1902 provisional rules were adopted defining the respective jurisdiction of the 'mlxed' courts of the international and French Settlements; Brit. Parl. Papers, 1903, vol. iv, p. 603. They are printed infra, Appendix VII-4. 
council to coöperate in proceeding any further in the matter. Among the residents on the settlement there was much apprehension lest the imperial government, if it should accomplish its purpose in this instance, might use the incident as an entering wedge for eventually claiming the right to arrest on the settlement and remove at will any Chinese subject however important his business relations. The government, on the other hand, claimed that without drastic measures Shanghai would become a hotbed for the dissemination of revolutionary ideas. When the municipal council undertook to communicate with the foreign ministers, it was informed that it was not considered to have any right to intervene, that such matters belonged solely to the consular and diplomatic officials. For several months things were dead-locked. The British minister was instructed to refuse the surrender of the Chinese except upon the findings of the 'mixed' court approved by a foreign assessor; but, without consulting an assessor, the Chinese magistrate sentenced the journalists to imprisonment for life. Then the ministers at Peking, excepting the French and Russian, joined in requiring that the sentence in the 'mixed' court be annulled and the case reheard with the approval of the assessor. Finally, notice being given to the Chinese authorities that unless sentence were pronounced, the prisoners would be released at the end of a month, the proceedings of court were taken in regular form and the two principal offenders were sentenced to hard labor with subsequent banishment from the settlement. ${ }^{1}$

Case of the Japanese sples
At the outbreak of war between China and Japan in 1894 two Japanese, suspected of being spies, were arrested on the French concession at Shanghai. China had acceded to the proposition of Japan that the United States should exercise friendly offices for protection of Japanese subjects in China during the war, and upon this ground the two suspected men were placed in the custody of the American consul-general

1 North China Herald, July 10, 1903, p. 63, 99; July 24, p. 175; August 28, p. 469, and May 27, 1904, p. 1121. 
pending investigation. The Chinese minister at Washington then complained that the consulate was giving protection to Japanese spies. The State Department sent telegraphic instructions to release the Japanese at once, that the consulate could not be made an asylum for the offenders, and that lending friendly offices had in nowise extended the privileges of extraterritoriality. ${ }^{1}$

To release the men without preliminary investigation before the Chinese or so-called 'mixed' court on the settlement, in which no judgment could be given without the approval of the foreign assessor, was contrary to customary practice in time of peace. The ordinary method, as provided in the regulations of 1869 , was to bring before this tribunal all Chinese charged with crimes or misdemeanors on the settlement and all foreigners so charged not protected by treaty; and in this 'mixed' court final judgment was to be given except in case of certain graver offenses punishable by death and various degrees of banishment, which were to be sent up for revision to higher Chinese authorities. ${ }^{2}$

The object of requiring a preliminary investigation, the result of which the foreign assessor may or may not approve, is to prevent Chinese officials from interfering with the orderly government of the municipality by arresting and removing from the settlement, without due cause, Chinese or others who may have important connections with the interests of foreigners.

The residents within the concessions desired to establish Desire of a precedent of following a like procedure toward the subjects of any power that might be at war with China. If the neutrality of the settlement were not thus to be guarded, ity an outbreak of war with Great Britain, France, the United States, Germany or Japan, nations largely represented at Shanghai, would bring consternation and ruin to the foreign community in general. During the Tonquin war between France and China, Russia was authorized to use 
friendly offices for the protection of Frenchmen in China, and certain of them, it is said, being arrested in Shanghai, were actually brought before the Russian consul for hearing without an effort on the part of China to interfere in any way.

Responding to these representations, the government at Washington declared that it would be glad to see an arrangement made between China and other interested powers which should better define jurisdictional rights at Shanghai, but that it doubted the willingness of the authorities at Peking to yield jurisdiction of subjects of a belligerent power suspected of coöperating in the furtherance of hostilities against China. It was further pointed out that a Japanese imperial ordinance had been issued declaring that one of the first results of the state of war was to suspend the conventional guaranties of extraterritoriality as between the two countries and to make Chinese subjects in Japan wholly amenable to the jurisdiction of Japanese courts; and it was thought that China was therefore entitled reciprocally to assert jurisdiction over Japanese in that country.

Retention of Chineso soverelgnty over the leased areas

In 1897 ard 1898 China made leases of the ports of Kiaochow, Port Arthur and Talienwan, Weihaiwei in North China and Kuang-Chow Wan in South China, to Germany, Russia, Great Britain and France, respectively. According to the terms of the lease of Kiaochow to Germany "China retains her sovereignty over this territory," yet, "during the continuance of the lease China shall have no voice in the government or administration of the leased territory." 1 The Russian lease of Port Arthur and Talienwan was not to "prejudice China's sovereignty" over that territory, yet Russia claimed jurisdiction and actually tried Chinese for crimes against Russians. The British lease of Weihaiwei was to continue as long as Port Arthur should "remain in the occupation of Russia," and within the territory of Weihaiwei Great Britain was to have "sole jurisdiction," yet within the walled city of Weihaiwei "Chinese officials," so

1 Staatsarchlv, vol. 61, p. 1. 
reads the treaty, "shall continue to cxercise jurisdiction, except so far as may be inconsistent with naval and military requirements for the defense of the territory leased." 1

The question whether the leasing of these areas to Euro- Suspenpean states had caused extraterritorial jurisdiction in them sorelgn to cease was answered by the powers, excepting Japan, in the affirmative. The ground of decision taken by the government at Washington was that the mention of China's jurisdiction in the leased retaining sovercignty appeared to have been made merely with the intention of cutting off possible future claims of the lessees that the sovereignty over the territory had been permanently invested in them, and the fact that the terms of the leases admitted the exercise of European jurisdiction implied that China had intended to retain and could retain only a nominal and limited jurisdiction. With this opinion of the solicitor of the department before him, the Secretary of State gave instructions that consuls in whose districts the leased areas had formerly lain should not exercise any consular functions in them until exequaturs recognizing their official character had been obtained for them from the respective European governments. It was not expected that these exequaturs would include the right to exercise extraterritorial jurisdiction. ${ }^{2}$

The Japanese government claimed that jurisdiction was an essential feature of sovereignty and could not pass with a mere lease, and that Japan had no agreement with China under which China could grant to foreign powers jurisdiction over Japanese subjects and their property in Chinese territory. Japan therefore declined to admit Russian jurisdiction over a Japanese subject arrested at Port Arthur upon suspicion of being a military spy, and the Russian government yielded to Japan so far as to order that the suspect be delivered to Japanese authorities.

1 Brit. and For. State Papers, vol. 90, p. 16; see also For. Rel. 1900 , p. $382-90$.

${ }^{2}$ For. Rel. 1900, p. 382. See also For. Rel. 1898, p. 182, 533; 1899, p. 128; 1903, p. 84 . 


\section{GROUNDS OF RELINQUISHING JURISDICTION}

The extension of European soverelgnty leading to cessation of furisdiction

Retention of native law in European colonles
When any portion of oriental territory comes into the absolute possession of a European power, as when Hongkong was ceded to Great Britain in 1841, when Madagascar was declared a French colony in 1896 and when the extreme eastern and western districts of Turkey passed under Russian and Austrian dominion in 1878, the necessity of extraterritorial protection in such a region is at an end. The sovereignty of the European states extends to its new possession, and an incident of this sovereignty is the obligation to administer justice in conformity with western conceptions of justice.

This extension of European sovereignty obviously involves the necessity of preserving much native law and custom. Such is the condition of things in British East India where a very ancient and elaborate system of native law, much of it Mohammedan, exists side by side with the common law and the statutes, so far as these have been extended to East India by Act of Parliament. ${ }^{1}$ Similarly in Algiers, where, although extraterritorial jurisdiction ceased in 1830 when the Dey of Algiers surrendered the city to the commander of the French army, and although in $18 \% 0$ the country was made into departments of France coequal with the departments in Europe, both the ancient Mohammedan law and law of French origin are administered even to-day in French and native courts. ${ }^{2}$ In Mada-

1 Ilbert, The Government of India, Oxford, 1895, p. 124; Strachey. India, Its Administration and Progress, London, 1903, p. 91.

${ }^{2}$ Leroy-Beaulieu, L' Algerie et la Tunisie, Paris, 1887, p. 266. The conquest of Algiers was not complete until 1857. 
gascar also there is a double system of courts, French and native, but in Madagascar, as well as in Algiers, the rights of foreigners are adjudicated only in courts presided over by French judges. ${ }^{1}$

It is important to distinguish the effect of outright Military change of sovereignty from that of mere military occupation. When a French army had completed the conquest of Madagascar, the Malagasy Queen was obliged to sign a pation and suspension of juristreaty on October 1, 1895, recognizing a French protectorate over the island. About six months later, while changes in the political relations of France and Madagascar were apparently leading toward annexation, the French government, through its ambassador at Washington, expressed the desire that instructions be issued looking to the discontinuance of jurisdiction in the American consular court. In reply, the Secretary of State, Mr. Olney, requested a categorical statement that French sovereignty had been established. At the same time the American consul was authorized to suspend until further instructed the exercise of judicial functions in all cases where coöperation of an established French court was available for disposition of judicial cases affecting American citizens. On August 6, 1896, the French National Assembly declared Madagascar a colony of France. This act was considered by the American government as implying the abrogation of its treaty with Madagascar of May 13, 1881, and as substituting for it the treaties between the United States and France. By arrangements between the two governments the jurisdiction continued until matters were settled that were pending in court on the following October 16, the date when the resident-general declared the French courts open. ${ }^{2}$ The attitude of the British government resembled that of the American in respect to desiring of France an explicit declaration that Malagasy sovereignty was extinct and French sovereignty substituted in its place before it would recog-

\footnotetext{
${ }^{1}$ Leroy-Beaulieu, De la colonisation chez les peuples modernes, 5th ed., Paris, 1902, vol. 1, p. 475-80.

${ }^{2}$ For. Rel. 1896, p. 126, 133; 1897, p. 152.
} 
nize the abrogation of treaty relations with Madagascar and thus relinquish its foreign jurisdiction. ${ }^{1}$ Until such a declaration was made, the effect of military occupation was only to enable France to obtain a suspension of jurisdiction.

Samoa When, howerer, during an armed conflict between Germany and one of the rival chiefs of the Samoan Islands in 1899, the German naval commander proclaimed martial law, the American Secretary of State, Mr. Bayard, instructed the minster at Berlin to inform the German Foreign Office that the United States expected that German officials in Samoa would be instructed scrupulously to abstain from all interference with American citizens and their property in Samoa, that no assumption or extension of German jurisdiction over American citizens or their property would be caused by the German declaration of martial law, and that no such jurisdiction would be recognized or conceded by the United States. ${ }^{2}$ But in view of the peculiar complications of Samoan affairs then and later, this incident cannot rightly be regarded as establishing a precedent contrary to the policy pursued in Madagascar. When the Russian army apTurkey proached Constantinople in $187 \%$, the city was placed under military government, but consular jurisdictional authority was not suspended. ${ }^{3}$ The military occupation of Manchuria by the armies of Japan and Russia did not, it is believed, affect consular jurisdictional rights except to cause their temporary suspension in localities where active military operations were going on.

Juris- diction in European protectorates

In respect to retaining or relinquishing jurisdiction in territories that have become protectorates of European powers, a diversity of practice has existed. Although Great Britain formally recognized the protectorate of France over Madagascar in 1890, it was not until 1896, when Madagascar became a French colony, that Great Britain relinquished jurisdiction, and then only upon the condition that France reciprocate by renouncing its jurisdictional rights in British

2 Brit. and For. State Papers, vol. 89, p. 1082.

- For. Rel. 1889, p. 191.

- For. Rel. 1877, p. 580. 
Zanzibar. ${ }^{1}$ Without formal recognition of the French protectorate over Madagascar the United States also declined to relinquish jurisdiction so long as Madagascar was a protectorate, with no French courts estahlished and available for the disposition of cases affecting American citizens. A Tunis different policy was followed when the French protectorate over Tunis was announced in 1881. Tunis is believed still to remain a protectorate, and relations with it are controlled through the foreign office, but in 1883 Great Britain relinquished jurisdiction by Order in Council and other European governments have relinquished it by legislation or by convention with France. ${ }^{2}$ The American Secretary of State, Mr. Frelinghuysen, referred the matter to Congress with the result that a joint-resolution was passed authorizing the President to issue a proclamation relinquishing jurisdiction whenever in his judgment a system of justice was established in Tunis under which the rights of American citizens would be fully and permanently protected; but such a proclamation was not made, and it was not until a special convention between France and the United States in regard to Tunis was effected on March 15, 1901, that the United States formally relinquished jurisdiction. ${ }^{3}$ The United States relinquished jurisdiction in Zanzibar also, which had been a British protectorate since $1890 ;{ }^{4}$ and to this end a convention with Great Britain was signed February 25,1905 , to take effect when other nations shall have likewise renounced extraterritorial privileges therein. ${ }^{5}$

As to other protectorates, namely, Borneo, whose entire territory was converted into the British protectorate of

${ }^{1}$ Brit. and For. State Papers, vol. 89, p. 1082.

${ }^{2}$ Brit. and For. State Papers, vol. 74, p. 694; vol. 75, p. 469, 1007, 1166, 1271. The number of British subjects from Malta residing in Tunis in 1863 had been estimated at 10,000; in that year they were, by convention, made subject to the law of Tunis in regard to their real property in that country; Dipl. Corr. 1864-5, pt. 4, p. $437 ; 1868$, pt. 2 , p. 174 .

For. Rel. 1883, p. 483; Congressional Record, 47th Cong., 2 d Sess., vol. 14 , pt. 1 , p. $440,455,710$; pt. 4, p. 3660 ; Compilation of Treaties in Force, Sen. Doc. 318, p. 949 (vol. 37) 58th Cong., 2d Sess.

- Brit. and For. State Papers, vol. 82, p. 653.

- Archives diplomatiques, 1905 , pt. ili, p. 262-4; see also supra, p. 20. 
North Borneo, and the Dutch protectorates of East, South and West Borneo in $1891 ;^{1}$ and Tonga, which was made a British protectorate in 1899 and at length became essentially a British possession in $1904^{2}$ - the United States has taken no action whatever toward relinquishing its treaty rights of jurisdiction. But in view of the practice of European governments and of the recent suspension of jurisdiction in the leased areas of North China, it may be assumed that the United States would either retain, suspend or relinquish jurisdiction in a protectorate according to the extent to which the protecting power actually undertook the administration of justice in it. Another determining factor in European practice is the degree of reciprocity shown with respect to withdrawing jurisdiction in protectorates, for example, the British withdrawal of jurisdiction from Madagascar in return for French withdrawal from Zanzibar, and the British withdrawal of jurisdiction from Samoa in return for German withdrawal of it from Tonga. ${ }^{3}$

Jurisdiction In newly Independent states

When a portion of an oriental country has become independent, as when Greece, Servia and Roumania separated themselves from Turkey and established new governments, the question of retaining or discontinuing extraterritorial jurisdiction in them has been determined by general acts of the powers, with subsequent action by each power for itself. The powers did not specifically relinquish jurisdiction in the main acts relating to the establishment of independent government in Greece, and the question does not appear to have been regarded as important. By the general act of the Congress of Berlin of 18\%8, recognizing the independence of Servia and Roumania, it was provided that the extraterritorial rights secured by the capitulations from the Ottoman Porte should continue in force in these principalities until modified by mutual consent with each foreign power concerned. The United States made treaties with Servia and

${ }^{1}$ Brit. and For. State Papers vol. 83, p. 41.

2 As a matter of fact the United States never exercised any of its jurisdictional rights under the treaty with Tonga of October 2, 1886.

B Brlt. and For. State Papers, vol. 92, p. 1063, 1064. 
Roumania in 1881. The Roumanian treaty contains no explicit renunciation of extraterritoriality. The Servian treaty made a qualified renunciation under which the United States retained jurisdiction, except as to real estate, in mixed cases involving other foreigners whose governments should not have renounced jurisdiction. This provision had only a temporary effect, for jurisdiction was soon relinquished by Austria, France and Great Britain, and in 1886 Servia and Turkey entered into a convention mutually relinquishing extraterritoriality each in the territory of the other. In an earlier instance, that of the independence of Greece in 1830, the régime of the capitulations was not continued, for the reason, apparently, that the new kingdom was placed under the protection of Great Britain, France and Russia. The United States recognized the independence of Korea by making a treaty with its government on May 22, 1882, and in the same treaty stipulated for extraterritorial jurisdiction in terms which, though they do not refer to continuance of jurisdiction like that enjoyed in the Chinese empire, establish a system closely resembling it. When, therefore, a new oriental nation has come into existence by separation from Turkey, as Servia and Roumania became separate in 1878 , the régime of the capitulations has been made to continue. Greece was a protected state; and in Korea, while the jurisdiction was newly set up, it was made closely to resemble what existed in China and Japan.

The one nation of the East which has so developed its system of jurisprudence, adapted and codified its laws and improved its administration of justice, as to convince the western states of the advisability of withdrawing their foreign jurisdiction, is Japan. ${ }^{1}$ About ten years after the making of the commercial treaties, Japan emerged from a civil war in which the long domination of the military and feudal classes was overthrown. The war had bronght to the leadership of the nation a group of very able men united in loyalty to the highly intelligent and progressive Emperor Mutsuhito.

1 The progress of Japan toward judicial autonomy is described in Foster, American Diplomacy in the Orient, Boston, 1903, p. 344-64. 
The embassy of 1872 to America and Europe
In 1872 , at the end of the stipulated period of fourteen years when negotiations for the revision of the treaties was to be undertaken at the desire of either party, the Emperor sent a large embassy, consisting of Prince Iwakura, who was minister of foreign affairs, and the statesmen Kido, Okuba, Ito, Yamagutsi and others, to America and Europe in order that they might study western institutions and propose revision of the treaties. But the existing treaties, with their low customs tariff of five per cent., were considered more advantageous by the western powers than any new treaties likely to be accepted by Japan. ${ }^{1}$ Moreover, while there were prospects of improving the Japanese system of jurisprudence by adoption of western principles of law, they were still far from being ready to place in practice.

Therefore the only course open to the Japanese leaders, who realized that their nation would suffer 'oppression by treaty,' if the treaties of 1858 continued in force, was to develop the national institutions until they should command the respect of the western powers. This they accomplished through the ever increasing influence of merchants and others who were adopting western ways in the management of various enterprises; moreover, encouragement in the publication of newspapers was given and a national system of education instituted. In $18 \% 5$ the Emperor convoked popular assemblies to which he confided responsibility for local government. Meanwhile the administration of the central government was remodelled. For this purpose the services of able and experienced officials under other governments were retained by Japan, among them several Americans in the departments of education, the postoffice, the treasury and the foreign office. With the assistance of foreign jurists the laws were revised and the courts reorganized. The new codes of criminal law and procedure followed

2 The principal treaty concluded subsequently to those of 1858 was the Austro-Hungarian treaty of October 18, 1869. Its original text was in English. Its provisions beneftted the other powers through the operation of most-favored-nation clauses in their treaties; Neumann and De Plason, Receuil des traltés et des conventions conclus par l'Autriche, vol. 6, p. 42\%; Brit. and For. State Papers, vol. 59, p. 529. 
the model of the codes of France, the codes of civil and commercial law and eivil procedure the codes of Germany. These eodes came into operation gradually. They acquired full force in $1899 .^{1}$ The constitution of the Japanese empire had been promulgated in 1889.2

There was naturally some doubt among foreigners resident in Japan whether the Japanese government would be able to secure to them under new treaties, and without the operation of consular courts, the same degree of protection they were enjoying under the treaties of $1858 .^{3}$ Notwithstanding the continued protests of Japan against the irregularities and evils of the extraterritorial system, the European governments had again in 1878 refused to consider revising the treaties. In that year, however, the United States made a treaty conditionally acknowledging the right of Japan over her own import tariffs. In 1886 Count Inouye called a conference of the foreign ministers at Tokio and, after deliberations prolonged into the following year, finally ventured, upon his own responsibility, to concede that for all trials involving foreigners there should be a court made up of a majority of foreign judges sitting with the Japanese judges. The foreign ministers then demanded the right to choose these foreign judges and to prescribe what law and procedure and what manner of executing judgments should be followed. At this there was an outburst of general indignation among the Japanese, and Count Inouye lost his leadership in politics. During the conference the American government had shown a friendly attitude by concluding the treaty of extradition of April 29, 1886. In submitting it to

1 Parliamentary Papers, 1894, vol. xev1, Japan No. 1, p. 94. Kaneko, Les institutions judiciaires du Japon, Revue du droit internat. 1893, p. 338; Okamura, Progress of the Judiclal System of Japan, Jour. Soc. Compar. Legislation, 1899, p. 46; Hatoyama, The civil code of Japan compared with the French civil code, 11 Yale Law Jour., 296, 363; Masujima, The Japanese legal seal, and Modern Japanese legal instltutions, Transactions, Asiatic Soc. of Japan, vol. 17, p. 102, and vol. 18, p. 229 .

2 For. Rel. $18 \$ 9$, p. 535.

${ }^{3}$ Such apprehension was expressed by American and British residents in Japan even as late as the year preceding the inception of the new treaties; For. Rel. 1898, p. 450; see also Parllamentary Papers, 1894, vol. xcvi, Japan No. 1, p. 144. 
Negotiations with

Great Britain the Senate, President Cleveland said that the treaty had been made partly because of the support which its conclusion would give to Japan in her efforts towards judicial autonomy and complete sovereignty. ${ }^{1}$

The draft of a treaty proposed by Count Okuma for Japan to the Marquis of Salisbury, the British Secretary of State for Foreign Affairs, in 1889, contemplated that, for a period of five years from the conclusion of the treaty, consular jurisdiction should be territorially limited to the six foreign settlements, and to the open ports and other localities in which foreigners were permitted to reside; that outside of these localities Japan should have full jurisdiction, and that upon the expiration of the five year period consular jurisdiction and extraterritorial privileges were to cease throughout the territory of Japan, and the Japanese courts were thereafter to assume and exercise full jurisdiction. The proposed treaty was to contain rules for further determining the jurisdiction of the Japanese and British courts during the five year period. In advance of the abolition of the consular courts, British subjects were to be permitted to submit to the jurisdiction of Japanese courts by filing written declarations of their desire at the British consulates. It was also proposed, in the draft of a diplomatic note, that Japan should appoint a number of foreign jurists to act in the capacity of judges in the Supreme Court of Japan. The British counter-draft of the treaty and of the diplomatic note contained essentially the same provisions, but expressed them in entirely different language. ${ }^{2}$ Some months later Viscount Aoki, Minister of Foreign Affairs, informed the British minister at Tokio, Mr. Fraser, that his government desired the elimination from the proposed treaty of the provision for foreign judges in the Japanese tribunals, and, as reasons for this change, it was shown that the adoption of this measure would cause the vesting of rights and the growth of usages which it would be as difficult to modify as

1 Sen. Ex. Jour., vol. 25, p. 495.

- Parliamentary Papers, 1894, vol. xcvi, Japan No. 1, p. 2-24. 
were the treaties of 1858 , and that the judicial organization of Japan would, at the end of the five year period, be of nearly a quarter of a century's standing, with perfect independence and permanence under the guarantees of the constitution of 1889. Japan desired also that the proposed stipulations concerning the codification and promulgation of the laws of the Empire and the stipulations granting the right to acquire real estate should be withdrawn, and that reservation in reference to the right of aliens to be placed upon a national footing should be introduced. The counter proposal by Lord Salisbury of June 5, 1890, consisted of a commercial treaty with a protocol annexed, providing for the cessation of jurisdiction at the expiration of a minimum period of five years upon condition that, before the jurisdiction should be discontinued, the Japanese codes, then being elaborated, should have been in satisfactory operation for a continuous term of twelve months.

While negotiating with Great Britain as the power whose Final interests predominated, the Japanese government had also negotiamade propositions of treaty revision to the United States, Russia and Germany. The American government, while disposed to be favorable to the project of revision, regarded the favorable action of Great Britain as essential to its success, and in reliance upon this friendly attitude of the United States, Japan had made her chief efforts with Great Britain. Russia, it was believed, was willing to accept a treaty resembling the British draft of 1889 , while Germany insisted upon its own form of convention. ${ }^{1}$ The principal canses of delay in the latter part of the negotiations appear to have been the postponement of placing the new code fully in operation and the changes in the political leadership and the ministry. The British treaty, essentially following the draft of June 5, 1890, but including the provision for relinquishment of jurisdiction in the body of the treaty instead of in a protocol, was signed at London, July 16, 1894, by Lord Kimberley and Viscount Aoki. The American treaty

¿ Parliamentary Papers, 1894, vol. xcvi, Japan No. 1, p. 68. 
was signed at Washington by Mr. Gresham, Secretary of State, ant Mr. Shinichiro Kurino, the Japanese minister, November 2:2, 1894. All of the treaties of this group, except the French, came into operation on July 1i, 1899.

The

efforts of Turkey to have the forelgn

jurisdictional rights abrogated

The question of abrogating extraterritorial privileges in Turkey was considered at the Congress of Paris in 1856. The British, French, Prussian and Sardinian plenipotentiaries were disposed to favor revision of the capitulations. The plenipotentiaries of Turkey represented that the jurisdictional privileges of foreigners were an obstacle to the improvement of the administration of justice in their country. 'Tlue plenipotentiaries of other powers thought extreme circumspection necessary, and declared that an actual and permanently established reform, rather than those announced, should be regarded as the proper guaranty for proposing changes in the extraterritorial privileges. The outcome of the discussion was simply that the congress recorded a desire for the calling of a conference at Constantinople to deliberate further upon the question. ${ }^{1}$ Such a conference never assembled. A few years later the disposition of the powers to retain their jurisdictional rights in Turkey was shown in the numerous commercial treaties which corresponded in substance and approximately in time with the treaty of February 25, 1862, between the United States and the Ottoman Porte, the first article of which provided that all rights, privileges and immunities which had been conferred by the treaty of 1830 , excepting certain specified rights not connected with jurisdiction, were confirmed then and forever.

But since 1856 Turkish diplomacy has never been at rest upon this subsidiary 'eastern question,' commonly known in continental Europe as 'la question des capitulations.'? The Porte doubtless had the abolition of the privileges in mind when in $186 \%$ it conceded the right of foreigners to

1 Protocol of March 25, 1856.

"Pradier-Fodéré, La question des capitulations, Rev. de droit internat. 1863, p. 118; see also Brunswik, Etudes pratiques sur la question d'Orient, réformes et capitulations, Paris, 1869. 
hold real estate in 'Turkey and required of the powers that they grant to Turkey full jurisdiction in respect to the real estate rights of foreigners. Again, its protracted effort to prove some inconsistency or impracticability in Article IV of the American treaty of 1830 , and particularly the insistence of its minister at Washington upon obtaining further concessions after the matter had been thoroughly investigated and finally settled, may be reasonably supposed to have been connected with the general policy of trying to abolish foreign jurisdiction.

Between Turkey and Greece there was no formal recognition, until the commercial treaty of May $23,1855,{ }^{1}$ of the fact that the capitulations had remained in force in favor of Greek consular jurisdiction in Turkey, and then this recognition took merely the form of a most-favored-nation clause. ${ }^{1}$

After the war of $189 \%$ the Porte proposed as a condition of peace that Greece should renounce the privileges of extraterritoriality. The Porte also claimed that the war had terminated the treaty of 1855 and with it the right to claim those privileges. But the Greeks argued that extraterritoriality existed by virtue of agreements among the powers in 1830 and could therefore not be aljrogated because of the war. The two governments were in accord that crimes committed by Greeks upon Greeks should be tried in the Greek consular courts, and that, if a Turk were the injured party, the trial should belong to Turkish jurisdiction, but the Turks claimed the right to try offenses of Greeks against other aliens in Turkey, a class of offenses which Greece and the other European states maintained should be tried by the consul of the defendant. The Turkish government claimed that without this jurisdiction it could not guarantee protection to foreigners. The difference was submitted to arbitration and, under certain restrictions relating mostly to enforced collection of debts and bankruptcy, in regard to which there had been many serious problems, the rights of extraterritoriality of Greeks in Turkey were retained. The

1 Noradounghlan, Recueil, vol. 2, p. 443, Art.. 24. 
criminal jurisdiction as between Greeks and aliens was left as it had been. ${ }^{1}$

The Danublan principalltles

In 1878 the European powers in congress at Berlin determined the international standing of the Danubian principalities. As between Bulgaria and Turkey the treaty of Berlin made Bulgarians going into other parts of the Turkish empire subject to Turkish jurisdiction; as between Turkey and the independent principality of Servia, the subjects of Servia going into Turkey shall be treated, so reads the treaty, "according to the general principles of international law"; as between Turkey and the other independent principality of Roumania, the subjects of each in the territory of the other, so reads the treaty, "shall enjoy the privileges secured to subjects of other European powers." Whatever the exact meaning of these terms, the Turkish-Servian convention of $1896^{2}$ distinctly places Servians in Turkey under Turkish jurisdiction, and no stipulations upon this point are found in the printed conventions between Turkey and Roumania as late as the end of $1902 .^{3}$

As between the Danubian principalities and the European powers the capitulations were to remain in force until abrogated or modified by convention; Servia has already established its judicial antonomy and Roumania is undertaking to do so. In the protected states, Samos, Crete and Cyprus, though neither the law nor the administration of justice is Turkish, the régime of the capitulations has not been definitely abolished. The Ionian Islands, long an English protectorate, were annexed to Greece in 1863.

To such an extent in fact has the sorereignty of Turkey been impaired since the treaty of Paris of 1856, that the terms of that treaty make an ironical commentary on the admission of the Ottoman government into the 'concert of

'Strelt, La sentence arbitrale sur la question consulaire entre la Grèce et la Turquie (including the text of the award), Rev. de droit internat. 1902, p. 24, 178, 281, 527.

2 Noradounghian, Traités, vol. 4, p. 525, Art. 7.

schina, Richterliche Ingerenz der Konsuln in Rumänien (summary of a speech in the supreme court of appeals at Bucharest, 1901), Zeitschrift für internat. privat- und öffent. Recht, 1903, p. 306. 
Europe.' In spite of the guarantee of Turkish independence and territorial integrity, and of the recognition of the value of the reforms then proclaimed by the Sultan, in consideration of which the powers agreed not to intervene either collectively or separately in the internal administration of the country, not ten years elapsed before the Syrian massacres had horrified Europe and Turkey was threatened with the loss of both the Danubian countries and Egypt. Since that time the power of the Sultan has been prolonged chiefly by the jealousy of the European powers one of another, by the anxiety of the foreign creditors, by the shifting diplomacy of the Porte itself and by the increasing strength of the Turkish army.

The government of Turkey is an absolute monarchy. Its laws are merely decrees issued by the Sultan and his predecessors in interpretation of or as supplementary to the precepts of the Koran and the sayings ascribed to Mohammed. The Mohammedan religious precepts are very specific. They prescribe details of conduct so minutely that the faithful cannot conceive of justice except under the rules of the Koran. The leading theologians are also leading jurists. The local judges or cadis are men of religious training. They obey the Sultan because he is Mohammed's successor. It is the assumed obligation of the courts to obey instructions from the ministers of the Sultan. Arrests and imprisonments by executive direction are common, and occasionally there is a general order for the release from prison of all persons against whom there is no charge.

An effort has been made, but with uncertain and irregular results, to adopt legal principles from western public and private law. In the adoption of principles of commercial law there has been some progress. But it is obvious that so long as the Turkish state remains unsecularized, the body of Turkish jurisprudence must be immutable and unprogressive.

The measure of success attained in the system of mixed tribunals of commerce is largely due to the solidarity of the commercial interests, foreign and Turkish, and to the con- 
centration of those interests in the few leading ports, where the methods of business are well established. The proportion of Mussulmans to non-Mussulmans, including Greeks, Armenians and foreigners in Constantinople and Smyra is thought to be (accurate statistics do not exist) about seventy-seren Mussulmans to eighty-seven non-Mussulmans. ${ }^{1}$ The proportion of purely Turkish business interests is very small. The prosperity of the Greeks and Armenians contrasts with the lack of enterprise and of thrift of the Turks. The Turk is forced either to be tolcrant or to content himself with less of borrowed prosperity.

Recent statements of the general grounds of relinquishing

juris-

diction
The only basis upon which justice to the foreign residents in Turkey would permit the relinquishment of extraterritorial privileges is that upon which the jurisdiction was withdrawn from Japan. A iocumentary statement of this ground of withdrawal is not to be found in the new treaties with Japan, but an excellent statement of it occurs in Article IV of the treaty of May 22, 1882, between the United States and Korea, as follows:

It is, however, mutually agreed between the high contracting powers, that whenever the King of Chosen shall have so far modified and reformed the statutes and the judicial procedure of his kingdom that, in the judgment of the United States, theJ conform to the laws and course of justice in the United States, the right of extraterritorial jurisdiction over United States cittzens in Chosen shall be abandoned, and thereafter United States citizens. when within the limits of the Kingdom of Chosen, shall be subject to the jurisdiction of the native authorities.

The treaty signed at Shanghai, October 8, 1903, between the United States and China, reads, in Article XV, as follows:

The Government of China having expressed a strong desire to reform its judicial system and to bring it into accord with that of Western nations, the United States agrees to give every assistance to such reform and will also be prepared to relinquish extra-territorial rights when satisfied that the state of the Chinese laws, the arrangements for their administration, and other considerations warrant it in so doing.

'Statesman's Year Book, 1905, p. 1220-1. 
The recodification of the laws of Siam, with incorporation of principles of western law, has been proceeding for a number of years, and it is believed that some definite plan of relinquishing consular jurisdiction is likely to be proposed to the foreign powers in the near future. ${ }^{1}$

Similar provisions were inserted in the British and Japanese treaties with China of September 5, 1902, and October 8,1903 . The Chinese have long desired the abrogation of extraterritoriality, yet their government has undertaken no permanent plan to accomplish it. In a way the problem of building up a national system of law in China may be eompared to the problem which confronted Germany in the recodification of laws necessitated by the unification of the empire, for in China, as in Germany, the laws of the various states or provinces composing the empire will have to be most carefully considered in making the general code intended, at least in part, to supplant the local law; and the relation of the German states to their federal mion was far better defined than is the relation of the provineial governments in China to the imperial government. There is much to be hoped for in the example and influence of Japan, and it is generally belicved that the younger men of China, awakening to the possibilities of their country, are preparing to bring aboit such advancement among the Chinese as took place in Japan toward the end of the nineteenth century.

The Chinese governmental system and administration of justice is described with some minnteness in the dispatches of Minister Denby. The penal code of China is written; the civil and commercial law, though consisting of very few prineiples, has something of the nature of the English common law. The lower courts are held by the district magistrate, who, in addition to his judicial duties in both eivil and criminal cases, is responsible for the good order of his distriet, has soldiers under him, colleets taxes and conducts the

\footnotetext{
1 Dange (formerly legal adviser to the government of Slam), De la condition juridique des etrangers et de l'organisation judiciaire au Siam, Jour. du droit internat. privé, 1900, p. 461, 704.
} 
literary or civil service examinations. There are no professional lawyers, but there is an official, with duties in general like those of a constable, who prepares the papers in actions of whatever nature. The court does not appear to be bound by any technical rules, and the decisions would be regarded by an occidental as strangely summary and at times arbitrary. A system of appeals exists, by which cases may be brought before the provincial governors and to the imperial officers at Peking. The fundamental principle in the administration of justice, as in other departments of the government, is that of submission to parental authority. The body of the people take great pride in their existing law, and their influence upon its administration is not unlike the force of public opinion under a democratic form of government. ${ }^{1}$

Rolinquishment is generally simultaneous on the part of the lead ing powers

The treaties which contain provisions as to relinquishment of jurisdiction, it is to be noted, do not mention the possibility of delaying such relinquishment until other powers are prepared to do the same. Although relinquishment in Japan was simultaneous on the part of the powers, except France, it was not approximately of the same time, and there was no coöperation to make it so, in Madagascar and Servia. By treaty of October 30, 1888, Mexico accepted for Mexican citizens in Japan the full jurisdiction of the Japanese government; but although this treaty went into operation more than ten years before the treaties with other western states, it had less significance, because it was the first treaty between the two countries and Mexican citizens had at no time enjoyed extraterritorial privileges in Japan. ${ }^{2}$ But by mutual agreement between Japan and Hawaii the extraterritoriality of Hawaiians in Japan under the treaty of August 19, 1871, was relinquished and announcement thereof made by Japan on April 12, 1894. ${ }^{3}$ China relinquished jurisdiction in Japan by treaty of July 21, 1896. Servia and Turkey mutually renounced it each in the terri-

For. Rel. 1887, p. 212-8; 1888, pt. 1, p. 346.

- Martens, Nouveau receuil, 2d series, (Stoerk), vol. 18, p. 755.

- Parliamentary Papers, 1894, vol. xcvi, Japan No. 1, p. 142. 
tory of the other by convention of March 9, 1896. From these instances of relinquishment it is seen that the practice in regard to abrogation of the more important treaties of extraterritoriality has been to abrogate them at approximately the same time. In a sense the consular courts are like national institutions in the countries where they exist, that is, they have features of jurisdiction and usage peculiar to the localities where they are held, and new difficulties would arise if one western power, acting independently of other powers, should relinquish its share in these institutions. It is conceivable that such independen action might be taken by certain powers with regard to countries where very few of their citizens or subjects might be affected by the change, but independent action by one of the leading powers with regard to China or Turkey is altogether improbable.

In explaining the necessity of consular extraterritorial jurisdiction in the middle of the nineteenth century, when so large a number of treaties providing for it were made, the treaties frequently employed the terms 'non-Christian,' 'semi-civilized,' and 'barbarous,' in relation to oriental states; and the language of official documents of oriental governments contained similar expressions in regard to the western nations. The present infrequency or disappearance of those terms indicates how great has been the change within oriental countries and how much less vague our knowledge of the possible developments among oriental peoples has become. Fifty years ago we knew little of Turkey, except upper Egypt, Constantinople, Smyrna and a few other coast cities; and of the Far East we knew nothing except of methods of trade at a few widely separated ports. Today, with the telegraph and railroad reaching far into the interior of these countries, we are aware that a new era of most remarkable development of the oriental nations has opened. The civilization of the East, though extremely different from that of the West, may no longer be regarded as incompatible with the full international responsibility of

Improved administration of consular courts contributes to national progress in the Orient 
an oriental state to protect the property and lives of foreigners residing or trading in its territory.

If the inadequency of native jurisdiction in the Orient originally made it necessary to establish consular courts and secure extraterritorial privileges, it especially behooves the western states at this time of more rapid development among eastern nations to provide that their jurisdiction in the consular courts be well and justly exercised. The most highly perfected systems of consular jurisdiction, those of Great Britain and France, have been frequently the subject of readjustment and improvement either through legislative action or under regulations provided by the chief counsellors of state. Notwithstanding the extensive eommerce and the large influence which the United States has come to enjoy in the Orient, the system of American consular courts has remained practically without the attention of Congress since 1848. In the interest of justice to American citizens in those countries where the jurisdiction is not likely to be relinquished for years to come, and with the object of maintaining a high standard in our international relations, it is apparently necessary for the government of the United States to provide an improved system of consular extraterritorial jurisdiction. 


\title{
APPENDIX
}

\section{I-EXTRATERRITORIAL STIPULATIONS OF UNITED STATES TREATIES ${ }^{1}$}

\author{
I - BORNEO
}

Treaty of June 23, 1850

Article IX. His Highness the Sultan of Borneo agrees that in all cases where a citizen of the United States shall be accused of any crime committed in any port of His Highness' dominions, the person so accused shall be exclusively tried and adjudged by the American Consul, or other officer duly apopinted for that purpose; and in all cases where disputes or differences may arise between American citizens, or between American citizens and the subjects of His Highness, or between American citizens and the citizens or subjects of any other foreign power in the dominions of the Sultan of Borneo, the American Consul, or other duly appointed officer, shall have power to hear and decide the same, without any interference, molestation or hindrance on the part of any authority of Borneo, either before, during, or after the litigation.

$$
\text { II - CHINA }
$$

\section{Treaty of July 3,1844}

Article XXI. Subjects of China who may be guilty of any criminal act towards citizens of the United States shall be arrested and punished by the Chinese authorities according to the laws of China; and citizens of the United States who may commit any crime in China shall be subject to be tried and punished only by the Consul, or other public functionary of the United States, thereto authorized, according to the laws of the United States. And in order to the prevention of all

1 The treaties from which these extracts are taken were presumably in force January 1, 1906. 
controversy and disaffection, justice shall be equitably and impartially administered on both sides.

Article XXIV. . . . And if controversies arise between citizens of the United States and sul,jects of China, which cannot be amicably settled otherwise, the same shall be examined and decided conformably to justice and equity by the public officers of the two nations acting in conjunction.

Article XXV. All questions in regard to rights, whether of property or person, arising between citizens of the United States in China, shall be subject to the jurisdiction of, and regulated by the authorities of their own Government. And all controversies occurring in China between citizens of the United States and the subjects of any other Government shall be regulated by the treaties existing between the United States and such Governments, respectively, without interference on the part of China.

Article XXIX. . . . The merchants, seamen and other citizens of the United States shall be under the superintendence of the appropriate officers of their Government. If individuals of either nation commit acts of violence or disorder, use arms to the injury of others, or create disturbances endangering life, the officers of the two Governments will exert themselves to enforce order, and to maintain the public peace, by doing impartial justice in the premises.

\section{Treaty of June 18, 1858}

Article XI. All citizens of the United States of America in China, peaceably attending to their affairs, being placed on a common footing of amity and good will with the subjects of China, shall receive and enjoy for themselves and everything pertaining to them, the protection of the local authorities of Government, who shall defend them from all insult or injury of any sort. If their dwellings or property be threatened or attaclied by mobs, incendiaries, or other violent or lawless persons, the local officers, on requisition of the Consul, shall immediately despatch a military force to disperse the rioters, apprehend the guilty individuals, and punish them with the utmost rigor of the law. Subjects of China guilty of any criminal act toward citizens of the United States shall be punished by the Chinese authorities according to laws of China; and citizens of the United States, either on shore or in any merchant vessel, who may insult, trouble or wound the persons or injure the property of Chinese, or commit any other improper act in China, shall be punished only by the Consul or other public functionary thereto authorized, according to the laws of the United States. 
Arrests in order to trial may be made by either the Chinese or the United States authorities.

Article XXVII. . . . All questions in regard to rights, whether of property or of person, arising between citizens of the United States in China shall be subject to the jurisdiction and regulated by the authorities of their own Government; and all controversies occurring in China between citizens of the United States and the subjects of any other Government shall be regulated by the treaties existing between the United States and such Governments, respectively, without interference on the part of China.

\section{Treaty of November 17,1880}

Article IV. When controversies arise in the Chinese Empire between citizens of the United States and subjects of His Imperial Majesty, which need to be examined and decided by the public officers of the two nations, it is agreed between the Governments of the United States and China that such cases shall be tried by the proper official of the nationality of the defendant. The properly authorized official of the plaintiff's nationality shall be freely permitted to attend the trial and shall be treated with the courtesy due to his position. He shall be granted all proper facilities for watching the proceedings in the interests of justice. If he so desires, he shall have the right to present, to examine and to cross-examine witnesses. If he is dissatisfied with the proceedings, he shall be permitted to protest against them in detail. The law administered will be the law of the nationality of the officer trying the case.

\section{III - KOREA}

Treaty of May 22, 1882

Article IV. . . . Subjects of Chosen, guilty of any criminal act towards citizens of the United States, shall be punished by the authorities of Chosen, according to the laws of Chosen; and citizens of the United States, either on shore or in any merchant vessel, who may insult, trouble or wound the persons, or injure the property of the people of Chosen, shall be arrested and punished only by the consul or other public functionary of the United States, thereto authorized according to the laws of the United States.

When controversies arise in the Kingdom of Chosen between citizens of the United States and subjects of His Majesty, which need to be examined and decided by the public officers of the two nations, it is agreed between the two Governments 
of the United States and Chosen, that such cases shall be tried by the proper official of the nationality of the defendant, according to the laws of that nation. The properly authorized ofincial of the plaintiff's nationality shall be freely permitted to attend the trial, and shall be treated with the courtesy due to his position. He shall be granted all proper facilities for watching the proceedings in the interests of justice. If he so desires, he shall have the right to present, to examine and to cross-examine witnesses. If he is dissatisfied with the proceedings, he shall be permitted to protest against them in detail.

It is, however, mutually agreed and understood between the high contracting powers, that whenever the King of Chosen shall have so far modified and reformed the statutes and judicial procedure of his kingdom that, in the judgment of the United States, they conform to the laws and course of justice in the United States, the right of extraterritorial jurisdiction over United States citizens in Chosen shall be abandoned, and thereafter United States citizens, when within the limits of the Kingdom of Chosen, shall be subject to the jurisdiction of the native authorities.

\section{IV - MASKAT}

Treaty of September 21, 1833

Article IX. The President of the United States may appoint consuls to reside in the ports of the Sultan where the principal commerce shall be carried on, which consuls shall be the exclusive judges of all disputes or suits wherein American citizens shall be engaged with each other. They shall have power to receive the property of any American citizen dying within the kingdom, and to send the same to his heirs, first paying all his debts due to the subjects of the Sultan. The said consuls shall not be arrested, nor shall their property be seized, nor shall any of their household be arrested, but their persons and property and their houses shall be inviolate. Should any consul, however, commit any offense against the laws of the kingdom, complaint shall be made to the President, who shall immediately displace him.

\section{V-MOROCCO}

Treaty of January 25,1787

Article XX. If any of the citizens of the United States, or any persons under their protection, shall have any disputes with each other, the Consul shall decide between the parties, 
and whenever the Consul shall require any aid or assistance from our Government, to enforce his decisions, it shall be immediately granted to him.

Article XXI. If a citizen of the United States should kill or wound a Moor, or, on the contrary, if a Moor shall kill or wound a citizen of the United States, the law of the country shall take place, and equal justice shall be rendered, the Consul assisting at the trial; and if any delinquent shall make his escape, the Consul shall not be answerable for him in any manner whatever.

Treaty of September 16, 1836

(Articles XX, XXI are the same as Articles XX, XXI of the treaty of January 25,1787 , supra.)

$$
\text { VI - PERSIA }
$$

Treaty of December 13,1856

Article V. . . . All suits and disputes arising in Persia between Persian subjects and citizens of the United States shall be carried before the Persian tribunal to which such matters are usually referred at the place where a Consul or Agent of the United States may reside, and shall be discussed and decided according to equity, in the presence of an employé of the Consul or Agent of the United States.

All suits and disputes which may arise in the Empire of Persia between citizens of the United States shall be referred entirely for trial and for adjudication to the Consul or Agent of the United States residing in the province wherein such suits and disputes may have arisen, or in the province nearest to it, who shall decide them according to the laws of the United States.

All suits and disputes occurring in Persia between the citizens of the United States and the subjects of other foreign Powers, shall be tried and adjudicated by the intermediation of their respective Consuls or Agents.

In the United States, Persian subjects, in all disputes arising between themselves, or between them and citizens of the United States or foreigners, shall be judged according to the rules adopted in the United States respecting the subjects of the most favored nation.

Persian subjects residing in the United States, and citizens of the United States, residing in Persia, shall, when charged with criminal offences, be tried and judged in Persia and the United States in the same manner as are the subjects and 
citizens of the most favored nation residing in either of the above-mentioned countries.

$$
\text { VII - SIAM }
$$

Treaty of March 20, 1833

Article IX. Merchants of the United States trading in the Kingdom of Siam shall respect and follow the laws and customs of the country in all points.

\section{Treaty of May 29, 1856}

Article II. The interests of all American citizens coming to Siam shall be placed under the regulations and control of a Consul, who will be appointed to reside at Bangkok. He will himself conform to and will enforce the observance by American citizens of all the provisions of this treaty, and such of the former treaty, negotiated by Mr. Edmund Roberts, in 1833, as shall still remain in operation. He shall also give effect to all rules and regulations as are now or may hereafter be enacted for the government of American citizens in Siam, the conduct of their trade, and for the prevention of violation of the laws of Siam. Any dispute arising between American citizens and Siamese subjects shall be heard and determined by the Consul, in conjunction with the proper Siamese officers; and criminal offences will be punished in the case of American offenders, by the Consul, according to American laws, and in the case of Siamese offenders by their own laws, through the Siamese authorities. But the Consul shall not interfere in any matters referring solely to Siamese; neither will the Siamese authorities interfere in questions which only concern the citizens of the United States.

$$
\text { VIII - TRIPOLI }
$$

Treaty of November 4, 1796

Article IX. The commerce between the United States and Tripoli; the protection to be given to merchants, masters of vessels and seamen; the reciprocal right of establishing Consuls in each country, and the privileges, immunities, and jurisdictions to be enjoyed by such Consuls are declared to be on the same footing with those of the most favoured nations respectively.

\section{Treaty of June 4, 1805}

Article XVIII. If any of the citizens of the United States, or any persons under their protection, shall have any dispute 
with each other, the Consul shall decide between the parties, and whenever the Consul shall require any aid or assistance from the Government of Tripoli to enforce his decisions, it shall immediately be granted to him, and if any dispute shall arise between any citizen of the United States and the citizens or subjects of any other nation having a Consul or Agent in Tripoli, such dispute shall be settled by the Consuls or Agents of the respective nations.

Article XIX. If a citizen of the United States should kill or wound a Tripoline, or, on the contrary, if a Tripoline shall kill or wound a citizen of the United States, the law of the country shall take place, and equal justice shall be rendered, the Consul assisting at the trial; and if any delinquent shall make his escape, the Consul shall not be answerable for him in any manner whatever.

\section{IX - TURKEY}

\section{Treaty of May 7,1830}

Article IV. If litigations and disputes should arise between subjects of the Sublime Porte and citizens of the United States. the parties shall not be heard, nor shall judgments be pronounced unless the American Dragoman be present. Causes in which the sum may exceed five hundred piastres, shall be submitted to the Sublime Porte, to be decided according to the laws of equity and justice. Citizens of the United States of America, quietly pursuing their commerce, and not being charged or convicted of any crime or offence, shall not be molested; and even when they may have committed some offence they shall not be arrested and put in prison, by the local anthorities, but they shall be tried by their Minister or Consul, and punished according to their offence, following, in this respect, the usage observed towards other Franks.

\section{$\mathrm{X}-\mathrm{ZANZIBAR}$}

\section{Treaty of July 3,1886}

Article II. The Consuls of the United States appointed under the stipulation of the IXth article of the treaty above mentioned, shall, in addition to the rights, powers and immunities secured by said article, enjoy all the rights, privileges, immunities and jurisdictional powers which are now or may hereafter be enjoyed by the Consuls and Consular Agents of the most favored nations, and, conversely, the Consuls and Consular Agents which His Highness the Sultan may appoint to reside in the United States shall have the treatment of Agents of like grade of the most favored nation. 


\section{II-UNITED STATES REVISED STATUTES, SECTIONS 4083-4130}

SEC. 4083. To carry into full effect the provisions of the treaties of the United States with China, Japan, Siam, Egypt, and Madagascar, respectively, the minister and the consuls of the United States, duly appointed to reside in each of those countries, shall, in addition to other powers and duties imposed upon them, respectively, by the provisions of such treaties, respectively, be invested with the judicial authority herein described, which shall appertain to the office of minister and consul, and be a part of the duties belonging thereto, wherein, and so far as, the same is allowed by treaty.

SEC. 4084. The officers mentiened in the preceding section are fully empowered to arraign and try, in the manner herein provided, all citizens of the United States charged with offenses against law, committed in such countries, respectively, and to sentence such offenders in the manner herein authorized; and each of them is authorized to issue all such processes as are suitable and necessary to carry this authority into execution.

SEC. 4085. Such officers are also invested with all the judicial authority necessary to execute the provisions of such treaties, respectively, in regard to civil rights, whether of property or person; and they shall entertain jurisdiction in matters of contract, at the port where, or nearest to which, the contract was made, or at the port at which, or nearest to which, it was to be executed, and in all other matters, at the port where, or nearest to which, the cause of controversy arose, or at the port where, or nearest to which, the damage complained of was sustained, provided such port be one of the ports at which the United States are represented by consuis. Such jurisdiction shall enbrace all controversies between citizens of the United States, or others, provided for by such treaties, respectively.

SEC. 4086. Jurisdiction in both criminal and civil matters shall, in all cases, be exercised and enforced in conformity with the laws of the United States, which are hereby, so far as is necessary to execute such treaties, respectively, and so far as they are suitable to carry the same into effect, extended over all citizens of the United States in those countries, and over all others to the extent that the terms of the treaties, respectively, justify or require. But in all cases where such laws are not adapted to the object, or are deficient in the provisions neces- 
sary to furnish suitable remedies, the common law and the law of equity and admiralty shall be extended in like manner over such citizens and others in those countries; and if neither the common law, nor the law of equity or admiralty, nor the statutes of the United States, furnish appropriate and sufficient remedies, the ministers in those countries, respectively, shall, by decrees and regulations which shall have the force of law, sup. ply such defects and deficiencies.

SEc. 4087. Each of the consuls mentioned in section forty hundred and eighty-three, at the port for which he is appointed, is authorized upon facts within his own knowledge, or which he has good reason to believe true, or upon complaint made or information filed in writing and authenticated in such way as shall be prescribed by the minister, to issue his warrant for the arrest of any citizen of the United States charged with committing in the country an offense against law; and to arraign and try any such offender; and to sentence him to punishment in the manner herein prescribed.

SEc. 4088. The consuls and commercial agents of the United States at islands or in countries not inhabited by any civilized people, or recognized by any treaty with the United States, are anthorized to try, hear, and determine all cases in regard to civil rights, whether of person or property, where the real debt or damages do not exceed the sum of one thousand dollars, exclusive of costs, and upon full hearing of the allegations and evidence of both parties, to give judgment according to the laws of the United States, and according to the equity and right of the matter, in the same manner as justices of the peace are now authorized and empowered where the United States have exclusive jurisdiction. They are also invested with the powers conferred by the provisions of sections forty hundred and eightysix and forty hundred and eighty-seven for trial of offenses or misdemeanors.

SEC. 4089. Any consul when sitting alone may also decide all cases in which the fine imposed does not exceed five hundred dollars, or the term of imprisonment does not exceed ninety days; but in all such cases, if the fine exceeds one hundred dol lar's, or the term of imprisonment for misdemeanors exceeds sixty days, the defendants or any of them, if there be more than one, may take the case, by appeal, before the minister, if allowed jurisdiction, either upon errors of law or matters of fact, under such rules as may be prescribed by the minister for the prosecution of appeals in such cases.

SEC. 4090. Capital cases for murder or insurrection against the government of either of the countries hereinbefore men. tioned, by citizens of the United States, or for offenses against 
the public peace amounting to felony under the laws of the United States, may be tried before the minister of the United States in the country where the offense is committed if allowed jurisdiction; and every such minister may issue all manner of writs, to prevent the citizens of the United States frem en. listing in the military or naval service of either of the said countries, to make war upon any foreign power with whom the United States are at peace, or in the service of one portion of the people against any other portion of the same people; and he may carry out this power by a resort to such force belonging to the United States, as may at the time be within his reach.

SEc. 4091. Each of the ministers mentioned in section forty hundred and eighty-three shall, in the country to which he is appointed, be fully authorized to hear and decide all cases, criminal and civil, which may come before him, by appeal, under the provisions of this Title, and to issue all processes necessary to execute the power conferred upon him; and he is fully empowered to decide finally any case upon the evidence which comes up with it, or to hear the parties further, if he thinks justice will be promoted thereby; and he may also prescribe the rules upon which new trials may be granted, either by the consuls or by himself, if asked for upon sufficient grounds.

SEc. 4092. On any final judgment in a consular court of China or Japan, where the matter in dispute exceeds five hundred dollars and does not exceed two thousand five hundred dollars, exclusive of costs, an appeal shall be allowed to the minister in such country, as the case may be. But the appellant shall comply with the conditions established by general regulations. And the ministers are hereby authorized and required to receive, hear, and determine such appeals.

SEc. 4093. On any final judgment in any consular court of China or Japan, where the matter in dispute, exclusive of costs, exceeds the sum of two thousand five hundred dollars, an appeal shall be allowed to the circuit court for the district of California, and upon such appeal a transcript of the libel, bill, answer, depositions, and all other proceedings in the cause shall be transmitted to the circuit court, and no new evidence shall be received on the hearing of the appeal; and the appeal shall be subject to the rules, regulations, and restrictions prescribed in law for writs of error from district courts to circuit courts.

SEC. 4094. On any final judgment of the minister to China, or to Japan, given in the exercise of original jurisdiction, where the matter in dispute, exclusive of costs, exceeds two thousand five hundred dollars, an appeal shall be allowed to the circuit court, as provided in the preceding section.

SEC. 4095. When any final judgment of the minister to 
China, or to Japan, is given in the exercise of original or of appellate criminal jurisdiction, the person charged with the crime or offense, if he considers the judgment erroneous in point of law, may appeal therefrom to the circuit court for the district of California; but such appeal shall not operate as a stay of proceedings, unless the minister certifies that there is probable cause to grant the same, when the stay shall be such as the interests of justice may require.

SEc. 4096. The circuit court for the district of California is authorized and required to receive, hear, and determine the appeals provided for in this Title, and its decisions shall be final.

SEc. 4097. In all cases, criminal and civil, the evidence shall be taken down in writing in open court, under such regulations as may be made for that purpose; and all objections to the competency or character of testimony shall be noted, with the ruling in all such cases, and the evidence shall be part of the case.

SEc. 4098. It shall be the duty of the ministers and the consuls in the countries mentioned in section forty hundred and eightythree, to encourage the settlement of controversies of a civil character, by mutual agreement, or to submit them to the decision of referees agreed upon by the parties; and the minister in each country shall prepare a form of submission for such cases, to be signed by the parties, and acknowledged before the consul. When parties have so agreed to refer, the referees may, after suitable notice of the time and place of meeting for the trial, proceed to hear the case, and a majority of them shall have power to decide the matter. If either party refuses or neglects to appear, the referees may proceed ex parte. After hearing any case such reterees may deliver their award, sealed, to the consul, who, in court, shall open the same; and if he accepts it, he shall indorse the fact, and judgment shall be rendered thereon, and execution issue in compliance with the terms thereof. The parties, however, may always settle the same before return thereof is made to the consul.

SEc. 4099. In all criminal cases which are not of a heinous character, it shall be lawful for the parties aggrieved or concerned therein, with the assent of the minister in the country, or consul, to adjust and settle the same among themselves, upon pecuniary or other considerations.

SEc. 4100 . The ministers and consuls shall be fully authorized to call upon the local authorities to sustain and support them in the execution of the powers confided to them by treaty, and on their part to do and perform whatever is necessary to carry the provisions of the treaties into full effect, so far as they are to be executed in the countries, respectively. 
SEC. 4101. In all cases, except as herein otherwise provided, the punishment of crime provided for by this title shall be by fine or imprisonment, or both, at the discretion of the officer who decides the case, but subject to the regulations herein contained, and such as may hereafter be made. It shall, however, be the duty of such officer to award punishment according to the magnitude and aggravation of the offense. Every person who refuses or neglects to comply with the sentence passed upon him shall stand committed until he does comply, or is discharged by order of the consul, with the consent of the minister in the country.

SEC. 4102. Insurrection or rebellion against the government of either of those countries, with intent to subvert the same, and murder, shall be capital offenses, punishable with death; but no person shall be convicted of either of those crimes, unless the consul and his associates in the trial all concur in opinion, and the minister also approves of the conviction. But it shall be lawful to convict one put upon trial for either of these crimes, of a less offense of a similar character, if the evidence justifies it, and to punish, as for other offenses, by fine or imprisonment, or both.

SEC. 4103. Whenever any person is convicted of either of the crimes punishable with death, in either of those countries, it shall be the duty of the minister to issue his warrant for the execution of the convict, appointing the time, place, and manner; but if the minister is satisfied that the ends of public justice demand it, he may from tine to time postpone such execution; and if he finds mitigating circumstances which authorize it, he may submit the case to the President for pardon.

SEc. 4104. No fine imposed by a consul for a contempt committed in presence of the court, or for failing to obey a summons from the same, shall exceed fifty dollars; nor shall the imprisonment exceed twenty-four hours for the same contempt.

SEc. 4105. Any consul, when sitting alone for the trial of offenses or misdeamors, shall decide finally all cases where the fine imposed does not exceed one hundred dollars, or the term of imprisonment does not exceed sixty days.

SEC. 4106. Whenever, in any case, the consul is of opinion that, by reason of the legal questions which may arise therein, assistance will be useful to him, or whenever he is of opinion that severer punishments than those specified in the preceding sections will be required, he shall summon, to sit with him on the trial, one or more citizens of the United States, not exceeding four, and in capital cases not less than four, who shall be taken by lot from a list which had previously been submitted to and approved by the minister, and shall be persons of good repute 
and competent for the duty. Every such associate shall enter upon the record his judgment and opinion, and shall sign the same; but the consul shall give judgment in the case. If the consul and his associates concur in opinion, the decision shall, in all cases, except of capital offenses and except as provided in the preceding section, be final. If any of the associates differ in opinion from the consul, the case, without further proceedings, together with the evidence and opinions, shall be referred to the minister for his adjudication, either by entering up judgment therein, or by remitting the same to the consul with instructions how to proceed therewith.

SEc. 4107. Each of the consuls mentioned in section four thousand and eighty-three shall have at the port for which he is appointed, jurisdiction as herein provided, in all civil cases arising under such treaties, respectively, wherein the damages demanded do not exceed the sum of five hundred dollars; and, if he sees fit to decide the same without aid, his decision thereon shall be final. But whenever he is of opinion that any such case involves legal perplexities, and that assistance will be useful to him, or whenever the damages demanded exceed five hundred dollars, he shall summon, to sit with him on the hearing of the case, not less than two nor more than three citizens of the United States, if such are residing at the port, who shall be taken from a list which had previously been submitted to and approved by the minister, and shall be of good repute and competent for the duty. Every such associate shall note upon the record his opinion, and also, in case he dissents from the consul, such reasons therefore as he thinks proper to assign; but the consul shall give judgment in the case. If the consul and his associates concur in opinion, the judgment shall be final. If any of the associates differ in opinion from the consul, either party may appeal to the minister, under such regulations as may exist; but if no appeal is lawfully claimed, the decision of the consul shall be final.

SEC. 4108. The jurisdiction allowed by treaty to the ministers, respectively, in the countries named in section four thousand and eighty-three shall be exercised by them in those countries, respectively, wherever they may be.

SEc. 4109. The jurisdiction of such ministers in all matters of civil redress, or of crimes, except in capital cases for murder or insurrection against the governments of such countries, respectively, or for offenses against the public peace amounting to felony under the laws of the United States, shall be appellate only: Prowided, That in cases where a consular officer is interested, either as party or witness, such minister shall have original jurisdiction. 
SEc. 4110. All such officers shall be responsible for their conduct to the United States, and to the laws thereof, not only as diplomatic or consular officers, but as judical officers, when they perform judical duties, and shall be held liable for all negligences and misconduct as public officers.

SEc. 4111. The President is authorized to appoint marshals for such of the consular courts in those countries as he may think proper, not to exceed seven in number, namely: one in Japan, four in China, one in Siam, and one in Turkey, each of whom shall receive a salary of one thousand dollars a year, in addition to the fees allowed by the regulations of the minister's, respectively, in those countries.

SEC. 4112 . It shall be the duty of the marshals, respectively, to execute all process issued by the minister of the United States in those countries, respectively, or by the consul at the port at which they reside, and to make due return thereof to the officer by whom it was issued, and to conform in all respects to the regulations prescribed by the ministers, respectively, in regard to their duties.

SEc. 4113. Each marshal, before entering upon the duties of his office, shall give bond for the faithful performance thereof in a penal sum not to exceed ten thousand dollars, with two sureties to be approved by the Secretary of State. Such bond shall be transmitted to the Secretary of the Treasury, and a certified copy thereof be lodged in the office of the minister.

SEC. 4114. Whenever any person desires to bring suit upon the bond of any such marshal, it shall be the duty of the Secretary of the Treasury, or of the minister having custody of a copy of the same, to give to the person so applying a certified copy thereof, upon which suit may be brought and prosecuted with the same effect as could be done upon the original: Provided, The Secretary of the Treasury, or the minister to whom the application is made, is satisfied that there is probable cause of action against the marshal.

SEC. 4115. Upon a plea of non est factum, verified upon oath, or any other good cause shown, the court or the consul or minister trying the cause may require the original bond of the marshal in those countries to be produced; and it shall be the duty of the Secretary of the Treasury to forward the original bond to the court, or consul, or minister requiring the same.

SEC. 4116. All rules, orders, writs, and processes of every kind which are intended to operate or be enforced against any of the marshals, in any of the countries named in this Title, shall be directed to and executed by such persons as may be appointed for that purpose by the minister of consul issuing the same. 
SEC. 4117. In order to organize and carry into effect the system of jurisprudence demanded by such treaties, respectively, the ministers, with the advice of the several consuls in each of the countries, respectively, or of so many of them as can be conveniently assembled, shall prescribe the forms of all processes to be issued by any of the consuls; the mode of executing and the time of returning the same; the manner in which trials shall be conducted, and how the records thereof shall be kept; the form of oaths for Christian witnesses, and the mode of examining all other witnesses; the costs to be allowed to the prevailing party, and the fees to be paid for judicial services; the manner in which all officers and agents to execute process, and to carry this Title into effect, shall be appointed and compensated; the form of bail-bonds, and the security which shall be required of the party who appeals from the decision of a consul; and shall make all such further decrees and regulations from time to time, under the provisions of this Title, as the exigency may demand.

SEc. 4118. All such regulations, decrees, and orders shall be plainly drawn up in writing, and submitted, as hereinbefore provided, tor the advice of the consuls, or as many of them as can be consulted without prejudicial delay or inconvenience, and such consul shall signify his assent or dissent in writing, with his name subscribed thereto. After taking such advice, and considering the same, the minister in each of those countries may, nevertheless, by causing the decree, order, or regulation to be published with his signature thereto, and the opinions of his advisers inscribed thereon, make it binding and obligatory, until annulled or modified by Congress; and it shall take effect from the publication or any subsequent day thereto named in the act.

SEc. 4119. All such regulations, orders, and decrees shall, as speedily as may be after publication, be transmitted by the ministers, with the opinions of their advisers, as drawn up by them severally, to the Secretary of State, to be laid before Congress for revision.

SEC. 4120. It shall be the duty of the minister in each of those countries to establish a tariff of fees for judicial services, which shall be paid by such parties, and to such persons, as the minister shall direct; and the proceeds shall, as far as is necessary, be applied to defray the expenses incident to the execution of this Title; and regular accounts, both of receipts and expenditures, shall be kept by the minister and consuls and transmitted annually to the Secretary of State.

SEc. 4121. The President, when provision is not otherwise made, is authorized to allow, in the adjustment of the accounts 
of each of the ministers or consuls, the actual expenses of the rent of suitable buildings or parts of buildings to be used as prisons for American convicts in those countries, not to exceed in any case the rate of six hundred dollars a year; and also the wages of the keepers of the same, and for the care of offenders, not to exceed, in any case, the sum of eight hundred dollar's per annum. But no more than one prison shall be hired in Japan, four in China, one in Turkey, and one in Siam, at such port or ports as the minister, with the sanction of the President, may designate, and the entire expense of prison and prison-keepers at the consulate of Bangkok, in Siam, shall not exceed the sum of one thousand dollars a year.

SEC. 4122. The President is authorized to allow, in the adjustment of the accounts of the consul-general at Shanghai, the actual expense of the rent of a suitable building, to be used as a prison for American convicts in China, not to exceed one thousand five hundred dollars a year; and also the wages of the keepers of the same, and for the care of offenders, not to exceed five thousand dollars a year; and to allow, in the adjustment of the accounts of the consuls at other ports in China, the actual expense of the hire of constables and the care of offenders, not to exceed in all five thousand dollars a year.

SEc, 4123. The President is hereby authorized to allow, in the adjustment of the accounts of the consul at Kanagawa, the actual expense of the rent of a suitable building, to be used as a prison for American convicts in Japan, and not to exceed seven hundred and fifty dollars a year; and also the wages of the keepers of the same, and for the care of offenders, not to exceed two thousand five hundred dollars a year; and to allow in the adjustment of the accounts of the consuls at other ports in Japan the actual expense of the hire of constables and the care of offenders, not to exceed in all two thousand five hundred dollars a year.

SEc. 4124. The Secretary of State, through the minister resident at Japan, is authorized to rent, furnish, and keep suitable buildings, with grounds appurtenant, in Jeddo, or such other place as he may designate, for a court-house and jail, at an annual cost not exceeding five thousand dollars: Provided, That the period for which the buildings shall be rented shall be for two years, with renewals for two years, as the Secretary of State may determine.

SEC. 4125. The provisions of this Title, as far as the same relate to crimes and offenses committed by citizens of the United States, shall extend to Turkey, under the treaty with the Sublime Porte of May seventh, eighteen hundred and thirty, and shall be executed in the Ottoman dominions in conformity with 
the provisions of the treaty, and of this Title, by the minister and the consuls appointed to reside therein, who are hereby ex officio vested with the powers herein conferred upon the ministers and consuls in China, for the purposes above ex. pressed, so far as regards the punishment of crime, and also cor the exercise of jurisdiction in civil cases wherein the same is permitted by the laws of Turkey, or its usages in its intercourse with the Franks, or other foreign Christian nations.

SEc. 4126. The provisions of this Title shall extend to Persia, in respect to all suits and disputes which may arise between citizens of the United States therein; and the minister and consuls who may be appointed to reside in Persia are hereby invested, in relation to such suits and disputes, with such powers as are by this Title conferred upon the ministers and consuls in China. All suits and disputes arising in Persia between Persian subjects and citizens of the United States shall be carried before the Persian tribunal to which such matters are usually referred, at the place where a consul or agent of the United States may reside, and shall be discussed and decided according to equity, in the presence of an employé of the consul or agent of the United States; and it shall be the duty of the consular officer to attend the trial in person, and see that justice is administered. All suits and disputes occurring in Persia between the citizens of the United States and the subjects of other foreign powers, shall be tried and adjudicated by the intermediation of their respective ministers or consuls, in accordance with such regulations as shall be mutually agreed upon by the minister of the United States for the time being, and the ninisters of such foreign powers, respectively, which regulations shall from time to time be submitted to the Secretary of State.

SEC. 4127. The provisions of this Title, so far as the same are in conformity with the stipulations in existing treaties between the United States and Tripoli, Tunis, Morocco, Muscat, and the Samoan or Navigator Islands, respectively, shall extend to those countries, and shall be executed in conformity with the provisions of the treaties and of the movisions of this Title by the consuls appointed by the United States to reside therein, who are hereby ex officio invested with the powers herein delegated to the ministers and consuls of the United States appointed to reside in the countries named in section four thousand and eighty-three, so far as the same can be exercised under the provisions of treaties between the United States and the several countries mentioned in this section, and in accordance with the usages of the countries in their intercourse with the Franlis or other foreign Christian nations. 
And whenever the United States shall negotiate a treaty with any foreign government, in which the American consulgeneral or consul shall be clothed with judicial authority, and securing the right of trial to American citizens residing therein before such consul-general or consul, and containing provisions similar to or like those contained in the treaties with the governments named in this act, then said title, so far as the same may be applicable, shall have full force in reference to said treaty, and shall extend to the country of the government negotiating the same. [As amended by act of June 14, 1878, 20 Stat., 131.]

SEC. 4128. If at any time there be no minister in either or the countries hereinbefore mentioned, the judicial duties which are imposed by this Title upon the minister shall devolve upon the Secretary of State, who is authorized and required to dis. charge the same.

SEC. 4129. The provisions of this Title relating to the jurisdiction of consular and diplomatic officers over civil and crim. inal cases in the countries therein named, shall extend to any country of like character with which the United States may hereafter enter into treaty relations.

SEC. 4130. The word "minister," when used in this Title shall be understood to mean the person invested with, and exercising, the principal diplomatic functions. The word "consul" shall be understood to mean any person invested by the United States with, and exercising, the functions of consul-general, vice consul-general, consul or vice-consul. 


\section{III-1-REORGANIZATION OF THE CONSULAR SERVICE, ACT OF APRIL 5, 1906}

An Act To provide for the reorganization of the consular service of the United States.

$B \mathcal{c}$ it cuacted by the Scnate and House of Representatives of the United States of Amcrica in Congress asscmbled, That the consular system of the United States be reorganized in the manner hereinafter provided in this Act.

SEc. 2. That the consuls-general and the consuls of the United States shall hereafter be classified and graded as hereinafter specified, with the salaries of each class herein affixed theretc.

\section{CONSULS-GENERAL.}

Class one, twelve thousand dollars.-London, Paris.

Class two, eight thousand dollars.-Berlin, Habana, Hongkong, Hamburg, Rio de Janeiro, Shanghai.

Class three, six thousand dollars.-Calcutta, Cape Town, Constantinople, Mexico City, Montreal, Ottawa, Vienna, Yokohama.

Class four, five thousand five hundred dollars.-Antwerp, Barcelona, Brussels, Canton, Frankfort, Marseilles, Melbourne, Panama, Saint Petersburg, Seoul, Tientsin.

Class five, four thousand five hundred dollars.-Auckland, Beirut, Buenos Ayres, Callao, Chefoo, Coburg, Dresden, Guayaquil, Halifax, Hankau, Mukden, Munich, Niuchwang, Rome, Rotterdam, Saint Gall, Singapore.

Class six, three thousand five hundred dollars.-Adis Ababa, Bogota, Budapest, Guatemala, Lisbon, Monterey, San Salvador, Stockholm, Tangier.

Class seven, three thousand dollars.-Athens, Christiania, Copenhagen.

\section{CONSULS.}

Class one, eight thousand dollars.-Liverpool

Class two, six thousand dollars.-Manchester.

Class three, five thousand dollars.-Bremen, Dawson, Belfast, Havre, Kobe, Lourenço Marquez, Lyon, Pretoria.

Class four, four thousand five hundred dollars.-Amoy, Amsterdam, Birmingham, Cienfuegos, Fuchau, Glasgow, Kingston (Jamaica), Nottingham, Santiago, Southampton, Veracruz, Valparaiso. 
Class five, four thousand dollars.-Bahia, Bombay, Bordeaux, Colon, Dublin, Dundee, Harbin, Leipzig, Nanking, Naples, Nuremberg, Para, Pernambuco, Plauen, Reichenberg, Santos, Stuttgart, Toronto, Tsingtau, Vancouver, Victoria.

Class six, three thousand five hundred dollars.-Apia, Barmen, Barranquilla, Basel, Berne, Bradford, Chemnitz, Chungking, Cologne, Dalny, Durban, Edinburgh, Geneva, Genoa, Georgetown, Lucerne, Mannheim, Montevideo, Nagasaki, Odessa, Palermo, Port Elizabeth, Prague, Quebec, Rimouski, San Juan del Norte, Sherbrooke, Smyrna, Three Rivers (Quebec), Vladivostok, Winnipes, Zurich.

Class seven, three thousand dollars._Aix la Chapelle, Annaberg, Barbados, Batavia, Burslem, Calais, Carlsbad, Colombo, Dunfermline, Dusseldorf, Florence, Freiburg, Ghent, Hamilton (Ontario), Hanover, Harput, Huddersfield, Iquitos, Jerusalem, Kehl, La Guaira, Leghorn, Liege, Mainz, Malaga, Managua, Nantes, Nassau, Newcastle (New South Wales), Newcastle (England), Port Antonio, Port au Prince, Sandakan, Seville, Saint Joln (New Brunswick), Saint Michaels, Saint Thomas (West Indies), San Jose, Sheffield, Swansea, Sydney (Nova Scotia), Syciney (New South Wales), Tabriz, Tampico, Tamsui, Trieste, Trinida!!

Class eight, two thousand five hundred dollars.-Acapulco, Aden, Algiers, Alexandretta, Banuerg, Batum, Belize, Bergen, Breslau, Brunswick, Cardiff, Chihuahua, Ciudad Juarez, Ciudad Porfirio Diaz, Collingwood, Cork, Crefeld, Curacao, Eibenstock, Gothenburg, Hamilton (Bermuda), Hull, Jerez de la Frontera, La Rochelle, Leeds, Madrid, Magdeburg, Malta, Maracaibo, Martinique, Matamoros, Mazatlan, Milan, Moscow, Nice, Nogales, Nuevo Laredo, Orillia, Plymouth, Port Hope, Port Limon, Prescott, Puerto Cortez, Rheims, Rosario, Roubaix, Saint Johns (Newfoundland, Saint Etienne, Sarnia, Sault Sainte Marie, Stettin, Tamatave, Tegucigalpa, Teneriffe, Trebizond, Valencia, Weimar, Windsor (Ontario), Yarmouth, Zanzibar, Zittau.

Class nine, two thousand dollars.-Aguascalientes, Antigua, Asuncion, Bagdad, Belleville, Belgrade, Bristol, Campbellton, Cape Gracias, Cape Haitien, Cartagena, Castellamare di Stabia, Catania, Ceiba, Charlottetown, Coaticook, Cornwall, Durango, Ensenada, Fort Erie, Funchal, Gaspe, Gibraltar, Glauchau, GoreeDakar, Grenoble, Guadeloupe, Hermosillo, Hobart, Iquique, Jalapa, Jamestown, Kingston (Ontario), La Paz, Limoges, Manzanillo, Maskat, Messina, Moncton, Niagara Falls, Patras, Port Louis, Port Rowan, Port Stanley, Progreso, Puerto Cabello, Puerto Plata, Riga, Rouen, Saigon, Saint Christopher, Saint Hyacinthe, Saint Johns (Quebec), Saint Pierre, Saint Stephen, Saltillo, Sierra Leone, Sivas, Stavanger, Sura, Tahiti, Turin, • 
Turks Island, Tuxpam, Utilla, Venice, Warsaw, Windsor (Nova Scotia), Woodstock.

SEc. 3. That the offices of vice-consuls-general, deputy consuls-general, vice-consuls, and deputy consuls shall be filled by appointment, as heretofore, except that whenerer, in his judgment, the good of the service requires it, consuls may be designated by the President without thereby changing their classification to act for a period not to exceed one year as vice-consulsgeneral, deputy consuls-general, vice-consuls, and deputy consuls; and when so acting they shall not be deemed to have vacated their offices as consuls. Consular agents may be appointed, when necessary, as heretofore. The grade of commercial agent is abolished.

SEc. 4. That there shall be five inspectors of consulates, to be designated and commissioned as consuls-general at large, who shall receive an annual salary of five thousand dollars each, and shall be paid their actual and necessary traveling and subsistence expenses while traveling and inspecting under instructions from the Secretary of State. They shall be appointed by the President, with the advice and consent of the Senate, from the members of the consular force possessing the requisite qualifications of experience and ability. They shall make such inspections of consular offices as the Secretary of State shall direct, and shall report to him. Each consular office shall be inspected at least once in every two years. Whenever the President has reason to believe that the business of a consulate or a consulate-general is not being properly conducted and that it is necessary for the public interest, he may authorize any consul-general at large to suspend the consul, or consul-general, and administer the office in his stead for a period not exceeding ninety days. In such case the consul-general at large so authorized shall have power to suspend any vice or deputy consular officer or clerk in said office during the period aforesaid. The provisions of law relating to the official bonds of consuls-general, and the provisions of sections seventeen hundred and thirty-four, seventeen hundred and thirty-five, and seventeen hundred and thirty-six, Revised Statutes of the United States, shall apply to consuls-general at large.

SEc. 5. No person who is not an American citizen shall be appointed hereafter in any consulate-general or consulate to any clerical position the salary of which is one thousand dollars a year or morc.

SEc. 6. Sections sixteen hundred and ninety-nine and seventeen hundred of the Revised Statutes of the United States are hereby amended to read as follows:

"SEc. 1699. No consul-general, consul, or consular agent 
receiving a salary of more than one thousand dollars a year shall, while he holds his office, be interested in or transact any business as a merchant, factor, broker, or other trader, or as a clerk or other agent for any such person to, from, or within the port, place, or limits of his jurisdiction, directly or indirectly, either in his own name or in the name or through the agency of any other person; nor shall he practice as a lawyer for compensation or be interested in the fees or compensation of any lawyer; and he shall in his official bond stipulate as a condition thereof not to violate this prohibition.

"SEC. 1700. All consular officer's whose respective salaries exceed one thousand dollars a year shall be subject to the prohibition against transacting business, practicing as a lawyer, or being interested in the fees or compensation of any lawyer contained in the preceding section. And the President may extend the prohibition to any consul-general, consul, or consular agent whose salary does not exceed one thousand dollars a year or who may be compensated by fees, and to any vice or deputy consular officer or consular agent, and may require such officer to give a bond not to violate the prohibition."

Sec. 7. That every consular officer of the United States is hereby required, whenever application is made to him therefor, within the limits of his consulate, to administer to or take from any person any oath, affirmation, affidavit, or deposition, and to perform any other notarial act which any notary public is required or anthorized by law to do within the United States; and for every such notarial act performed he shall charge in each instance the appropriate fee prescribed by the President under section seventeen hundred and forty-five, Revised Statutes.

SEc. 8. That all fees, official or unofficial, received by any officer in the consular service for services rendered in connection with the duties of his office or as a consular officer, including fees for notarial services, and fees for taking depositions, executing commissions or letters rogatory, settling estates, receiving or paying out moneys, caring for or disposing of property, shall be accounted for and paid into the Treasury of the United States, and the sole and only compensation of such officers shall be by salaries fixed by law; but this shall not apply to consular agents, who shall be paid by one half of the fees received in their offices, up to a maximum sum of one thousand dollars in any one year, the other half being accounted for and paid into the Treasury of the United States. And vice-consuls-general, deputy consulsgeneral, vice-consuls, and deputy consuls, in addition to such compensation as they may be entitled to receive as consuls or clerks, may receive such portion of the salaries of the consul- 
general or consuls for whom they act as shall be provided by regulation.

SEo. 9. That fees for the consular certification of invoices shall be, and they hereby are, included with the fees for official services for which the President is authorized by section seventeen hundred and forty-five of the Revised Statutes to prescribe rates or tariffs; and sections twenty-eight hundred and fifty-one and seventeen hundred and twenty-one of the Revised Statutes are hereby repealed.

SEC. 10. That every consular officer shall be provided and kept supplied with adhesive official stamps, on which shall be printed the equivalent money value of denominations and to amounts to be determined by the Department of State, and shall account quarterly to the Department of State for the use of such stamps and for such of them as shall remain in his hands.

Whenever a consular officer is required or finds it necessary to perform any consular or notarial act he shall prepare and deliver to the party or parties at whose instance such act is performed a suitable and appropriate document as prescribed in the consular regulations and affix thereto and duly cancel an adhesive stamp or stamps of the denomination or denominations equivalent to the fee prescribed for such consular or notarial act, and no such act shall be legally valid within the jurisdiction of the Government of the United States unless such stamp or stamps is or are affixed and canceled.

SEc. 11. That this Act shall take effect on the thirtieth day of June, nineteen hundred and six.

SEc. 12. That all Acts or parts of Acts inconsistent with this Act are hereby repealed.

Approved, April 5, 1906.

\section{III-2 - UNITED STATES COURT FOR CHINA, ACT OF JUNE 30,1906}

An Act Creating a United States court for China and prescribing the jurisdiction thereof.

$B_{\mathcal{C}}$ it cllacted by the Scnate and House of Representatizes of the Unitid States of Ancrica in Congress asscmbled, That a court is hereby established, to be called the United States court for China, which shall have exclusive jurisdiction in all cases and judicial proceedings whereof jurisdiction may now be exercised by United States consuls and ministers by law and by virtue of treaties between the United States and China, except in so far 
as the said jurisdiction is qualified by section two of this Act. The said court shall hold sessions at Shanghai, China, and shall also hold sessions at the cities of Canton, Tientsin, and Hankau at stated periods, the dates of such sessions at each city to be announced in such manner as the court shall direct, and a session of the court shall be held in each of these cities at least once annually. It shall be within the power of the judge, upon due notice to the parties in litigation, to open and hold court for the hearing of a special cause at any place permitted by the treaties, and where there is a United States consulate, when, in his judgmeut, it shall be required by the convenience of wituesses, or by some public interest. The place of sitting of the court shall be in the United States consulate at each of the cities, respectively.

That the seal of the said United States court for China shall be the arms of the United States, engraved on a circular piece of steel of the size of a half dollar, with these words on the margin, "The Seal of the United States Court for China."

The seal of said court shall be provided at the expense of the United States.

All writs and processes issuing from the said court, and all transcripts, records, copies, jurats, acknowledgments, and other papers requiring certification or to be under seal, may be authenticated by said seal, and shall be signed by the clerk of said court. All processes issued from the said court shall bear test from the day of such issue.

SEc. 2. The consuls of the United States in the cities of Chind to which they are respectively accredited shall have the same jurisdiction as they now possess in civil cases where the sum or value of the property involved in the controversy does not exceed five hundred dollars United States money and in criminal cases where the punishment for the offense charged can not exceed by law one hundred dollars fine or sixty days' imprisonment, ol both, and shall have power to arrest, examine, and discharge accused persons or commit them to the sald court. From all final judgments of the consular court either party shall have the right of appeal to the United States court for China: Provided, also, That appeal may be taken to the United States court for China from any final judgment of the consular courts of the United States in Korea so long as the rights of extraterritoriality shall obtain in favor of the United States. The said United States court for China shall have and exercise supervisory control over the discharge by consuls and vice-consuls of the duties prescribed by the laws of the United States relating to the estates of decedents in China. Within sixty days after the death in China of any citizen of the United States, or any citizen of any territory belonging to the United States, the consul or vice-consul 
whose duty it becomes to take possession of the effects of such deceased person under the laws of the United States shall file with the clerk of said court a sworn inventory of such effects, and shall as additional effects come from time to time into his possession immediately file a supplemental inventory or inventories of the same. He shall also file with the clerk of said court within sixty days a schedule under oath of the debts of said decedent, so far as known, and a schedule or statement of all additional debts thereaftel discovered. Such consul or viceconsul shall pay no claims against the estate without the written approval of the judge of said court, nor shall he make sale of any of the assets of said estate without first reporting the same to said judge and obtaining a written approval of said sale, and he shall likewise within ten days after any such sale report the fact of such sale to said court, and the amount derived therefrom. The said judge shall have power to require at any time reports from consuls or vice-consuls in respect of all their acts and doings relating to the estate of any such deceased person. The said court shall have power to require where it may be necessary a special bond for the faithful performance of his duty to be given by any consul or vice-consul into whose possession the estate of any such deceased citizen shall have come in such amount and with such sureties as may be deemed necessary, and for failure to give such bond when required, or for failure to properly perform his duties in the premises, the court may appoint some other person to take charge of said estate, such person having first given bond as aforesaid. A record shall be kept by the clerk of said court of all proceedings in respect of any such estate uncler the provisions hereof.

SEC. 3. That appeals shall lie from all final judgments or decrees of said court to the United States circuit court of appeals of the ninth judicial circuit, and thence appeals and writs of error may be taken from the judgments or decrees of the said circuit court of appeals to the Supreme Court of the United States in the same class of cases as those in which appeals and writs of error are permitted to judgments of said court of appeals in cases coming from district and circuit courts of the United States. Said appeals or writs of error shall be regulated by the procedure governing appeals within the United States from the district courts to the circuit courts of appeal, and from the circuit courts of appeal to the Supreme Court of the United States, respectively, so far as the same shall be applicable; and said courts are hereby empowered to hear and determine appeals and writs of error so taken.

SEc. 4. The jurisdiction of said United States court, both original and on appeal, in civil and criminal matters, and also 
the jurisdiction of the consular courts in China, shall in all cases be exercised in conformity with said treaties and the laws of the United States now in force in reference to the American consular courts in China, and all judgments and decisions of said consular courts, and all decisions, judgments, and decrees of said United States court, shall be enforced in accordance with said treaties and laws. But in all such cases when such laws are deficient in the provisions necessary to give jurisdiction or to furnish suitable remedies, the common law and the law as established by the decisions of the courts of the United States shall be applied by said court in its decisions and shall govern the same subject to the terms of any treaties between the United States and China.

SEc. 5. That the procedure of the said court shall be in accordance, so far as practicable, with the existing procedure prescribed for consular courts in China in accordance with the Revised Statutes of the United States: Provided, how'crer, That the judge of the said United States court for China shall have authority from time to time to modify and supplement said rules of procedure. The provisions of sections forty-one hundred and six and forty-one hundred and seven of the Revised Statutes of the United States allowing consuls in certain cases to summon associates shall have no application to said court.

SEC. 6. There shall be a district attorney, a marshal, and a clerk of said court, with authority possessed by the corresponding officers of the district courts in the United States as far as may be consistent with the conditions of the laws of the United States and said treaties. The judge of said court and the district attorney, who shall be lawyers of good standing and experience, marshal, and clerk shall be appointed by the President, by and with the advice and consent of the Senate, and shall receive as salary, respectively, the sums of eight thousand dollars per annum for said judge, four thousand dollars per annum for said district attorney, three thousand dollars per annum for said marshal, and three thousand dollars per annum for said clerk. The judge of the said court and the district attorney shall, when the sessions of the court are held at other cities than Shanghai, receive in addition to their salaries their necessary expenses during such sessions not to exceed ten dollars per day for the judge and five dollars per day for the district attorney.

SEC. 7. The tenure of office of the judge of said court shall be ten years, unless sooner removed by the President for cause; the tenure of office of the other officials of the court shall be at the pleasure of the President.

SEc. 8. The marshal and the clerk of said court shall be required to furnish bond for the faithful performance of their duties, in sums and with sureties to be fixed and approved by the 
judge of the court. They shall each appoint, with the written approval of said judge, deputies at Canton and Tientsin, who shall also be required to furnish bonds for the faithful perform. ance of their duties, which bonds shall be subject, both as to form and sufficiency of the sureties, to the approval of said judge. Such deputies shall receive compensation at the rate of five dollars for each day the sessions of the court are held at their respective cities. The office of marshal in China now existing in pursuance of section forty-one hundred and eleven of the Revised Statutes is hereby abolished.

SEc. 9. The tariff of fees of said officers of the court shall be the same as the tariff already fixed for the consular courts in China, subject to amendment from time to time by order of the President, and all fees taxed and received shall be paid into the Treasury of the United States.

Approved, June 30, 1936.

III-3-EXECUTIVE ORDER, JUNE 27, 1906, CONSULAR SERVICE, REGULATIONS GOVERNING APPOINTMENTS AND PROMOTIONS

Whereas, The Congress, by Section 1753 of the Revised Statutes of the United States has provided as follows:-

"The President is authorized to prescribe such regulations for the admission of persons into the civil service of the United States as may best promote the efficiency thereof, and ascertain the fitness of each candidate in respect to age, health, character, knowledge, and ability for the branch of service into which he seeks to enter; and for this purpose he may employ suitable persons to conduct such inquiries, and may prescribe their duties, and establish regulations for the conduct of persons who may receive appointments in the civil service."

And, whereas, the Congress has classified and graded the consuls-general and consuls of the United States by the act entitled "An act to provide for the reorganization of the consular service of the United States," approved April 5, 1906, and has thereby made it practicable to extend to that branch of the civil service the aforesaid provisions of the Revised Statutes and the principles embodied in the Civil Service Act of January 16, 1883.

Now, therefore, in the exercise of the powers conferred upon him by the Constitution and laws of the United States, the President makes the following regulations to govern the selecion of consuls-general and consuls in the civil service of the United States, subject always to the advice and consent of the Senate:- 
1. Vacancies in the office of consul general and in the office of consul above class $\delta$ shall be filled by promotion from the lower grades of the consular service, based upon ability and effciency as shown in the service.

2. Vacancies in the office of consul of class 8 and of consul of class 9 shall be filled:

(a) By promotion on the basis of ability and efficiency as shown in the service, of consular clerks, and of vice consuls, deputy consuls, and consular agents who shall have been appointed to such offices upon examination.

(b) By new appointments of candidates who have passed a satisfactory examination for appointment as consul as hereafter provided.

3. Persons in the service of the Department of State with salaries of two thousand dollars or upwards shall be eligible for promotion, on the basis of ability and efficiency as shown in the service, to any grade of the consular service above class 8 of consuls.

4. The Secretary of State, or such officer of the Department of State as the President shall designate, the Chief of the Consular Bureau, and the Chief Examiner of the Civil Service Commission, or some person whom said Commission shall designate, shall constitute a Board of Examiners for admission to the consular service.

5. It shall be the duty of the Board of Examiners to formulate rules for and hold examinations of applicants for admission to the consular service.

6. The scope and method of the examinations shall be determined by the Board of Examiners, but among the subjects shall be included at least one modern language other than English; the natural, industrial and commercial resources and the commerce of the United States, especially with reference to the possibiities of increasing and extending the trade of the United States with foreign countries; political economy; elements of international, commercial and maritime law.

7. Examination papers shall be rated on a scale of 100 , and no person rated at less than $\delta 0$ shall be eligible for certification.

8. No one shall be examined who is under twenty-one or over fifty years of age, or who is not a citizen of the United States, or who is not of good character and habits and physically and mentally qualified for the proper performance of consular work, or who has not been specially designated by the President for appointment to the consular service subject to examination.

9. Whenever a vacancy shall occur in the eighth or ninth class of consuls which the President may deem it expedient to fill, the Secretary of State shall inform the Board of Examiners, 
who shall certify to him the list of those persons eligible for appointment, accompanying the certificate with a detailed report showing the qualifications, as revealed by examination, of the persons so certified. If it be desired to fill a vacancy in a consulate in a country in which the United States exercises extraterritorial jurisdiction, the Secretary of State shall so inform the Board of Examiners, who shall include in the list of names certified by it only such persons as have passed the examination provided for in this order, and who also have passed an examination in the fundamental principles of common law, the rules of evidence and the trial of civil and criminal cases. The list of names which the Board of Examiners shall certify shall be sent to the President for his information.

10. No promotion shall be made except for efficiency, as shown by the work that the officer has accomplished, the ability, promptness and diligence displayed by him in the performance of all his official duties, his conduct and his fitness for the consular service.

11. It shall be the duty of the Board of Examiners to formulate rules for and hold examinations of persons designated for appointment as consular clerk, and of such persons designated for appointment as vice-consul, deputy consul and consular agent, as shall desire to become eligible for promotion. The scope and method of such examination shall be determined by the Board of Examiners, but it shall include the same subjects hereinbefore prescribed for the examination of consuls. Any vice-consul, deputy consul or consular agent now in the service, upon passing such an examination shall become eligible for promotion, as if appointed upon such examination.

12. In designations for appointment subject to examination and in appointments after examination, due regard will be had to the rule, that as between candidates of equal merit, appointments should be so made as to secure proportional representation of all the States and Territories in the consular service; and neither in the designation for examination or certification or appointment will the political affiliations of the candidate be considered.

\section{THEODORE ROOSEVELT}

The White House, June 27th, 1906 


\section{IV-1-CONSULAR COURT REGULATIONS FOR CHINA, GENERAL, 1864}

\section{I - ORDINARY CIVIL PROCEEDINGS}

How

com-

menced

Three classes of action

Demand necessary in contract and replevin

Petitioner must deposit money Notice to defendant

Service

Default

Damages

Answer.

Amend. ments

Answer
1 - Civil proceedings between American citizens must commence by written petition verified by oath before the consul.

2 - Ordinary personal civil actions are of three classes, viz.: Contract, comprising all cases of contract or debt; wrong, when damages are claimed for a wrong; replevin, when possession of a specific article is claimed.

3 - In contract, the petition must aver that payment, or a performance of the conditions of contract, has been demanded and withheld; and, in replevin, that the articles to be replevied have been demanded.

4 - The petitioner shall be required to deposit a reasonable sum to defray the probable expenses of court and defendant's costs; subsequent deposits may be required if found necessary.

5 - Upon deposit of the money, the consul shall order notice on the petition, in writing, directing defendant to appear before the court at a given day and hour, to file his written answer on oath.

6 - Notice must be served on each defendant at least five days before return day, by delivery of an attested copy of the petition and order, and of any accompanying account or paper. ticable.

7 - Personal service should always be required when prac-

8 - On proof of due notice, judgment by default shall be procured against any defendant failing to appear and file his answer as required; but the default may be taken off for good cause within one day after, exclusive of Sunday.

9 - But in actions of wrong, and all others where the damages are in their nature unliquidated and indefinite, so that they cannot be calculated with precision from the statement of the petition, the amount of the judgment shall be ascertained by evidence, nothwithstanding the default.

10 - If defendant appears and answers, the consul, having both parties before him, shall, before proceeding further, encourage a settlement by mutual agreement, or by submission of the case to referees agreed on by the parties, a majority of whom shall decide it.

11 - Parties should, at the trial, be confined as closely as may be to the averments and denials of the statement and 
answer, which shall not be altered after filing, except by leave granted in open court.

12 - On application of either party and advance of the fees, the consul shall compel the attendance of any witness within his jurisdiction before himself, referees, or commissioners.

13 - Each party is entitled and may be required to testify.

14 - Judgment may be given summarily against either party failing to obey any order or decree of the consul.

15 - For sufficient cause and on sufficient security the consul, on filing a petition, may grant a process of attachment of any defendant's property to a sufficient amount, or of arrest of any defendant not a married woman, nor in the service of the United States under commission from the President.

16 - Defendant may at any time have the attachment dissolved by depositing such sums, or given such security as the consul may require.

17 - Perishable property, or such as is liable to serious depreciation under attachment, may, on petition of either party, be sold by the consul's order, and its proceeds deposited in the consulate.

18 - Any defendant arrested or imprisoned on civil petition shall be released on tender of a sufficient bond, deposit of a sufficient sum, or assignment of sufficient property.

19 - Any person under civil arrest or imprisonment may have his creditor cited before the consul to hear a disclosure of the prisoner's affairs under oath, and to question thereon; and if the consul shall be satisfied of its truth and thoroughness, and of the honesty of the debtor's conduct towards the creditor, he shall forever discharge him from arrest upon that debt; provided that the prisoner shall offer to transfer and secure to his creditor the property disclosed, or sufficient to pay the debt at the consul's valuation.

20 - The creditor must advance to the jailer his fees and payment for his prisoner's board until the ensuing Monday, and afterwards weekly, or the debtor will be discharged from imprisonment and future arrest.

21 - On the second day after judgment (exclusive of Sunday), execution may issue, enforcing the same, with interest at 12 per cent. a year against the property and person of the debtor, returnable in thirty days, and renewable.

22 - Sufficient property to satisfy the execution and all expenses, may be seized and sold at public auction by the officer, after due notice.

23 - Property attached on petition, and not advertised for sale within ten days after final judgment, shall be returned to the defendant.

American witnesses compelled to attend

Parties are witnesses Decrees to be obeyed Attachment or arrest

Dissolution of attachment

Sale of perishable

property

Release of debtor

Debtor's disclosure

Debtor's board

Execution

Seizure and sale of property 
Final judgment for defendant

Offset

Costs

Trustee process

Trustee's costs

Demand on trustee upon execution

Debt must be at least ten dollars

Replevin
24 - When final judgment is given in favor of defendant, his person and property are at once freed from imprisonment or attachment, and all security given by him discharged. And the consul may, at his discretion, award him compensation for any damage necessarily and directly sustained by reason of such attachment, arrest or imprisonment.

$25-\ln$ actions of contract, defendant may offset petitioner's claim by a counter claim, filing his own claim, under oath, with his answer. Petitioner shall be notified to file his answer seasonably, on oath, and the two claims shall then be tried together, and but one judgnient given for the difference, if any be proved in favor of either party, otherwise for defendant's costs.

26 - Except as hereinafter provided, the party finally prevailing recovers costs, to be taxed by him and revised by the consul.

27 - In contract, the consul may order defendant's property or credits in a third party's hands, to be attached on the peti. tion by serving him with due notice as trustee, provided pet1tioner secures trustee his costs by adequate special deposit.

28 - If adjudged trustee, the third party may retain hls costs from the amount for which he is adjudged trustee, if sufficient; otherwise the balance of trustee's costs must be paid out of petitioner's special deposit, as must the whole of his costs if not adjudged trustee.

29 - The amount for which a trustee is charged must be inserted in the execution, and demauded of him by the officer within ten days after judgment, or all claim on him ceases. Process against property or person of the trustee may issue ten days after demand.

30 - If petitioner recovers judgment for less than ten dollars, or if less than ten dollars of defendant's property or credits is proved in the third party's hands, in either case the third party must be discharged with costs against petitioner.

31 - Before granting a writ of replevin, the consul shall require petitioner to file a sufficient bond, with two responsible sureties, for double the value of the property to be replevied, one an American citizen; or petitioner may deposit the required amount.

$$
\text { II - TENDER, ETC. }
$$

32 - Before a creditor files his petition in contract, his debtor may make an absolute and unconditional offer of the amount he considers due, by tendering the money in the sight of the creditor or his legal representative.

33 - If not accepted, the debtor shall, at his own risk and 
paying the charges, deposit the money with the consul, who shall receipt to him and notify the creditor.

34 - It shall be paid to the creditor at any time, if demanded, unless previously withdrawn by the depositor.

35 - If the depositor does not withdraw his deposit, and, upon trial, is not adjudged to have owed the petitioner at the time of the tender more than its amount, he shall recover all his costs.

36 - At any stage of a suit in contract or wrong, defendant may file an offer to be defaulted for a specific sum and the costs up to that time; and if petitioner chooses to proceed to trial, and does not recover more than the sum offered, and interest, he shall pay all defendant's costs arising after the offer, execution issuing for the balance only.

\section{III - REFERENCE}

37 - When parties agree to a reference they shall im. mediately file a rule, and the case be marked "Referred"; a commission shall then issue to the referees, with a copy of all papers filed in the case.

38 - The referees shall report their award to the consul, who shall accept the same, and give judgment and issue execu. tion thereon, unless satisfied of fraud, perjury, corruption, or gross error in the proceedings.

39 - In cases involving more that five hundred dollars, if his acceptance is withheld, the consul shall at once transmit the whole case, with a brief statement of his reasons, and the evidence thereon, to the minister, who shall give judgment on the award, or grant a new trial before the consul.

\section{IV - APPEAL}

40 - Appeals must be claimed before three o'clock in the afternoon of the day after judgment (excluding Sunday); but in civil cases, only upon sufficient security.

41 - Within five days after judgment, the appellant must set forth his reasons by petition filed with the consul, which shall be transmitted as soon as may be to the minister, with a copy of docket entries and of all papers in the case.

\section{V-NEW TRIAL}

42 - On proof of the perjury of any important witness of the prevailing party upon a material point, affecting the decision of a suit, the consul who tried it may, within a year after final Because of perjury judgment, grant a new trial on such terms as he may deem just. 
Generally

Slaves not to be held.

Habeas corpus

Attachment.

Husband to advance money

Alimony

Minor children

Release of both

Costs. return
43 - Within one year after final judgment in any suit not involving more than five hundred dollars, the consul who tried it, or his successor, may, upon sufficient security, grant a new trial where justice manifestly requires it; if exceeding $\$ 500$, with concurrence of the minister.

\section{VI - HABEAS CORPUS}

44 - No consul shall recognize the claim of any American citizen arising out of a violation of the provisions of the act of Congress approved February 19, 1862, relating to the "coolie trade" so called, nor any claim which involves the holding any person in slavery.

45 - Upon application of any person in writing and under oath, representing that he or any other person is enslaved, unlawfully imprisoned, or deprived of his liberty by any American citizen within the jurisdiction of a consul, such consul may issue his writ of habcas corpus, directing such citizen to bring the said person, if in his custody or under his control, before him; and the question shall be determined summarily, subject to appeal.

\section{VII - DIVORCE}

46 - Libels for divorce must be signed and sworn to before the consul, and on the trial each party may testify.

47 - The consul, for good cause, may order the attachment of libeller's property to such an amount and on such terms as he may think proper.

$48-\mathrm{He}$ may also, at his discretion, order the husband to advance to his wife, or pay into court, a reasonable sum to enable her to prosecute or defend the libel, with a reasonable monthly allowance for her support, pending the proceedings.

49 - Alimony may be awarded or denied the wife on her divorce at his discretion.

50 - Custody of the minor children may be decreed to such party as justice and the children's good may require.

51 -Divorce releases both parties, and they shall not be remarried to each other.

52 - Costs are at the discretion of the consul.

$$
\text { VIII - MARRIAGE }
$$

53 - Each consul shall record all marriages solemnized by him or in his official presence.

\section{IX - BIRTHS AND DEATHS}

54 - The birth and death of every American citizen within the limits of his jurisdiction shall likewise be recorded. 


\section{X - BANKRUPTCY, PARTNERSHIP, PROBATE, ETC.}

55 - Until promulgation of further regulations, consuls will continue to exercise their former lawful jurisdiction and authority in bankruptcy, partnerships, probate of wills, administration of estates, and other matters of equity, admiralty, ecclesi. astical and common law, not specially provided for in previous decrees, according to such reasonable rules, not repugnant to the Constitution, treaties, and laws of the United States, as they may find necessary or convenient to adopt.

\section{$\mathrm{XI}$ - SEAMEN}

56 - In proceedings or prosecutions instituted by or against American seamen, the consul may, at his discretion, suspend any of these rules in favor of the seamen when, in his opinion, justice, humanity, and public policy require it.

\section{XII - CRIMINAL PROCEEDINGS}

57 - Complaints and informations against American citizens should always be signed and sworn to before the consul when the complainant or informant is at or near the consul's port.

58 - All complaints and informations not so signed and sworn to by a citizen of the United States, and all complaints and informations in capital cases, must be authenticated by the consul's certificate of his knowledge or belief of the substantial truth of enough of the complaint or information to justify the arrest of the party charged.

59 - No citizen shall be arraigned for trial until the offense charged is distinctly made known to him by the consul in re. spondent's own language. In cases of magnitude, and in all cases when demanded, an attested copy (or translation) of the complaint, information, or statement, auchenticated by the consul, shall be furnished him in his own language, as soon as may be, after his arrest.

60 - The personal presence of the accused is indispensable throughout the trial.

61 - He shall be informed of his right to testify, and cautioned that if he chooses of offer himself as a witness, he must answer all questions that may be propounded by the consul or his order, like any other witness.

62 - The government and the accused are equally entitled to compulsory process for witnesses within their jurisdiction; and if the consul believes the accused to be unable to advance the fees, his necessary witnesses shall be summoned at the ex- 
Fines and costs

Capltal cases

After conviction

American ball

Foreign bail

$\mathrm{TwO}$ sureties Surrender

Prosecutor may" be required to give security

Honorable acquittal

Costs

Minor offenses
63 - When punishment is by fine, costs may be included or remitted at the consul's discretion. An alternative sentence of thirty days' imprisonment shall take effect on non-payment of any part of the fine or costs adjudged in any criminal proceedings.

61 - Any prisoner, before conviction, may be admitted to bail by the consul who tries him, except in capital cases.

65 - No prisoner, charged with a capital offense, shall be admitted to bail where the proof is evident, or the presumption of his guilt great.

66 - After conviction and appeal, the prisoner may be admitted to bail only by the minister.

67 - Any citizen of the United States offering himself as bail shall sign and swear, before the consul, to a schedule of unencumbered personal property of a value of at least double the amount of the required bail.

68 - Any other proposed bail or security shall sign and swear before the consul to a similar schedule of unencumbered personal property within the local jurisdiction of the consulate, or he may be required to deposit the amount in money or valuables with the consul.

69 - Unless such sufficient citizen becomes bail, or such deposit is made, at least two sureties shall be required.

70 - Any American bail may have leave of the consul to surrender his principal on payment of all costs and expenses.

71 - Any complainant, informant, or prosecutor, may be re. quired to give security for all costs of the prosecution, including those of the accused; and every complainant, \&c., not a citizen of the United States, shall be so required, unless in the consul's opinion justice will be better promoted otherwise; and when such security is refused the prosecution shall abate.

72 - When the innocence of the accused, both in law and in intention, is manifest, the consul shall add to the usual judg. ment of acquittal the word "honorably".

73 - In such case judgment may be given and execution issued summarily against any informer, complainant, or prosecutor, for the whole costs of the trial, including those of the accused, or for any part of either or both, if the proceeding appears to have been groundless and vexatious, originating in corrupt, malicious, or vindictive motives.

74 -Consuls will ordinarily encourage the settlement of all prosecutions, not of a heinous character, by the parties aggrieved or concerned.

\section{XIII - OATHS}

75 - Oaths shall be administered in some language that the witness understands. 
76 - A witness not a Christian shall be sworn according to his religious belief.

77 - An avowed atheist shall not be sworn, but may affirm, under the pains and penalties of perjury; the credibility of his evidence being for the consideration of the consul.

78 - A Christian, conscientiously scrupulous of an oath, may affirm under the pains and penalties of perjury.

Not

Cliristians

Athelst

Affirmation

Civil docket

all civil actions and proceedings, entering each case separately, numbering consecutively to the end of his term of office, with the date of filing, the names of the parties in full, their nationality, the nature of the proceeding, the sum or thing claimed, with minutes and dates of all orders, decrees, continuances, appeals, and proceedings, until final judgment.

80 - He shall keep another regular docket for all criminal cases, with sufficient similar memoranda.

81 - All original papers shall be filed at once and never removed; no person but an officer of the consulate or the minister should be allowed access to them. All papers in a case must be kept together in one inclosure, and numbered as in the docket with the parties' names, the nature of the proceedings, the year of filing the petition and of final judgment conspicuously marked on the inclosure, and each year's cases kept by themselves in their order.

\section{XV - LIMITATION OF ACTIONS AND PROSECUTIONS}

$\$ 2$ - Heinous offenses, not capital, must be prosecuted with- Crimin six years; minor offenses within one.

\$3 - Civil actions based on written promise, contract, or Civil instrument must be commenced within six years after the cause of action accrues; others within two.

84 - In prosecutions for heinous offenses, not capital, and in civil cases involving more than $\$ 500$, any absence of respondent or defendant for more than three months at a time from China shall be added to the limitation; and in civil cases involving more than $\$ 100$, the period during which the cause of action may be fraudulently concealed by defendant shall likewise be added.

\section{XVI - GENERAL PROVISTONS}

85 - All trials and proceedings in the United States con- Triais, sular courts in China shall be open and public.

Absence; frauducealment 
Inter-

preting and trans-

lating

Testimony

Adjournment

Officer

Copies on appeal

Copies

Definition of consul

Associates

Contempt

Attorney

Accounts
86 - Papers and testimony in a foreign language shall be translated into English by a sworn interpreter appointed by the consul; in civil cases to be paid by petitioner. Oaths and questions shall be translated by the interpreter from the English for any witness who does not understand English.

87 - Parties may be required to file their petitions, answers, complaints, informations, and all other papers addressed to the court, in English; or they may be translated by the interpreter at the consul's discretion. All testimony must be taken in writing in open court, by the consul or his order, and signed by the witness, after being read over to him for his approval and correction, and it shall form part of the papers in the case.

88 - The consul may adjourn his court from time to time and place to place within his jurisdiction, always commencing proceedings and giving judgment at the consulate.

89 - All processes not served by the consul personally must be executed by an officer of the consulate, who shall sign his return, specifying the time and mode of service, and annexing an account of his fees.

90 - On appeal, copies of all the papers must be paid for in advance by the appellant, except in criminal cases where respondent is unable to pay.

91. - Any person interested is entitled to a copy of any paper on file, on prepayment of the fee.

92 - Reasonabie clearness, precision, and certainty should be required in the papers; and substantial justice and all practicable dispatch is expected in the decisions.

93 - The word "consul" is intended to include the consulgeneral, and any vice-consul or deputy-consul actually exercising the consular power at any consulate, unless the sense requires a more limited construction.

94 - Each associate in a consular trial shall, before entering on his duties, be sworn by the consul. Before taking the oath, he may be challenged by either party, and for sufficient cause excused and another drawn.

95 - Consuls will always preserve order in court, punishing summarily any contempt committed in their presence or any refusal to obey their lawful summons or order, by imprisonment not exceeding twenty-four hours, or by fine not exceeding $\$ 50$ and costs.

96 - Every party to a civil or criminal proceeding may be heard in person, or by attorney of his choice, or by both; but the presence of counsel shall be under the exclusive control and discretion of the consul.

97 - The accounts of the consular courts shall be kept in United States currency; and every order of deposit, decree of 
costs, taxation of fees, and, generally, every paper issuing orig. inally from the court, shall be expressed in dollars and cents, and satisfied in United States metallic currency, or its equivalent.

$$
\text { XVII - FEES }
$$

[98-105, Table of fees, omitted]

\section{XVIII - PROVISO}

106 - All decrees heretofore issued by authority of the commissioners and ministers of the United States to China, which are inconsistent in whole or in part with the provisions of this decree, are hereby annulled, and those portions are henceforth void and of no effect; and the promulgation of these rules abrogates no authority hitherto lawfully exercised by consuls in China not inconsistent herewith.

[Forms omitted]

Peking, April 23, 1864

[Signed] ANSON BURLINGAME

\section{IV-2-SAME, SUMMONS TO ABSENTEES, 1881}

I - In civil proceedings between American citizens in the consular courts in China, the service of summons upon the defendant, if he is found within the Empire of China, shall be personal; that is, the copy of the complaint and summons duly certified by a marshal of any consular court in China shall be delivered into the hands of the person to be served. The offcer so serving the summons shall certify the same to the consul, before whom the suit is brought.

II - When the defendant has removed from or is absent from the empire, or conceals himself therein to avoid the service of summons and the fact appears by affidavit to the satisfaction of the consul, and it also appears by such affidavit or by the verified complaint on file that a good cause of action exists against the defendant or that he is a necessary party to the action, such consul may make an order that the service be made by publication of the summons. Such order shall direct the publication to be made in a newspaper of general circulation (to be named) for such length of time as may be reasonable in not less than six issues of such paper, if a daily, and in not less than four issues, if a weekly. Such publication shall be made in a newspaper published nearest to the consulate, where the suit or proceeding is pending, at least five months before 
the time fixed for the trial by the consul. In case of publication, when the residence of a non-resident or absent defendant is unknown, the consul shall direct a copy of the complaint and summons, duly certified, and addressed to the person to be served at his supposed place of residence, to be deposited in the post-office by the marshal of said court.

[Signed] JAMES B. ANGELL

Peking, May 26, 1881

\section{IV-3-SAME, ARRESTS AND RENDITIONS, 1897}

Whenever a criminal action is pending in any consular district in China against a citizen of the United States of America who may be found in any other consular district in China, it shall be lawful for the consul before whom the action is pending to issue his warrant for the arrest of such citizen wherever he may be found in China.

Such warrant shall be visaed by the consul in whose district the accused may be found, and thereupon the accused shall be arrested by the United States marshal of the district in which he may be found and shall be transported to the consular district in which the case against him is pending, for trial before the consular court thereof.

Peking, September 15, 1897

[Signed] CHARLES DENBY 


\section{V-1-CUSTOMS RULES OF 1868, CHINA}

\section{RULES FOR JOINT INVESTIGATION IN CASES OF CONFIS. CATION AND FINE BY THE CUSTOM HOUSE AUTHORITIES}

Rule I - It shall be the Rule for all business connected with the Custom House Department to be in the first instance transacted between the Commissioner of Customs and the Consul, personally or by letter; and procedure in deciding cases shall be taken in accordance with the following Regulations.

Rule II - Whenever a ship or goods belonging to a foreign merchant is seized in a port in China by the Custom House officers, the seizure shall be reported without delay to the Kien-tuh, or Chinese Superintendent of Customs. If he considers the seizure justifiable, he will depute the Swui-wu-sze, or foreign Commissioner of Customs, to give notice to the parties to whom the ship or goods are declared to belong, that they have been seized because such or such an irregularity has been committed, and that they will be confiscated, unless, before noon on a certain day, being the sixth day from the delivery of the notice, the Custom House authorities receive from the Consul an official application to have the case fully investigated. The merchant to whom the ship or goods belong, if prepared to maintain that the alleged irregularity has not been committed, is free to appeal, within the limited time, directly to the Commissioner, who is to inform the Superintendent. If satisfied with his explanations, the Superintendent will direct the release of the ship or goods; otherwise, if the merchant elect not to appeal to the Customs, or if, after receiving his ex. planations, the Superintendent still declines to release the ship or goods, he may appeal to his Consul, who will inform the Superintendent of the particulars of this appeal, and request him to name a day for them both to investigate and try the case publicly.

Rule III - The Superintendent, on receipt of the Consul's communication, will name a day for meeting at the Custom House; and the Consul will direct the merchant to appear with his witnesses there on the day named, and will himself on that day proceed to the Custom House. The Superintendent will invite the Consul to take his seat with him on the bench; the Commissioner of Customs will also be seated to assist the Superintendent. 
Proceedings will be opened by the Superintendent, who will call on the Customs' employés who seized the ship or goods to state the circumstances which occasioned the seizure, and will question them as to their evidence. Whatever the merchant may have to advance in contradiction of their evidence he will state to the Consul, who will cross-examine them for him. Such will be the proceedings in the interest of truth and equity. The Consul and Superintendent may, if they see fit, appoint deputies to meet at the Custom House in their stead, in which case the order of proceedings will be the same as if they were present in person.

Rule IV - Notes will be taken of the statements of all parties examined, a copy of which will be signed and sealed by the Consul and Superintendent. The room will then be cleared, and the Superintendent will inform the Consul of the course he proposes to pursue. If he proposes to confiscate the vessel or goods, and the Consul dissents, the merchant may appeal; and the Consul, having given notice of the appeal to the Superintendent, they will forward certified copies of the above notes to Peking,- - the former to his Minister, and the latter to the Foreign Office for the decision.

If the Consul agrees with the Superintendent that the ship or goods ought to be confiscated, the merchant will not have the right of appeal; and in no case will the release of ship or goods entitle him to claim indemnity for their seizure, whether they be released after the investigation at the Custom House, or after the appeal to the high authorities of both nations at Peking.

Rule $\mathrm{V}$ - The case having been referred to superior authority, the merchant interested shall be at liberty to give a bond, binding himself to pay the full value of the ship or goods, attached, should the ultimate decision be against him; which bond, being sealed with the Consular seal, and deposited at the Custom House, the Superintendent will restore to the merchant the ship or goods attached; and when the superior authorities shall have decided whether so much money is to be paid, or the whole of the property seized be confiscated, the merchant will be called on to pay accordingly. If he decline to give the necessary security, the ship or merchandise attached will be detained. But whether the decision of the superior authorities be favorable or not, the appellant will not be allowed to claim indemnity.

Rule VI - When the act of which a merchant at any port is accused is not one involving the confiscation of ship or cargo, but is one which, by Treaty or Regulation, is punishable by fine, the Commissioner will report the case to the Superintendent, and at the same time cause a plaint to be entered in the 
Consular Court. The Consul will fix the day of the trial, and inform the Commissioner that he may then appear with the evidence and the witnesses in the case. And the Commissioner, either personally or by deputy, shall take his seat on the bench, and conduct the case on behalf of the prosecution. When the Treaty or Regulations affix a specific fine for the offence, the Consul shall on conviction give judgment for that amount, the power of mitigating the sentence resting with the Superintendent and Commissioner. If the defendant is acquitted, and the Commissioner does not demur to the decision, the ship or goods, if any be under seizure, shall at once be released, and the circumstances of the case be communicated to the Superintendent. The merchant shall not be put to an expense by delay, but he shall have no claim for compensation on account of hindrance in his business, for loss of interest, or for demurrage. If a difference of opinion exists between the Commissioner and Consul, notice to that effect shall be given to the Superintendent, and copies of the whole proceedings forwarded to Peking for the consideration of their respective high authorities. Pending their decision, the owner of the property must file a bond in the Consular Court to the full value of the proposed fine, which will be sent to the Custom House authorities by the Consul, and the goods or ship will be released.

Rule VII - If the Custom House authorities and Consul cannot agree as to whether certain duties are leviable or not, action must be taken as Rule $V$ directs, and the merchant must sign a bond for the value of the duties in question. The Consul will affix his seal to this document, and send it to the Custom House authorities, when the Superintendent will release the goods without receiving the duty; and these two functionaries will respectively send statements of the case to Peking,- one to his Minister, the other to the Foreign Office.

If it shall be decided there that no duty shall be levied, the Custom House authorities will return the merchant's bond to the Consul to be cancelled; but if it be decided that a certain amount of duty is leviable, the Consul shall require the merchant to pay it in at the Custom House.

Rule VIII - If the Consul and the Custom House authorities cannot agree as to whether confiscation of a ship, or a cargo, or both of them together, being the property of a foreign merchant, shall take place, the case must be referred to Peking for the decision of the Foreign Office, and the Minister of his nation. Pending their decision, the merchant must, in accordance with Rule V, sign a bond for the amount, to which the Consul will affix his seal, and send it for deposit at the Custom House.

As difference of opinion as to the value (of ship or goods) 
may arise, the valuation of the merchant will be decisive: and the Custom House authorities may, if they see fit, take over either at the price aforesaid.

If after such purchase it be decided that the property saized ought to be confiscated, the merchant must redeem his bond by paying in at the Custom House the original amount of the purchase-money. If the decision be against confiscation, the bond will be returned to the Consul for transmission to the merchant, and the case then be closed. The sum paid to the Custom House authorities for ship or goods being regarded as their proper price, it will not be in the merchant's power by a tender of the purchase money, to recover them.

\section{V-2-CUSTOMS RULE I, AMERICAN-CHINESE TREATY, 1903}

\section{TREATY OF OCTOBER 8, 1903, ANNEX III, PORTION OF RULE I}

. . If the goods have not been sold before presentation to the Customs of the Application to pay Duty, and should a dispute arise between Customs and importer regarding the value or classification of goods, the case will be referred to a Board of Arbitration composed as follows:

An official of the Customs; a merchant selected by the Consul of the importer; and a merchant differing in nationality from the importer, selected by the Senior Consul.

Questions regarding procedure, etc., which may arise during the sittings of the Board shall be decided by the majority. The final finding of the majority of the Board, which must be announced within fifteen days of the reference (not including holidays), will be binding upon both parties. Each of the two merchants on the Board will be entitled to a fee of Ten Haikwan Taels. Should the Board sustain the Customs valuation, or, in the event of not sustaining that valuation, should it decide that the goods have been undervalued by the importer to the extent of not less than $7 \mathrm{t} / 2$ per cent., the importer will pay the fees; if otherwise, the fees will be paid by the Customs. Should the Board decide that the correct value of the goods is 20 per cent. (or more) higher than that upon which the importer originally claimed to pay Duty, the Customs authorities may retain possession of the goods until full Duty has been paid and may lery an additional Duty equal to four times the Duty sought to be evaded.

In all cases invoices, when available, must be produced if required by the Customs. 


\section{VI-THE MUNICIPAL GOVERNMENT OF SHANGHAI ${ }^{1}$}

Chinese residents in the Foreign Settlements are amenable to their own laws, administered by a so-called Mixed Court, which was established at the instigation of Sir Harry Parkes in 1864, and originally sat at the British Consulate. It is presided over by an official of the rank of Tung-chi, or sub-prefect. The cases are watched by foreign assessors from the principal Consulates. The working of the Court, especially in regard to civil suits, is far from satisfactory, as the judge has not sufficient power to enforce his decisions. The matter has for some years been supposed to be engaging the attention of the authorities at Peking. For the French Concession there is a separate Mixed Court, which sits at the French Consulate. There is a Court of Consuls which was established in 1870, the judges of which are elected by the Consuls annually, its purpose being to enable the Municipal Council to be sued.

In local affairs the residents govern themselves by means of the Municipal Council, under the authority of the "Land Regulations." These were originally drawn up by H. B. M. Consul in 1845, but have since undergone various amendments. In 1854 the first general Land Regulations-the city charter, as they may be called-were arranged between the British Consul, Captain Balfour, and the local authorities, by which persons of all nationalities were allowed to rent land within the defined limits, and in 1863 the so-called "American Settlement" was amalgamated with the British into one Municipality. The "Committee of Roads and Jetties," originally consisting of "three upright British Merchants," appointed by the British Consul, became in 1855 the "Municipal Council," elected by the renters of land, and when the revised Land Regulations came into force in 1870 , the "Council for the Foreign Community of Shanghai North of the Yang-king-pang," elected in January of each year by all householders who pay rates on an assessed rental of five hundred taels and over. The Council now consists of nine members of various nationalities, who elect their own chairman and vice-

${ }_{1}$ Extract from European Settlements in the Far East, by D. W. Smith, London, 1900 , p. 99-102. This excellent brief description by $\mathrm{Mr}$. Smith is printed in place of extracts from the "Land Regulations," which, in their revised form, are said to be now available in this country only in the Chinese language in the archives of the Imperial Chinese Legation at Washington. 
chairman, and who give their services free. The great increase of municipal business, however, is proving so much of a tax on the time of the councillors, the chairman especially, that some new arrangement is necessary. The secretariat was in 1897 strengthened, and its efficiency increased, but no move in the direction of a change in the Council's constitution has yet been made. A committee of residents was appointed in November, 1879 , to revise the Land Regulations, and the work was considered and passed by the ratepayers in May, 1881, but the "cooperative policy," under which a voice is given to small Powers having practically no interests in China, equal to that given to Great Britain, caused a delay of seventeen years. The Regulations were again revised and passed by the ratepayers in March, 1898 , and in November the Council received a formal notification that the additions and alterations and by-laws had received the approval of the Diplomatic Body of Peking, and they have the force of law in the Anglo-American Settlement. They give the Council the power which it had for nearly twenty years been trying to get to compulsorily acquire land for new roads, the extension and widening of existing roads, the extension of lands already occupied by public works and for purposes of sanitation, and to introduce building by-laws. The rights of the foreign renters and native owners concerned are most carefully guarded, for which purpose a board of three Land Commissioners is to be constituted, one to be appointed by the Council, one by the registered owners of land in the Settlement, and one by resolution of a meeting of ratepayers. At the time of the Taiping rebellion it was proposed by the Defence Committee, with the almost unanimous consent of the landrenters and residents, to make the Settlements and City with the district around a free city, under the protection of the Treaty Powers. Had this proposal, which was thoroughly justifiable owing to the Imperial Government having lost all power in the provinces, been carried out, Shanghai would have become the chief city in China, and it is safe to say would have acted as a leaven, to the ultimate immense benefit of the whole Empire. A separate Council for the French Concession was appointed in 1862 and now works under the "Règlement d' Organisation Municipale de la Concession Française," passed in 1868. It consists of four French and four foreign members, elected for two years, half of whom retire annually. Their resolutions are inoperative until sanctioned by the Consul-General. The members are elected by all owners of land on the Concession, or occupants paying a rental of a thousand francs per annum, or residents with an annulal income of four thousand francs. This, it will be noticed, approaches much more nearly to "universal suffrage" than the 
franchise of the other Settlements, which, however, it is the intention to considerably reduce under the new Regulations. The qualification for councillors north of the Yang-king-pang is the payment of rates to the amount of fifty taels annually, or being a householder paying rates on an assessed rental of twelve hundred taels. For the French Concession the requirement is a monetary one of about the same amount. Several efforts have been made to amalgamate the French with the other Settlement;, but hitherto without success. A revision of the Règlements for the French Concession has for some time been under consideration Meetings of ratepayers are held in February or March of each year, at which the budgets are voted and the new Councils instructed as to the policy they are to pursue. No important measure is undertaken without being referred to a special meeting of ratepayers. The Council divides itself into Defence, Finance, Watch, and Works Committee. This cosmopolitan system of government has for many years worked so well and so cheaply that Shanghai has fairly earned for itself the name of "The Model Settlement." 


\title{
VII-1-RULES OF PROCEDURE FOR THE COURT OF CONSULS, SHANGHAI
}

\author{
Approved by the Consular Body, July 10, 1882
}

Rule 1 - Every petition and other pleading filed in the Court and all notices and other documents issuing from the Court shall be entitled "In the Court of Consuls."

Rule 2-The Court will appoint a Secretary whose name and address will be made public and who shall hold the olfice until the Court otherwise directs. The Secretary shall have charge of all records and, under the direction of the Court, issue and serve or cause to be served all notices and other documents. He shall also be the medium of all correspondence.

Rule 3 - Suits shall be commenced and proceeded with in person or by attorney, and suitors may be heard with or without counsel.

Rule 4-The language of the Court will be English.

Rule 5-All proceedings shall be commenced by a petition to the Court to be filed in quadruplicate and to state all facts material to the issue in distinct paragraphs.

Rule 6 - The petition will be served upon the defendant with notices to file an answer in quadruplicate within fourteen days from the date of service. A copy of the answer will be served on the plaintiff for his counsel under the direction of the Court.

Rule 7 - Amendments and other proper pleadings will be admitted upon such terms as the Court may impose, and such interim order may be made prior to the hearing of the cause as the Court may consider necessary.

Rule 8 - When it appears to the Court that a cause is ready to be heard such cause will be set down for hearing, and notice of the date and place of hearing will be given to the parties.

Rule 9 -Sittings of the Court will be public and its proceedings recorded by the Secretary.

Rule 10 - The onus of producing witnesses shall be with the parties, but the Court will, as far as practicable, aid in procuring the attendance of witnesses. Evidence will be taken on oath or otherwise as the witness may consider binding. The examination of witnesses will be conducted as the Court may direct.

Rule 11 - A failure to respond to any order or notice issued by the Court will entitle the adverse party to judgment by default, and the Court shall be empowered to give judgment accordingly.

Rule 12 - In any case upon application within sixty days 
after judgment the Court may order re-hearing upon such terms as seem just.

Rule 13 - Special cases where the facts are admitted may be submitted in writing to the Court for decision without appear. ance of the parties.

Rule 14-A minute of all orders shall be drawn up and shall be signed by the Consuls forming the Court, or a majority of them, and all orders shall be expressed to be made "By the Court" and shall be signed by the Secretary.

Rule 15 - Judgments will be given in writing by the Judges of the Court, and either be read in Court after notice or servert upon the parties.

Rule 16 - The fee shall be for hearing $\$ 10$-for each notice issued and served $\$ 3$-and such fees for recording the proceedings shall be allowed as the Court may direct. A deposit in such sum as the Court may think sufficient to secure payment of fees will be required of each petitioner. The costs, including those of counsel, in the discretion of the Court, shall be paid as the Court directs.

Rule 17 - All fees shall be at the disposal of the Court for the remuneration of the Secretary.

\section{VII-2-RULES OF 1869, MIXED COURT AT SHANGHAI ${ }^{1}$}

1-An Official having the rank of Sub-Prefect will be deputed to reside within the foreign settlement. He will have a jurisdiction in commercial suits and in civil and criminal cases, generally, within the foreign settlements. He will have an official residence, and will be furnished with the cangue, the bamboo, and the minor means of punishment. He will provide food and lodging [for prisoners].

He will decide all civil and commercial suits between Chinese resident within the settlements, and also between Chinese and foreign residents, in cases where Chinese are defendants, by Chinese law. He will be authorized to examine Chinese judicially, to detain them in custody, and to punish them by putting them in the cangue, by flogging and by other minor punishments.

2 - Where a Foreigner is concerned in a cause to be tried, a Consul or his Deputy shall sit with the Sub-Prefect at the trial; but where Chinese only are concerned the Sub-Prefect shall adjudicate independently-the Consuls shall not interfere.

1 These rules were published at Shanghai, April 20, 1869, by the British consul acting under instructions from the British minister at Peking. 
3 - Where a defendant is a native in foreign employ, the Sub-Prefect will first communicate particulars to the Consul [of the nationality concerned], who will be bound to place the parties before the Court without attempting to screen or conceal them. A Consul or his Deputy may attend the hearing, but he shall not interfere if no foreign interest is involved. The servants of non-trading Consuls shall not be arrested unless with the sanction of their masters.

4 - In cases where Chinese subjects are charged with grave offences punishable by death and the various degrees of banishment, where, by Chinese law, a local officer with an independent seal would send up the case for revision by the Provincial Judge, who would submit it to the high authorities to be by them referred to His Majesty or the Board of Punishment,--it will still be for the District Magistrate of Shanghai to take action.

Inquests, when needed, are to be held by the District Magistrate of Shanghai, independently of the Sub-Prefect.

5 - A Chinese criminal escaping to the foreign settlements can be summarily arrested by the Sub-Prefect without warrant from the District Magistrate or aid from the Municipal police.

6 - Suits between natives and foreigners shall be decided equitably and impartially, and in accordance with the Treaties. The Treaty provision is to be followed in cases where the foreigner has a Consul. When the foreigner has no Consul, the Sub-Prefect sitting with a foreign [Consular] Assessor shall try the case, submitting the decision for the consideration of the Taotai. Should either party to a case be dissatisfied with the Sub-Prefect's decision, application for a new trial can be made to the Taotai or to the proper Consul.

7 - Foreigners, who may be charged with any offence, if represented by Consul on the spot, shall be dealt with by them as the Treaties provide. Unrepresented foreign offenders will be tried and sentenced by the Sub-Prefect, the finding being submitted for the Taotai's approval, who will consult with some Treaty Power Consul on the subject. Where the offenders are Chinese, the Sub-Prefect will inflict the proper legal punishment.

8 - The necessary staff of translators, linguists, writers and servants, will be engaged by the Sub-Prefect, as also a foreigner or two for general purposes, by whom also, foreign offenders having no Consul will be brought to trial or kept in custody when necessary. All expenses are to be drawn from the Taotai monthly. Acts of extortion or annoyance on the part of any of the employers shall be severely punished.

9 - The Sub-Prefect shall keep a daily certified record of arrests made and cases tried, giving the names of the parties arrested and recording the grounds of decision in each case. This shall be open to the inspection of the superior authorities. 
Should the Sub-Prefect be inefficient or notorious he will be denounced and removed from office, another being apopinted in his place.

10 - When the Sub-Prefect has tried a case, should it be ascertained that plaintiff's charge was false or exaggerated, said plaintiff, whether native or foreigner, shall on conviction be mulcted by the Sub-Prefect in accordance with Rules which will be jointly drawn up by the Sub-Prefect and Consuls, and submitted for the Taotai's approval, and in the interests of justice, native and foreigner, must in this respect be treated with perfect impartiality.

\section{VII-3-SAME, AMENDMENTS PROPOSED IN $1906^{1}$}

1 - The International Mixed Court of Shanghai should always keep a charge book for entering all particulars of civil and other cases which may be brought up for hearing before foreign assessors and Chinese magistrates. Persons who are interested in cases will be permitted to inspect the book at all times.

2 - The public are allowed to hear all lawsuits which may be heard in the International Mixed Court, with the exception of those cases which have been appointed by the foreign asessors and Chinese magistrates for private hearing.

3 - The rank of the Chinese magistrate in the International Mixed Court is to be that of a substantive sub-prefect, who shall have power to hear and sentence all descriptions of Chinese offenders and others in the foreign Settlements north of the Yang-

1 "The Ministers of Great Britain, Germany, the United States, Austria-Hungary, Russia, Belgium, Italy, Spain, Portugal, and Japan in Peking have communicated with the Waiwupu with reference to the rectification of the existing regulations of the International Mixed Court north of the Yang-king-pang in Shanghai, stating that, owing to the extension of the International Settlements in 1898 , the number of persons under the jurisdiction of the Mixed Court north of the Yang-king-pang has since been greatly increased. As the existing regulations of the Mixed Court were drawn up so long ago as 1868, and on account of the growth of the Settlements, they require Immediate rectification. Accordingly the following twelve new regulations have been drafted by the Consuls-General in Shanghai for the information and sanction of the foreign Ministers and the Peking Government, and a copy has bren sent for perusal to his Highness Prince Ching. The new regulations are to be enforced as soon as they have been recognized by the Chinese Government.

The Customs Taotai and the Mixed Court magistrate in Shanghai have been urged by the Waiwupu carefully to consider the new regulations and give their respective opinions on them, so that the 
king-pang. The magistrate is to be assisted by one or two expectant sub-prefects, both of whom are to be placed under the control of the Customs Taotai of Shanghai.

4 - With the exception of purely Chinese cases, all other charges are to be heard by foreign assessors and Chinese mag. istrates. The former are to be appointed by the Consuls-General of the Powers.

5 - The Customs Taotai and the Consuls-General should be appealed to in case any difference of opinion or discord exist between the assessors and the magistrates concerning the decision of cases.

6 - The cells or gaols in the Mixed Court are to be controlled in accordance with the sanitary regulations of the International Municipal Council and to be inspected by the Health Officer of the Council from time to time for the preservation of health among prisoners.

7 - The warrants issued by the Mixed Court for the apprehension of Chinese residing in the International Settlements of Shanghai must always be signed and sealed by the senior Consul-General, and must also be properly signed and sealed by the Consul-General or Consul of the country to which the employers of the defaulting Chinese belong if they are employed by foreigners or foreign firms.

8 - Both plaintiffs and defendants are to be allowed to engage the services of foreign solicitors in cases which require the presence of foreign assessors in the Court. No foreign solicitors will be permitted to practise in the Court unless they have been registered and sanctioned at their respective consulates.

9 - The assessors and magistrates shall have power to suspend the permit of any foreign solicitors from practising in the Court, if they are found guilty of disobeying their instructions, for a period of not more than one month. The time of suspension can be extended to six months if agreed by their respective consuls in Shanghai.

10 - In hearing cases according to Chinese law the Mixed Court magistrate should give his decision fairly in accordance with the customs and manners of the Chinese merchants and people if there are no precedents for reference.

11 - All persons implicated in a case must obey the decisions of the Mixed Court magistrate, which are to be delivered with the acquiescence of the foreign assessors.

12-Existing regulations of the Mixed Court will remain in force if they do not conflict with any of the foregoing articles. 


\section{VII-4-RULES OF 1902, MIXED COURTS OF THE INTERNATIONAL AND FRENCH SETTLEMEN'TS ${ }^{1}$}

1 - In all civil cases between Chinese the plaintiff will follow the defendant, and will sue him before the Mixed Court of his (the defendant's) residence.

2 - In all criminal cases of Chinese against Chinese, where foreigners are not concerned, and in all police cases against Chinese residents in the Settlements, the Mixed Court of the Settlement in which the crime or contravention has been committed is alone competent.

3 - In mixed civil cases-

(a) If the plaintiff is a foreigner (not of French nationality) and the Chinese defendant is a resident of the International Settlement, he is to be sued before the Mixed Court of the International Settlement.

(b) If the plaintiff is French and the Chinese defendant is a resident of the French Settlement, he is to be sued before the Mixed Court of the French Settlement.

(c) If the plaintiff is a foreigner (not of French nationality) and the Chinese defendant is a resident of the French Settlement, the latter shall be sued before the Mixed Court of the International Settlement, whose warrant or summons for his appearance, after counter-signature by the French Consul-General, will be executed or served by the runners of the International Mixed Court, with the assistance of the police of the French Settlement, without previous hearing in the Mixed Court of the French Settlement.

(d) If the plaintiff is French and the Chinese defendant is a resident of the International Settlement, the latter shall be sued before the Mixed Court of the French Settlement, whose warrant or summons for his appearance, after counter-signature by the Senior Consul, will be executed or served by the runners of the French Mixed Court, with the assistance of the police of the International Settlement, without a previous hearing in the Mixed Court of the International Settlement.

4 - In criminal cases where a foreigner (not of French nationality) is complainant, the Mixed Court of the International Settlement is competent; if a Frenchman is complainant, the Mixed Court of the French Settlement is competent.

The provisions under clauses 3 (c) and 3 (d) as to executing warrants also apply under this clause.

Shanghai, June 10, 1902.

${ }^{1}$ Parliamentary Papers, 1903, vol. 1v, p. 603. 
VIII-MACDONALD $v$. ANDERSON, TIENTSIN, 1904 ${ }^{1}$

PORTION OF OPINION BY F. S. A. BOURNE, J., OF THE BRITISH SUPREME COURT FOR CHINA

Mr. Kent [for defendant] relied firstly on Hanson $v$. Watson ("North China Herald," 8th October, 1899) in which Hannen, C. J., decided that Shanghai land held under a perpetual lease was realty in English law, and secondly on the principle that limitation of action belongs to procedure which is governed by the lex fori, that is here English law. In regard to the first point I hold that the law of China ought to be applied to the facts of this case. The Court administers the law of England (1865 Order-in-Council, art. 5), but what is the law of England in regard to immovable property situated within the dominions of the Emperor of China? Undoubtedly that rights in respect of such property shall be governed by the lex situs, that is by the law of China (Story's Conflict of Law, ch. X: Heffter, $\S 42$, V; Dicey's Conflict of Laws, Rule 138: Wushishan case, "North China Herald," XXIII, p. 90).

To apply the law of English realty to land under the sovereignty of China is to disregard the distinction between the real and personal statutes-a fundamental principle of Private International Law which can be traced back through the legal history of the Western world to the time of the Roman Republic, and which is as necessary to-day as ever. It is true that our extraterritorial rights in China are not rooted in the history of Western law, as are those in the Levant, for they are the creatures of the Treaties with China, the earliest of which was ratified in 1842; but I think there is no doubt that the Orders-in-Council, from which this Court derives its jurisdiction, were framed on the long-established lines of an extraterritorial personal law. When article 5 of the Orders-in-Council of 1865 provides that His Majesty's jurisdiction shall, as far as circumstances admit, be exercised upon the principles and in conformity with the Common Law, the Rules of Equity, the Statute Law and other law for the time being in force in and for Eng. land, it could not have been intended that the Court was to apply to land in China the English law in regard to land in England (cf. Westlake, 3rd edition, p. 226). A well-known rule of

${ }^{1}$ The judgment was pronounced on January 16, 1904. The case is reported in North China Herald, February 5, 1904, vol. 1xxii, p. 247-50. 
construction requires that such an intention being to change the Common Law, should be explicitly stated (cf. Story, §463): "It is in the last degree improbable that the Legislature would overthrow fundamental principles . . . without expressing its intention with irresistible clearness." (Maxwell's Interpretation of Statutes, 3rd edition, p. 113.) The principle that land and its incidents are subject to the lox situs is not arbitrary, but founded upon cogent considerations of justice and convenience-one of the most obvious of which is that contiguous plots of land should be subject to the same law in regard to such incidents as prescription and servitudes. The land of British subjects at Tientsin is often conterminous with that owned by Frenchmen, Germans and subjects of other Treaty Powers. If the home land law of each proprietor is to apply to his land at Tientsin there will be different periods of limitation, prescription for servitudes, etc., according to the nationality of the owner for the time being. For example, the German period of limitation is 30 years with conditions, (German civil cocle \$927) and the French also 30 years (code Napoleon civil, $\$ 2262$ ), while the English is 12 years; that is, a British subject could acquire a title to a part of his German neighbor's land by 12 years possession, while the German could only get the same right by 30 years possession of the British subject's land, or the German might reduce the necessary period from 30 to 12 years by transferring the legal estate to a British subject. Such injustice and confusion must in any case throw doubt on a construction involving them; but $I$ can find no colour for such a construction either in the Foreign Jurisdiction Act or in the China Orders-inCouncil. The same reasoning excludes the law of the owner's domicile; and cf. $D o \mathcal{c} d c m$. Birtwhistle $v$. Vardell, 5 B. and C., p. 451, per Abbott, C. J. Morever, supposing that we were in a circulus inextricabilis and that while English law applies the $l_{c} x$ situs, the lex situs applies English law, that law cannot be the law of realty, and must, therefore, English law being exhypothesi to be applied, be the law of personalty. For the distinction in English law between realty and personalty is not founded on principle, but is historically derived from the old forms of actions (cf. Goodere's Real Property, 3rd ed., p. 6). Realty included only interests in land for the enforcement of which a real action was available. But a real action in England was not open to a Plaintiff in regard to any interest in land but freehold, certainly not in regard to land under sovereignty of a Foreign Prince, a result utterly repugnant to feudal theory (Digby's Law of Real Property, p. 69). Therefore, foreign land cannot be realty in English law, unless explicitly made so by legislation. Supposing then English law has to be applied, land 
in China would fall under the same law as English chattels real, and for the same reason-that there would have been no real action open to the Plaintiff (cî. Williams' Real Property, 16th ed., p. 2). When foreign lands-even foreign possessions of the Crown-were intended to be held under an English feudal tenure, this was explicitly stated, $\varepsilon$. g., when in 1669 Charles II granted Bombay to the East India Company it was "to be held of the King in common soccage as of the Manor of East Greenwich." Stress was laid at the Bar and in the judgment in Hanson $v$. Watson on the fact that the tenure of the Chinese land in question corresponded with some particular English tenure of land. But that would seem to be immaterial. Will the Courts in England apply the English law of realty to possession or ownership of land in the United States because the conditions of the tenure chance to agree with some English mode of holding land? The question is precluded by the fact that the land is foreign. But I should have been bound by the decision in Hanson $\%$. Watson if that case had not been virtually overruled, as it seems to me, by a subsequent case in the Privy Council, Secretary of State for Foreign Afiairs $i$. Charlesworth Pilling \& Co., (1901) A. C., p. 373. Their Lordships say at p. 384: "It is going a long way beyond the immunities accorded to British subjects in Zanzibar, and beyond the reason of these immunities to say that the moment a plot of land is purchased by an Englishman it is stamped with the same character and is attended by the same incidents that would belong to it if it were actually transferred to England and surrounded by other English land; and to say that his neighbors, who may or may not be British subjects, must have their rights and liabilities governed by its fictitious and not by its actual situation. Their Lordships hold that the grant of extraterritoriality does not involve any such conclusion, and that the Vice-Consul is right in holding that "in this case the local law applies." It is true that the court in Zanzibar had as its local law the Mahomedan code, a certain written law, while we in China are thrown back on a very few written rules-the Penal code-the greater part of which cannot be applied to a Christian community-upon local customs and upon the Judge's conscience. But that is not a legal reason for applying the English feudal tenures to land in China, although it may be a moral one for legislation. I am clear that I ought to apply Chinese law to the facts of this case.

In regard to Mrr. Kent's second contention that limitation of action belongs to procedure and is therefore governed by the le $x$ fori, although Professor Dicey at page 525 leans to the opinion that limitation of action in regard to immovables is governed by the $l c x$ fori, 1 think the reasoning of Mr. Foote on 
pages 142 to 145 of his Private International Jurisprudence, read in connection with the facts of this case, is conclusive that where the $l e x$ situs and $l e x$ fori are different, as they are here, limitation of action must be governed by the former. Cf. Pitt $v$. Dacre 1876, $3 \mathrm{Ch}$. D. 295; (Westlake $\$ 171$.$) I therefore hold$ that Real Property Limitation Act does not apply.

. . . The law applicable to land in China owned by His Majesty's subjects has been so long a moot point and the interests involved are so large that I think I ought, now that the question has been raised by this suit, to state my opinion of the effect of the Judgment of the Privy Council in the above case-Secretary of State $i$. Charlesworth Pilling \& Co. (1901) A. C. p. 373. That case seems by analogy to establish two propositions, that Chinese law ought to be applied by His Majesty's Courts in China to the incidents of land in China, and that His Majesty's judges in China ought to take judicial notice of Chinese law. In regard to the first, the greater part of Chinese written law would be void and inoperative in an English Court as inconsistent with the policy of English law-Dicey, pp. 29 and 32 : Fitzgerald, in re (1903) $1 \mathrm{Ch}$. 941. Further Chinese land law consists almost entirely of local custom: a great deal of Eng. lish law has been uniformly followed for half a century by His Majesty's subjects in China, and has thus acquired the force of Chinese law, $c . g$. , testamentary disposition of land in China according to the English form, and English forms of conveyancing. Where there is no custom, the duty of the Chinese judge is to decide according to good conscience. The British Court would, I conceive, in such cases draw on the civil law as developed by modern continental codes and text-writers, including our own law of personal property, which comes in some respects from the same source, cf. Maine's Ancient Law, page 283. If a land law so derived is thought too uncertain to support the large foreign commercial interests now centered in Shanghai and Tieutsin, legislation alone can supply the remedy. Rights of limitation and servitudes might be governed by Land Regulation approved by the Treaty Powers, and succession ab intestato by Order-in-Council. In regard to judicial notice, there is in fact no Chinese written civil law. Judicial notice might be taken of the Penal Code of the present dynasty, translated by Staunton, London, 1810, but custom would have to be proved by evidence. 


\section{IX-CONSULAR COURT REGULATIONS FOR TURKEY, 1862}

\section{I - ORDINARY CIVIL PROCEEDINGS}

How

commenced

Three classes of ordinary actions

Demand necessary in contract and replevin.

Petitioner to deposit money.

Notice to defendant

Service

Defauit

Damages

Answer Settlement or reference encour-

aged

Amend. ments
1 - Civil proceedings between American citizens must commence by written petition verified by oath before the consul.

2 - Ordinary personal civil actions are of three classes, viz.:

Wrong-when damages are claimed for a wrong.

Contract-comprising all cases of contract or debt.

Rcplevin-when possession of a specific article is claimed.

3 - In contract, the petition must aver that payment or a performance of the conditions of the contract has been demanded and withheld; and in replevin, that the articles to be replevied have been demanded.

4 - The petitioner shall be required to deposit a reasonable sum to defray the probable expenses of court and defendant's costs. Subsequent deposits may be required, if found necessary.

5 - Upon deposit of the money, the consul shall order notice on the petition in writing, directing defendant to appear before him at a given day and hour to file his written answer on oath.

6 - Notice must be served on each defendant at least five days before return day, by delivery of an attested copy of the petition and order and of any accompanying account or paper.

7 - Personal service should always be required when practicable.

8 - On proof of due notice, judgment by default shall be pronounced against any defendant failing to appear and file his answer as required; but the default may be taken off for good cause, within one day after (exclusive of Sunday).

9 - But in actions of wrong and all others where the damages are in their nature unliquidated and indefinite, so that they cannot be calculated with precision from the statements of the petition, the amount of the judgment shall be ascertained by evidence, notwithstanding the default.

10 - If defendant appears and answers, the consul, having both parties before him, shall, before proceeding further, encourage a settlement by mutual agreement or by submission of the case to referees agreed on by the parties, a majority of whom shall decide it.

11 - Parties should at the trial be confined as closely as may be to the averments and denials of the statement and answer, which shall not be altered after filing except by leave granted in open court. 
12 - On application of either party and advance of the fees, the consul shall compel the attendance of any witness within his jurisdiction, before himself, referees, or commissioners.

13 - Each party is entitled, and may be required, to testify.

14 - Judgment may be given summarily against either party failing to obey any order or decree of the consul.

\section{ATTACHMENT AND ARREST}

15 - For sufficient cause and on sufficient security, the consul, on filing a petition, may grant a process of attachment of any defendant's property to a sufficient amount, or of arrest of the person of any defendant not a married woman, nor in the service of the United States under commission from the President, nor otherwise exempted by law.

16 - Defendant may at any time have the attachment dissolved by depositing such sum or giving such security as the consul may require.

17 - Perishable property, or such as is liable to serious depreciation under attachment, may, on petition of either party, be sold by the consul's order and its proceeds deposited in the consulate.

18 - Any defendant arrested or imprisoned on civil petition shall be released on tender of a sufficient bond, deposit of a sufficient sum, or assignment of sufficient property.

19 - Any person under civil arrest or imprisonment may have his creditor cited before the consul to hear a disclosure of the prisoner's affairs under oath, and to question him thereon, and if the consul shall be satisfied of its truth and thoroughness, and of the honesty of the debtor's conduct toward the creditor, he shall forever discharge him from arrest upon that debt, provided the prisoner shall offer to transfer and secure to his creditor the property disclosed or sufficient to pay the debt, at the consul's valuation.

20 - The creditor must advance to the jailer his fees and payment for his prisoner's board until the ensuing Monday, and afterwards weekly, or the debtor will be discharged from imprisonment and future arrest.

\section{EXECUTION}

21 - On the second day after judgment (exclusive of Sunday) execution may issue enforcing the same, with interest at 12 per cent. a year, against the property and person of the debtor, returnable in 30 days and renewable. 
Selzure and sale of property

Effect of final judgment for defendant

22 - Sufficient property to satisfy the execution and all expenses may be seized and sold at public auction by the officer after due notice.

23 - Property attached on petition and not advertised for sale within ten days after final judgment shall be returned to the defendant.

$24-$ When final judgment is given in favor of defendant, his person and property are at once freed from imprisonment or attachment, and all security by him given discharged. And the consul may, at his discretion, award him compensation for any damage necessarily and directly sustained by reason of such attachment, arrest, or imprisonment.

\section{EXEMPTION AND DISCHARGE}

25 - The consul may exempt from attachment, seizure, or assignment any articles of personal property indispensable to the comfort of the owner or his family, and he may at any time release or bail any debtor, discharge any security or dissolve the whole, or a part, of any attachment, when justice requires.

\section{OFFSET}

26 - In actions of contract, defendant may offset petitioner's claim by any contract claim, filing his own claim under oath with his answer. Petitioner shall be notified to file his answer seasonably on oath, and the two claims shall then be tried together and but one judgment given for the difference, if any be proved, in favor of either party; otherwise for defendant's costs.

\section{$\cos T$}

27 - Except as hereinafter provided, the party finally prevailing recovers costs, to be taxed by him and revised by the consul.

\section{TRUSTEE PROCESS}

28 - In contract, the consul may order defendant's property or credits in a third party's hands within the jurisdiction of the United States to be attached on the petition, by serving him with due notice as trustee, provided petitioner secures trustee his costs by adequate special deposit.

29 - If adjudged trustee, the third party may retain his 
out of petitioner's special deposit, as must the whole of his costs if not adjudged trustee.

30 - The amount for which a trustee is charged must be inserted in the execution and demanded of him by the officer within ten days after judgment, or all claim on him ceases. Process against the property or person of trustee may issue ten days after demand.

31 - If petitioner recovers judgment for less than $\$ 10$, or if less than $\$ 10$ of defendant's property or credits is proved in the third party's hands-in either case the third party must be discharged, with costs against petitioner.

\section{REPLEVIN}

32 - Before granting a writ of replevin, the consul shall require petitioner to file a sufficient bond, with two responsible sureties, for double the value of the property to be replevied, one an American citizen, or petitioner may deposit the required amount.

\section{II - TENDER, E'TC.}

33 - Before a creditor files his petition in contract, his debtor may make an absolute and unconditional offer of the amount he considers due by tendering the money in the sight of the creditor or his legal representative.

34 - If not accepted, the debtor shall, at his own risk and paying the charges, deposit the money with the consul, who shall receipt to him and notify the creditor.

35 - It shall be paid to the creditor at any time if demanded, unless previously withdrawn by depositor.

36 - If the depositor does not withdraw his deposit, and upon trial is not adjudged to have owed petitioner at the time of the tender more than its amount, he shall recover all his costs.

\section{OFFER TO BE DEFAULTED}

37 - At any stage of a suit in contract or wrong, defendant may file an offer to be defaulted for a specific sum and the costs up to that time, and if petitioner chooses to proceed to trial, and does not recover more than the sum offered and interest, he shall pay all defendant's costs arising after the offer, execution issuing for the balance only. 


\section{III - REFERENCE}

38 - When parties agree to a reference, they shall immediately file a rule and the case be marked "Referred"; a commission shall then issue to the referees, with a copy of all papers filed in the case.

Award and acceptance

When transmitted to minister

To be claimed within one day

Must be per-

fected

within

five days

Appeal of prisoner sent to Constantinople

For perjury.

Generally

39 - The referees shall report their award to the consul, who shall accept the same and give judgment and issue exexcution thereon, unless satisfied of fraud, perjury, corruption, or gross error in the proceedings.

40 - In cases involving more than $\$ 500$, if his acceptance is withheld, the consul shall at once transmit the whole case, with a brief statement of his reasons and the evidence therefor, to the minister resident, who shall give judgment on the award or grant a new trial before the consul.

\section{IV - APPEAL}

41 - Appeals must be claimed before three o'clock in the afternoon of the day after the judgment (excluding Sunday), but in civil cases only upon sufficient security.

42 - Within five days after judgment, the appellant must set forth his reasons by petition filed with the consul, which shall be transmitted as soon as may be through the consulgeneral to the minister, with a copy of the docket entries and of all papers in the case.

43 - The consul-general may allow any prisoner (by law entitled to appeal) sent to Constantinople for imprisonment on sentence of a consul, to file his appeal within ten days after notice of his arrival, if in his judgment justice would be promoted thereby, requiring such prisoner to file with the appeal his petition, which shall be at once transmitted to the minister.

\section{$\mathrm{V}-\mathrm{NEW}$ TRIAL}

44 - On proof of the perjury of any important winess of the prevailing party upon a material point affecting the decision of a suit, the consul who tried it may within a year after final judgment grant a new trial, on such terms as he may deem just.

45 - Within one year after final judgment in any suit involving not more than $\$ 500$, the consul who tried it, or his successor, may upon sufficient security grant a new trial, when justice manifestly requires it; if exceeding $\$ 500$, with concurrence of the minister. 


\section{VI - HABEAS CORPUS}

46 - No consul shall recognize the claim of any American citizen to hold any person in slavery or bondage within the Turkish Empire.

47 - Upon application of any person in writing and under oath, representing that he or any other person is enslaved, unlawfully imprisoned, or deprived of his liberty by any American citizen within the jurisdiction of a consul, such consul or the consul-general may issue his writ of habeas corpus directing such citizen to bring said person, if in his custody or under his control, before him, and the question shall be determined summarily, subject to appeal.

\section{VII — DIVORCE}

48 - Libels for divorce must be signed and sworn to before the consul, and on the trial each party may testify.

49 - The consul, for good cause, may order the attachment of libellee's property to such an amount and on such terms as he may think proper.

$50-\mathrm{He}$ may also, at his discretion, order the husband to advance to his wife or pay into court a reasonable sum to enable her to prosecute or defend the libel, with a reasonable monthly allowance for her support pending the proceedings.

51 - Alimony may be awarded or denied the wife on her divorce at his discretion. Custody of the minor children may be decreed to such party as justice and the children's good may require.

52 - Divorce releases both parties, and they shall not be Release remarried to each other.

53 - Costs are at the discretion of the consul.

Parties are witnesses

Attachment

Husband to advance money

Alimony children of both.

Costs

Record and return him, or in his official presence, and at the end of each year transmit a copy to the Secretary of State and to the consulgeneral.

\section{IX - BIRTHS AND DEATHS}

55 - The birth and death of every American citizen or protégé within the limits of his jurisdiction shall likewise be recorded and annually transmitted. 
List of Citizens

List of protégés

Annual return

Registration

Consul's former authority continued

How

com-

menced

How authenticated

\section{$\mathrm{X}$ - LIST OF CITIZENS AND PROTEGES}

56 - Each consul shall prepare and keep a correct list of all adult male citizens of the United States living within his jurisdiction, with their age, birth place, occupation, residence, and year of arrival in Turkey, and the names, \&c., of the members of their families; adding the date and court in case of naturalized citizens.

57 - Also a similar list of a protégés of the United States, adding the year of their original protection, by whom it was granted, and where; also the date of their last permit of residence and by whom issued.

58 - A copy of said lists shall be transmitted to the Secretary of State, to the minister resident and to the consul-general, when completed, and a memorandum of the changes at the end of each year. And every citizen and protégé is required to register himself and family at the consulate each December.

\section{XI - BANKRUPTCY, PARTNERSHIP, PROBATE, \&c.}

59 - Until promulgation of further regulations, consuls will continue to exercise their former lawful jurisdiction and authority in bankruptcy, partnership, probate of wills, administration of estates, and other matters of equity, admiralty, ecclesiastical and common law not specially provided for in the foregoing orders, according to such reasonable rules, not repugnant to the Constitution, treaties, and laws of the United States, as they may find necessary or convenient to adopt.

\section{XII - SEAMEN}

60 - In proceedings or prosecutions instituted by or against American seamen, the consul may, at his discretion, suspend any of these rules in favor of the seaman, when, in his opinion, justice, humanity, and public policy require it.

\section{XIII - CRIMINAL PROCEEDINGS}

61 - Complaints and informations against American citizens should always be signed and sworn to before the consul, when the complainant or informant is at or near the consul's post.

62 - All complaints and informations not so signed and sworn to by a citizen of the United States, and all complaints and informations in capital cases, must be authenticated by the consul's certificate of his knowledge or belief of the substantial 
truth of enough of the complaint or information to justify the arrest of the party charged.

63 - No citizen shall be arraigned for trial until the offense charged is distinctly made known to him by the consul in respondent's own language; in cases of magnitude, and in all cases when demanded, an attested copy (or translation) of the complaint, information, or statement authenticated by the consul shall be furnished him in his own language as soon as may be after his arrest.

$64-$ The personal presence of the accused is indispensable throughout the trial.

65 - He shall always have and be informed of his right to testify, and cautioned that if he chooses to offer himself as a witness, he must answer all questions that may be propounded by the consul or his order, like any other witness.

66 - The government and the accused are equally entitled to compulsory process for witnesses with the jurisdiction of the United States; and if the consul believes the accused unable to advance the fees, his necessary witnesses shall be summoned at the expense of the United States.

67 - When punishment is by fine, costs may be included or remitted at the consul's discretion; an alternative sentence of not less than 30 days' imprisonment may take effect on nonpayment of any part of the fine or costs adjudged in any criminal proceeding.

68 - Any prisoner before conviction may be admitted to bail by the consul who tries him, except in capital cases.

69 - No prisoner charged with a capital offense shall be admitted to bail where the proof is evident or the presumption of his guilt great.

70 - After conviction and appeal, the prisoner may be admitted to bail only by the minister or consul-general.

71-Any citizen of the United States offering himself as bail shall sign and swear before the consul to a schedule of unencumbered property of a value at least double the amount of the required bail.

72 - Any other proposed bail or security shall sign and swear before the consul to a similar schedule of unencumbere 1 personal property within the local jurisdiction of the consulate, or he may be required to deposit the amount in money or valuables with the consul.

73 - Unless such sufficient citizen becomes bail, or such Two deposit is made, at least two sureties shall be required. sure-

74 - Any American bail may have leave of the consul to surren. surrender his principal on payment of all costs and expenses. 
Prosecutor may be required to give security

Costs

Minor offenses

Lan-

guage

Not

Chris-

tians

A theists

Affirmation.

Civil docket

Criminal docket
75 - Any complainant, imformant, or prosecutor may be required to give security for all costs of the prosecution, including those of the accused; and every complainant, \&c., not a citizen of the United States shall be so required, unless, in the consul's opinion, justice will be better promoted otherwise; and when such security is refused the prosecution shall abate.

\section{HONORABLE ACQUITTAL}

76 - When the innocence of the accused both in law and in intention is manifest, the consul shall add to the usual judgment of acquittal the word "Honorably."

77 - In such case judgment may be given and execution issued summarily against any informer, complainant, or prosecutor for the whole costs of the trial, including those of the accused, or for any part of either or both, if the proceeding appears to have been groundless and vexatious, originating in corrupt, malicious, or vindictive motives.

78 - Consuls will ordinarily encourage the settlement of all prosecutions not of a heinous character by the parties aggrieved or concerned.

\section{XIV - OATHS}

$79-$ Oaths shall be administered in some language that the witness understands.

80 - A witness not a Christian shall be sworn or examined according to his religious belief.

81 - An avowed atheist shall not be sworn, but may affirm under the pains and penalties of perjury, the credibility of his evidence being for the consideration of the consul.

82-A Christian conscientiously scrupulous of an oath may affirm under the pains and penalties of perjury.

\section{XV - DOCKETS, RECORDS, \&c.}

83 - Each consul shall keep a regular docket or calendar of all civil actions and proceedings, entering each case separately, numbering consecutively to the end of his term of office, with the date of filing, the names of the parties in full, their nationality, the nature of the proceeding, the sum or thing claimed, with minutes and dates of all orders, decrees, continuances, appeals, and proceeding until final judgment.

84 - He shall keep another regular docket for all criminal cases with sufficient similar memoranda. 
85 - Upon final judgment each case shall be recorded in a Records book of records, at sufficient length to identify it and prevent a second proceeding for the same cause.

86 - Civil proceedings are to be kept distinct from criminal Annual and recorded in separate books, and returns of each made to returns the consul-general at the end of each year.

87 - Each docket and book records shall contain an index. Index.

88 - All original papers shall be filed at once and never re- Filing moved; no person but an officer of the consulate or the minister should be allowed access to them. All papers in a case must be kept together in one inclosure and numbered as in the docket with the parties' names, the nature of the proceeding, the year of filing the petition and of final judgment conspicuously marked on the inclosure and each year's cases kept by themselves in their order.

\section{XVI - LIMITATION OF ACTIONS AND PROSECUTIONS}

89 - Heinous offenses, not capital, must be prosecuted Criminal within six years; minor offenses within one.

90 - Civil actions based on written promise, contract, or instrument must be commenced within six years after the cause of action accrues; others within two.

91 - In prosecutions for heinous offenses, not capital, and in civil cases involving more than $\$ 500$, any absence of respondent or defendant for more than three months at a time from Turkey shall be added to the limitation; and in civil cases involving more than $\$ 100$ the period during which the cause of action may be fraudulently concealed by defendant shall likewise be added.

92 - No action in contract, replevin, or wrong shall be commenced for less than $\$ 5$, no trustee process for less than $\$ 1$, no property attached for less than $\$ 25$, nor the person arrested for less than $\$ 50$; and if petitioner recovers less than the respective amount in either case, he shall pay all costs unless for special reasons to the contrary.

\section{XVII - GENERAL PROVISIONS}

93 - All trials and proceedings in the United States consular courts in Turkey shall be open and public and condicted Trials public in the English language.

94 - Papers and testimony in a foreign language shall be translated into English by a sworn interpreter appointed by the consul; in civil cases to be paid by petitioner. Oaths and ques-

Civll 
Translations

Testimony

Adjournments

First Monday

Holidays

Officer

Copies on appeal

Copies

Definition of "consul"

Associates

Contempt punIshed

Attorney tions shall be translated by the interpreter from the English for any witness who does not understand English.

95 - Parties may be required to file their petitions, answers, complaints, informations, and all other papers addressed to the court, in English, or they may be translated by the interpreter, at the consul's discretion. All testimony must be taken in writing in open court by the consul or his order and signed by the witness after being read over to him for his approval and correction, and it shall form part of the papers in the case.

96. - The consul may adjourn his court from time to time and place to place within his jurisdiction, always commencing proceedings and giving judgment at the consulate.

97 - The first Monday of each month shall be a regular court day to which civil actions will stand adjourned unless otherwise provided for.

98 - No court shall sit ou February 22, July 4, December 25, or on any Sunday.

99 - All processes not served by the consul personally must be executed by an officer of the consulate, who shall sign and swear to his return before the consul, specifying the time and mode of service and annexing an account of his fees; process from the consul-general shall be served by the marshal or his deputy.

100 - On appeal, copies of all the papers must be paid for in advance by the appellant, except in criminal cases where respondent is unable to pay.

101 - Any person interested is entitled to a copy of any paper on file on prepayment of the fee.

102 - Reasonable clearness, precision, and certainty should be required in the papers, and substantial justice and all practicable dispatch is expected in the decisions; but technical accuracy is not essential.

103 - The word "consul" is intended to include the consulgeneral, and any vice-consul or deputy consul actually exercising the consular power at any consulate, unless the sense requires a more limited construction.

104 - Each associate in a consular trial shall, before entering on his duties, be sworn by the consul. Before taking the oath, he may be challenged by either party and for sufficient cause excused and another drawn.

105 - Consuls will always preserve order in court, punishing summarily any contempt committeed in their presence or any refusal to obey their lawful summons, or order, by imprisonment not exceeding 24 hour's, or by fine not exceeding $\$ 50$, and costs.

106 - Every party to a civil or criminal proceeding may be heard in person or by attorney of his choice, or by both, but 
the presence of counsel shall be under the exclusive control and discretion of the consul.

107 - The accounts of the consular courts shall be kept in United States currency, and every order or deposit, decree of costs, taxation of fees, and generally every such paper issuing originally from the court, shall be expressed in dollars and cents, and satisfied in United States metallic money or its equivalent coin as fixed by law.

\section{XVIII - PROCEEDINGS WITH FOREIGNERS.}

105 - All petitions, informations, complaints, and other papers from subjects of the Sublime Porte, or subjects or citizens of any other friendly power, should be communicated through the Turkish authorities or the consulate of such other power.

109 - All notices, answers, \&c., should be communicated to such subject or citizen through said authorities or such consulate, respectively.

\section{XIX - MIXED COMMISSIONS}

110 - When any foreign petitioner is entitled to a mixed commission the suit shall be tried at the United States consulate or such place as the United States consul may direct, and proceedings shall be conducted as nearly as may be as in suits between citizens of the United States.

111 - Every commissioner nominated by a foreign authority must have his appointment acknowledged and approved by the United States consul before taking his seat on the commission; and all objections to the approval of the nomination or appointHow communicated. etc., in United States money ment of either commissioner shall be heard and determined by the consul summarily and without appeal.

112 - The commissioner appointed by the United States consul should be a citizen of the United States, when practicable; he will always preside, and his presence is indispensable throughout the proceedings

\section{$\mathrm{XX}$ - DESIGN OF THE RULES}

The promulgation of these ruies abrogates no authority hitherto lawfully exercised by consuls not inconsistent herewith. 


\section{$\mathrm{XXI}$ - CHANGES}

Whenever, in the opinion of the consul, a change becomes necessary in the rules, the proposed change, with the reasons, shall be communicated in writing to the minister, and, the change approved by him, be submitted to the other consuls and published over his signature before going into effect.

[Forms and Table of Costs and Fees, omitted]

\section{[Signed] E. JOY MORRIS}

Constantinople, December 18, 1862 


\section{X-PORTION OF LORD CROMER'S REPORT ON EGYPT, $1906^{1}$}

I now turn to the important questions of criminal and civil jurisdiction.

I propose that the jurisdiction at present exercised in Egypt by Consular authorities in civil and criminal affairs shall cease, pari passu with the provision by the Egyptian Government, under the powers conferred and after adopting the legislative procedure prescribed by the Treaty which will have to be signed with the Powers, of Courts having competence to deal with such matters.

I do not, however, propose that complete legislative freedom of action in criminal matters should be conferred jointly on the British and Egyptian Governments acting with the assent of the new [Legislative] Council. I suggest the following reservations:

(a) That no subject or protected subject of any of the Treaty Powers shall be proceeded against for any offence under any procedure which shall not insure to him the right of having his case submitted, before it is finally decided, to a Judge who is himself a subject of one of those Powers, or to a Tribunal in which the proportion of members who are subjects of those Powers is not less than three-fifths.

(b) That no sentence of imprisonment, or more severe sentence, passed upon a subject or protected subject of any of those Powers shall become enforceable, without the option of finding bail, until the accused person shall have had opportunity of causing his case to be submitted to such Judge or Tribunal as aforesaid.

(c) That no warrant for the arrest of any subject or protected subject of a Treaty Power shall be issued otherwise than by a Magistrate who is himself a subject of a Treaty Power, or with the authorization of such Magistrate.

(d) That any subject or protected subject of a Treaty Power who is arrested on a criminal charge shall be entitled to be liberated on bail, or be brought within twenty-four hours before a Magistrate who is the subject of a Treaty Power.

(c) That no search warrants or similar process, the execution of which involves the entry upon premises for access to which Consular intervention is necessary under the Capitulations, shall be issued otherwise than by a Magistrate who is the sub-

1 Reports, Egypt No. 1, 1906 (Cd. 2817). 
ject of a Treaty Power, or with the authorization of such Magistrate.

(f) That in all cases in which the execution of a judgment, a search warrant, or other legal process involves the entry upon premises for access to which Consular intervention is necessary, such execution shall be carried out in the presence and under the direction of a police officer or officer of the Court who is the subject of a Treaty Power.

(g) That no sentence of death passed upon any subject or vrotected subject of a Treaty Power shall be carried into execution until one calendar month after the notification of such sentence to the Representative in Egypt of that Power, and that every such sentence shall be commuted to one of penal servitude for life if within that period such Representative makes a request to that effect.

(h) That every prison in which any subject or protected subject of a Treaty Power is confined shall at all reasonable times be open to the inspection of the Consular authorities of such Power.

It appears to me that, with these reservations, the power to pass criminal laws applicable to Europeans might safely be vested in the new [Legislative] Council, acting with the assent of the Egyptian and British Governments.

As regards jurisdiction in civil matters, I would propose that, upon the signature of a Treaty with the Powers giving effect to the arrangements set forth in this report, the system of quinquennial periods for the Mixed Tribunals should cease and determine, and that the present régime of those Tribunals should remain in force unless and until it is altered by legislation approved by the Council and promulgated by the Egyptian and British Governments.

It might be specifically stated that the present Judges of the Mixed Tribunals, who may desire to remain in the service of the Egyptian Govermment, should be entitled to retain their posts and present salaries, and that their services should be available in any Courts which may in the future be established.

A further point of much importance has to be considered. I have already suggested that a specific engagement should be taken by both the British and Egyptian Governments that every reservation in favor of British subjects should ennure for the benefit of the subjects of other Powers. It has, however, been pointed out ${ }^{1}$ that any general displacement of the present mixed law by English law would secure an effective preference for

\footnotetext{
${ }^{1}$ Report for 1904, p. 94. Note.
} 
British subjects without technically violating the guarantee to which allusion is made above.

There is not, indeed, the smallest likelihood that an attempt will ever be made under British auspices to effect any radical change in the civil and criminal laws, which at present generally obtain in Egypt, and which, after an experience of thirty years, have now taken root in the country. Nevertheless, some specific guarantee against any such change may not unreasonably be demanded. I propose, therefore, that both the British and Egyptian Governments should make formal declaration to the effect that they have no intention of changing the fundamental principles of the existing civil and criminal legislation, which will continue, as heretoiore, to be in general those of the European codes, and more especially the codes of the Latin nations, with such additions and modifications as experience may show to be best suited to the needs and conditions of the country. A declaration of this sort, coupled with the fact that no change will be possible without the consent of the majority of a Council, in which what, for the purposes of the present argument, I may term the Latin interests will be fully represented, will afford an effective and ample guarantee that no legislation will be undertaken which will be open to the objection indicated above.

I should add that I would propose to provide in the Treaty that all Judges, whether engaged in criminal or civil affairs, who are at present irremovable from their offices, should continue to enjoy such irremovability; and, further, that Judges, who may be hereafter appointed to any superior Court or Courts which may be established shall likewise be irremovable from their offices. The principle of irremovability should not, however, apply to a Judge's place of residence. 


\section{XI-REFERENCE TABLES}

\section{1-CONSULAR COURT REGULATIONS ${ }^{1}$}

\section{CHINA}

\begin{tabular}{|c|c|}
\hline J. W. Davis & $\begin{array}{l}\text { Jan. 2, } 1849 ; \\
\text { Sept. } 9,1850\end{array}$ \\
\hline P. Parker & $\begin{array}{l}\text { Mar. } 10,1851 ; \\
\text { Mar. } 1,1852\end{array}$ \\
\hline
\end{tabular}

R. M. McLane Dec. 5, 1854; Feb. 25, 1856

R. M. McLane

R. M. McLane

P. Parker

P. Parker

W. B. Reed

S. W. Williams

W. B. Reed

A. Burlingame

A. Burlingame

J. B. Angell

C. Denby

Aug. 25, 1854; July 15, 1856

Oct. 2, 1854; July 15, 1856

Mar. 8, 1856; Dec. 12, 1856

Mar. 4, 1857; Dec. 10,1857

Feb. 27, 1858; Dec. 27,1858

June 12, 1858 ; Jan. 26, 1859 Nov. 9, 1858; Feb. 6, 1860 Apr. 22, 1864; Dec. 4,1865 Apr. 23, 1864 . Dec. 4,1865 May 26, 1881; Mar. 22, 1882

Date of promul-
Sen. Ex. Doc. 72, 31st Cong., 1st Sess., p. 8-19. 'Procedure and appointment of clerks and marshals of consular courts, fees and forms. Sen. Ex. Doc. 43, 32d Cong., 1st Sess., p. 2-3. Control of seamen on shore leave, employment of Chinese and trading with Chinese.

Ho. Ex. Doc. 32,34 th Cong., 1st Sess., p. 3-4. Neutral conduct of individuals. (Published at the time of the Taiping rebellion.)

Ho. Ex. Doc. 125, 34th Cong., 1st Sess., p. 5-11. Collection of debts, and procedure.

Ho. Ex. Doc. 125, 34th Cong., 1st Sess., p. 7-15. Collection of debts, and procedure.

Ho. Ex. Doc. 11, 34th Cong., 3d Sess., p. 7-8. Exercise of judicial functions by vice-consuls and acting consuls.

Ho. Ex. Doc. 9, 35th Cong., 1st Sess., p. 2-3. Authority to hold court on board ship in the five ports during the hostillties between England and France, and China.

Sen. Ex. Doc. 11, 35th Cong., 2d Sess., p. 1-2. Assignments for the benefit of creditors.

Sen. Ex. Doc. 34, 40th Cong., 3d Sess. p. 1-10. Prohibition to navigate the Straw-shoe channel of the Yangtse river.

Sen. Ex. Doc. 7, 36th Cong., 1st

Sess., p. 1-2. Court fees.

Ho. Ex. Doc. 1, 39th Cong., 1st Sess., pt. 2, p. 414-5. Registration.

Ho. Ex. Doc. 1, 39th Cong., 1st Sess., pt 2, p. 415-21. Procedure and general, annulling earlier decrees inconsistent therewith.

Ho. Ex. Doc. 213, 47th Cong., 1st Sess., p. 1-3. Summons to absentee defendants in civil suits.

Sen. Ex. Doc. 65, 50th Cong., 2d g a tio n not Sess., p. 1-4. Court fees. given; Jan. $14,18 \leqslant 9$

1 The second column gives first the date of promulgation, second the date of submitting the regulations to Congress. See supra, p. 43-5, 53-4.

There appear to have been no regulations for other countries excepting Japan, which were as follows:

C. E. Delong Nov. 16, 1870; Sen. Ex. Doc. 25, 41st Cong., 3d $\begin{array}{ll}\text { Jan. 27, } 1871 & \text { Sess., p. 1-39. Procedure. } \\ \text { J. A. Bingham Jan. 27, 1881; } & \text { Ho. Ex. Doc. 1, 47th Cong., 1st }\end{array}$ Dec. 6, 1881 Sess., p. 690-1. Criminal penalties.

The regulations for Japan ceased to be of force July 17, 1899; see supra, p.183-8. 
C. Denby

C. Denby

E. J. Morris

A. Heard
Aug. 18, 1888; Jan. 14,1889

Sept. 15, 1897; Dec. 15, 1897
Sen. Ex. Doc. 65, 50th Cong., 2d Sess, p. 4-6. Permitting judgments by confession and prescribing forms for the same.

Sen. Ex. Doc. 32, 55th Cong., 2d Sess. Arrests and rendition of offenders.

\section{KOREA}

\section{2-OPINIONS OF ATTORNEYS-GENERAL}

Isaac Toucey.

Caleb Cushing

Caleb Cushing

Caleb Cushing

Caleb Cushing

Caleb Cushing

Caleb Cuishing

Caleb Cushing

J. S. Black

Edward Bates

G. H. TVilliams

A. H. Garland

O. W. Chapman (Acting)

W. H. H. Miller

W. H. H. Miller

P. C. Knox
5 Opln. Atty.Gen. $67-9$, Jan

6 Opin. Gen 59-60, Jun 28,1853

7 Opin. Atty.Gen.18-32, Nov 4, 1854

7 Opin. Atty.G e n. 186-229 May 25, 1855

7 Opin. Atty.Gen. 342-9, July 14,1855

7 Opin. Atty.G e n. 495-522 Sept. 19,1875

7 Opin. Atty.G e n. 565-7i, Oct. 23,1855

8 Opin. Atty.Gen. 380-7, Feb 11, 1857.

9 Opin. Atty.$G \in \mathrm{n}$. 294-5 Mar. 16, 1859

10 Opin. Atty. Gen. 250-2, May 12,1862 .

14 Opin. Atty.Gen. 522-4, Feb. 4,1875

18 Opin. Atty.G e $n$. 219-20, July $6,18 \delta 5$

19 Opin. Atty.$\mathrm{G}$ e n. $\quad 377-81$ Aug. 14, 1889 20 Opin. Atty.Gen. 92-3, May 7, 1891

20 Opin. Atty. Gen. 391-4, May 7, 1892

23 Opin. Atty.$\mathrm{G}$ e n. 608-14, Jan. 3, 1902
Place and manner of executing criminal penalties.

Expense of transferring native Chinese pirates to Hongkong lawfully payable from judiciary fund. Authority of consuls in nonChristian states to solemnize marriage.

History of the missions to negotiate treaties with the Barbary States, Turkey and China.

Fundamental differences between consular authority in Christian and non-Christian states explained.

General explanation of the treaty of 1844 with China and of the Act of 1848 with special reference to collection of customs in China, to the appellate jurisdiction of the minister to China, and the legal competency of vice-consuls to act judicially.

Jurisdiction by usage in clvil cases in Turkey.

Transfer to the United States of persons accused of crlme on the high seas.

Restriction of the judicial authority of the commissioner to China to the five ports.

Salary of a marshal began to run from time of entering on dutles preliminary to departure from the United States.

Sentences of imprisonment cannot legally be executed beyond jurisdiction of the court which pronounced them.

Authority to send an agent to try an offender in a barbarous country.

The President has no authority to order the removal of a prisoner from one prison to another.

Acting-consuls have no judicial authority.

A sentence of imprisonment in China can be served out anywhere in China.

Oath of a foreign subject appointed as marshal. 


\title{
3-LEGATIONS AND CONSULATES
}

\author{
I - CHINA
}

Peking

The Legation

The Act of June 30, 1906, creates a United States court for China. The sessions of this court are to be held in Shanghai, Tientsin, Canton, Hankau, and, at the discretion of the judge, in other cities where American consulates are located.

Amoy
Canton
Cheefoo
Clungking
Fuchau
Hankau
Mukden
Nanking
Niuchwang
Shanghai
Tientsin
Tsingtau

Seouil

Tangier

Casa Blanca Mogador

Maskat

Teheran

Tabriz

Bangkok

Constantinople

Athens

Cairo

Aleppo

Alexandretta

Alexandria

Assioot

Bagdad

Bassorah

Beirut

Damascus

Dardanelles

Harput

Jaffa

Jerusalem
Consul (class four)

Consul-general (class four)

Consul-general (class five)

Consul (class six)

Consul (class four)

Consul-general (class five)

Consul-general (class five)

Consul (class five)

Consul-general (class five)

Consul-general (class one)

Consul-general (class four)

Consul (class five)

II - KOREA

The Legation

Consul-general (class four)

\section{III - MOROCCO}

The Legation

Consul-general (class six)

Consular agent

Consular agent

\section{IV - OMAN (MASKAT)}

Consul (class nine)

V - PERSIA

The Legation

Consul (class seven)

$$
\text { VI - SIAM }
$$

The Legation

\section{VII - TURKEY AND EGYPT}

The Legation

Consul-general (class three)

Diplomatic agent

Agent and consul-general

Consular agent

Consul (class eight)

Consular agent

Consular agent

Consul (class nine)

Consular agent

Consul-general (class five)

Consular agent

Consular agent

Consul (class seven)

Consular agent

Consul (class seven) 


\section{Mersine \\ Mytilene \\ Port Said \\ Saloniki \\ Samsoun \\ Sivas \\ Smyrna \\ Suez. \\ Trebizond \\ Tripoli}

Zanzibar
Consular agent

Consular agent

Consular agent

Consular agent

Consular agent

Consul (class nine)

Consul (class six)

Consular agent

Consul (class eight)

Consular agent

VIII - ZANZIBAR

Consul (class eight)

\section{4-OPEN PORTS OF CHINA ${ }^{1}$}

\section{Port}

Niuchwang

Chinwangtao

Tientsin

Chifu

Kiauchau

Chungking

Changsha

Yochau

Ichang

Shasi

Hankau and "Yangtse

Stages"

Kiukiang

Wuhu

Nanking

Chinkiang

Shanghai

Suchau

Hangchau

Ningpo

Wênchau

Santuao

Fuchau

Amoy

Swatau

Canton

Kongmun and Kumchuk

Samshui and "West River stages,

Kiungchau

Pakhoi

Wuchau

Lungchau

Mengtsz

Szemao

Tengyueh

Kaulun

Isappa

Yatung
Province

Shênking

Chihli

Chihli

Shangtung

Shangtung

Szechuan

Hunan

Hunan

Hupen

Hupeh

Hupen

Kiangsi

Anhwei

Kiangsu

Kiangsu

Kiangsu

Kiangsu

Chêhkiang

Chêhiriang

Chêhkiang

Fukien

Fukien

Fukien

Kwangtung

Kwangtung

Kwangtung

Kwangtung

Kwangtung

Kwangtung

Kwangsi

Kwangsi

Yunnan

Yunnan

Yunnan

Kwangtung

Kwangtung

Thibet
Estimated Chinese Population (2904)

$$
\begin{array}{r}
50,000 \\
5,000 \\
750,000 \\
75,000 \\
\text { (Sma11) } \\
600,000 \\
230,000 \\
20.000 \\
45,000 \\
80,000
\end{array}
$$

870.600

36.000

122.000

270,000

167,000

651,000

500,000

300,000

260,000

80,000

8,000

624,000

114,000

48,000

900,000

55,000

5,000

30,000

20,000

53,000

12,000

12,000

9,000

11,000

(Small)

(Small)

(Small)

In addition to the ports named above the following are to be opened to trade under the British Treaty of September 5, 1902: Wanhsien in Szechwan, Nganking in Anhwei, and Waichau in Kwangtung; the following under the American treaty and the Japanese treaty, each of October 8, 1903: Mukden, Antung and Ta-tung-kau, all located in Manchuria.

\footnotetext{
1 Statesman's Year-book, 1906.
} 


\section{INDEX}

Abd ul Messih v. Farra, cited, 92 note 2.

Aberdeen, Lord, on summary nature of extraterritorial criminal jurisdiction, cited, 98 note 2. Absentees, Turkish tax on, 136.

Abuse of extraterritorial privileges, results of, 89 .

Acting consuls have no judicial authority, 57.

Actor sequitur forum rei, rule of, 151.

Acts of Congress, see Congress, Acts of.

Adams, R., Representative, improvement of consular jurisdiction, 86.

Admiralty jurisdiction, 43, 101.

Agency theory of extraterritorial jurisdiction, 66-7.

Aintab, disturbances at, 115 .

Aix, French court of appeals at, 74, 151.

Alcohol, Turkish internal tax on imported, 135 .

Alexandria, municipality of, 158 note 2

Alexius III, chrysobulum of 1199,3

Algiers, treaties with, 19-20; milltary occupation by France, 20 Mohammedan law retained in, 178; relinquishment of jurisdiction in, 178; departments of France, 178 .

Aliens in service of oriental governments, 86-7.

Allegiance of seamen, theories of personal, and territoriai, 87.

American employees of oriental governments, 86-7: nationality, proof of, $81-3$; seamen, 87 .

Ancient usages, effect of in Turkey, 15-6.

Andronicus II, aurea bulla of 1304, 3-4.

Angell, J. B., on privileges of dragomans, 84; secured exemption of Chinese converts from taxes for pagan festivals, 122 .

Aoki. Viscount, in negotiations for abrogating extraterritorial jurisdiction in Japan, 186-7.

Appeals from consular courts, 49$50,58-9.613 ;$ under the British system, 72: under the French system, 74
Appropriation, annual diplomatic and consular, 1905, 198 note.

Arbitration of the Cheek claim against Siam, 148 note $1,162$.

Armenians, emigration of families of, 79; indemnities for injuries to citizens at times of disturbance, 150; naturalization, effect of, on rights in Turkey, 79,100 ; protection of citizens during disturbances of $1895,117$.

Arrests, in order to try, 103; exemption from, 59; see Capitulations.

Article IV, treaty of 1830 with Turkey, origin of differences concerning, 23; translations of, 24 , 25: concessions proposed and declined, 25; similar language of other treaties, 26; Secretary Blaine's instructions of Dec. 22, 1890, 29; see Criminal jurisdiction.

Assessors, the system of, developed by France, 73; see Assoclates.

Assignment of claims by natives to foreigners, 146-7.

Associates to consular judge, provision for in the Statutes, 47, 48; right of to separate in the course of a trial, 102

Asylum not to be given native offenders, 103-4.

Attorneys, foreign, appearing in consular courts by courtesy, 62 .

Audience question in China, 60 note; in Japan, ibid.

Austria, capitulations of 1718,13

Austria-Hungary, treaty of 1869 with Japan, 17, 184.

Avedikian, dragoman, protection of, 84 note 1 .

Bailo, Venetian at Constantinople, 13.

Baldwin, J., opinion on constitutionality of consular jurisdiction, 65.

Bankruptey, undeveloped law of, 146.

Barbarous countries, jurisdiction in, $40,42$.

Barbary States, first American treaties with, 19; treaties now in force, 20; early piracies of, 7 .

Barcelona, privileges of in Egypt, 8. 
Barclay, T., negotiation of early treaties with the Barbary States, 19.

Bayard, T., on nationality of children of citizens in Smyrna, 90: on effect of marriage upon nationality, 94; approval of Mr. Straus's protest against certain Turkish regulations, 115; on legality of the Shanghai municipal regulations, 171; on continuing protection of Americans under German military occupation of Samoa, 180; on a regulation for consular courts in China, limiting actions, 55 note 2 ; on nationality of Chinese wives of Americans, 79 note 7 .

Beale, T., secured real property privileges for American citizens in Persia, 134.

Beirut, American Medical College, 113-4.

Berthemy convention with China, $119,127$.

Bethell, Re, cited, 92 note 2.

Biddle, Capt. J., negotiation of treaty of 1830 with Turkey, 21-2.

Bingham, J. A., declined to give opinion in a case unless upon appeal, 62; jurisdiction of a deserting seaman, 87 note 3 .

Black Sea, privileges in, negotiations of $1830,21,22$.

Blaine, J., interpretation of Art. IV of treaty of 1830 with Turkey, 25 ; opinion on changes desirable in American consular jurisdiction, $74-5$.

Bombay, British court of appeal at, 72 .

Borneo, United States treaty with, 39; British and Dutch protectorates in, 181 .

Bourée, M., opinion on effect of the real estate protocol of 1874 , $30,132$.

Bradish, L., early treaty negotiations of, with Turkey, 21.

British foreign jurisdiction, 69-72; authorities on, cited, 69 note.

Brown, J. P., correspondence describing jurisdiction in Turkey under extraterritorial treaties, 28-9.

Buckley, J., trial of, 64 note, 102

Bulgaria, jurisdiction in, under the treaty of Berlin of 1878,190 .

Burgess, J., opinion on the constitutionality of consular jurisdiction, 66-7.

Burgevine, General, in Taiping rebellion, 100 .

Burlingame, A., inltiated a coöperative policy in China, 159, 165; religious toleration under the treaty of $186 \mathrm{~S}$ with China, 119.

Byzantium, 6; see Constantinople.

Cadi, functions of, under capitulations of 1535,9 ; contracts under seal of capitulations of 1675,12

Caisse de la dette of Egypt, erisis concerning the international tirbunals, $15 \%$

California, early trade with Japan, 26 ; former appellate jurisdiction of the circuit court of the United States in, 49, 63; appellate jurlsdiction of the circuit court of appeals, 50.

Canter's case, cited, 68 note 1.

Canton, duties on goods in native junks, 137; foreign settlement at 165: likin tax on petroleum at, 139.

Capital offenses, jurisdiction of, 48; pardon of offenders by commutation of sentence, 49

Capitulations, origin of the term, 3 ; obtained by Venice in 1199,3 by Genoa in 1304, 3; by Florence in 1445; by Pisa in 115i; by Marseilles and Barcelona, 7-8; by France in 1535, 8-9; in 1569, 1604 and 1673,10 ; in $1740,10-1$; by England in 1580 and $1675,6-7,11-3$; by Austria in 1718,13 ; by Russia In 1783; by Holland in $1612 ; 12$ note 1 ; continuing force of the capitulations, 14; la question des capitulations, 188-92; see Turkey. treaties.

Carpenter, MI., Senator, opinion on constitutionality of consular jurisdiction, 63 note 1 .

Cavass, immunities of, 84-5.

Ceremonial, see Audience question.

Chargé d'affaires, whether judicial functions may be exercised by, 56 .

Cheek, M. A.. claim against Siam, 148 note 1, 162.

Children boln of American parents in the Orient, status of, 90-1.

China, adoption of western law, 193: American trade with, early in the nineteenth century, 31-2; claims against, for indemnities, 147-9; commercial regulations upon investment of foreign capital, 142; financial conditions of as related to foreign jurisdiction, 147: hong system of early trade, 31: Imperial Maritime Customs, 137-8; interior, rights of residence in, 120; joint-stock companies, privileges of $14^{2}$; jurisdiction of in the leased areas, 176-7; and in Shanghai, 171; and in other foreign settlements, see Foreign settlements; leased areas of $176-7$; likin, abolition of, 13S-40; manufacturing privileges of, 142-3; mines, concessions and regulations, 143; mixed cases in, trial of, 158-62; monopolies in, granting of, to foreign companies not permitted, 144; native converts, relation of, to missionaries, 121-2; navigation of the Yangtse river, 141: railways, concessions and regulations, 143-4; real property in the open ports, 125-6; and in the interior, 126-8; and acquisition by special grant, 127: and by missionary societies under the American treaty of 1903. $127-8$; and irregular methods of acquiring, 126 ; rule of lex loci, 97; succession to, 97; religious toleration in, $109,11 S-20$, 124: relinquisliment of consular jurisdic- 
tion in Japan, 194; stock companics, regulation of, 142 ; succession to real property in, 97; treaties with the United States, of $1844,32-3$; of $1858,34-5$; of 1868 , 119 ; of 1580,35 ; of 1894,83 ; of 1903 , $35,19^{\circ}, 193$; with Great Britain of $184:$ and 1843,31 ; of 1858,126 ; of 1902,137 note 3,142 ; with France of $1860,126-7 ;$ convention with France of $1865,12 \%$; with Japan of $1895,140,142-3$; Lnited States court for China, 41, 43, 48, 50. Appendix IIl-2.

Churches, use of dwelling houses as, 111.

Circuit court of the Inited states in California, former appellate jurisdiction of, 49,63; circuit court of appeals, ninth judicial circuit, appellate jurisdiction of, 50.

Citizenship, see Nationality.

Claims against China, 147-9; against Japan, as set-off, 161; against Siam, arbitrated, 145 note 1. 16:; against Turkey, 149-50.

Collection of debts in Turkey, 146.

Comanos, Vice Consul-General, sitting as judge in Mirzan trial, 103.

Comity, acts of, see Friendly offices.

Commerce, power to regulate, a ground for jurisdiction, 68 .

Commercial privileges in China, $140-5,141$ note 1 ; in Turkey, $145-6$, 141 note 1.

Commisions, mixed, trial by, in Turkey, 151

Common law, to be enforced in consular courts, 43; meaning of the term in relation to American foreign jurisdiction, 51; opinion of Chief-Justice Marshall, 52, 52 note 1 ; opinion of Attorney-General Cushing, 52-3.

Companies, see Joint-stock companies.

Congo Free State, jurisdiction in, $39-40$.

Congress, Acts of, of Aug. 11, 1848, 41; of June 20, 1860, 41; of July 1, 1870,41 ; summary of Rev. Stat., Sec 40\$3-4130, 41-9; of A pril 5, 1906, and of June 30,1906 , see Appendix III-1-2; the Davis-O Connor bill for revision of Rev. Stat., Sec. $4083-4130,76$; legislation of 1906,77 ; annual Diplomatic and Consular Appropriation Act, June 16, 1906, 98 note 1.

Congress of Paris of $1 \$ 56$, proposal to revise the capitulations, 188.

Constantinople, under Greek emperors, 36: captured by the Turks in 1453, 5-6; effect of military régime near, in 1887, 180; British court of appeal, at 72.

Constitutionality of foreimn jurisdiction in the Orient, 6t-9.

Consul, statutory meaning of the term, 45; immunities of, 59; relations with local authorities, 59; nationality of, 11; relations to other officials, 45, 5s-9; vicissitudes of consuls in early relations with the Orient, $5,6$.

Consular courts, what law enforceable in, 43.
Consular districts, $46,60$.

C'onsular judge, jurisdiction of when sitting without associates, 46; with associates, 46-7; relations to executive superiors, 57-8.

Consular jurisdiction, inuprovement of, desirable, $74-5,196$

Consular officers, wnom the term includes, 45,56 .

Consulates, districts pertaining to, 60

Contraband, trade in, in China, in $1855,102$.

Convicts, care of, 50, 99 note 1 104-7.

Coolie trade, a criminal offense, 99. Coöperative policy in China, 159 , 165.

Copyrights, 140 .

Costa, Dragoman, 84.

Counter claims in mixed cases, 161

Crane, Capt. W. M., in negotiations with Turkey, 21.

Crete, l'égime of capitulations in, 190.

Crimes, acts indictable under the treaties, 98.

Criminal jurisdiction, 98-108: under the early capitulations, $3-4,9,10$; under the capitulations in favor of France of 17t0, 11; under those in favor of England of 16:5, 12-3; under Article IV of the American treaty of $1830,23-6$; existing practice, 26-7; letters of Consuls Brown and Dainese concerning practice about 1850, 28-9; in China at time of negotiating the American treaty of 1844, 33; transfer of offenders in China, 104; settlement of minor cases out of court, 46.

Cromer, Lord, Report on Egypt 15s. Appendix

Crusades, jurisdiction of consuls in Syria during, 4.

Cubans, friendly offices toward, $\delta 9$.

Cushing. $C_{\text {. }}$, negotiation of treaty of 1844 with China, 32-3; opinion upon jurisdiction in Turkey, 28; opinion on meaning of the term common law in reference to foreign jurisdiction, 51-2; approval of municipal regulations for Canton, 165

Customary rights, see Ancient usages.

Customs, stipulations regarding usually" contained in earlier oriental treaties, 2; settlement of disputes concerning. in China, $137-40$; in Turkey, 135

Cyprus, régime of capitulations in, 190.

Dainese, $F$, letter in regard to criminal jurisdiction in Turkey, 28

Dainese $v$. Hale, 51, 58 note 3.

Danish Great Northern Telegraph Company in China, 144-5.

Danubian principalities, 182-3, 190.

Davis-O Connor bill, 76 .

Debts, collection of in China, 146 . in Turkey, 146.

Decatur, Commodore, in early negotiations with Barbary States, 19. 


\section{INDEX}

De Long, C. E., published consular regulations for Japan, 54.

Denby, C., on validity of marriages with foreigners in China, 94; on responsibility of provincial governors to protect missionaries, 124; on Chinese law, 193-4.

Denby, E., Representative, improvement of consular jurisdiction, 77

Department of state, relation to, of consuls when acting as judges, 58; without authority to revise a consular court judgment, 62 .

Deportation from Japan, as a penalty, 105-6; for trial under the British system, 104.

Desertion of seaman, effect on his privileges, 87 note 3 .

Dickinson, C. M., on collection of debts in Turkey, 146.

Dinkelle, commutation of penalty of 107 .

Diplomatic correspondence in settlement of certain claims, 161-2.

Districts, consular, 60 .

Divorce, 95.

Domicil (dwelling) inviolability of, $112,115,118$; (legal) of origin retained, 92.

Dragomans, inmmunities of, 84-5; see Protected persons.

Dwight, $H$. O., on missionary book trade and schools in Turkey, 113 note 2,115 note 1 .

East India, portions of native law retained, $1 \%$.

East India Company, early jurisdiction in Japan, 69.

Echelles du Levant, origin of the term, 73.

Egypt, influence of Great Britain in. 159 ; international tribunals of 151-8; their origin, 153-5; their activity, 155; their organization and powers, 155-6; the crisis of 1880, 156-7; of 1896, 157; larger extraterritorial privileges in, than in Turkey proper, 27: relations of, to Turkey, 154; judgments against government of, 156-8; impracticable to have courts in China like the international tribunals, 159.

Employees of foreigners in China, 85-6; foreigners serving native governments, 86-7.

England, see Great Britain.

Evarts, W. M., instructions by, in Mirzan trial, 103.

Execution of judgments, 50 .

Executive, functions of, in foreign jurisdiction, 49, 56-9.

Executive Order of June 27, 1906, 77, Appendix III-3.

Exemption from arrest, 59; see Capitulations.

Exequatur, under capitulations of 1535. 9: relating to the leased arcas in North China, 176-7.

Fx parte O'Neil. 62.

Expatriation, of Americans in Oriental countries, 91; of Turkish subjects, effect on real property rights, 133.

Expulsion from Turkey, 106-7.

Extradition, consuls have no power to extradite, 104; American treaties of, 105; British methods of, $10 \%$.

Extrater'ritoriality, not formerly regarderl a dispalagement to sovereignty, 17; adaptions of, when introduced into China, 15. e2-3; distinctions between forms of in Turkey and China, 15, 161; reasons for maintaining in Turkey, 14, 188-92; stipulations regarding, usually contained in earlier oriental treaties, 2.

Field, J., opinion in In re Ross, 66.

Filipino seamen, jurisdiction of. $s=$ note.

Fish, H., on regulations and procedure, 55, 95.

Florence, capitulations of 1145 in tavor of, 5

Forbes v. Scannel, 51, 65.

Foreign jurisdiction, British Acts of 69-71: Orders in Council, relating to, 71-3; of France, 72-4.

Foreign municipalities, French system of government of, 72-4.

Foreign quarters in cities of the Levant, ?

Foreign settlement at Shanghai, see Shanghai; elsewhere, 163-

Foreigners as seamen, jurisdiction of, 87 .

France. capitulations in favor of of $1535,8-9$; of 1569,1604 and 1673 10; of 174, 10-1; government of foreign municipalities, 72-4; development of assessor system, 73; separate municipality in shanghai, 165-6; treaty with China of $1860,1: 6-7$; relinguishment of jurisdiction in Japan, 194: military occupation of Madagascar, 179-80; of Algiers, 178; treaty of 1886 with Korea, 125: coniention with China of 1865.127 ; ordinance of 1781, 129; real estate protocol of 1868 with Turkey, 130.

Francis I, obtained capitulations of $1535,8-9$.

Franks, origin and significance of the term. 8

Fraser, H., in negotiations between Great Britain and Japan, leading to treaty of $1894,186$.

Frelingluysen, F on desiralibito of further legislation on consi"? jurisdiction, 74; referred to Co.1. gress question of relinquishing jurisdiction in Tunis, 181.

French foreign jurisdiction, 72-4.

Friendly offices, mutual dmerican and British, 57, 88; to Chinese, 88 ; to Cubans, s9: to Japanese. ss; to Swiss, 8s: of Russians to French in Clina. 175.

Furitives from justice, see Extradition.

Galata. 3.

Gargiulio, Dragoman, 80 note 2. Genoa, capitultions of 1304 in favor of 3.

Germany, lease of Kiachow, 176 : separite concessions at the open ports, 166: jurisdiction of consulgencral of, in clina, 56 note 1 ; 
nationality of Chinese wives of Germans, 79 note 7 ; trial of American citizen by a German acting consul, 57.

Gibraltar, British court of appeal at, 72 .

Great Britaln, capitulations of 1580 and 1675 in favor of England, 6-7, 11-3; Acts of Parliament examined by a committee of Congress, 41; foreign jurisdiction of, $69-72$; treaty with Turkey of $1890,98,135$; with the United States and Great Britain on Samoa, 39, 180; treaty of 1858 with China, 126 ; real estate protocol of 1868 with Turkey, 130; influence in Egypt, 158; negotiations leading to abrogation of extraterritoriality in Japan, 186-8; treaty with China of 1842,31 ; of 1843,171 ; of $185 \delta, 126$; of 1902,119 142: colony of Hongkong, 164-5: methods of extradition, 105 ; treaty of 1857 with Persia, 18; rights of British Jews in Turkey, 80; treaty of 1883 with Korea, 125.

Greece, extraterritorial rights in Turkey, 182; arbitration with Turkey following the war of $1897, \quad 189-90$.

Gresham, T. Q., treaty of 1894 with Japan, 188

Gurdjian, instructions in the case of, 29.

Hankow, separate German concession at, 166 .

Hankow-Canton railway, 144.

Hannen, Sir Nicholas, arbitration by, 162 .

Harbor regulations, force of, $98-9$.

Harpoot, property destroyed at, 116.

Harris, T., negotiation of treaties with Japan and Siam, 37-8; honored in separate audience, 58 llote 2.

Hart, Sir R., administration of Imperial Chinese Customs. 137.

Hawail. no extraterritoriality in, 39, 194; relinquishment of jurisdir:tion in Japan. 194.

Hawaii v. Mankichi, cited, 68 note 1.

Hay, J., telegram of July 3, 1900, relating to China, 149.

Heard, A., regulations for Korea, 54.

Hili, Senator (of Georgia) on constitutionality of jurisdiction, 64 note 1.

Hoar, Senator, on constitutionality of jurisdiction, 64 note 1 .

Hong system in China, 31.

Hongkong, British supreme court of. 72; extradition between, and Clina, 105, 164-5.

Humphreys, Col. David, 19.

Imperial Japanese Govt. v. P. and O. Steamship Co., 161.

Imprisonment, for crime, where to be made, 107

Indemnities, paid by China, 147-9; by Turkey, 116-7, 148-50; by the United States, 162 .
Inheritance of personal property. 95; see Succession.

Inland waters of China, navigation of, 141-2

Inouye, Count, in Tokio conferences of 1886, 185 .

In re Ross, 51, 66, 87, 103; see Ross.

In re Stupp, 64 note 2

Insurrection, capital offense to join in, 100.

International law, effect of in consular courts, 50 .

International tribunals of Egypt, see Egypt.

Interpreters, see Dragomans, and Appropliation.

Ionian Islands, jurisdiction in, 190.

Italian cities, privileges of in the Levant, 2-5.

Ito, Marquis, in embassy of 1872 to the West, 184

Iwakura, Prince, in embassy of 1872 to the West, 184.

Jackson, trial of, 60 note 2 .

Japan, Americans residing in. urged further legislation on extraterritorial jurisdiction, 75 note 1 ; deportation from, of criminal offenders, 105-6; obligation of foreigners to comply with local police regulations, 99; early American relations with, 35-8; growth of modern political institutions, 183-5; international tribunals for, proposed and declined, 158; negotiations leading to relinquishment of extraterritorial privileges in, 185-8; basis of judicial autonomy, 186-7; jurisdiction of, retained in leased areas of China, 177 ; separate concessions in certain open ports of Chila, 167; real property interests, foreigners not permitted to acquile, Izs; growth of usages in connection with extraterritoriality, 15 note 2 ; riglits of manufacturing in China, 140.

Japan v. Pacific Mail Steamship Co., 63 note 3 .

Japan v. P. and O. Steamship Co., 161.

Japanese spies at Shanghai, trial of, $174-5$.

Jews, in Turkey, maltreatment of 80-1; real estate privileges, $80-1$. 133: restrictions upon travel, so-1. in Persia, protection by government of, 118 .

Joint-stock companies, jurisdiction of, 86 ; regulation of, in China, 142; in Turkey, 145.

Judgments, execution of, 50 ; see Associates.

Judicial functions, offices to which pertain, 45 ; not to be exercised by 'acting' consuls, 57.

Jury, clain of right to trial before 66,102 .

Kiaochow, jurisdiction in, 176

Kimberley, Lord, treaty of 1894 between Great Britain and Japan, 187. 
Kirchwey, G. W., opinion as to jurisdiction of foreign seamen, 87 note 3.

Kongo, see Congo.

Koran, influence of, on political institutions in Turkey, 191.

Korea, treaty of IS82 with the United States, 38-9, 192; missionary privileges in, 124-5; treaty of 1856 with France, 125; of 1883 with Great Britain, 125.

Kowloon, British, jurisdiction in, 176.

Kurino, S., treaty of 1894 between the United States and Japan, 188.

Kutschuk Kainardji, peace of, 14 .

Land, see Real property.

Land regulations, at Canton, 165; at Shanghai, 167-70; at Hankow and Tientsin, 166; see Open ports.

Leased areas in China, jurisdiction suspended in, 176-7; claim of Japan to retain jurisdiction, 177.

Legislation, see Congress, Acts of; and Regulations; and France; and Great Britain.

Lew Chew Islands, treaty of 1854 with, 37.

Lex loci. rule of as to real property, 97, 128

Li Hung Chang, aid in negotiation of treaty with Korea of 1882,38 ; military escort of, not admitted to the Shanghai foreign settlement, 171 note 3 .

Lodge, H. C.. Senator, improvement of consular jurisdiction, 77 .

Macao, Portuguese colony of, 164,

Macdonald v. Anderson, 97, 123 note 2.

Madagascar treaties of 1867 and 1881, 38; became a French colony and jurisdiction in. relinquished 179-80: effect of military occupation on jurisdiction, 179; native law and courts in 178-9.

Mahoney v. U. S., cited, 20 note 2.

Malta, Turkish consular jurisdiction in, under British treaty of 1809. 18; Pritish court of appeal at, 72 .

Maitass v. Maltass, cited, 92 note 2.

Manchuria, effect of occupation of, 180.

Manufacture in China by foreigners, rights of, 142-3; taxation of 140; nission stations not to engage in, 121 .

Marash, invasion of domiciliary rights at, 112, 115; property destroyed at. 116.

Marriage, 92-4; solemnization of, according to the lex loci, 93-4; consuls not to issue licenses to marry, 93; consular certification of, 93 ; with foreigners, effect on nationality, 94-5.

Marseilles, privileges secured by, in Egypt, 7-8.

Marshals of consular courts, 98; annual appropriation providing, 98 note 1 ; execution of judgments by, 50; justiciable in consular courts, 62-3; office in China under Rev. Stat., Sec. 4111, abolished, 50.

Marshall, J., on meaning of the term common law under federal jurisdiction, 51-2, 52 note 1 .

Marsovan College property of destroyed, 116.

Martin, W. A. P., assistance as interpreter, treaty of 1858 with China, 34 note 1 .

Maskat, treaty of 1820 with, 20.

Matrimonial causes, 92-5.

Mavroyeni Bey, interpretation of Article IV of the treaty of 1830 with Turkes, 25.

Maynard, H., on method of solemnization of marriage between foreigners in Persia, 94.

McCondrill, trial of, 87 note 3 .

McLane, R. M., regulations regarding neutrality in China, 101.

Medicine, licenses of graduates in, in Turkey, 113.

Meiklejohn v. Gring, 54 note 3,62 note 1 .

Mexico, relinquishment of jurisdiction in Japan, 194.

Military occupation, effect of, on jurisdiction. in Madagascar, 17980; in Samoa, 180; in Turkey, 180.

Military service for foreign power, effect on jurisdiction, 85,101 .

Mines in China, concessions and regulations, $1 \mathrm{13}$.

Miinors, nationality of children of foreigners in oriental countries, 90-1.

Minister, significance of the term in the statutes, 45,56 ; jurisdiction of, 48,62 .

Mirzan, trial of, 103; commutation of penalty of, 107 .

Missionaries 108-25. effect of prolonged residence in the Orient upon nationality of, $90-1$; and effect $n f$, on nationality of children of $90-1$; non-religious policy of the United States, 108-10; citation of correspondence relating to rights of, 110 note 1 ; rights in the interior of China, 120-1; of Turkey, 111; domiciliary rights of, in Turkey, 112; real property rights of, in China, 127-8; in Turkey, $111-2$; real property rights acquired in name of native not easily protected in Turkey, 112; in China, 121; book trade of, in Turkey, 114-5, 115 note 1; schools of in China, 121; in Turkey, 111-3. 113 note 2: native converts and helpers, relations with, in Turkey, 115; in China, 121-2: use of dwelling houses as churches and schools, 111; privileges in China do not include rights of pursuing commerce or industry, 121 ; responsibility of provincial governors of China to protect, 123-4; in Korea 124-5: in Siam, 125: see Religious toleration.

Mitsu-Bishi Mall Steamship Co. v. Pacific Mail Steamship Co., 63 note 3 .

Mixed cases, jurisdiction of, in Turkey, 151-3, 161; in Clina, 35 
156-60, 161; between foreigners of different nationalities, 160-1; dlplomatic correspondence in cases of grave consequences, 161-2; arbitration of the Cheek claim against Siam, 14 s note 1,162 ; under the capitulations, $3,4,10,11$; in Persia, 45: see Egypt.

Mob violence, redress for injuries by, $116-7,148-50,162$.

Mohammedan law, retention of portions of, in Algiers, 178; in East India, 178; in Madagascar, 175-9; in Turkey, 191 .

Nonopolies, in China, granting to foreign companies not vermitted, 144; petroleum wareliouses in 'Turkey, 145.

Morgan, Senator J. T., improvement of consular jurisdiction, 77.

Morocco, treaties with, 19-20; convention of the power's of 1880 relating to protégés, 20; influence of rance in, 20 .

Morris, E. J., interpretation of Art $1 \mathrm{~V}$ of treaty of 1830 with Turkey, 23.

Most-favored-nation clause, effect of on extrateritorial privileges, 16-7; effect of Austro-Hungarian treaty of 1869 with Japan, 17; British jurisdiction under such a clause in a treaty of $185 \%$ with Persia, 17.

tivilk lands, 129.

If inicipalities, foreign, French svetem of, 73; in China, 163-7; see Silianghai.

Murder, death penalty for, commuted, $107-8$.

Niverat, see Maskat.

Yacionality, 78-91; scope of the term in foreign jurisdiction, is: see Naturalization, Protected persons, Passports, Dragomans, Seamen, Friendly offices, Expatriation.

Native converts, protection of, 86 , 121-2.

Native teachers, 115.

Native officials, visé of passports by, 82.

Naturalization, 78-80; equal rights of naturalized with native citizens, 78-9; policy of Turkey against unauthorized, 79; British Naturalization Act of 1870,79 rights of families of naturalized husbands or fathers, 79; defective, 80.

Navigation of inland waters, 141.

Navoni. N., Dragoman, treaty of $1830,22$.

Nee Chang Mow v. George and George, 63.

Neutrality, regulations to prevent abuse of in China, 101; of Shanghai, $172,174-5$.

New York Life Insurance Co., privileges of in Turkey, 145.

Nubar Paslia, origin of the international tribunals of Egypt, $154-5$.
Offenses, criminal, $97-108$; political $100-2$, 106- 7 ; under treaties of extraterritoriality, $98-9$.

Offiey, D., in early negotiations with Turkey, 21.

Okuma, Count, negotiations with Great Britain for abrogation of extraterritoriality in Japan, 186.

Olney, R., on responsibility of the 'Turkish government for acts of revolutionaries, 116-7; on military occupation of Madagascar as lnsufficient ground for cessation of consular jurisdiction, 179.

O'Neil, Ex parte, 62.

Open ports of China, 31, 35, 163, Appendix XI-4.

Oriental domicil, not acquired by westerners, 92.

Ottoman Empire, see Turkey.

Pardons, power to issue vested in the President, 107; instances of commutation of death penalties, $107-8$.

Parker, P., inspection of consulates, 60 note 1 ; court held by, at Macao, 54 note 4 .

Passports, 81-2; teskerehs, 81; travel certificates, 82 ; visé by native officials, 82 ; under the capitulations of 1749, 11; under the capitulations of $1783,14$.

Patents, 140.

Peking, legation guards, 85 note 3 .

Penalties, place of serving, 107.

Pera, see Galata.

Perry, Commodore, treaties with Japan and Lew Chew, 36-7.

Persia treaty of 1856 with the United States; of 1828 with Russia, 17; of 1857 with Great Britain 17: convention of 1875 with Turkey, 1s: mixed cases in, trial of 45; missionary privileges in, 118 asylum in, customary rights of, 118; real property rights in, 118, 134.

Personal allegiance, theory of $17-18,66-7$.

Personal property, inheritance of, 95-6.

Petroleum, likin in China, 139; warehouse monopolies in Turkey, 145.

Petty offenses, 98, 108 .

Pigeon v. Issavardens, cited, 151. note 1.

Ping-On v. Blethen, 63

Pisa, capitulations of 1154 in favor of, 5 .

Police regulations, local, effect of, $98-9$.

Political offenses, 100, 106, 172-6.

Port Arthur, jurisdiction in, 176-7.

Porter, Commodore D., ratification of treaty of 1830 with Turkey, 23.

Portugal, colony at Macao, 164; treaty of 1843 with Turkey, 26.

Postal privileges, in Turkey, 145-6: in China, 146.

Potter v. Insurance Co., cited, 51 note 1.

Pradier-Foderé, P., on existing practice in criminal jurisdiction in Turkey, 27 note 1 . 
President of the Lnited States, power to pardon, criminal offenders, 49 ; instances of commutalion of sentences, 107 .

Press, rights of, in Turkey, 114-5; Supao case in Shanghai, 172-1.

Prisons, need of in China, 35 note 1; authority to provide, 49; use of local prisons, 98; annual appropriation for rent and keeping of, $9 \mathrm{~s}$ note 1 .

Privileges, commercial. 140-50; see Missionaries, Real property.

Privy Council, British, appeal to, 72.

Procedure, regulations of issued by ministers, 54 ; in trial of criminal offenders, $102-3$.

Progress of oriental nations, 1-2, 195-6: of Japan, 183-\$.

Protected persons, restrictions of the protégé system in the Levant, 11, 12, 83-5; dragomans, 84; Chinese employees, 85-6; foreigners in the employ of native governments, 86-7; strict rule of nationality in China, 16; see Scamen, Friendly offices, Native converts, Native teachers.

Protectorates, jurisdiction under, $180-2$.

Protégé system in the Levant, \$3-5; no similar system in China, 89

Protocol, real estate of $1874,30-1$, 131-3.

Quarantine regulations in Japan, effect of, 99; Sheppard, E. T., on, 99 note 1 .

Railways, concessions and regulations, in China, 148; in Turkey, 133,141 note 1 .

Rasmussen v. $T$. S., cited, 68 note 1.

Real property rights, in China, 119-21; concessions at the open ports, 125-6: undesirable methods of acquiring, 126; interpretation of the French treaty with China of $1560.126-7$; in Turkey, 19S-34; Turkish law of. 129-33; former claim of jurisdiction over holders of, 129 ; rescript of 1867,130 ; protocol of 18it. 131-?; appeals from decisions in Turkish courts, 133-4. privileges in Japan restricted to renting in open ports, 128; privileges in Persia. 134; succession to real property, $96-7$; lex loci to be applied, 97, 12 .

Re Pethell, cited, 92 note 2.

Reciprocity, in granting extraterritoriality, 18 ; in relinquishing jurisdiction in protectorates, 182.

Reed, W. B., treaties of 1557, 1858, with China, 34.

Referees, settlement by decision of, 46 .

Registration of citizens and protégés, S3.

Règlement d'organisation judiciaire, 156

Regulations issued by the ministers, statutory provisions for, $43-5$; to be laid before Congress,
44; nature of those that have been issued, 54; opinion of Secretary wish on restricting them to procedure, 55, 95.

Reid's case, legality of Shanghal municipal ordinatuces, $170-1$.

Reis Iffendi, nesotiation of treat of 1830 with Turkey.

Pcligivus toleration, in China, 109, 118-20, 124; in Turliey, 169-11; early Noslem intolerance, 5-7.

Relinruishinent of jurisdiction, 17s96: treaty of 15s2 with Korea, 39. 192: in Slam, 193.

Residence in interior, 111, 120; effect of prolonged, in Orient, on nationality, 90.1.

Revised Statutes, Sec. 4083-4130. summary of $11-50$.

Rinind. C negotiation of treaty of 1530 with Turkey, 21-3.

Roberts, E.. Captain. 20.

Rockhili. W. W., on responsibility of Chinese provincial yorernors for protection. $23-4$; pleninotentiary in negotiatiuns of 1930 at Peking, 149.

Romnn law, adaptations of, in early capitulations, 3 note 1 .

Ross, In re, 51, 66, 87, s7 note 3 , 103; see Ross.

Ross, trial of at Yokohama, 61: commutation of penaity of, 107 .

Roumania, relinfushment of juristiction in, 1s2; relations with Turkey, 190

Rules $n t 186$ for settlement of customs disputes in China, 137; of 1902, same, 137-8.

Russia capitulations of $17 \AA 3$ in favor of, 13-4; early privileges in China, 15, 33; friendly assistance in negotiating treaty of 1820 with Turkey, 21; treaty of 1839 with Turkey granting criminal jurisdiction. 26; coöneration in China in 1s5s, 34; lease of Port Arthur. 176 .

Saĩgon, French court of appeal at, 74

Salisbury, Marquis of. negotlations for abrogation of extraterritoriality in Jatran, 1S6-7; continuance of international tribunals of Egrpt, 15s.

Salonica, rights of a dragoman at, 84

Samoa, treaty of $187 \mathrm{~s}$ with, 39 ; effect of German necupation on jurisdiction in, 1so; partition of the islands, 39: relinquishment of jurisdiction in certain islands, 39.

Samos, régime of the capitulations in, 190.

Saracen caliphs, capitulations granted by, 4-5.

Shablenders, rights of Turkish in Anstria, 13: in Malta, 18.

Schools, missionary in china, 121 in Turkey, dmolling houses used as, 111-2; reguliztions of Turkish government for, 112-8; $H . \quad O$. Dwight on, 113 note 2: licenses of graduates in medicine, 113-4; see Native converts, Native teachers, Missionaries. 
Schufeldt, Commodore, negotiation of treaty of 1882 with Korea, 38. Seamen, foreigners engaged on American ships, 87.

Secretary of legation, whether authorized to exercise judicial authority, 56.

Secretary of State, official relation to Consuls in their judicial functions, 58; judicial authorjty when there is no minister to a particular country, 45,58 .

Secretary of State, British, relation to foreign jurisdiction, 70 .

Secretary of State v. Charlesworth Pilling Co., 128 note 2.

Servia, treaty with, 182-3; relinquisiment of jurisdiction in, 182-3; relations with Turkey, 190; relinquishment of jurjsdiction in Turkes, 194-5.

Set-off, allowable in mixed cases, 161; but not against an oriental government, 161.

Settlements, Foreign, 3, 73, 163-76.

Seward, G. F.. issue of regulations of 1863 for China, 54; opinion on legality of allowing associates to separate during a trial. 102; propositions at conference of $\mathbf{1 8 7 9}$ is to improvement of consular jurisdiction adopted, 159-60; Shanghai municipal regulations, 168 note 2.

Shanghai, foreign municipality at, 165-70: growth of the city, 16\%, 170 note 1 ; origin of the municipality, $16-8$; land regulations of 1854 . $157-8 ;$ of 1806 . 168-70; analysis of the regulations of $1866, \quad 169-70$; the legulations of legulations, 170; Chinese or mixed court in, 17s: neutrality of $17,174-5$; British court of appeal at, 72 .

Sheppard, E. T., on obligations of foreigners under the law of Japan, 99 note 1.

Ships, jurisdiction of, in oriental ports, 43: sale of, during war of 1855 in China, 101.

Siam. treaties of 18.93 and 15.56 with the United States. 38: privileges of missionalies in, 125 ; arbitration of the Cheek clain against, 148 note 1,162 ; recodification of laws of, 193.

Smuggling, penalties for. 138 .

Smyrna, early rights of citizens of Genoa in. 4; Messrs. Rhind and offiey at, 21, 22; rights of a diagonian at, st note 1; effect on nationality, of prolonged residence in, 91.

Sovereignty, growth of territorial conception of, $60-7$; oriental, conceptions of, 17-8.

Spain, early reciprocity of jurisdictinnal privileges with Turkey and Tripoli. 1s.

Spheres of influence, native jurisdiction in, 176-7, 180-2.

Spooner. Senator. inprovement of consular jurisdiction, 7

Spies. trial of Japanese at Shanghai, 174-6.

State Dapartment, see Department of State.
Steamer Spark v. Lee Choi Chum, 63

Straits Settlements, British court of appeal at, 72

Straus, O., protection of privileges of American Jews in Turkey, $80-1$; maintenance of the privileges of missionary schools, 113; and of the missionary book trade, 114-5; customs franchise for mission schools continued, 136; indemnities obtained for property destroyed during Armenian disturbances. 150 .

Stupp, In re, cited, 64 note 2.

Succession to real property, 96-7.

Suleiman, Sultan, capitulations of $1535,8$.

Sultans, early adulation of, 6-7,

Summons, service of, 50, 103-4. See the Appendix IV-2, Consular Court Regulations, China.

Supa case at Shanghai, 172-4

Swiss citizens, friendly offices toward, in the Levant, $8 \$-9,89$ note 1 .

Tarsus, disturbances at, in 1895 , 112

Taxation, 134-40; customs in Turkey, 13i-5; internal taxes in Tur key, 135-7; on alcohol, 135; on petroleum, 135-6; exemption of materials for schools, 136; schools, 13b; real estate, 136; on absentees, 135; Imperial Maritime Customs of China, 137 ; customs rules of 1868 and $1902,157-8$ the inland tax, likin. 138-40; abolition of likin, 139-40; of manufactures, 140 .

Tazaymon v. Twombly, 63 .

Telegraph Company, Danish Great Northern, in China, 144-5.

Teskerehs, Turkish, $81-2,135$.

Tidjaret, Turkish court, 152-3.

Tientsin, land concessions at, 166, 167.

Tonga, treaty of 1886 with, 31 ; jurisdiction relinquished in, 1812,182 note 1 .

Tootal's trusts, Re, cited, 92 note 2 Torture of natives in mixed cases disallowed, 161 note 4 .

Travel certificates in China, 82

Treaties, characteristic features of, with oriental governments, 2 constitutionality of foreign jurisdiction, under power to make treaties, 6s; acts named in as indictable offenses, 98, 99; see names of countries.

Treaty ports, see Open ports.

Trespassing. in interior, complaints of, 99.

Trinoli, treaties with, 19-20.

Tsi-Yeng, Prince. negotiation of treaty of 1844 with the United States 32

Tunis, treaty with, 20; French protectorate of. 20, 181: jurisdiction relinquished in, 20, 181 .

Turtey alurogation of extraterritorial treaties sought by, 188-92; arbitration with Greece on continuing extraterritoriality after the war of 1897, 189-90; book trade 
of missionaries in, 114-5; claims against, for indemnities, 150 ; claims against estates of foreigners deceased in, 95; commercial privileges in, 145; disallowance of certain regulations affecting treaty rights, 110-1; exclusion or expulsion of criminal or political offenders, 106-7; tinancial condition of the government, relation of to continuance of extraterritoriality, 147; law of, 153, 191-2; martial law enforced about Constantinople In 1877, 180; mixed cases in, jurlsdiction of, 151-3; Mohammedan law in, 191; nationality, law of, of $1869,79,133$; present administration of justice in, 191-; railways in, 133,141 in, $191-2 ;$ ral property privileges in 199-34: before the rescript of $1867,129-30,133$; nature and origin of the rescript, 129-31; protocol of 1874 with the United States, 131-2: effect of the protocol on jurisdiction, 132-3; rights of expatriated Turks, 133; of Jews in Palestine, 133; right to appeal in realty cases, 134; succession to real property, $96-7$; religjous intolerance in early relations with Europeans, 5-7; religious toleration in modern Turkey, 109-11; residence in the interjor, 111; school regulations, 112-4; taxation, customs, 134-5; internal, 130-6; treaties, with the United States, of 1830, 20-9; of 1862, 29; convention for extradition, 30 ; real estace protocol of $1874,30-1$; convention with Germany of 1890 , 98, 135; convention with Persia of 1875, 18; real estate protocol with France of 1868,130 ; with Great Britaln of 1868, 130; with the United States, 131-3; treaty of 1855 with Greece, 189; relinquishment of jurisdiction in Servia, 194-5.
United States, commerclal privileges in China, policy regarding. 143-5; and in Turkey, 145; Statutes, 41-68; treatles, 19-40.

United States v. Blasingame, cited, 54 note 1 ; v. Dorr, 67 cited, note 1 ; v. Fullert, cited, 54 note 1 . 60,87 note $3 ;$ v. Majd, cited 54 note 1 ; v. Mosby, cited, 56 note 1 ; v. Ross, 50, 60, 65, 87, 103.

Usages, effect of in Turkey, 15- 6 ; and China, 15-6; growth of, in Japan, 15 note 2.

Vacouf lands, 129

Van Dyck, E., eited on Turklsh real property law, 132 note 1 .

Venlce, capitulations of 1199 in favor of, 3 .

Venue, no change of permitted, 61.

Vessels, see Ships.

Villeneuve, negotiation of capitulations of 1740,10 .

War, effect of on, jurisdiction, 179-80.

Weihaiwei, lease of, 176.

Wertheimer, v. Hoeflich, 61.

Wife, nationality by marriage, 79 note $7,94$.

wills, $95-7$.

Winn v. Hill, 61, 62

Witnesses, compulsory attendance of, see the Appendix, Consular Court Regulations.

Women, nationality of married, $79,94$.

Yangtse, regulations for navigation of, 141 .

Yassakdjis, 84-5.

Yenomoto Rukubie v. Pacific Mall Steamship Co., 63 note 3 .

Zanzibar, treaty of 1886 with, 20 protectorates of portions of, $\$ 0$, 181; relinquishment of jurisdiction in, $20,181$.

Zimmi, 129 






University of California

SOUTHERN REGIONAL LIBRARY FACILITY

305 De Neve Drive - Parking Lot 17 - Box 951388

LOS ANGELES, CALIFORNIA 90095-1388

Return this material to the library from which it was borrowed.

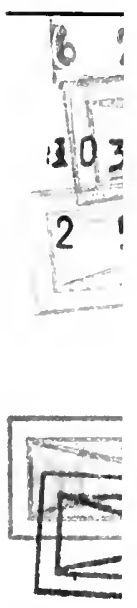

Series 9482 


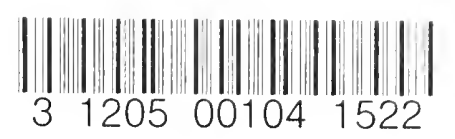

es

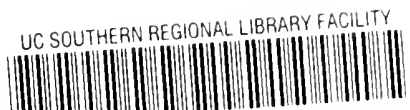

AA 0007906316 


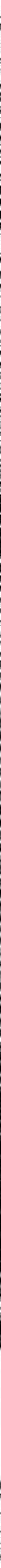

